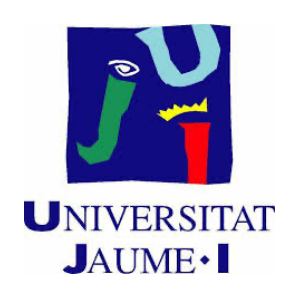

Programa de Doctorado en Estudios Internacionales en Paz, Conflictos y Desarrollo

Escola de Doctorat de la Universitat Jaume I

\title{
Integrating Love in Peace and International Studies
}

Memoria presentada por Egidio Alcides de Bustamante Azevedo para optar al grado de doctor por la Universitat Jaume I

\begin{tabular}{l|l|}
\hline Doctorando: \\
Egidio Alcides de Bustamante Azevedo
\end{tabular}

Castelló de la Plana, Febrero de 2021. 


\section{Financiación recibida}

Esta tesis ha contado con una ayuda para estancias de investigación

(doctorado internacional) ofrecida por la Escuela de Doctorado de la Universitat Jaume I en 2016. 


\section{Dedication}

To my parents, Egidio and Marcia; to my sisters Mariana and Livia; to my nephew and niece Luca and Melina; and to my beloved partner Marc. 


\section{Acknowledgements}

The funny thing about acknowledgements is that in it we generally try to single out special people. But, particularly in the case of this thesis, which tries to build bridges with alterity and even starts questioning the very possibility of separation and distance, I wonder if it makes sense to single people out. There truly are so many people, times and places I want to acknowledge that it might be impossible to do so appropriately. Still, I will try to name a few, knowing many others also rightfully deserve to appear here and may end up not doing so. I ask them their pardon for my limited memory. Well, here it goes:

A thesis is never finished, it gets interrupted, and it has its own time - some people say. The writing of this thesis took an incredibly long time, and it took me a great amount of perseverance to finish it the way it deserves. However, my parents, my sisters and my partner always offered unconditional support throughout this process. Once again, Obrigado pai, mãe, Mari, Li y muchas gracias Marc, mi amor, por todo.

Despite all their support... I still stumbled. Whenever this happened, some truly special people were there to help me: my supervisor Norbert Koppensteiner (extending it to his partner Josefina Echavarría); my dear colleague-friends Alberto Gomes, Jenny Murphy, Jenny Jang, Carlos, Kevin and Magda - with whom I had many research related chats and work experience together; and also, Vittorio, Amanda, Joana, Taís, Gabi, Juliana and the "Pucdevils" simply by hearing me and accompanying me as friends.

I also cannot forget to thank the guidance of Teresa Cunha in Coimbra and my colleagues there; and also my colleagues Adela and Sofia at UJI's Peace Master. 


\section{Resumen}

Esta tesis doctoral busca profundizar la idea del amor y su relevancia en y para los estudios internacionales de paz, y las consecuencias de su integración en la docencia e investigación de Estudios de Paz y Conflictos, Relaciones Internacionales, Desarrollo y Derechos Humanos.

Para tanto, utiliza una metodología trans-racional que abarca, además de una reflexión crítica sobre los estudios internacionales de paz, también aspectos intersubjetivos en la relación del investigador-docente con su tema de estudio y sus colegas/alumnado.

La tesis empieza con una definición preliminar del amor y como el tema ha sido tratado en la investigación para la paz, para luego hacer un análisis de la producción teórica de las Relaciones Internacionales, del Desarrollo y de los Derechos Humanos, llegando tres aspectos claves del amor: apertura, consciencia y presencia. Finalmente, aborda la integración del amor en la investigación-docencia a partir de estos tres aspectos.

Esta tesis termina señalando que la integración del amor en los estudios de paz evidencia la importancia de la dimensión humana en esta área de estudio, ampliando la epistemología de la paz y yendo más allá del mero acopio de conocimientos, de manera que acerque los estudios de paz a una experiencia de vida en lugar de una mera área de investigación. 


\section{Abstract}

This doctoral thesis seeks to deepen the idea of love and its relevance in and for international studies in peace, and the consequences of its integration in the teaching and research of Peace and Conflict Studies, International Relations, Development and Human Rights.

The research was carried out with a trans-rational methodology that includes, in addition to a critical reflection on international peace studies, also intersubjective aspects emerging from the relationship of the teacher-researcher with their subject of study and her colleagues / students.

The thesis begins with a preliminary definition of love and how it has been addressed in peace research. It continues with an analysis of the theoretical production of International Relations, Development and Human Rights, culminating in three key aspects of love: openness, awareness and presence. Then it addresses the integration of love in research-teaching based on these three aspects.

This thesis ends thus making the point that integrating love in peace studies evidences the importance of the human dimension in this area of study, enlarging the epistemology of peace and going beyond the mere gathering of knowledge, in a way that makes peace studies closer to a life experience rather than a research area. 


\section{List of Abbreviations}

CEDAW - Convention on the Elimination of All Forms of Discrimination against

Women

CICA - Central America Indigenous Council

ECOSOC - Economic and Social Council

GDP - Gross Domestic Product

HR - Human Rights

IR - International Relations

IS - International Studies

LTG - Limits to Growth

MDGs - Millennium Development Goals

NVC - Non-Violent Communication

SAPs - Structural Adjustment Policies

TCI - Theme-Centered Interaction

UDHR - Universal Declaration of Human Rights

UN - United Nations

UNDP - United Nations Development Program

UNESCO - United Nations Educational, Scientific and Cultural Organization

WGIP - Working Group on Indigenous Populations 


\section{List of Figures}

Figure 1: Weil's Non-Fragmentary Vision

Figure 2: The four-factor model of Theme Centered Interaction 


\section{Table of Contents:}

GENERAL INTRODUCTION..........................................................................................

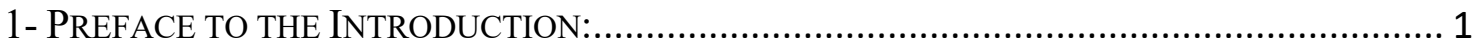

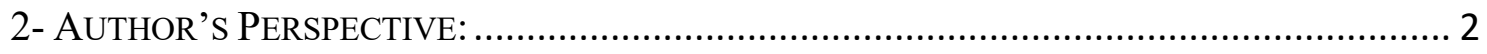

3- THESIS TOPIC:

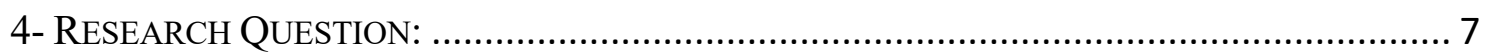

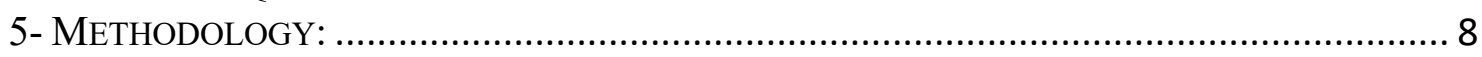

6- RESEARCH DeSIGN AND STRUCTURE OF THE THESIS: ................................................ 13

PART I: LOVE AND LOVE IN PEACE STUDIES ................................................15

InTRODUCTION TO PART I- Love AND Love IN PEACE STUDIES:................................... 15

CHAPTER 1- A WORKING DEFINITION ON LOVE: ........................................17

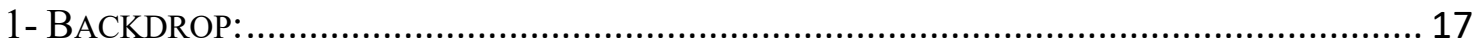

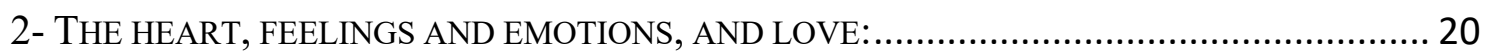

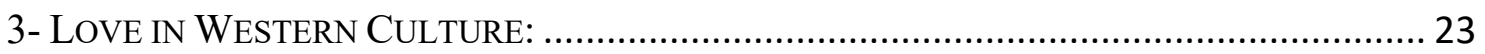

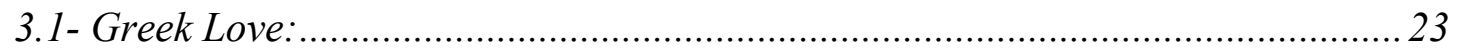

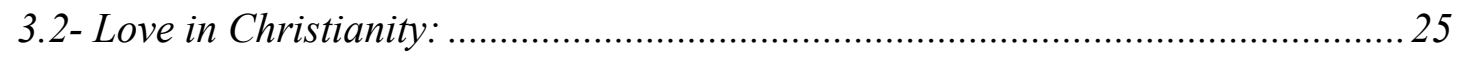

3.3- The Troubadours, Courtly Love and Romanticism: .........................................2 27

3.4- Love in Modernity, Romanticism and Capitalism: ............................................... 29

3.5- Love as Intimacy and Sexuality, and Queer Love: .............................................. 33

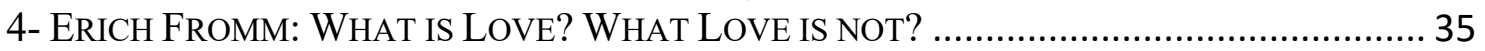

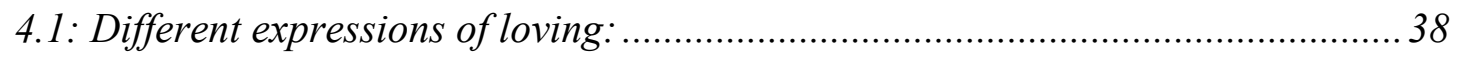

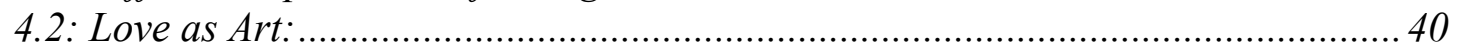

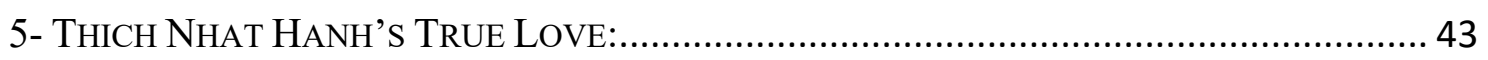

6- ABRAHAM MASLOW: EXPLORING HUMAN POTENTIAL FOR LOVE: ............................ 45

7- CARL ROGERS: THE SHAPE LOVE TAKES IN PRACTICE: ............................................... 48

8- MARTIN BUBER'S PHILOSOPHY OF ENCOUNTER AND DIALOGUE: ................................ 52

9- FREIRE, HOOKS, AND ANZALDÚA: POLITICS INFORMED BY LOVE:.................................. 54

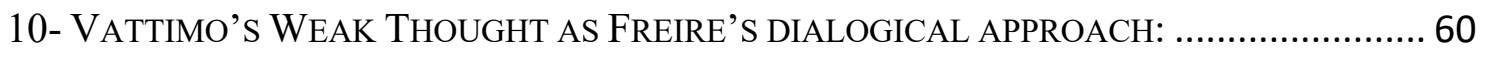

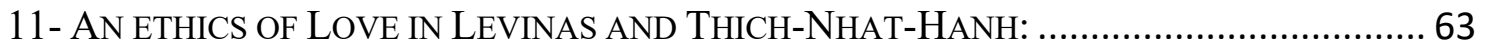

12- EXPRESSING LOVE THROUGH ROSENBERG'S NON-VIOLENT COMMUNICATION: ........ 65

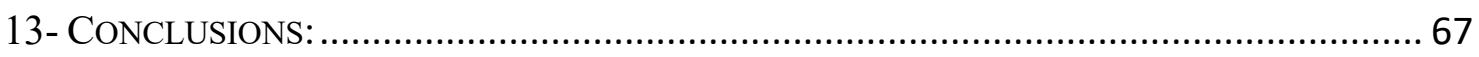

CHAPTER 2- LOVE IN PEACE STUDIES: ..............................................................71

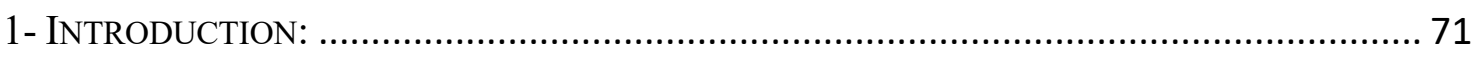

2- Johan Galtung: Blueprints for (love in) Peace Studies:................................. 72

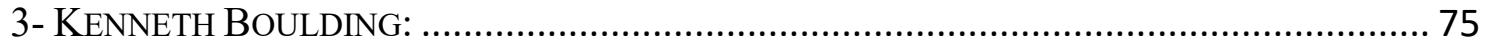

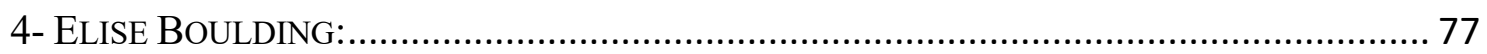

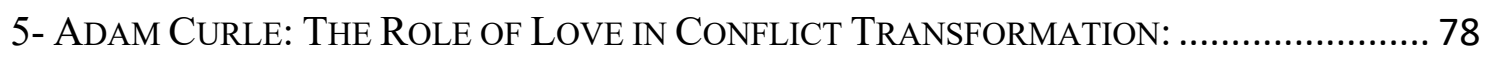

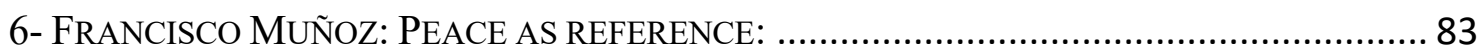

7- VICENT MARTÍNEZ GUZMAN: THE PHILOSOPHICAL BACKBONE OF PEACES: ................ 87

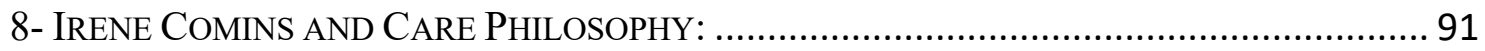

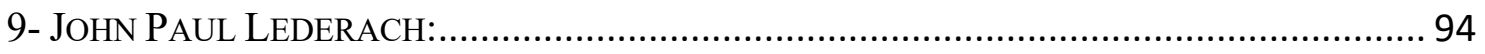




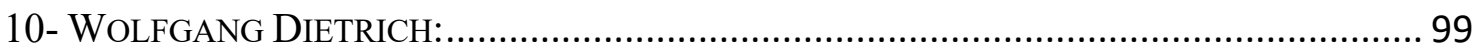

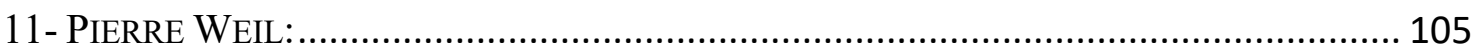

12- FINAL CONSIDERATIONS ON LOVE IN PEACE STUDIES: ...................................... 110

CONCLUSIONS TO PART I - LOVE AND LOVE IN PEACE STUDIES: ............ 113

PART II: LOVE AND THE HEIRLOOM OF INTERNATIONAL STUDIES FOR PEACE STUDIES ......................................................................................................... 116

InTRODUCTION to PART II- THE HEIRlOOM OF INTERNATIONAL STUdieS FOR PEACE

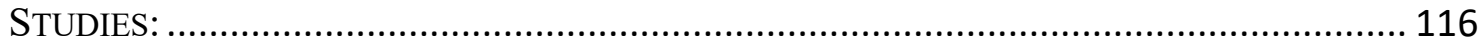

CHAPTER 3- LOVE IN INTERNATIONAL RELATIONS:..................................... 121

1- PRELIMINARY CONSIDERATIONS ON INTERNATIONAL RELATIONS: ........................... 121

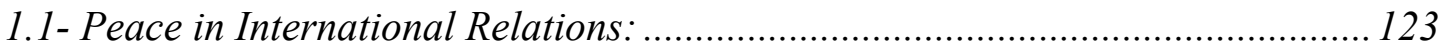

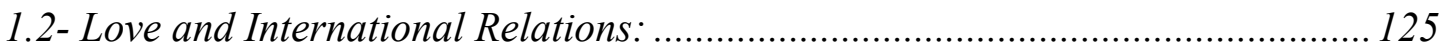

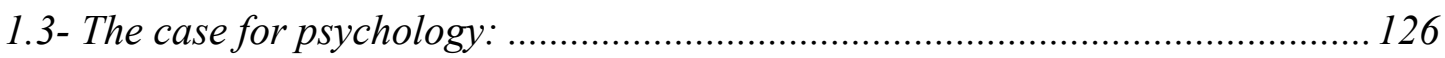

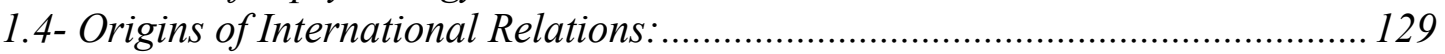

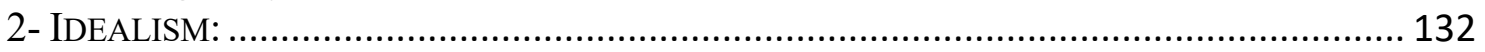

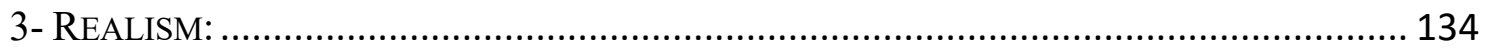

4- From REALISM TO BEHAVIORISM AND THE ENGLISH SCHOOL CRITIQUE: ................ 139

5- THE INFLUENCE OF POLITICAL ECONOMY IN IR: (NEO-)LIBERALISM, NEOREALISM AND

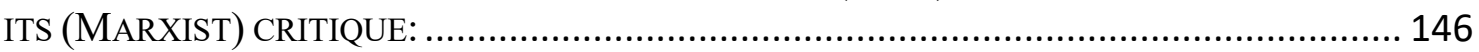

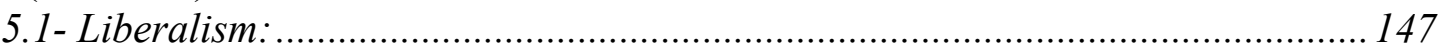

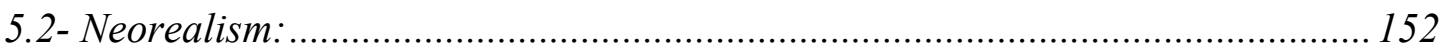

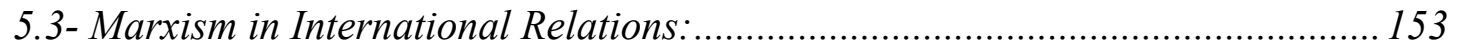

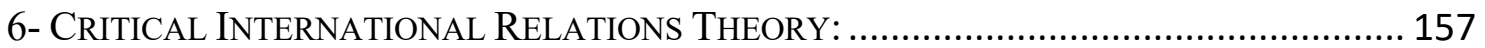

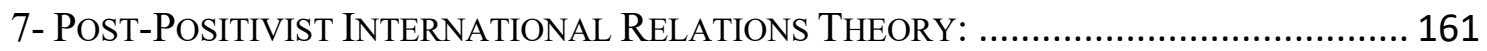

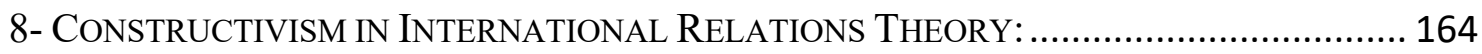

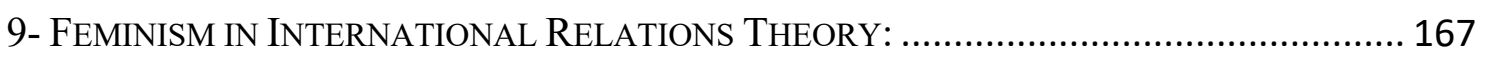

10- POSTCOLONIAL INTERNATIONAL RELATIONS THEORY: ......................................... 170

11- FINAL CONSIDERATIONS ON LOVE IN INTERNATIONAL RELATIONS: ....................... 174

CHAPTER 4 - LOVE AND THE DEVELOPMENT DISCOURSE:....................... 177

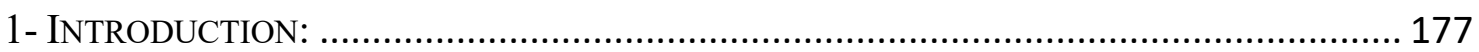

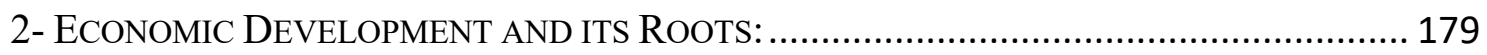

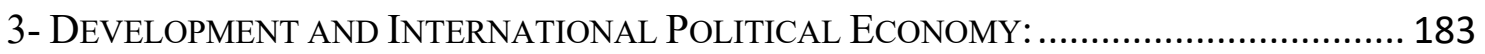

3.1- Development and Keynesian Institutionalism/Paternalism:.......................... 183

3.2- Development and the Liberal Reaction: ...................................................... 185

4- DEVELOPMENT IN THE PERSPECTIVE OF DEPENDENCY AND SYSTEMS THEORY: ....... 187

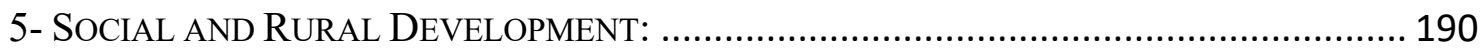

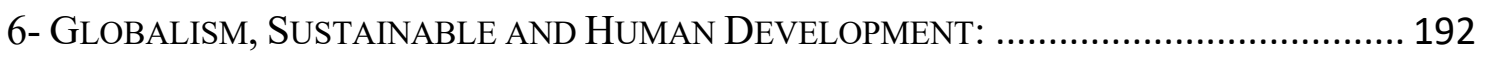

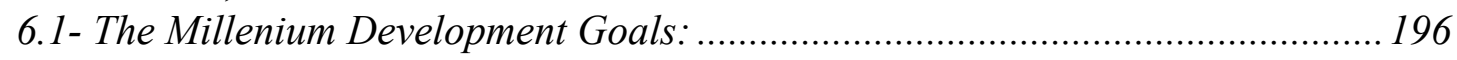

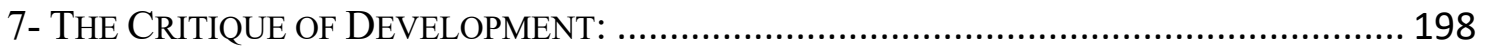

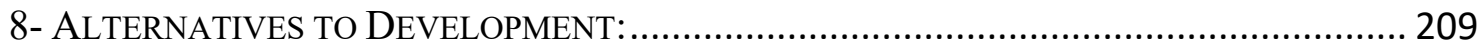

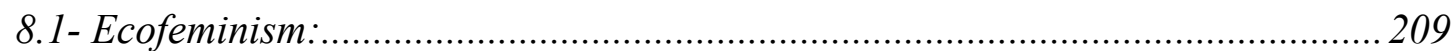

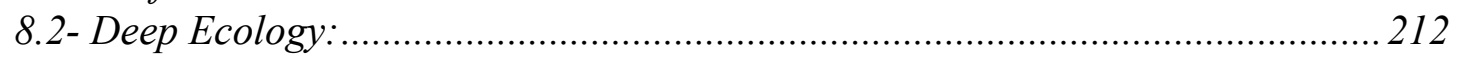

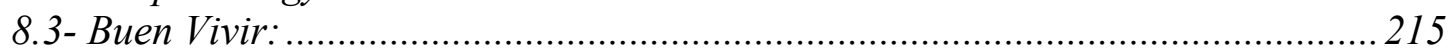

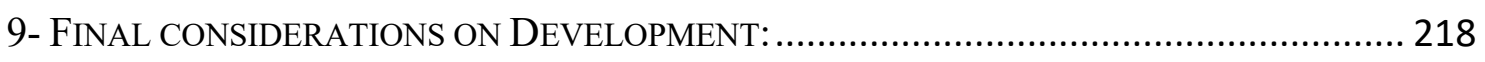

CHAPTER 5- LOVE AND INTERNATIONAL HUMAN RIGHTS: .......................221 
1- INTRODUCTION:

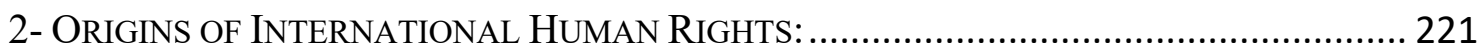

3- ENFORCEMENT AND FORERUNNERS OF INTERNATIONAL HUMAN RIGHTS: ............... 228

4- CRITIQUES TO INTERNATIONAL HUMAN RIGHTS AND REACTIONS: .......................... 233

4.1 - Universal Human Rights?: ........................................................................... 234

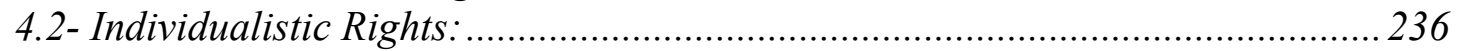

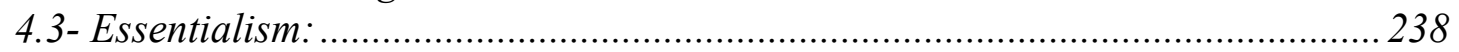

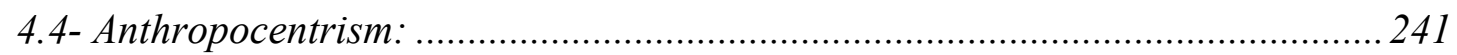

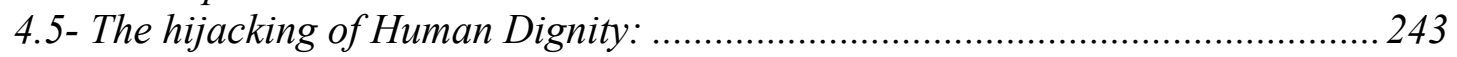

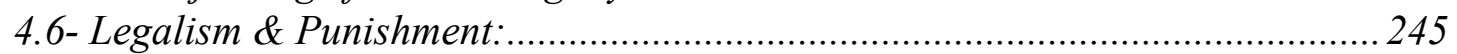

4.7- Human Rights or Men's Rights? A Feminist Critique:.................................... 246

4.8- Ubuntu/Hunhu as Human Rights Critique: ....................................................... 248

5- FINAL REFLECTIONS ON LOVE AND HuMAN RIGHTS: .......................................... 250

CONCLUSIONS TO PART II- REGARDING LOVE AND THE HEIRLOOM OF

INTERNATIONAL STUDIES FOR PEACE STUDIES: ........................................254

PART III: TOWARDS A PEACE SCHOLARSHIP THAT INCLUDES ONE'S

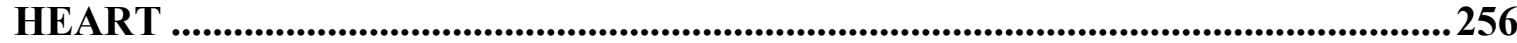

INTRODUCTION TO PART III- TOWARDS A PEACE SCHOLARSHIP THAT INCLUDES ONE'S

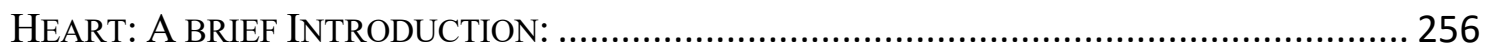

CHAPTER 6 - PEACE STUDIES WITH ONE'S HEART: ....................................258

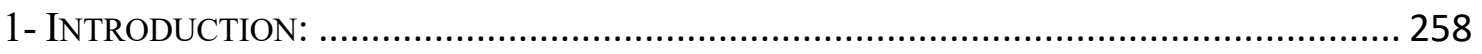

2- OPENNESS THROUGH NAEEM INAYATULLAH IN AUTOBIOGRAPHICAL IR: ................. 261

2.1- Conceptualizing Openness: ..................................................................... 263

3- AWARENESS IN HATHAWAY AND BOFF'S ECOLOGICAL CONSCIOUSNESS IN THE TAO OF

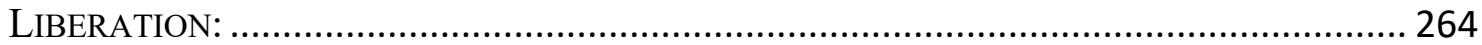

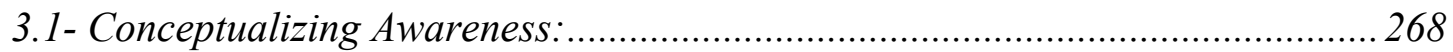

4- Presence through Ubuntu/Hunhu as Human Rights Critique: ...................... 268

4.1- Conceptualizing Presence: ........................................................................... 271

5- Theme-Centered InTERACTION: OpenNeSs, AwARENESS \& PRESENCE INTEGRATED

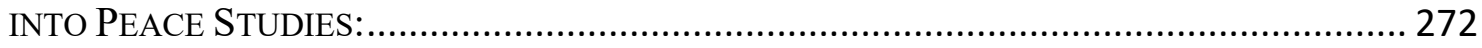

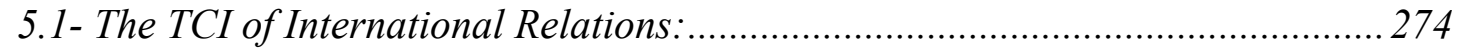

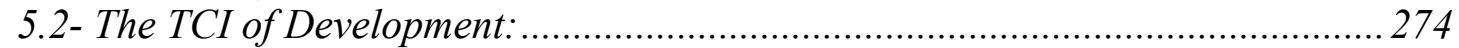

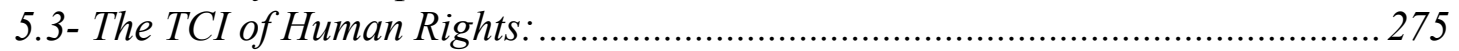

5.4- The TCI of Openness, Awareness and Presence: ............................................... 275

6- OutComes of InTEgrating OpenNess, AwARENESS AND PRESENCE INTO PEACE

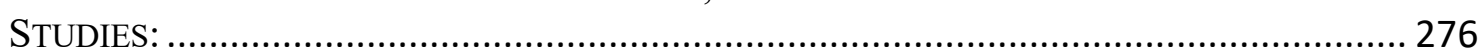

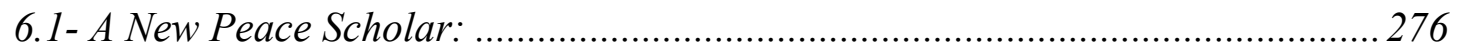

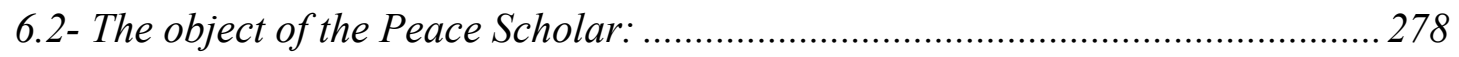

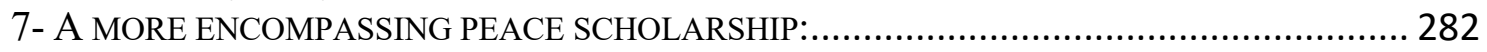

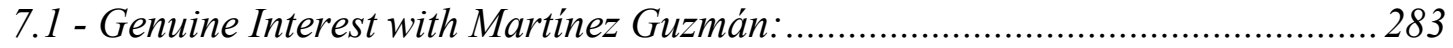

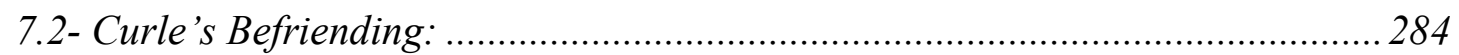

7.3 - Comin's Care Ethics into a Caring Teaching: ................................................. 286

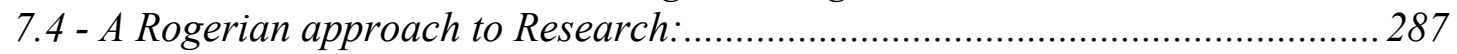

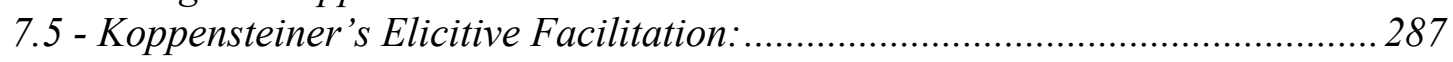

7.6 - Lederach's Three Qualities from Web-Watching: ......................................... 289

8- Final Considerations On LOVE AND PEACE STUdies: ........................................ 291 


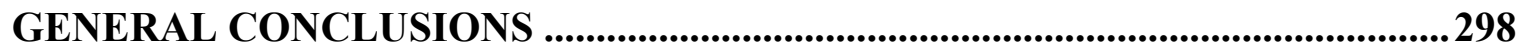

CONCLUSIONES GENERALES (EN CASTELLANO):...........................................308

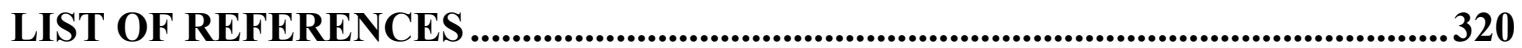




\section{General Introduction}

The time has come for humanity not only to begin to understand the nature, forms, and how and why of love, but also to endeavor to design more efficient techniques of its production. (Pitirin Sorokin: 1954, p.37)

\section{1-Preface to the Introduction:}

Is there room to talk about love within the social sciences? In my bachelor's degree in International Studies, which is commonly situated within social sciences, there certainly was no room to include such a subjective matter. In the natural sciences, modeled after Cartesian objectivity, love is definitely not a matter for academic discussion. Thus, premised on the same Cartesian mindset, it would only be reasonable for love to be excluded as a relevant matter for the social sciences. Yet, I contend that love is not something that one can simply ignore or take out of oneself while diligently reasoning out and conducting any form of research, particularly when it comes to research, teaching and being concerned over human beings and life in general. Love spills over everything one does. If I understand love as commitment and service for humankind, and if the social sciences represent an effort to learn about social relations in order to critically and transformatively engage with people, communities, and societies, then love is a fundamental aspect of any social-sciences endeavor, and it is all too often overlooked.

A more recent field area springing from International Studies, Peace Studies takes to heart the realizations of the limits of objective and empirical reasoning. The discipline poses new questions over how we relate as humans, by twisting what is traditionally 
considered "pure" (social) sciences - for instance through Martínez Guzmán transmodern approach (Martínez Guzmán: 2005) and other researchers to be discussed in this thesis. Yet, even Peace Studies has not dealt sufficiently with the topic of love. One of the consequences of that is the lack of a proper conceptualization or systematic reflection of love, but also of its role in Peace Studies and how it transforms the discipline. Therefore, the following thesis aims at critically reflecting upon the onto-epistemology of Peace Studies and of International Studies (as its original field) once a perspective of love is integrated into peace. In this thesis, following Martínez Guzmán, love is understood as a transmodern and potential faculty of human beings, especially relevant for the matters and concerns of peace.

In the following introductory pages, I present my author's perspective, importantly situating myself in relation to the research topic, while simultaneously highlighting a broadened understanding of a scientific research endeavour. Directly after, I detail a consolidated thesis topic and my research question, discuss the applied methodology, and end with the overall structure of this work.

\section{2- Author's Perspective:}

In my MA thesis I wrote a more descriptive author's perspective, based on larger aspects of my life which brough me to peace studies. For this doctoral thesis, however, I would like to be somewhat stricter, and raise a few representative points of why I came to engage with the topic of love in Peace and in International Studies.

I was raised in a nurturing environment, in which there effectively was plenty of love - expressed through tenderness, affection, caring and unconditional support. I grew up in close connection to relatives, often going to my grandparent's farm. This gave me the opportunity to grow in an environment that allowed me to be sensitive to and appreciate 
life in its many forms. As a child I was raised in my family's spiritual practice, Umbanda, which combines Allan Kardec's Spiritism, African Candomblé and the spirituality of indigenous peoples within the region of Rio de Janeiro., I came to know that I am "guided" by an Orisha ${ }^{1}$ named Oxum, which in its syncretism represents nurturing love and aesthetics within African Candomblé, rivers and cascades for indigenous groups in Brazil and, within Catholicism, is associated with the figure of the Immaculate Conception of Mary, which stands for unconditional love.

Although my experience could be considered an ideal environment for any child to grow up in, outside of it, I was severely bullied when I publicly demonstrated the sensitivity, affection and care reproduced of that with which I was raised. Even if being tender to, caring for, and being genuinely interested in others was (is) a main drive of mine, painfully I realized that in a patriarchal society such as the Brazilian one, tenderness, affection and caring are considered feminine traits to be discarded if you are a cis-gender man.

Growing up in a country considered to be one of the most unequal places in the world, being confronted with shocking and unacceptable misery, has also always been a big personal issue: how come people lacking the means to survive, thus suffering tremendously, did not receive the proper care they deserve as human beings? To care about people also means caring about their livelihoods, well-being and means to thrive, not merely to survive. As such, social justice has always been a concern of mine and an important aspect of love.

One aspect of growing up in a nurturing environment is that it provided me with the trust to venture beyond it. As such, I was encouraged to be interested in and curious about

${ }^{1}$ Orisha comes from Yoruba language - the Yorubas were a considerable portion of enslaved Africans that forcefully migrated to Brazil. 
different cultures and different ways of living. This experience, combined with the contextual moment Brazil underwent in the 90s (opening up after over 30 years of dictatorship), led me to study International Relations, as a way to get to know different cultures and find resonances with my life experience and answers to the struggles I saw in my home country. However, even in my studies, I got disappointed with an area marked by cynical approaches to international (power) politics, with people competing for resources, power and control - even if well-meaning and working towards social justice. There was no space to talk about love in International Relations. Meanwhile, there has always been a certain peace discourse that called my attention, and led me to peace studies.

Perhaps I am a latecomer to the 60 s, when the motto of peace and love became popular and was associated with the hippie movement. Perhaps the reason for such scholarly interest of mine resides in the fact that the potential of peace and love has not been taken seriously. My own drive in peace studies has been to evidence the importance of creating a caring and nurturing (a loving) environment and attitude, which I consider fundamental aspect of a peace scholarship. The primary reason for that is the transformation and alleviation of human suffering.

\section{3- Thesis Topic:}

I was educated in International Relations, a discipline conceived in Europe after the devastating impacts of World War I on European people. The discipline arose from a European idealist belief that men could be good, civilized and prevent war if they organized themselves into well functioning sovereign states. International Relations was up to that point a discipline of politics on an international level aiming at the prevention of conflicts. However, with the éclat of World War II, the discipline soon changed from how the world should be (devoid of conflicts), to what it "really was", giving rise to realist assumptions 
of war and violence as the natural state of the international environment. Parallel to such academic debate, European Nation States still held colonial control in "the global south", and the concern over statehood and its derivative conflicts excluded the concern over those conflicts derived from colonial subjugation.

The discipline of IR formally came to be through the debate between how different cultures, organized as Nation-States, should interact and how they actually interacted with each other in the "international arena". What sprung out of it was a series of theoretical and abstract intepretations and debates over the behaviour and functioning of Nation-States. Of course, the IR debate evolved and made bridges with other disciplines. It was, for instance, affected by the post-modern deconstructionist view that brought in the question of the limits of the nation-state, the limits of the discipline itself and of its own cultural context and mindset - such as the challenge to modern objectivity.

Despite IR's focus on Nation-States and politics, it is also undeniable that political economy and development policies came to have a major role in the XXth century. Development grew out of a scarcity approach to economics which is, in itself a parallel (but significant) influence to international relations (relations between countries), as economics play a huge role in the contemporary international system; some argue that it became the most relevant aspect of international relations, able to curb or induce conflict and violence. In this sense, the political economy debate of the XX century gained particular relevance for international relations, especially the 'development' approach of enlarging a nations' economic capabilities in order to offer its citizens an avenue out of poverty, since poverty was considered to be a trigger for conflict and violence. Yet, the development discourse started to be questioned due to the impacts it has thus far caused on the environment and on other living beings and whether treating poverty has not become a problem in itself. 
At the same time that the international domain has been concerned with the prevention of war through IR theory, and with the erradication of poverty through development policies and discourses, it has also been strongly influenced by a Law/Rights debate, particularly the Human Rights debate, reminding the discipline of International Relations that its original intent was to safeguard human life by devising political mechanisms to prevent war and suffering from lacking economical means. Thus, and not surprisingly, the debate on Human Rights also came to dominate the international agenda, especially after the Human Rights Charter of the United Nations called for preventive mechanisms to war and violence. Who would be against Human Rights? Ever since, Human Rights (HR) became a powerful discourse and a grand concern within International Studies.

These 3 topics/disciplines (International Relations, Development and Human Rights) have thus formed a comprehensive perspective into the international domain; furthermore, in academia, their combination has been commonly referred to as International Studies. Their contents and approaches were hallmarks in my graduate level education, and helped me attain a broader sense of the world, despite the fact that the important aspect of love, which influenced most of my way of relating, was pushed aside.

Meanwhile, Peace Studies emerged as a critique to International Studies, understanding the limitations of such disciplines when it came to peace. Therefore, it departed from the topics traditionally discussed with International Studies, and opened up different perspectives and approaches. To briefly underscore two peace perspectives which acknowledge love as fundamental aspect of peace, I can mention that:

- Filosofia para hacer las paces by Vicent Martínez Guzmán (2005) paved the way for introducing intersubjectivity into peace and conflict studies, affirming that humans are also capable of loving and not only of waging war; and 
- Adam Curle, the founder of the first peace studies program in Europe, who dedicated an entire book on love as a fundamental aspect of peace, titled The Fragile Voice of Love (2006).

\section{4- Research Question:}

In my personal experience, the education I received in International Relations and the world around me shattered the value of love and an organic connection between heart and mind - as a balanced interplay between a sharp intellect and compassion. As such, International Studies privileged the cognitive aspect of intellectual assimilation of discourses and subdued a consideration of it from the standpoint of love.

Bringing this "heart" dimension of being back into my scholarship is, therefore, important not only to address a previously hampered drive of mine, but also to engage with the world. By integrating love as an approach to human relations within peace studies, I can cast a gaze over the discourses of International Studies and provide a frame with which these discourses are considered within peace studies, which can be meaningful for this discipline if it intends to remain faithful to human experience.

I Share my own story and this renewed gaze into International Studies in order to offer others the opportunity to reflect upon their own trajectories and also the way they have engaged with their studies. I am especially speaking to those who are currently taking a similar path to my own, studying International Relations, Development or Human Rights. However, I place emphasis on the effort of eliciting a peaceful, loving and compassionate outlook and engagement with the world. It is an invitation for people to consciously consider how they make meaning of human relations.

My PhD Project proposes re-approaching the disciplines and discourses of International Studies, in the guise of International Relations, Human Rights and 
Development from a heart's perspective, from love. My research seeks to address and answer the following questions:

How does love transform the discourses of International Studies (IS - Development, Human Rights and International Relations) taken into Peace Studies? How? Can I find a resonance with critiques of/within these disciplines? Or can I find resonance with 'alternatives' to them? Which panorama unfolds for a peace scholarship after/from these transformations?

Peace Studies came to be a field in itself after the realization of how the general area of international studies became stale and lacking an actual peace focus. Surprisingly, though, no thorough work has been conducted on the relationship between peace studies and love thus far - perhaps because it may echo the discredited slogan of the hippie movement. A careful analysis of this relationship, however, will evidence its relevance. After all, if I am to be rigorous, Adam Curle's seminal peace scholarship pointed to the importance of integrating love within peace work, and other peace authors have only "en passant" discussed love as an aspect of peace and international studies.

\section{5- Methodology:}

After the above-mentioned considerations on what compels me to pursue such a writing endeavor, a necessary step is to reflect on the methodology most suitable for it.

Discourse analysis could well work as method to give evidence to which rationale Peace Studies inherit from International Studies. After all, this thesis does provide an analysis of how International Relations, Development and Human Rights conform disciplines and discourses that limit how one sees the world and derives thereof performative practices, which in turn affect one's social relations and their entire system. A clear example of this is how International Relations discipline reifies and privileges the abstract idea(l) of the Nation-State and how such a discourse becomes very real and poses 
very concrete implications on human empathy and bonding beyond the borders of such states. Development discourse also works in a similar fashion by interpreting poverty as lifestyles that do not conform to a Western-capitalist canon on private poverty and call for programs to homogenize diversity into a Western-capitalist lifestyle. Embedded in Human Rights discourse is the normative notion of a substantive ontology that views people as single entities that must lawfully interact, not out of genuine intention or, for instance, compassion, but by fear of punishment for not respecting those laws.

In this work, however, my intent does not remain in nor originates from analysing what Peace Studies may reproduce or reject from International Studies. Works like these have been extensively done. My purpose is not to merely analyse the world and ideas about the world alone. My purpose is to relationally engage with the authors of Peace Studies and International Studies as people fashioning and relating to their worlds, through their own texts. In this way I am connecting with them in a certain way, making meaning of what I also feel, or learn through my heart. Thus, I am more concerned with a mode of researching and with a mode of living that is actively seeking ways to connect with human beings, and that already stretches beyond discourse analysis in terms of method. In sum, I am using elements of discourse analysis but I am broadening and stretching what has traditionally been understood as discourse analysis, towards a more heart-centered dicourse analysis that privileges all senses, not just the cognitiev one. Especially because this attitude of love, of knowing from the heart, informs and motivates my cognition and use of reason, and since I consider peace as phenomena that involves human beings in all our faculties, the methodology that most suits this work, and therefore the one chosen, is a transrational methodology. 
The transrational methodology encompasses not only the possibility of rationalcognitive and critical reflection on any given topic, but it also gives space to analyze the inter-subjective aspects related to the researcher engaging with the topic of study.

...what I am looking for is an affirmative methodology and practice of research that includes and balances the necessary critical positioning as regards the researcher and her engagement with the topic and research participants. Conceived in this manner, research becomes experiential. In doing so I am carried by the conviction that research can be much more than the dry and distanced gathering of knowledge or the critical examination of one's own biases and imbalances. I personally find research to be at its most inspiring when (...) the heart is empathically open to the investigation and to research participants. (Koppensteiner: 2018: p.60)

Following Koppensteiner, the research carried out in this work is not reduced to the mere qualitative analysis of data, but requires an intersubjective, empathic, and open relation, not only to my research topic, the heirloom of International Studies to Peace Studies, but above all to the human beings behind those ideas and intepretations of the world, especially the authors of the texts themselves. This requires making the humans behind the text visible in their biographies beyond their written ideas, making this process a human meeting, although not one of flesh and bone due to time, geographical and financial limitations. Still, this approach opens a significant space for the transformation not only of the discursive practices and mindset of International Studies brought into Peace Studies but also to open space for my own transformation as author in relation to my field work. In so doing, I generate the possibility of transformative resonances over my readers/public. For the sake of brevity, I present the underlying considerations of this methodological approach here:

-As an ontological perspective, transrational cosmovisions proceed from the underlying unity of all of existence. The microcosm of the human being and the macrocosm reflect each other.

-Epistemologically both (post)modern rationality and experiential, (transpersonal) ways of knowing are integrated as valid sources of knowledge. 
-Ethical positions are premised on the researcher locating herself as author. As there are no objective, neutral or outside positions it falls on to the researcher to disclose the own stance and approach.

-Self-reflexivity encourages the researcher to re-interrogate continually her own scholarship.

-Transrational research methods integrate the researcher both as a source of information and in her process of transformation. ${ }^{2}$

Considering this work as the integration of a rational-cognitive approach to the content of International Studies brought forth into Peace Studies, and at the same time contemplating a transpersonal approach to knowledge, more particularly understanding love as a source of such transpersonal ways of knowing, it is important to briefly explain how love operates on a transpersonal dimension. In the seventies Carl Rogers' humanistic psychology proposal and his focus on the person already tried to see and empathetically engage with the human being behind discourses and practices. Rogers tried to establish an empathetic relation with them marked by the appreciation and deepest respect for such a life experience.

In an essay on deep empathy, Tobin Hart (2000, p. 253) mentions that when we pay attention to and simply open ourselves to the person and his/her voice that comes to us, the understanding of the other seems to deepen and his/her feelings become very clear, as if one could feel the other's feelings emanating from their words and discourse. Hart also states that very often, these experiences present themselves as the moments in which he felt most human, most compassionate and intimate with the world, in which his heart and wisdom were brought to the surface. In a way, this intimacy worked as if allowing one to experience being the other, and that such experience provokes a shift in consciousness and awareness that opens space for integrating it as knowing and transformation. According to

\footnotetext{
${ }^{2}$ Excerpt from a presentation given by Norbert Koppensteiner on Peace and Peace Research Methodologies in Castellón de la Plana over May 2012 (unpublished).
} 
Hart, such transpersonal experience is very often referred to as a manifestation of love (2000: p.265). It is in this vein that love is explored in this thesis, as a transrational way of knowing from which a discourse analysis of International Studies derives, in order to provide an enriching and transformative approach to these topics and their relation to peace(s).

At this point a clarification on this method might be necessary: to engage with someone in a compassionate and respectful manner, in a loving manner, allows us to , understand and feel what others might experience with this empathic bond. To use a popular expression: "being in someone else's shoes". At the same time, while a person can be in someone else's shoes, one can never totally grasp - understand and experience in its entirety what it is like to be "in someone else's skin". And precisely because of that, this might allow us to engage with someone's conflict with slightly less clouded perspectives and critically reflect on such shared experiences. Of course, it requires a continuous selfevaluation on how one is engaging with others, approaching conflicts and projecting their own.

The question then arises how to establish this compassion bridge in order to derive from it a way of knowing persists. Hart (2000, p. 44-50) mentions how practices of perceiving beauty and meditation welcome and trigger this way of loving/knowing, that he calls inspiration. With that, Hart also mentions that focus, as deliberate intent; trust, as letting go of preconceptions and prejudices; and finally, attention as expansion of awareness, are characteristics that one can harness and develop in order to woo inspiration and love.

Incorporating these practices and bringing it to the research allows for transformation within the field of International Studies, but not through a purely rational and critical perspective-taking on the theories of the study field. Because research is about 
(intersubjectively) lovingly/empathically engaging with the human face behind theories, it acknowledges and respects their path and experience and theoretical reflections and projections of that person but does not take it all in without twisting it towards a different path that might be more in sync with one's own perspective, seeing value in presenting one's own experience as findings.

\section{6- Research Design and Structure of the Thesis:}

Having clarified in the methodology section the way I approach and inquire into International Studies, I may now proceed to the design of the research. In this section, I provide an explanation of how each part and their chapters were structured in this work and my purposes within such a structure.

I divided the thesis in three main parts. Beyond this very introduction, the first part comprises two chapters. In the first chapter, I provide a working definition of love and what love is not, so that I can move onto the second chapter delving into how the topic of love has been approached within peace studies.

The second part of this thesis is divided into three chapters. In this section, I delve into International Studies and the overarching disciplines/discourses of International Relations (IR), Development, and Human Rights. After a brief introduction on International Studies in this second part, I devote the third chapter to a reflection on International Relations, the fourth chapter to a reflection on Development and the fifth chapter to a reflection on Human Rights. Within each of these chapters, I approach each of the theories,

trends, and debates of IR, Development and Human Rights through heart and mind, making explicit how engaging with them from the perspective of love laid out in the first section can transform such perspectives. 
Having completed these steps, I may now proceed to the third and final part of this work, which comprises one last chapter. In the sixth chapter, I provide a reflection on the kind of peace scholarship my research has led me to, and also connect it with the research trends and tendencies currently taking place in the world within Peace Studies and International Studies. Finally, I move towards an overall conclusion of this work and the list of references used. Without further ado, I may now proceed with the next parts. 


\title{
Part I: Love and Love in Peace Studies
}

\begin{abstract}
At the present juncture of human history an increase in our knowledge of the grace of love has become the paramount need of humanity, and an intensive research in this field should take precedence over almost all other studies and research. (Pitirin Sorokin: 1954, p.xii)
\end{abstract}

\section{Introduction to Part I- Love and Love in Peace Studies:}

The combination of the words peace and love stand out as a terrible cliché echoing from the hippie movement in the US in the sixties. Even without the combination of both words, the stereotype of a hippie pacifist has marked the entire enterprise of peace studies until today. In order to steer away from being discredited as a relevant area of study with legitimate concerns, it would be only natural for peace scholars interested in fitting peace studies into the more traditional canon of social sciences - or even academia - to break apart any association of peace studies with being a naïve hippie, and separate the concept of peace from any understanding of love. And yet, to be concerned with peace, and to understand it as a quality that permeates human relations, it is only fair to question whether or not love plays a role into meaningful human relations. If any prejudice should prevent any researcher taking a closer inspection onto the relation between love and peace - in fact, between any two elements at all, even if they seem most absurd - then I can certainly consider such an attitude as unscholarly or filled with prejudice. Evidence might be easily spotted by some, but the quest for arguments that may point to a certain level of evidence that amount to 'facts' remains as the modus operandi of the social sciences To make matters clear: in academia, a proper researcher's attitude should definitely welcome the effort of 
gazing into concepts, ideas and discourses without any form of prejudice or bias, understanding how they tint any research. It is an entirely different question whether research proves to be relevant, useful or interesting to people other than the scholar carrying out his/her/their own research.

With such a perspective in mind, in the first chapter I explore the more common meaning of love in contemporary society in order to establish a working definition of love, making a brief geneology of it in the West (even though I am not approaching only scholars and intellectuals that are of a Western background). In the second chapter, I analyse how peace scholars have understood and dealt with love in their own work in order to highlight common understandings and any meaningful divergences, assessing also its relevance for peace studies itself. 


\title{
Chapter 1- A Working Definition on Love:
}

\author{
Men want to know love and they want to know \\ how to love. There is simply not enough \\ literature speaking directly, intimately, to this \\ need. (hooks, bell. The Will to Change: Men, \\ Masculinity, and Love. Apple Books)
}

\section{1- Backdrop:}

In 2015, the world has seen what has been termed the biggest humanitarian crisis of the XXI century, after thousands of Syrians fled their country heading to safer zones in Europe. Based on the fear of losing their cultural habits after such a massive influx of immigrants and on the fear of "terrorism", the response of some European government officials demonstrated a certain inaptitude or disinterest, and even denial with regards to receiving those immigrants. In 2014, the Australian government published a warning that they would refuse to rescue drowning immigrants who did not hold visas to enter Australia. Also in 2014, and within the borders of Mexico, in Ayotzinapa, police officers killed 41 students who were picketing their government. These are some of the well documented cases of violence out of the many conflicts that affect the world, albeit many others take place without the larger awareness of the public. In the cases that gain a global dimension and audience, the common discourse usually invokes the role of international studies in order to approach the matter of global governance, promising effective responses to the ever-lasting human suffering.

In her more recent conferences, philosopher Judith Butler has been addressing the ethics of non-violence and the imperative of thinking if some bodies, as the constituent of 
a subject's life, still matter. ${ }^{3}$ With this, Butler wishes to discuss on which premises one engages with the world and the lives of the many humans in it: on which premises do people perceive the violence of killing another person as legitimate, or letting another drown, or denying movement into safe zones. Butler argues that behind every action, every political action (understanding politics as the relation between two or more people), there is an ontological and epistemological assumption that needs to be considered if we are to provide an ethical and non-violent response to human beings. Behind the legitimation of those deaths, or even the disregard for them, Butler points that a certain individualism, a sense of unrecognition, a sense of (in)difference and therefore disconnection, blocks us from revering life and respond to those in peril.

Addressing this gap between fellow human beings fostered by individualism, Boaventura de Souza Santos proposes the Epistemologies of the South (2016), invoking the decentering of oneself, one individualized being, towards learning about others, engaging with them, learning from and with them, making a reference to a "Global South" that would counter a substantive ontology. Boaventura's proposition stems from his perceived need of engaging with people more directly affected by the policies created from a mindset marked by an overpowering individualism within (modern) rationality, which has been extended to most parts of the world.

However, Boaventura and Butler's intentions, expressed as moral political imperatives, hardly allow oneself to actually understand the actual, deeper purpose which I perceive in their reflections: to discover, uncover and honor human life in to be of service to them. The problem with a moral framing of Butler and Boaventura's intention is that it ends up also othering people, especially those who do not favor their own understanding of

\footnotetext{
${ }^{3}$ University of Notre Dame, Indiana April 9th, 2015 and Centre de Cultura Contemporánea de Barcelona, November 5th, 2015.
} 
solidarity towards the least favored. Thus, it is of fundamental importance that in their condemning of people's actions they do so without condemning the individuals perfoming those actions, as discrimination hardly is coherent when it comes to call for collective engagement and transformation of suffering. To address this problem, it is fundamental that I am open and willing to engage with and be of service to human beings in the full spectrum of their humanness - leading to a form of relating and of doing politics even with those who may perform the cruelest acts. If I am condemning deliberate violence as a form of relating, then I must not only care about those who have experienced violence and whom I wish to support and see thrive, but I also need to engage with whomever must have inflicted violence in the first place. In order to make sense of how the situation came to be and address its seedbed, I must be careful not to incur myself in the violence of condemning the individuals who might have acted woefully; at the same time, this is certainly not giving people free passes for their actions. It is a delicate balance between not engaging in 'othering' myself, while calling for accountability. This is of paramount importance in times of polarization. For istance, it may be quite displeasing to engage with proponents of ideas akin to facism; it may be extremely important to prevent these ideas from becoming institutionalized practices; but the mere exclusion of people thinking in such way will not be enough to transform them.

To avoid the performative contradiction of condemning violence and in the process being violent myself by condemning individuals who committed acts of violence, I propose to approach the matter making use of my fundamental capability of understanding our human condition, and the desire of transforming human suffering. It is important to tap into my heart and its potential of/for loving, which is also a collective potential as everyone has a heart. I work from this personal stance to the more collective one within the realms with 
which international studies deals. Therefore, this thesis starts with a chapter with a working definition of love.

\section{2- The heart, feelings and emotions, and love:}

In contemporary culture and common knowledge, there exists an undeniable - and problematic - association of love with the heart, and an understanding of love as a form of feeling or an emotion, to the point that the following definitions can be found on the online Merrian-Webster Dictionary: "the emotional or moral as distinguished from the intellectual nature; one's innermost character, feelings, or inclinations", and also "the essential or most vital part of something".

Elisa Kozasa, a psycho-biologist from the Brain Institute of the Albert Einstein Israeli Hospital in São Paulo, Brazil, contends that the popular belief that the heart is the seat of our feelings, emotions, and inclinations is due to the interrelation of the nervous and the cardiovascular systems of human beings. This association gives an illusion that feelings and emotions stem from the heart because the nervous system carries information out of what one perceives and feels from his/her surroundings and memory to the brain. Once these inputs are processed and interpreted, the brain activates an appropriate heart beating frequency to respond to the context in which one finds oneself. But Kozasa notes that these phenomena cannot be reduced to a mere biological aspect of life, as the processing of our feelings and emotions by our brains and bodies can have a significant impact on our lives and end up affecting our subjectivity and the way we relate to fellow human beings. (Conamedic: 2017)

Going further into dismantling the association of the heart with feelings and emotions, it is also important to differentiate emotions from feelings. Feelings in this sense can be regarded as an acute awareness of the present moment and environment, which 
happens regardless of our own consciousness of it, although with work feelings can also be brought to this level. Meanwhile, emotions are the (somewhat deliberate) inner-responses I am predisposed to have while interpreting certain feelings, based on the assumption that accessing personal memory and making associations between similar moments may at times be helpful - which bears good relation to the idea of survival instincts. However, tapping into one's emotional database brings the dangers of misinterpreting present moments by losing sight of the particularity and uniqueness of each situation in which one finds oneself, focusing on previously lived experience and projecting it into the present, reenacting and reliving the past. Since emotions usually tend to be more graspable by consciousness than feelings, with proper attention and practice, it is theoretically possible to gain a certain level of awareness about how I tend to emotionally react to my feelings, which can provide more balanced responses to experience.

From Kozasa's physiological separation of the heart from feelings and emotions, and the further differentiation between feelings and emotions, now it fair to ask if there exists a relation between the heart and love. Kozasa's research points that there is no medical evidence that the human organ which we call heart is the place where one's capability for loving seats. However, the HeartMath Institute in California has been conducting research on the electromagnetic fields generated by the rhythmic activity of the heart, in an effort to empirically prove that the heart might function as a center from which human beings are able to connect with each other and thus feel this connection, associating one's capability to love with sensing and generating electromagnetic fields exchange. Close to the HeartMath Institute claims, in the Hindu philosophical tradition, the anahata chakra is deemed to be the seat of unconditional love and compassion and would be located in the bodily heart and the thymus. In practice, however, the chakra would be located not in a specific part of the body but would work as a layer within the human being, from either 
inside out our outside in. The association of the heart with love as connection from the Hindu tradition finds support also in the Mandarin language, as the character of heart (心), pronounced “Xin”, is a central element of love (愛), pronounced “Ai”, which originally means a form of profound appreciation for others.

David Odorisio, from the California Institute of Integral Studies, notes that the heart is not only a historically rich symbol in Eastern cultures, but also in Western ones. In the Christian tradition of hesychasm, "the heart operates as a locus of integrative functioning or unitive knowing" (Odorisio: 2014, p. 33). In this regard, Odorisio offers a deeper look into the heart as the gate for one's relations to the whole, considering that the anahata chakra is the central point for the process of individuation, the realization of one's own purpose in connection with the universe. Any process of individuation of a human being must require one's capability of having clarity and understanding of what happens, and knowing how one is to act. This form of understanding from anahata, however, does not entail only one's mind, as the capacity of critical reasoning. This understanding also entails attributes such as compassion and equanimity - close to empathy. This interpretation of anahata combining one's critical mind and compassive attitude curiously finds parallel in the Korean language, as it uses the word 마음 (maum) to express both mind and heart and also carry the meaning of intentionality. It is with this figurative, metaphorical understanding of a mind-heart or a heart-mind as a form of connecting with and understanding that I work with in this thesis. Having said this, a more detailed reflection onto the archaeology and definition of love, beyond merely understanding it as connection and appreciation, is of essence, to continue with this research. 


\section{3- Love in Western Culture:}

\section{1- Greek Love:}

If I am to consider Greece to be the cradle of Western thought, the culture I reckon to be a part of as a Brazilian, then an exploration of the concept of love in Greece are of natural order. In ancient Greece, love as we know it was broken into three different names: Eros, Agape and Philia. Roughly speaking, Eros stood for merging and unionship - usually through sex, whilst Agape stood for compassion or fraternal ove. Philia was regarded as friendly affection, and it was differentiated from Eros only when it came to sexual rapprochement, a distinction that has merged in contemporary understandings of love (Bennett: 2013). The differentiation between Eros and Agape, however, instead of merging together, started giving place to more elaborate interpretations and sharp differentiation. Swedish theologian Anders Nygren represents a theological hallmark in the differentiation between Eros and Agape.

In his book Agape and Eros: a study of the Christian idea of love. (1937), Nygren states that the translation of both Greek words Eros and Agape into love as one single noun is an inconvenience, because it leads to the assumption that they go together and mean the same thing. Contrary to such an assumption, Nygren points out that "both represent independently developed historical conceptions (...) two different general attitudes of mind (...) two distinct (...) ethical motifs" (1937: p. 32-33). He posits that the Hellenist love, or Eros, stood for love as desire to reach God, to reach perfection. Eros is the kind of love that has an upward direction and aims at achieving a divine state from man's mundane condition, a "flight from this world" (p. 181). It is also a desire, a longing to become God that is egocentric (p. 175). 
For Nygren, the understanding of love as Eros is manifested in Plato's rendition of the sharp dualism between the world of senses and the world of idea(l)s (p. 169) out of cognition. Eros is salvation from the dark cave in Plato's seventh book of the Republic. And, according to Nygren, Aristotle would inherit the platonic reinterpretation of Eros, extending this human upward force from potentiality to perfection of form to all nature, from lower to higher forms of being (p. 184).

Reacting to the prevailing understanding of Christian love after Plato, Nygren aims to reframe the Christian concept of love and its historical foundation as Agape and no longer as Eros. Agape, in sharp contrast to Eros, would stand for the love and grace of God to his creation; it would be compassion from above into a downwards direction. Agape is Jesus's act of salvation and pity for mankind and the commandment of "thou shalt love thy neighbor". Still, Nygren underscores that neighbor might imply a relation of vicinity, of belonging to a certain context; he highlights that Agape has no limits and extends to all forms of life (p. 63), it is "spontaneous and unmotivated" (p. 75), it is "indifferent to value" (p. 77) and "the initiator of fellowship with God" (p.80).

Yet in my perspective it is hard to limit love to either one or the other as it would lead precisely to a poorer experience of love. In this regard, Dutchwoman Cornelia J. de Vogel contests Nygren's sharp opposition between Eros and Agape. De Vogel was a passionate philosophy historian and had a big interest in Platonism and Neo-Platonism. She was raised in a non-religious family and developed a preoccupation in understanding the place of God in life (Sinnige, 1995). In an article published in 1981, de Vogel shows how Nygren failed to see that Eros, the Hellenistic love, "also cared for the other's soul" and that it also manifested in the form of generosity (p. 62). Meanwhile, she also perceives NeoPlatonist Plotinus' understanding of love as a rather energetic ${ }^{4}$ understanding of oneness.

${ }^{4}$ For a detailed explanation on energetic, see Wolfgang Dietrich and his energetic 
Such understanding of oneness, originally proposed by Ken Wilber (1995) and followed by Wolfgang Dietrich (2012), imply that Eros and Agape are inseparable and complementary to each other. Upward love is love for God, whilst downward love is compassion for God's manifestation in his creation (but not Himself). One interesting element to take into consideration is that, according to Wilber, whenever Eros is unaccompanied by Agape, it becomes Phobos and whenever Agape is without Eros it turns into Thanatos. Phobos represents rejection, fear and phobia, while Thanatos stands for death and disillusionment with the holiness of worldly life.

\section{2- Love in Christianity:}

De Vogel and Dietrich both assert that, in the Christian understanding of God, God is detached from his creation and they are not the same. Such a condition is fundamental to understanding love within Christianity. Nygren attempted to reframe Christian love as neighborly love, as the manifestation of God in the other; however, it is hard to challenge centuries of the imposition of the Catholic Church's interpretation of love as Eros via the influence of Plato, even if it seemed more like Phobos than Eros itself.

Saint Augustine is perhaps the most iconic embodiment of the Christian interpretation of love and its distance from the Hellenistic understanding of love. In his early life, Augustine led a life close to the Greek ideal (pre merging of Philia and Eros and the differentiation between Eros and Agape), and experienced love in an erotic and embodied (from Eros) fashion:

I will now call to mind my past foulness, and the carnal corruptions of my soul; (...)And what was it that I delighted in, but to love, and be loved? but I kept not the measure of love, of mind to mind, friendship's bright boundary: but out of the muddy concupiscence of the

interpretations of peaces in chapter 2 . 
flesh, and the bubblings of youth, mists fumed up which beclouded and overcast my heart, that I could not discern the clear brightness of love from the fog of lustfulness. Both did confusedly boil in me, and hurried my unstayed youth over the precipice of unholy desires (Confessions, book II).

At the same time, however, Augustine's initial approach to love also had a Agapean nature (of compassion and empathy) as the excerpt below talking about theater exemplifies:

Why is it, that man desires to be made sad, beholding doleful and tragical things, which yet himself would no means suffer? yet he desires as a spectator to feel sorrow at them, and this very sorrow is his pleasure. What is this but a miserable madness? for a man is the more affected with these actions, the less free he is from such affections. Howsoever, when he suffers in his own person, it uses to be styled misery: when he compassionates others, then it is mercy. But what sort of compassion is this for feigned and scenical passions? for the auditor is not called on to relieve, but only to grieve: and he applauds the actor of these fictions the more, the more he grieves. And if the calamities of those persons (whether of old times, or mere fiction) be so acted, that the spectator is not moved to tears, he goes away disgusted and criticising; but if he be moved to passion, he stays intent, and weeps for joy (Confessions, Book III).

This excerpt already gives the impression of Augustine's progressive distancing of the Greek ideal. In his Confessions, he looks back to his personal life as form of prayer asking for forgiveness from God for his mundane-ness. In the Book III, Augustine comes to point out that loving God and at the same time loving one's neighbor does not exempt one from being punished, as lust pollutes God's creation. Progressively, the love of Eros turns into Phobos or the obsession with God, into a flight for salvation. This God, whose men are but particles of Him stands as an ultimate goal of life, manifested in the form of ascetism.

On the other hand, and with much less influence on mainstream Christian theology if compared to Saint Augustine's, Saint Francis of Assissi conveys an understanding of love much more balanced in terms of Eros and Agape. Francis of Assissi lived in the turn 
of the XII to the XIII century, some eight centuries later than Augustine (who lived between centuries III and IX), and renounced the wealth of his family of merchant and traders to lead a life closer to nature. Having lived during the Middle Ages, Saint Francis interpreted the world through the lenses of the Bible, and he took to heart Genesis 1, verse 31 saying that all god's creations are beautiful and perfect (Moloney: 2013 p. 2), and belonged only to God indeed, which led him to renounce all material possessions in order to celebrate and honor god's creation, which he considered sacred.

Indeed Assissi's most famous oeuvre, Il Cantigo di Frate Sole (Canticle of Brother Sun) is an ode to "the goodness and beauty of creation (...) an expression of the goodness and beauty of the creator" (Moloney: 2013 p. 2) and, as Moloney puts, "[t]he Canticle is an enraptured song of praise and a fervent prayer; it most certainly is not a theological statement. But underlying the enraptured song is a theology of praise" (Moloney: $2013 \mathrm{p}$. 4). Assissi's canticle and lifestyle are a fundamental interpretation of love and a theology that praises both Eros and Agape for the very attitude of celebration, honoring and respecting all things for their godly nature, which is further supported by Francis' attitude of doing no harm and respecting even those who would question his beliefs and the very sacredness of wordly life. This would refer particularly to the Cathars (Moloney: $2013 \mathrm{p}$. 109), whose religious beliefs furthered Augustine of Hippo's polarization of Godly perfection and the mundanness of materiality and saw the latter as the manifestation of Satan, the opposing, evil God to the good one. The name Cathar in itself derives from purity in greek (Moloney: 2013 p. 105).

\section{3- The Troubadours, Courtly Love and Romanticism:}

Coinciding in time with Assissi and the Cathars, the Troubadours, a group of poets and song composers writing on courtly love, emerged in the 12th century in the 
Mediterranean arch that included Catalonia, the South of France, and North-West Italy, concentrating mostly on the Languedoc (Grant \& Kay: 1999). The troubadours came to have an important - and lasting - impact on the notions of love bred in Europe. Their origins have been object of much debate, not only because nothing emerges on its own and without a context, but because there hasn't been a general agreement to the etymology of the Provençal term Troubadour within Romance languages.

Turns out that the most compelling evidence for the origins of the Troubadours, in meaning and phonetics, came not from the European Romance languages but rather from Arabic. With regards to Arab influence on the Iberian Peninsula, Julián Ribera argues that the Arabic word taraba meant, among others "to sing" and to "entertain by singing" (Rosa Menocal: 1985 p.65). In fact, what at first seems like a local innovation and rupture with traditional poetry composition norms, the use of Provençal - a language with no previous literary status, and the discussion of un-Christian topics as courtly love, find strong resemblance to the kharjas, short lyric pieces in the Mozarabic language (Rosa Menocal: 1985 p.63), the language spoken in the Iberian Peninsula during the Al-Andalus, where and when "the performance of rhymed courtly-love poetry was an integral part of the life of the elite" (Rosa Menocal: 1985 p.67).

The troubadours' courtly love manifested in the songs for and appraisals of his desired lady, the object of his love. In a period in which marriage had nothing to do with affection but with family business, the troubadours sang their infatuation and cathexis for ladies "most of the time absent and unattainable, (...) already married or above the lover's status, which makes it impossible for the love to be consummated" (Mohamad Ali: 2018 p.11) and thus lead to melancholy and suffering. The fact that the lady neither reciprocated nor participated in the troubadours' love exposes how the troubadours' love is but a projection of an ideal life never manifested, far from real engagement with the object of 
their love, amounting almost to some form of martyrdom. Thus, in the troubadours we find echoes of Augustine and the Cathars.

The troubadours themselves became an echo of the past into eighteenth and nineteenth centuries's Romanticism, surprisingly amid or unsurprisingly reacting to, Modernity. As proposed by Michael Ferber, Romanticism was

a European cultural movement, or set of kindred movements, which found in a symbolic and internalized romance plot a vehicle for exploring one's self and its relationship to others and to nature, which privileged the imagination as a faculty higher and more inclusive than reason, which sought solace in or reconciliation with the natural world, which 'detranscendentalized' religion by taking God or the divine as inherent in nature or in the soul and replaced theological doctrine with metaphor and feeling, which honored poetry and all the arts as the highest human creations, and which rebelled against the established canons of neoclassical aesthetics and against both aristocratic and bourgeois social and political norms in favor of values more individual, inward, and emotional" (Ferber: 2010 p.66).

Despite the disapperance of the Troubadours, the core of their concerns, merging art and subjectivity in their relation to the world and objects of their affection and their relation to the divine all transpose into Romanticism.

\section{4- Love in Modernity, Romanticism and Capitalism:}

"We were shown that all that which can be known of God may be made manifest by means which are not derived from anywhere but from ourselves, and from the simple consideration of the nature of our minds" says René Descartes in the beginning of his Meditations on First Philosophy (1934). He continues saying, "whatever force there may be in my reasonings, seeing they belong to philosophy, I cannot hope that they will have much effect on the minds of men, unless you extend to them your protection" (p. 1-3). Through these lines, Descartes invites his fellows to enshrine his brain/mind and thought process, trusting his cognition as his highest faculty as "it is not possible to discover 
elsewhere more perspicacity and solidity, or more integrity and wisdom in pronouncing judgment" (Descartes: 1934: p. 1-3). Reason, which for Descartes stands for knowing through cognition - knowledge - trumps all other human experience, and thus love as a form of knowing then becomes subdued, as it is not considered a means of wisdom.

Descartes is considered one of the founders of modernity because, although modernity is a much-contested term, it has been partially described as "a particular mental attitude that seeks rationally to understand the world we live in", which led to a concern over order, control and planning of life and the world via science, in the wake of European enlightenment (Gregory et al: 2009 p.471). Knowing is understood as providing order, control, and planning of life explain many of historical fact associated with modernity, and critiques of it will highlight specially the placing of European history as world history, colonialism, slavery, capitalism, war, the creation of nation-states, but also secularism, human rights and globalization as constitutive elements of modernity. Of these, I highlight below the association of modernity with rationality, order, and capitalism and its impact on an understanding of love, focusing on developments within nineteenth century Europe.

Following Descartes, the gradual distancing from the authority of the Church in the interpretation of the world and of what to love, towards Modernity's freedom to exercise reason, one could assume that trust in our own cognition would allow people to reclaim their full selves and explore all of their faculties - loving as source of knowing included. However, the prominence of reason also meant that any other faculties were considered inferior to it, thus regarding love as a lesser human faculty, as a mere form of feelings and or emotions. Despite the modernist effort of repressing all subjective matters such as feelings, emotions such as love (in their temporal understanding), the ghost of the troubadours insisted on sneaking back, tinting the apparently objective approach towards an ordered world with their own kind of subjectivity, with two noticeable dimensions when 
it came to love: love for the nation-state, love, capitalism and socioeconomic conditions within romanticism.

Within Euro-modernity, the suffering of the poetic troubadour in conquering his idealized maiden, transformed into the suffering of the lover portraying and pursuing an ideal society, his own land, singing in the local "national" languages with folkloric backdrops, coincided with the French Revolution against the Napoleonic Empire and in favor of the people, their folks. Unsurprisingly, "liberty, equality and fraternity" was the motto of the French patriotic revolutionaries. In this manner, love in Euro-modernity heightened the sacrifices a patriot was expected to make to the grand object of their love the people who conformed to their nation - who fought to create an ideal country. The patriotic identification of a shared history and language gave rise to identity markers that, within the social and political context of Europe, easily converted into nationalism, a necessarily narrow and exclusivist view of love that ends whenever identities differ, and which had significant consequences for warfare and eventually, International Studies.

At the same time, the ordering attitude that could conform to a nation-state was also present in the domestic realms. Accompanying the rapid industrialization and urbanization of XIX century Europe, there was a significant spike in birth rates and populational growth, associated with the rise in marriages (Haines: 2019). Depending on a family's socioeconomic conditions, children either served as labor and, consequently, higher income for the family, or heirs, guaranteeing the continuation of bourgeois wealth within a family. The concern over labor and wealth give evidence to the rise of capitalism. Amid the industrialization and poor conditions of living in the cities or the harsh conditions of living in the countryside, Romanticism, as escapism, sensibility, and emotional attention to the feelings bred from dealing with harsh reality, served as response to the changes taking place in Europe, feeding off the beauty of life in nature (to which Rousseau was a precursor), 
chivalry and romance. The heightened emotive subjectivity at least allowed people to project some drama within the social conventions of marriage (and reproduction), present particularly in the literature of Austen or Balzac.

Within Euro-modernity (and capitalism) and its romantic reaction, the response to one's conditions and reality was either rationally or emotionally based, neither accounting for a critical assessment of the limitations or possibilities of integration - amounting to either the inexistence, irrelevance of love, or a rather limited understanding of it - the one that plagues popular culture nowadays, of having a romantic partner.

Contrary to this prevailing understanding, George Nakhnikian argues that my principal thesis is that love is an essential component of human reason. Reason is the synergetic union of the power to know and the power to love. Reason in man [sic] is practical only because it is more than a faculty of cognition. Human beings can conceive of what it is to live well, and they have at the same time a passional, an emotionally charged concern, for securing their own well-being. The concept of well-being and the conation for well-being both belong to reason. The fashionable apartheid between reason and passion, between thinking and feeling, is false and harmful. Cold "rationality," passionless "objectivity," far from being marks of human excellence, are forms of irrationality. Reason as passion is reason as love. (Nakhnikian: 1978 p.287)

Despite Nakhnikian's hind(in)sight, in the twentieth century, Western individualism and Capitalism will lead to a significant commodification of love. The standing effects of individualism in the West - another aspect of Euro-modernity' atomism and substantive ontology - has generated an existential loneliness for which the solution is found in romantic notion of finding a partner, and thus conquering love. This is taken further under capitalism's commodification of love upon making it available for a certain price: from marriages of convenience that takes one partner from financial precarity and a diligent partner willing to serve once one goes home, to easy sex and prostitution, and pornography consumption in lieu of the difficult art of relating to and living with others. 


\section{5- Love as Intimacy and Sexuality, and Queer Love:}

From the above considerations, the following contentions about intimacy, and proximity and thus of knowing and finally relating, might be highlighted:

- in the Greek tradition, the notions of Erotic (form Eros), Agapean, and Philian love all presupposed a certain degree of proximity and intimacy with others in order to know know fellow human beings, though in the erotic version it also included a dimension of intimacy and proximity via sex.

- In the Christian tradition, the aspects of proximity and intimacy were not any different, except for that fact that intimacy and proximity were geared towards knowing, realizing and relating to god, and fellow human beings were only a medium towards that - the Augustinian and Assissian traditions only differed in god's location - either in heaven or within earthly beings, respectively.

- In the troubadours' and romanticist notions of love, the unfulfilled quest towards proximity and intimacy with the lover prevented actually knowing of others.

- Meanwhile, within Euro-modernity and capitalism, proximity and intimacy served to establish machinations for a perfect society, in the continuous reproduction and improvement of itself - thus also of idealizations.

It is therefore reasonable to assume that the conflation of troubadourian/romanticist and modern and capitalistic notions of love, in which knowing of others is never fulfilled and proximity and intimacy only serve social reproduction, would als be found in heternormativity, the heterosexual marriage and "straight" sex as ideal types representative of the norm or "normal."

Yet, it is fair to question if a non-reproductive and yet fulfilled/fulfilling subversiveness of proximity and intimacy might as well lead to a deeper form of knowing, 
of relating and, therefore, of loving. Going against the Euro-modern and romantic grain, this is the plight posed by queer perspectives, as a "resistance to standardization of emotional life" (Halperin: 2019 p.398), as responses to the enforcement of a heterosexual and reproductive norms of intimacy, towards alternative and more meaningful ways of loving and of relating, that remain true to human diversity.

Although in contemporary Western society we find big portions of LGBTQ+ people advocating their right to marriage and thus befitting from the modern-capitalistic and romantic canons, queer love stands as a radical search for different forms of loving and relating - a counter-culture in the words of Foucault. In the words of David Halperin: "as an inchoate ethical or political impulse, (...) [asking] how well love and society actually go together" (Halperin: 2019 p.398).

Mimi Marinucci argues that positivism, Western or Euro-modern philosophy and scientific objectivity all contest and reject what I argue above - that intimacy may provide particular (and unique) forms of knowing (and of relating) - as they assume that the resulting pluralism amounts to a problematic "anything goes". In consequence, she argues: those of us who are prepared to abandon the ideal of objectivity but unprepared to abandon normative epistemology now bear the burden of integrating the diverse range of subjective human experiences into our conception of knowledge without thereby submitting to a hopeless skepticism or a wholesale relativism. (Marinucci: 2010 p.302)

In order to address the tradeoff derived from hopeless skepticism or wholesale relativism, Marinucci discusses how we come to know, through a differentiation between the German verbs wissen and können:

While wissen conveys knowledge of facts, können conveys knowledge of how to do something. The verb kennen refers to knowing in the sense of being familiar with someone or something, and the verb kennenlernen refers to the process of becoming familiar with someone or something. Ordinary epistemic contexts and specialized scientific contexts both involve people attempting to become familiar with things, yet Wissenschaft, the German term for science, refers primarily to propositional knowledge. This is a reminder of the 
priority that has been granted to propositional knowledge throughout history $(\ldots)$ however, [familiarity] strikes me as the more fundamental form of knowing from which propositional knowledge derives (Marinucci: 2010 p.304).

Against assumptions of objectivity and propositional knowledge, and equally discarding sheer relativism, Marinucci then argues that, in the act of learning, the quality of the relationship between knower and known not only matter but also "invite collaboration" and interaction - reinforcing many feminist perspectives. After all, we are human beings relating to each other, and it is important to understand how do so - and feedback and exchange form a vital part. Only in this way may we provide contingent answers to the challenges of relating. In my eyes, Marinucci unfolds a possible epistemology of love, through continuous engagement, familiarity, and participation.

\section{4- Erich Fromm: What is Love? What Love is not?}

Erich Fromm's The Art of Loving was first published in English in 1957 (the original was published in German the year before). The Art of Loving (1995) has become an international bestseller for providing an encompassing discussion of every aspect of love and for providing a compelling critique of Western society's disintegration of this love. Half a century since its first publication, the book remains oddly contemporary in my opinion.

Fromm was a psychoanalyst and sociologist born in Frankfurt in 1900. Being a Jew in Germany during the beginning of the twentieth century and having professional relations with the Frankfurt School stimulated Fromm to reflect on society, on human relations, on what it means to live and how to do so as to be a free individual. The titles of his most famous books provide a clear image of Fromm's main concerns as a scholar, therapist and human being: The Heart of Man - Its Genius for Good and Evil; On Being Human; The Art 
of Loving; The Art of Being; To Have and to Be; Man for Himself - An Inquiry into the Psychology of Ethics; The Sane Society.

In The Art of Loving, Fromm presents love as an art that requires knowledge, effort and commitment. He contrasts it to the peculiar (and prevalent) idea that love concerns being loved rather than loving, or being the object of love rather than nurturing the capacity to love. Fromm notes that the capacity to love is something present in all human beings. When one's concerns reside on being loved, much like the universalized concept of romantic love, the focus seems to reside mostly in becoming an object that is lovable, desired. This attitude implies an easiness of loving or, better said, the simplistic happening of "falling in love". Contrary to that, Fromm argues that love, as an art, requires one to master its theory, its practice and seeing it as the ultimate goal one has in life. He goes further into this by explaining how contemporary society puts so much ahead of love, like career, success, money and power.

Fromm considers that any approach towards love has to start with a consideration of men, though what he means is a consideration of human beings and not men in particular. He considers that human nature is to find harmony (p. 6) and that humans are a life being aware of itself in relation to others. It is because of this awareness of oneself as an apparently separate being from others, and its consequently perceived fragility, that humans seek to reach out from their prison as individuals into the communion with other beings or the world. Fromm considers this search the deepest need of humans. The question that arises from such a condition is then "how to transcend one's own individual life and find at-onement" (1995: p.8). Fromm remarks that over history such onement was once found in orgiastic states promoted by "primitive society's rituals", but that it can also be found in contemporary societies in the guise of, for instance, citizenship, and how this belonging can either be promoted by fear or by will. In any event, he considers that such 
experiences remain simplistic experiences of unity that barely resemble what the full achievement of interpersonal union or fusion with another person might represent through love (1995: p.14).

Even so, Fromm notes that not all interpersonal unions could be called love. For instance, Fromm considers symbiotic unions as an immature form of union because of its very essence of mutual dependence. On another hand, mature unions represent a manifestation of the power of love because it preserves one's integrity, despite the search for union. "[L]ove makes [humans] overcome the sense of isolation and separateness, yet it permits [them] to be [themselves], to retain [their] integrity. In love the paradox occurs that two beings become one yet remain two" (1995: p.16).

In this sense, I can understand love, as overcoming separateness, as an activity. Yet, such activity should not be understood as a means to achieve an outside goal, for instance to get someone to love me back. If love is an activity, it is a continuous state of giving for the sake of giving. Fromm considers that "giving is the highest expression of potency. In the very act of giving I experience my strength, my wealth, my power" (1995: p.18). But Fromm cautions that giving should not be confused with giving up, becoming deprived of something or sacrificing: only " $[\mathrm{t}]$ he person whose character has not developed beyond the stage of the receptive, exploitative (...) experiences the act of giving in this way." (1995: p.18). Some go as far as making their own sacrifice a virtue, when, in reality, the manifestation of love as giving cannot help but reflect back to the giver. This giving does not impoverish or sacrifice one but enriches him/her/them by multiplying and spreading itself. The active nature of loving through giving oneself multiplies love instead of simply transferring it, and that such an awareness prevents one from giving love with the expectation/demand of receiving it back; love reflects back anyway. Fromm also states that "the ability of giving depends on the character development of [a] person" (1995: p.20). I 
shall agree with such statement as long as it does not imply that people are determined to reach such a developed and final stage, even if I claim that in love relies one answer to the problems I perceive in contemporary society.

In any event, I do agree with Fromm when he states that in order for someone to actively give love (or simply love) in this fulfilling manner, certain mutually interdependent elements have to be cultivated in one: "care, responsibility, respect and knowledge" (1995: p.21). By care, Fromm means the "active concern for the life and growth of that which we love" (1995: p.21) and that from it responsibility inevitably arises, since because of caring one becomes responsible, able and prone to respond to the needs of another human being. At the same time, in order for this responsibility not to become control, respect becomes another element for raising the awareness of one's uniqueness and particular process of unfolding for one's own sake. Finally, one cannot respect someone if she does not get to know the person - not necessarily in person, but if this is the case, it presupposes the act of reaching out and learning about as much as possible. It is about that sort of knowing that allows one to intuit deeply another one's state, be sensitive to that and be able to accept it. Of course, this knowledge is not of an invasive quality that peers in on one's insides, but the knowing derived from the encounter, union as if both were one, a radical intimacy. Only this knowledge that lies in the act of love can be considered a full one.

\section{1: Different expressions of loving:}

In The Art of Loving, Fromm explores many different manifestations of love and how they contribute to one's potential of loving. Each of them brings about an opportunity of learning different ways of expressing love, but there are two fundamental kinds of love: motherly and fatherly love. In a healthy mother-child relation, the relation teaches the growing child that she is loved for who she is, for her fragility, for her need and dependence 
of others, since mother love is unconditional. This in turn teaches the child to love back and appreciate, be grateful to the love received. This teaches the child how loving produces love back. Moreover, it teaches the child to love and appreciate this life.

Meanwhile, in a healthy father-child relation, the fatherly figure stands for unfolding, before the child's eyes, the ways of the world, the discipline necessary to it, and his love derives from the child's fitting to the challenge of living. While motherly love is loving human's essence, fatherly love is loving humans potential. Of course, both motherly and fatherly love correspond to ideal types ${ }^{5}$ and in no way they have to stand to a biologically and gendered mother or father, or that they cannot be paradoxically found in one figure. It is about the sort of love and not the sort of persona that portrays it. In this sense, the "balanced" individual is one who has built within himself both a motherly and a fatherly conscience (1995: p.30-36). This sort of love is of a formative nature, it helps shape how I perceive my place in the world in which I find myself.

Fromm stresses, however, that there are other forms of love, and of relevance for this work I shall mention his understanding of "brotherly love", "self-love" and "love of God". Brotherly love stands for the sort of love that represents "the union with all [humans], of human solidarity, of human at-onement. Brotherly love is based on the experience that we are all one" (1995: p.37) and that I actualize myself when I actualize you. It is about going beyond differences and recognizing the uniqueness of the other and also the sameness between you and I.

According to Fromm, another important type of love is self-love. Yet, self-love, in many contexts, particularly the Christian context, is condemned for being associated with selfishness and egotism. But if love is the expression of at-onement, there is no expression

\footnotetext{
${ }^{5}$ Of course both motherly and fatherly love also have negative sides, and the lack of balance in the relation between those figures and the growing child can generate issues for the child, such as a dependency in motherly love and rebelliousness in fatherly love.
} 
of love that can exclude the person who loves. "Love of others and love of ourselves are not alternatives", Fromm States (1995: p.46). Because selfishness is the constant demand for oneself, it denounces the insatiableness of one's emptiness and, in this sense, represents the lack of love because love fulfills one, to the extent that we can only give it away. Brotherly and self-love are kinds of love of an autonomous nature, in the sense that the individual "negotiates" on their own relations to himself and others.

Finally, for Fromm, there is the love of God. It is not an easy task to discuss the love of God considering the infinite number of religious and spiritual practices in the world and their views of God. From being the fertile earth, to a Female principle, to a commanding father figure, to the nothingness, to all these forms of God there is a corresponding relation of love of God. What Fromm highlights is that in none of these can we dissociate the recognition of others as part of this All One or part of its sacred creation. Therefore the love of God cannot only be manifested in an appraisal of above but must also be celebrated in the relationship between all godly or god-created, emanated things. The question that remains is how our own lives condition us to unfold our potential to love the principle of God. With this, the sort of love that love of God represents is a love of purpose, of meaning in a process of formation - from motherly and fatherly love - to how the autonomously decides how to engage with himself and others (in brotherly and self love).

\section{2: Love as Art:}

To have understood love allows me to unfold how my potential to love becomes an art. As any unique work of art, it cannot mechanically be reproduced without being a mere copy, a glimpse of all the energy invested in the original. Having said that, Fromm argues that there are techniques for developing and practicing one's own art that can facilitate and refine the creation of such art (1995: p.84-). The first of which would be discipline. In order 
to excel in something, I have to cultivate the habit of practicing it frequently, and not whenever I "feel like". It is true that, in our Western-modern context where one has to dedicate so much time and energy to work and to make a living, little disposition comes for practicing an art with discipline.

Discipline, on its hand, cannot be separated from concentration. Concentration, in this sense, is the willingness to remain focused on the work of art. In a world in which we are drowned into a myriad of information, it becomes very easy for someone to become distracted by trying to absorb everything around us. And, because most works of art are not only products of genius, but also a commitment to the highest form, patience becomes a necessary virtue in the art of loving. Then again, the practice of patience is highly disregarded in a society that requires everything to be immediate. Lastly, no mastery of a work of art can be achieved without a supreme concern for this art that becomes present in every moment of one's life. The mastery of a unique work of art, by its very definition, requires the skill of putting together the elements that allow the work of art to be created. Therefore, no mastery can be achieved without the practice of such art.

On top of the required skills for developing any sort of art, different kinds of art have different and specific needs. In the art of loving, Fromm mentions that the first step is to overcome narcissism, as a way to see the world only from the perspective of oneself. It does not allow for a practice of love because it does not manage to integrate the other's perspective by putting one "in the shoes of another". Narcissism is seeing the world only through one's own lenses, and in this sense means losing objectivity of what goes on outside of my own bellybutton. I cannot try to understand the other if I do not try to see things from his perspective. And the realization that there are multiple, infinite perspectives produces a twofold phenomena: on an emotional level, it brings about humility to accept our 
limitedness; on a cognitive level it facilitates the unfolding of capability, reasoning out the most appropriate perspective in each context.

Along with overcoming narcissism, according to Fromm, another fundamental aspect of the art of loving is faith. Here, a fundamental differentiation must be made to the current understanding of faith. In the art of loving, faith does not stand for the blind or irrational belief in a superior authority, but rather trust in one's own capabilities. It can be best expressed in the phrase "he who did not know it was impossible, did it". Faith then is the product of both cognitive and emotional activity. This means that I cannot manage to practice the art of love unless I have the intention and the trust that I can do it within me. This cognitive act of planning, of reasoning, is an important element of faith in the art of loving, but this reasoning is not achieved by thought and judgment only. Faith is also relational. It can be expressed in faith in others, but in order to have faith in others I must have developed faith in myself as a human. I must see that the other bears just as many potentialities as I do. Ultimately, this translates in the belief in the potentiality of the whole of humankind for developing the art of love, which in turn inevitably leads to the productivity of love.

Fromm poses that another element of the art of loving is courage. I have to be bold and trust that I can go beyond my currently given capabilities. This could not have been better expressed than with Paulo Freire's realization of the impossibility of perceiving the untested feasibility that lies beyond the limits of one's own experience. The leap beyond the limits of one's own experience is a daring move and implies risk. It simply cannot take place if I remain in a secure position. The artistic activity of love requires diligence, readiness and a constant exercising of it; it cannot simply cease beyond the easy and immediate surroundings of the family, of the social context. It has to be present also in those aspects that one finds most difficult to embrace and have compassion for, which 
manifests in terms of an ethics. This poses a drastic change in the relation I establish with society, with the other. According to Fromm, this compassion does not consubstantiate in fairness, as in giving others what is rightfully theirs, but instead it manifests in an inherent capacity of loving beyond measure, which I understand as being of service for the collective wellness.

\section{5- Thich Nhat Hanh's True Love:}

Thich Nhat Hanh, a Vietnamese monk formed in the Tu Hieu Temple from Hue (Central Vietnam), has been engaged with the renewal of Vietnamese Buddhism (and spread in the West) since the early 1950s. With the outbreak of the Vietnam war, Nhat Hanh and other Buddhist monks and nuns were confronted with the issue of continuing with their contemplative life of meditation in the monasteries or helping those affected by the violence of war and bombings. Nhat Hanh decided to do both things and, in the process, he coined the term Engaged Buddhism, ${ }^{6}$ which aims to bridge a Buddhist perspective with everyday life issues on the realms of politics, economics, social affairs, justice and the environment (Plum Village: n.d.). Ever since, Nhat Hanh has been a peace and meditation activist who has written extensively on those matters, also covering the topic of love.

In his book, True Love: A practice for Awakening the Heart (2004), Nhat Hanh mentions that Love has four aspects according to Buddhism, also known as the four incommensurables: the first one, known as maitri, could be translated into loving-kindness.

\footnotetext{
${ }^{6}$ Engaged Buddhism and Nhat Hanh's initiative are connected to the mahayana tradition in Buddhism. Mahayana's core tenet is that one's own process of illumination should have as its purpose not reaching this state of illumination for oneself, but for the altruistic service of dimishing the suffering of fellow living beings (bodhicitta). Mahayana, also known as 'great vehicle', has been a response to the Theravada, the oldest bhuddhist tradition which focuses more on personal liberation of suffering - following bodhisattva or the path of illumination. There is yet, a third tradition known as vajrayana, which renounces to nothing, and embraces and adresses all suffering and difficulties with determination, as means to go through illumination.
} 
This loving-kindness represents the capability of bringing joy and happiness to others, but such a capability cannot manifest if one does not make an effort to deeply try to understand the other, look deeply and be attentive to him, to be understanding of their state or condition and have a serene gentleness and acceptance of his being. The following element in love is the compassion that derives from this understanding, known as karuna. Such a compassion unfolds into the ability to ease one's suffering, responding to it. Therefore, it requires knowledge. The third element of true love according to Buddhism is mudita, or joy. In the act of love one has to feel a fulfilling joy that makes such an action so rewarding and sought after, it nourishes one's soul. If through my own suffering I cannot still experience the joy that derives from contemplating life in all its aspects, even the darkest ones, then I can not love either myself or others. Once these three elements are present, then the fourth element of love can manifest. Upkesha says that when I love, I can bring freedom to the ones I love. Upkesha is the liberation that the heart provides for life to follow its own course (Nhat Hanh: 2004, chapter 1). ${ }^{7}$

For Nhat Hanh, love comprises the ability of being present for the present, being entirely aware (with mind and body) of where one finds oneself, and responding accordingly to every moment in the here and now. The capability of being present also unfolds into the capability of recognizing the presence of the other. Love, as an undeniable union between all beings, requires the mindful acknowledgement of the other. In certain circumstances of suffering, loving requests that I become present for and make myself available for the other. But if I am the one suffering, I should also develop the humbleness of communicating and being earnest on my issues, shattering pride that reinforces individualism (Nhat Hanh: 2004, chapters 2-5).

\footnotetext{
${ }^{7}$ In some ebooks, due to the different modes of visualization, the page numberings vary. In order to be as precise as possible, I identify, in those cases, the chapter where the information is available.
} 
In Nhat Hanh's perspective on love, it is possible to see the parallels with Fromm's perspective of love as ultimate union, how karuna manifests into motherly love, how upkesha represents the fatherly love committed to one's unfolding process, and how mudita both represents brotherly love and love of God for the realization of the bliss of life in union. It is worthy mentioning that all of these elements can also to be found in Fromm's love for oneself as a discovery of joy through maitri. Moreover, Fromm's subtle art of loving, with its required discipline, courage and openness are the same as what Nhat Hanh considers the abilities of being present, recognition and overcoming pride.

\section{6- Abraham Maslow: Exploring Human Potential for love:}

Fromm's The Art of Loving offers an elaborate meaning of love as art in the psyche of humans. It attends to a socio-politically inclined audience, while detailing how love can be manifested and the specific skills necessary for someone to practice such an art. Nhat Hanh, on the one hand, has encapsulated all of Fromm's main tenets on love focusing on one's own life and personal actions. In this vein, love is an art that every human being has and is capable of developing. Love, in this sense, is unconditional. It can be explored and experienced no matter the life conditions one has faced. Yet, attending basic needs and creating nurturing space in which people are motivated for self-actualization makes the mastery of love a much more sought-after activity. Also, love manifests as well in the desire of providing an account to historical, cultural, political and economical conditions, of course.

With Abraham Maslow it becomes possible to explore a Weltanschauung in which a self-actualizing person finds stimulus to enter a process of operating her full-humanness and potential of loving. Born in 1908, Maslow was an US American psychologist and one 
of the founders of humanistic psychology. In a reaction to the behaviorist assumptions that the environment conditioned the nature of the individual humanistic psychology, Maslow claimed that creative self-actualization was an inherent trait to human beings.

Among Maslow's main concerns was the psychology of balanced individuals in their own life, as he affirmed that "the end product of growth teaches us much about the processes of growth" (Maslow: 2013, p.64). His research revolved around asking why psychologists focused so much on the illnesses of people and how a more complete account of the human experience could be of relevance especially for the healing process of the ill. Maslow considered that traits of healed individuals give an account of the challenges they have experienced and how they faced it, and thus may indicate paths for those seeking healing.

According to Maslow, this perspective brings about a revolution, a new form of thinking and of perceiving, and renders possible new representations of humankind and society, because they shift from focusing only on the lower experiences of sickly human beings. At the same time, Maslow reaffirms that this growth needs to be understood not as a linear process towards an end stage but as several dynamic processes that clearly relate with "being, rather than becoming" (Maslow: 2013, p.67). It is for the very sake that I can understand love as a trait that can be manifested in human beings who have experienced the most abject life situations, even if this might be a difficult task. It is not about a linear and ascending process. It is about understanding that one's capacity to love might be subdued, hampered when certain elements in one's life are lacking, but that this capacity can never be taken away.

In any event, in order for human beings to reach their full-humanness and the potential of loving through a healthy life, it becomes clear that certain needs must be met as to fully unfold the potential of love. As in a system, every tiny element (or its lack) 
affects and changes the entire system and its dynamics. Once a need is perceived and the conditions to fulfill this need are present, this need does not have to be feared or dreaded but can be welcomed as an experience that is enriching and gratifying, as it brings about dynamism to the system; love is no different (Maslow: 2013). In a nurturing context where I have experienced my need for love and it has been met, I do not only call love forth to myself but also those elements I consider catalysts of my loving potential, and I no longer focus so much on being on the receiving end but rather on the giving side.

This requires understanding the difference between love as a deficiency and love as motivation, which Maslow refers to as Needing Love and Un-needing love, respectively (or yet D-love - as in deficiency and B-love, as in being) (Maslow: 2013 p.103). Love as a motivation is an activity that is sought after and enjoyed, and offer higher experiences between people, who look at it in a serene manner, instead of anxious and desperate, as if their life depended on it. All of a sudden, the drive for love and enjoying giving love in this state of "being love" suddenly turns into becoming, in a rather unanticipated manner.

Only the lover might choose when he is truly ready to venture into love. As a natural process, every individual has his/her own time, depending on how his/her life conditions have affected his/her own potential for love. This makes it all the more important to respect and understand one's unfolding abilities. If I teach people the right way of doing things, I do not allow them to find the trust in themselves to do things, but generate instead a dependency on my own abilities. Moreover, not trusting and respecting one's process of unfolding brings about the impression that this person is not able or capable of blossoming. This might deeply affect the person's belief in him/herself, ultimately hampering his/her entire process. As spectators of people's own unfolding potential, all choices made have their validity, either for momentary self-preservation or daringness, as both bring about a learning outcome. 
Yet, it is hard to talk about trust without also mentioning fear. Maslow masterfully describes how our fears of what makes us shameful, weak or evil lead us to withdraw from certain situations. Maslow also asserts that sometimes those things that bring about growth and that puts oneself in a situation of outdoing previous states of comfort might lead to deflection because they generate changes into something yet unknown and that one might not be ready for (Maslow: 2013, p.143-144). Still, for any latent talent to blossom and any art to be mastered, one has to face this challenge, if they are to self-affirm themselves as one who has experienced this unfolding of talent and mastery.

According to Maslow's research with several individuals who underwent the unfolding of a talent and mastery of art, the practice of opening one's heart makes loving a less difficult task by the mere gathering of experience, and accumulated experience in dealing with other people brings about awareness of processes of relating and their difficulties. This sort of awareness is one that allows oneself to see wholeness and to have an acute attention to and general perception of things. It consciously prevents entering reactive and egoic modes of being and allows oneself to find understading and ways of action in any situation and accept them as such (Maslow: 2013 p.220).

\section{7- Carl Rogers: The shape love takes in practice:}

While with Erich Fromm I explored an abstract idea of loving as a form of social art, with Maslow I have explored certain conditions in order to harness the potential of loving. With Nhat Hanh, I explored one's attitude and intention of loving in his/her life. Now, with Carl Ramson Rogers, I would like to explore how this art takes shape in the relational encounter between human beings. Carol Rogers, born in 1902 in Illinois, was raised in a family that made an effort of raising their children distant from "moral corruption", allowing them to develop their sensitivities (Kirschenbaum: 2004). During his 
adulthood, Rogers became famous for his client-centered or person-centered approach. He is considered one of the founders of humanistic psychology.

As a trained psychotherapist, Rogers started growing suspicious of how effective the traditional approach of experts and trained therapists was to their patients. Their approach emanated from their position of authority and power to give a correct diagnosis for the conditions suffered by those who sought help. Rogers, however, in a move that one might consider related to the sensitivities nurtured by his family, started relying on his patients to uncover their own self-healing powers instead of assessing, diagnosing and prescribing solutions as an expert. This ultimately led him to no longer perceive people who looked for help as patients, but as people with latent potential to self-heal and grow, people who simply sought support, companionship and guidance in their own process. Rogers noted that in a people-centered process, he did not empower people; he simply realized they always had power all along - though they may not have exerted it; he simply rejected assumptions that these people were not good (Rogers: 1977). Rogers searched for the good things in human beings, refusing to see in them sick people, patients, but as fully capable clients, who were looking for novel ways of learning how to deal with the situations in which they found themselves.

Rogers saw that humans are trustworthy beings and that they have the capabilities to understand themselves, to modify the perception of themselves their attitudes and their path. These capabilities might be suppressed or understimulated in one individual, but they cannot ever be taken away (Rogers: 1977, p.4). It is also true that the conditions of life of certain individuals were so unfavorable for their process of self-discovery that their situation might seem bizarre and abnormal. However, Rogers sees in them a desperate effort to become a fully able human, in whichever way possible. 
Rogers notes that there are three basic conditions to generate an attitude and environment that fosters self-growth to be met by the peers of an individual in question: authenticity and transparency, acceptance and cherishing and empathic understanding (Rogers: 1977, p. 5-9). The first condition, authenticity and transparency, tells about not hiding one's own self from people, demonstrating openly one's own feelings - so the other does not assume these in their own head. The more conscious one is of one's own feelings, whether positive or negative, the more one can express them in a way that eases the other person to demonstrate their own. Rogers claims that it is the expression of feelings, and not of judgments and opinions, that support people (Rogers: 1977, 5-6).

Acceptance and cherishing, as the second condition, tell about unconditional compassion for the present state of oneself. It is appreciation for whatever situation in which I find someone and my own self, accepting and working with whatever feelings are present, no matter how negative they are. It is about trying not to control it, but rather observing, understanding and responding to it. Rogers cautions that it is not possible to be accepting all the time, and that this should not be imposed. If this condition can simply be present often in the relationship with my own self and others, the more favorable the process will be. The consequence of this is always leaving the decision over one's own life in one's own hands and likewise, leaving the decision over someone else's life in their own hands. This creates a nurturing environment without pressure to change (Rogers: 1977, p. 6).

The third element for the creation of an environment that stimulates self-growth as an exploration of one's own capabilities is empathic understanding. Empathic understanding is a process of taking a plunge into the world of a person and expressing with precision the feelings and personal meanings experimented by the person and communicating it to him/her. At its best this creates a bridge between two people implicated into a process and one of them to express the conscious and unconscious things the other 
perhaps could not see. Being empathic is about honoring the other and paying attention to his/her world without taking control of it. The example of acceptance and empathy show that everyone can act in such way, no matter the feeling in question. Whenever I see that someone is able of accepting my own self in my negative traits, I gain the possibility of choosing whether I would also like to use those kind eyes onto my own self and others, disempowering my own negative potential.

In a nutshell, Rogers' approach is one that focuses on the inherent human potential for self-growth, for realizing and celebrating embodied lives in relation to one's surroundings and particularly to the people composing that landscape. For Rogers, even in the darkest of situations, personal power arises from the willingness to engage with whatever is at present.

With the reflection made by Rogers in On Personal Power (1977) the tenets of love noted by Fromm in The Art of Loving (1957), that is knowledge, effort and commitment are all present, even though Rogers himself never used the terms "love" or "loving" himself. In Rogers' work, knowledge of loving is an activity that one performs in relationship with others, instead of expecting to be loved. It is an activity that requires the effort to see human beings in their entirety - even their darkest corners, and commitment and persistence to nurture people's innate potential to connect and become their own canvases for continuously practicing the art of loving. At the same time, Rogers' work also contains, in a practical way, Maslow's perspective of the relationship between oneself and the other as the act of "being in love" in opposition of having reached love for someone and moving on. While Maslow only devises this potential into human beings, Rogers exercises it in the rapport between himself and his "clients". 


\section{8-Martin Buber's philosophy of encounter and dialogue:}

If Rogers drew his insights from his practical experience as counselor, in many ways, Martin Mordechai Buber could be considered Roger's philosophical and theological counterpart, dealing with the same topic of human encounter through the perspective of his own form of existencialism and Jewish mysticism. Buber was born in Vienna in 1878 and was raised by his grandparents, who belonged to the Hassidic tradition with Orthodox Judaism, a tradition that sought to organize life in way that honored and celebrated its mystical sacredness, as it understood all life to be the manifestation of an omnipresent God. It is not surprising, thus, that Rogers' practical counselling would converge so much with Buber's thought on human encounter, which inclusively led them to an actual encounter promoted by philosopher Maurice Friedman at the University of Michigan in 1957 which later was published as The Carl Rogers Martin Buber Dialogue (Merrill: 2008).

In I and Thou (Buber: 1996), Buber attributes the idea of human encounter to the constitutive aspect of life, understanding human beings as relational beings, which are always (re-)shaped by the nature of our actions. For Buber, we are conformed by the experiences we make with each other, which are broken down in 3 essential aspects of life: nature, fellow men (sic), and spirituality. However, Buber admonishes that the I-Thou relationship drastically differs from an I-It relation in the sense that I-Thou, as demonstrated with the use of the formal pronoun disused in English, granting respect and reverence to the other, is always an encounter marked by openneness and respect for one's uniqueness, as if Thou always ultimately referred to a godhead. In contrast, I-It would represent those relations in which through my actions I do not regard the other as a subject in itself, ascribing to them the nature of an object. Therefore, even things such as animals and trees can cease to be an "it" and become a "Thou" (Friedman: 2002). 
The challenge of "thou-ing" others lies in the skillful and creative exploration of ways in which encounters can be celebrated, when infinite possibilities are brought to the altar of form, although form, if one is to transform the I-it to an I-Thou relation, is meant not as a pre-defined plan, or purpose, or premeditation, and is always unmediated. That is why encounters demand the unconditional openness and presence devoid of pre-conceived ideas that constitute refuges to life's own vitality in the encounter. This is the context in which Buber's most famous phrase comes up: "all real living is meeting", or in the less poetic translation by Kaufmann edition: “All actual life is encounter” (Buber: 1996).

In this attitude of "thou-ing", which I understand as an attitude of loving, Buber also drives away from the common understanding of love when he considers that feelings accompany the metaphysical and metapsychical fact of loving, but they do not constitute it: "feelings one 'has'. Love occurs (...) as a cosmic force" (Buber: 1996 p.66), in one's own actions of "thou-ing", decentering from one's own experience and interpretation of meeting. To this movement of conceding grace to the encounter and dialogue beyond one's feelings and any possible attachments that come with it (emotions in particular), lies the the fact that I-Thou is always in itself in relation to I-It, as it is the loose relationship I-it that gives meaning to I-thou and its contextual authenticity (Friedman: 2002).

Also, Buber concedes that any form of dialogue, any form of relating requires mutuality, and it happens only if the other is also willing to meet one on the same terms. At this injunction, the exchange of letters between Buber and Gandhi is important because when Buber expressed to Gandhi his concerns about the Nazi politics towards Jews, Gandhi invited him to act with satiagraha (non-violence) towards Nazi Germans (Guilherme \& Morgan: 2011), which was not only impossible in the face of Nazi dehumanizing and antithou-ing of Jews, but also would have led to the suppression of many lives and, consequently, of many real meetings. In this situation, the highest form of thou-ing Nazi 
germans would be to hold them accountable for their actions and condemn them in their dehumanizing politics and policies Since Gandhi's concept of satiagraha did not entail passiveness, it is a pity that their exchange did not continue and this remains anecdotical of this particular dialogue. Now, it is possible to explore the political dimension of thou-ing.

\section{9- Freire, hooks, and Anzaldúa: Politics informed by love:}

While with Carl Rogers explored the micro dimension of love and Buber provided a philosphical frame to sustain it, I believe another important reflection is which sort of communitarian relations and politics can be informed by love. I consider that Buber sought precisely this through his religious tradition, though I shall explore a more secularized approach. Here, my intent is both to devise the shape of love politics and to offer images of how love has manifested in the everyday life of three scholars from different contexts, but marked by suffering and oppression.

A personal struggle of mine relating to the term politics is the fact that I feel the term politics has become so infused with power struggles and social control that it distorts the meaning I would like to maintain: following Aristotle, politics means the concern for the well-being of a polis' citizens ${ }^{8}$ (Shields: 2016). Such a concern would translate into laws and ultimately, a constitution that would code the ethical conduct, but this is problematic inasmuch as it refers only to the citizens of the polis, and also crystalizes political action into a few determined laws. The sense of the term politics I would like to retain is the concern for the well-being of the citizens, which lead to taking actions that

${ }^{8}$ In Greece, at the time of Aristotle, citizenship was certainly not universal and was conferred only to men after their 21 st birthday. Yet I take citizenship as universal - any given person is a citizen. 
reveal our humanness, and which does not necessarily become final laws or modes of behaving - or at least remains always open for continuous review and change.

I consider the intent of shifting from the interpersonal approach of Rogers towards a community (in the political sense mentioned above) an important step because it provides a coherent shift from the love-action in the micro-relations towards the macro-level, as I feel it might be rather easy to fall into a trap of dismissing one's commitment and responsibility to love on the grounds of unfamiliarity with others, despite insights from Buber and Levinas when it comes to alterity. This is most relevant in a context where loving human relations are suspended by certain boundaries. Love not only connects and suspends boundaries, it also asserts, as Maslow mentions, that there are certain needs that must be taken into consideration for a human being to become able to explore his ability to love in full potential. Coming from Latin America, despite the incredible richness and diversity of the region and its cultures, poverty and inequality have undeniably influenced people's well-being. Thus, engaging with them and understanding how their lives can be transformed, and one's participation in it is a pervasive issue. In this way, love manifests in the wish to see people unfold their potential with dignity.

Starting close to home due to my Brazilian background, Paulo Freire is the first scholar whose work I would like to highlight, with particular regard for his concern over liberation and understanding the conditions of lack-based suffering. Paulo Freire was born in 1921 in Recife, Northeastern Brazil, one of the poorest regions of the country, and was felt deeply for the struggles of his people. As an educator and pedagogue, Freire put a significant effort on the "conscientization" of people's drive to self-growth and thus which contexts subdued it, and how this conscientization becomes a practice of freedom. Freire considered that such process took shape through fostering one's critical capacity, with support of a critical pedagogy. 
Strongly influenced by Marxism, Freire aimed at freedom from oppression, but whenever he spoke of liberation, he spoke of humanizing people, casting a gaze of love to those who he assumed could be the agents of their own change. For Freire, such a change could occur through a dialogue in which dialoguers would be transformed and humanized, breaking away from a "banking system" in which dialogue was reduced to a monologue and the assimilation of elitist perspective by the oppressed, calcifying inequality and marginalizing of human beings.

Dialogue is Freire's first approach into knowing human beings, as it represents for him an existential necessity. Dialogue is "the encounter in which united reflection and action of the dialoguers are addressed to the world which is to be transformed opens space for transformation and the commitment towards the voiced oppression one undergoes" (Freire: 2005, p.87). But dialogue cannot exist without a profound love for both the world and human beings. "Love is at the same time foundation and dialogue itself" (Freire: 2005, p.90).

Freire's structural approach must be regarded in light of his background and his concern for a philosophy of liberation. Its aim is breaking away ignorance and leading to a connection between human beings that fosters liberation and independence. This liberation and independence should not be distored by individualism, but rather to the commitment to the relations of fellow human-beings which cannot eve be eluded. "The act of love is commitment (...) and this commitment is dialogical. (...) If I do not love the world - if I do not love life - if I do not love the people - I cannot enter into dialogue (Freire: 2005, p.90).

Moving from Paulo Freire's thought which originated in South America, I would like now to highlight the work of bell hooks, within North America. bell hooks is an African-American feminist social activist and writer born in Kentucky (United States) in 
the fifties. hooks was raised in a caring family environment, which she also considered dysfunctional due to shifts into regular aggressive and humiliating relations (hooks: 2001, p.5). hooks also grew up in sexist and racially segregated United States. During her education and academic career, hooks was confronted due to both her color and gender, and these life experiences led hooks to a commitment to a politics of liberation from the systematic oppression she experienced, clearly influenced by Paulo Freire, and also by the activism of both Malcom X and Martin Luther King Junior, representatives of the civil rights and black people's movement in the US (European Graduate School, 2015).

Writing on the intersections between race, gender and class, hooks makes a poignant critique of the relations between capitalism, patriarchy and white-supremacy. In her major work Ain't I a Woman? (1990), hooks notes that during the black liberation movement, black male activists expected their black female counterparts to assume a subservient position to them, fading into the background. At the same time white feminism dismissed the accounts of black women by assuming that black women were strong enough to endure invisibilization (Hooks: 1990, p. 6-7), invisibilizing black female struggles. The interconnections of both race and gender become more complex as hooks analyses that black females have been suited for household work which is not perceived or recognized as a valid job, therefore introducing a layer of class (hooks: 1990, p. 91-92).

However, hooks does not remain solely in the fierce critique of the capitalist, sexist, white-supremacist cultural context in which she lives. Through the analysis of her family environment and a reflection on how to address her culture and her personal life, it was through love, through her heart, that hooks found an incredible source of power to inform and motivate her transformation and the transformation of the society in which she lives. When teaching critical thinking (influenced by Paulo Freire), hooks notes that for the inner light of her students to shine, she likes to engage their minds and hearts (hooks: 2010, p.20) 
in order to discover their uniqueness. Also influenced by Thich Nhat Hanh, hooks' political pedagogy is filled with compassion.

Inspired also by Erich Fromm, hooks felt the need to define love for contemporary society. Because she notes the poor dictionary definition, the popular culture plagued with romanticism and the sloppy definition of the term by some authors (hooks: 2001, p.3-4), along with the cynicism of a generation that does not seem to believe that there is such a thing as love, hooks comments on her long quest into a definition that resonated with her heart. hooks also mentions the fear of defining the term, due to a strong necessity some have to cling to relationships that are not filled love but which they are afraid of losing. hooks finally settles upon a definition of love following M. Scott Peck's The Road Less Traveled, published in 1978, "the will to extend one's self for the purpose of nurturing one's own or another's spiritual growth" (hooks: 2001, p.4). Following this, hooks explains that love is an act of will, requiring commitment and determination; within this context, spiritual growth does not have to be read as indeed spiritual but as a life principle that animates human beings (hooks: 2001, p.13).

One fundamental point of hooks, however, is (also following Scott Peck), differentiating love from cathexis. hooks considers cathexis a very common mistake people make. She notes that learning faulty definitions of love make it difficult for people to realize what an actual experience of love entails. Cathexis can be understood as the personification of love into a single being, a form of attachment that does not allow this person to be free but requires her to be connected to another, hampering one's unfolding process (hooks: 2001, p.6-7). A different form of cathexis would be the dependency of the relationship parents and children have. For hooks, abuse and neglect deny the existence of love, while love can offer an environment of nurturing discipline without punishment. 
For bell hooks, love presupposes seeing all beings as free and deserving of our reverence for the fulfillment of their lives. Highlighting this connection in which one is willing to foster another's process of unfolding in turn requires radical changes for it to become a social process. This change presupposes that no person can be ruled out and that one's own life is intimately intertwined with everyone else on this planet (hooks: 2001, p.87). That is why hooks' activism is so persistent. In her quest for a freedom that allows love to shine through, addressing the disharmony of contemporary society is a must. bell hooks offers a blueprint for a politics informed by love.

Remaining in North America, the next author I would like to highlight is Gloria Anzaldúa: A Mexican-US-American writer and philosopher that grew up in a family of farmers in the South of Texas. In her life, Anzaldúa struggled with a particular hormonal condition that made her different from other kids by having her puberty at the age of 6 . She was mocked by her teacher for being a native Spanish speaker instead of English in a segregated school in Texas. She struggled with financial vulnerability after her father's death, having to work to support her family, and endured racism and misogyny in her work life (Keating: 2014). Anzaldúa's history cannot be glossed over if we are to understand the power of her heart's voice. I find it extraordinary to see how a wounded heart can sparkle so much consciousness and love.

In Borderlands - La Frontera (2007), Gloria Anzaldúa explores the tensions of being a mestiza in the borders between Mexico and the United States. As a chicana and a lesbian, Anzaldúa roams around the territories of struggle between national, cultural, sexual and gender identities and the collisions thereof.

Because I, a mestiza, continually walk out of one culture and into another, because I am in all cultures at the same time, alma entre dos mundos, tres, cuatro, me zumba la cabeza con lo contradictorio. Estoy norteada por todas las voces que me hablan simultáneamente (Anzaldúa: 2007, p. 99). 
Anzaldúa does not get lost into just one voice and reacts out of it. In listening to all voices, she responds in an authentic and empathic tone, from her heart. "At some point, on our way to a new consciousness, we (...) see through serpent and eagle eyes (p.100)". Anzaldúa believes that the work of the mestiza's consciousness is to break down divisions that separate her from otherness in the most reified social forms, a perspective that can easily be translated into compassion and love. Having compassion does not render one devoid of critical reflection. Anzaldúa demonstrates that the subjective capabilities to reflect and from intuition select the good and the bad seeds of corn to grind and mix them into tortillas, which will be seasoned according to one's own preference. Making the same, but differently: still making tortillas, but in one's own way. At the same time, the very celebration of mestizaje in Mexico, which is Anzaldúa's focal point, has been particularly criticized as a form of silencing the debate around Mexicans of African heritage, which is made even more difficult as Mexico does not even include race in their National Census.

What I believe is most remarkable in the work of Freire, hooks, and Anzaldúa is how their compassionate hearts shine through not necessarily only after but amidst the most abject and difficult conditions, a situation that cannot be glossed over with an acute and critical understanding of the problems their kin suffered. Their heart and their love entered in full potential mode through facing the difficulties life imposed on them. In contexts where pain and dehumanization would lock understanding into a survival reaction, their hearts provided a way to respond to their experiences of suffering poverty, racism and discrimination, and worked on transforming their contexts into a space more conducive to the personal unfolding of human potential.

\section{0- Vattimo's Weak Thought as Freire's dialogical approach:}


In order for a connection of hearts to take place, for the act of love to become manifest, Freire proposes the form of a dialogue. I believe that for a successful dialogue certain conditions must be met: a dialogue presupposes the openness to empathically hear and respond to the speaker. It is through the consciousness of the particularity of my own perspective that I become able to both express it in a non-imposing way, as the sole means to interpret issues, and also allow others to have their say (based on their own perspective).

In this sense, the philosophy of Gianni Vattimo, based on the concept of Pensiero Debole (weak thought) becomes a very important approach for the heart to consider: "weak thought is also eminently an attitude towards things, whether ideas or relationships, predisposed to listening to the world, to the other being with whom I cannot but forever bewith" (Carravetta in Vattimo, Rovatti \& Carravetta: 2012, p.29). Gianni Vattimo is an Italian philosopher who, through the concept of weak thought, tries to respond to what he deems the twilight of modernity, as he writes from the very core of European modern thought. In the introduction to Vattimo's Weak Thought, Peter Carravetta explains that Vattimo's philosophy criticizes an overarching metaphysics that issues from the future the answers to our current concerns, pointing that we should presently find viable options for what remains of being and living. Considering our finitude, Vattimo seeks to give a possible account on the present, in a way that escapes both the naiveté of assuming there is such a thing as a new start and the denial that we live in a world of relations (Carravetta in Vattimo, Rovatti \& Carravetta: 2012, p.4).

With the awareness of how ideology shapes one's interpretation of the world, Vattimo focuses his concerns on dialectics as a form of engaging with life and thought in the face of difference. Following Hegelian logics, in which a thesis is confronted with an antithesis and both are assimilated into a synthesis, Vattimo perceives the idea of totality and appropriation of the synthesis are "forms of self-reassurance for epochs in which 
technology and social organization failed to render us capable of living in a more open horizon" (Vattimo in Vattimo, Rovatti \& Carravetta: 2012, P.43). In terms of dialogue, this self-reassurance, understood as the persistence to see things in one's own way, is the first element that needs to be removed if one is to fully engage in listening to one's counterpart's narrative.

But even if the dialectical process can be switched off towards an open horizon of plural theses, one rests with the matter of how to engage with any of the different theses in a non-assimilatory way. To this, Vattimo points out that the Heideggerian term Verwindung, as both taking account and taking leave of a topic, twisting it onto a possible understanding at a given moment, while acknowledging it too shall fade. Then again, the matter of difference within Beings themselves does not necessarily entail harmonious living. This is why, for Vattimo,

the enfeeblement of (the notion of) Being, the explicit occurrence of its temporal essence (which is also and especially ephemerality [...]) has serious repercussions for the way we conceive of thinking and of the Dasein that is its "subject" (Vattimo in Vattimo, Rovatti \& Carravetta: 2012, p. 45)

Twisting, therefore, is an approach to life that somewhat close to a responsible and possible understanding towards difference in the light of the transience of life. The feeble, weak Being on his weak thought therefore, calls for Pietas, suggesting a compassion for the finitude of life. Compassion is, following Fromm, a fundamental aspect of love.

In the light of Vattimo's thought, it is true that Freire's thought is affected by a Marxist interpretation of life as materialistic oppression, but this did not discourage Freire from the commitment to liberation and humanization that is analogue to pietas as proposed by Vattimo. Weak Thought allows for a humbleness towards a transitory and effectively frail life and allows people to also see that in the other and his/her account. It is an approach that moves with care and caution as well as a sort of kindness towards the encounter with otherness that is central in Fromm's awareness of the integrity of others. 


\section{1-An ethics of Love in Levinas and Thich-Nhat-Hanh:}

If Vattimo's main focus is an exploration on the ways one can think and engage with otherness within European postmodernity in the light of human frailty, Levinas follows a very similar path through the reflection of the care and responsibility - the ethics - that arise from the phenomenological event of the encounter with the other. Levinas is known for understanding ethics as a first philosophy (Peperzak et Al: 2008. p. 161).

Levinas was born in Lithuania at the beginning of the twentieth century from a Jewish family and, having seen both World Wars (including having been a prisoner during the II World War) and having seen the rise of the totalitarian regimes, develops a philosophy of being that focuses on the sensibility of being-for-the-other. A philosophy that is conscious of the violence of imperialism, colonialism and genocide experienced by his generation but that has an affect even up today.

The ethics that Levinas proposes, however, is far from an overarching moral commandment of how to relate with the other, and at the same time far from a cynical selfconsciousness of what comes to be one's most positive action manifest into utilitarianism. Levinas dislocates ethics from the egoic aspect of behavior or the righteous and politicized towards the face-to-face encounter. His ethics represent a moving towards the other, for the other, and manifests in the shape of peace and love (Levinas in Peperzak et Al: 2008, p. 166). In this sense, Levinas breaks with one's essence and towards what takes place otherwise than being: "If transcendence has a meaning, it can only signify the fact that the event of being, the esse, the essence, passes over to what is over than being" (Levinas: 2011a, p. 3). Thus, Levinas breaks away from the understanding of a monolithic self towards unicity and approaches a systemic thinking that informs the understanding of love proposed in this work. 
At the same time, Levinas underscores the plane of love: "we must indicate a plane both presupposing and transcending the epiphany of the Other in face [...]. This plane is that of love" (Levinas: 2011b, p.253). It so happens that love, for Levinas, would even contradict the transcendental experience of alterity towards the immanence of togetherness: "Love as a relation with the Other can be reduced to this fundamental immanence, be divested of all transcendence, seek but a connatural being, a sister soul" (Levinas: 2011b, p.254). This love also goes beyond the beloved approximating all human beings towards infinity, but never into totality, having to make itself anew and in different terms everyday, thus escaping a definitive moral commandment.

The ethics of love of Levinas is irreducible to such a totality: it requires proximity and a reconnaissance of the other. Such a reconnaissance into love implies an ultimate fraternal responsibility, putting into question limitless freedom and power: "Doubtless, responsibility for the other human being is, in its immediacy, anterior to every question" (Levinas in Peperzak et Al: 2008, p. 167.), and it is such an ethics of fraternal proximity that calls for an objective order of action.

This movement towards the other in Levinas is also described by Thich Nhat Hanh as inter-being, even though Nhat Hanh comes from a completely different accounting of reality, because in Buddhism there is not be the initial alterity that calls Levinas to engage and merge with, but only ignorance. According to Nhat Hanh, Inter-being is the sheer realization that no being is alone by him/her own self, and everything is in co-existence (Nhat Hanh: 1992, p. 95-96). Nhat Hanh states

"[w] hen we realize the mind of love, we have to go to the one who has been the object of our mindful observation, so that our mind of love is not just an object of our imagination, but a source of energy which has a real effect in the world" (Nhat Hanh: 1992, p. 84) 
This "going to the other", therefore, comprises the effort of realizing joy and happiness that penetrates everywhere. This similarly manifests in Levina's ultimate fraternal responsibility.

\section{2- Expressing love through Rosenberg's Non-Violent Communication:}

In the deep understanding and compassion of love, Thich Nhat Hanh notes that an attitude of deep listening and loving speech arises (Nhat Hanh: 2001, chapters 6-7). On the other hand, Marshall Rosenberg, has written extensively on Non-Violent Communication (NVC). Similarly to Levinas' ethics as a movement in between beings or Nhat Hanh's interbeing, Rosenberg states: "What I want in my life is compassion, a flow between myself and others based on a mutual giving from the heart (Rosenberg: 2005, p.1). Throughout his life, Rosenberg was mostly concerned with understanding what drove disconnection from a compassionate nature and what led people to behave violently. This questioning began after he moved to Detroit in 1943. Later, while pursuing his studies in psychology on disconnection and violence, Rosenberg identified "a specific approach of communicating - speaking and listening - that leads us to give from the heart $[\ldots]$ that allows our natural compassion to flourish" (Rosenberg: 2003, p.1-2).

According to Rosenberg,

NVC contains nothing new. It is based on historical principles of nonviolence - the natural state of compassion when no violence is present in the heart. NVC reminds us what we already instinctively know about how good it feels to authentically connect to another human being. With NVC we learn to hear our own deeper needs and those of others. Through its emphasis on deep listening - to ourselves as well as others- NVC helps us discover the depth of our own compassion. This language reveals the awareness that all human beings are only trying to honour universal values and needs, every minute, every day. (Center for NVC, 2019). 
According to Rosenberg, NVC is a process that has the components of observation, feelings, needs and requests. (Rosenberg: 2003, p.6-7). Observation without judgement of the environment or situation surrounding myself, clarity on the feelings one is experiencing in the situation, identifying the needs related to these feelings and, finally, making a concrete request regarding what could enrich oneself out of this situation. In so doing, one can express oneself honestly. The counterpart of NVC would be empathic and active listening, which focuses on the one who is speaking as well as the listener holding the space and being present. According to Rosenberg, behind every process of violent communication lies a tragic expression of an unmet need, and through empathic listening we respond to that need, filtering the violence and avoiding its propagation, instead of unconsciously reacting to it. Through music, Rosenberg manages to condense all needs in a poetic way, inviting a compassionate and loving gaze:

See me beautiful, look for the best in me

That's what I really am and all I want to be

It may take some time

It may be hard to find

But see me beautiful

See me beautiful, each and ev'ry day

Could You take a chance?

Could You find a way?

To see me shining through

In ev'ry thing I do

And see me beautiful

See me beautiful, look for the best in me

That's what I really am and all I want to be

It may take some time

It may be hard to find

But see me beautiful

(Rosenberg, 2002) 
By breaking down the process of NVC into steps, Marshall Rosenberg gets caught in a structural approach that fosters a mechanical repetition of steps that could loose its original meaning. For NVC to have an effect, it is important to stress the intentionality and the adequate means beyond the mechanical assimilation of NVC's language.

\section{3-Conclusions:}

I began this chapter analysing one's capability to love and how loving is a form of responding to and diminishing human suffering. Yet, before delving into love, certain clarifications on the heart felt necessary, as often love is associated with the heart, with feelings and emotions. I have differentiated love from feelings and emotions towards a more grounded perspective. Furthermore, in this work, I have made clear that the heart is to be understood as a metaphor to the act of loving (instead of assuming that the literal heart organ is the place where love is experienced), which is further supported by the idea of anahata in the chakra philosophy and in other traditions.

Love persists as a fundamental aspect of life that I consider essential for my everyday life, especially in the academic areas and practical work into which peace studies delves. While I remain distant from a closed and final definition of love, in this chapter I have elaborated a situated perspective that allows peace studies to be thought anew when integrating the perspective of love. I started with a consideration of what I originally understood as love, which was the commitment of fostering connections, nurturing humanness between people.

I then analyze the relations between my own perspective and the conceptualization of love in my cultural background. As a Westerner, taking Greek mythology as a parting point, I analyze the difference between Eros, Agape and Philia. The common element 
between them is that, although different in nature, all of them indeed stand for a connection between beings. If Eros is not realized in the relations between two or more beings, then love can also manifest either in the shape of Agape or Philia - again and always as a choice. In the Christian tradition, however, a break from these forms of love took place, so I examine Saint Augustine's prevalent understanding of love in the Christian tradition, which is that of loving God above all things, longing for joining Him in paradise (Eros) and distancing oneself from God's worldly manifestation. The Christian tradition, however, is also challenged by vernacular assumptions such as Francis of Assisi's, which focuses on the Agapean and Phillian aspect of love.

Meanwhile, the Cartesian influence over privileging reason and relegating those subjective aspects of existence into a lower realm has heightened reason as the essence of human life. Love then would be manifested on private grounds, being removed from one's public and political life. As this took place, reactions such as Romanticism took place within European society. Romanticism focused on feelings and emotions as love, and this seems to be the most prevalent assumption of love to date.

This leads to Erich Fromm's (1995) need to reflect on what effectively is love for him and how Western culture fails to understand it. Fromm frames love as an art that demands knowledge, effort and commitment, requiring practice and diligence towards mastery. Fromm also underscores how not all experiences of connectedness stand for love, as some relationships easily turn into dependence, which undermine the integrity of one's existence if physically separated. This is why Fromm posits that love is the paradox of two beings become one yet remaining two. Moreover, Fromm highlights that love is an acting of giving without expectation, unfolding this giving into care, responsibility, respect and knowledge. Fromm also highlights some different aspects of loving such as the compassion of motherly love, the desire for one to develop one's full potential as human beings as 
fatherly love and brotherly love as the expression of an individual in sync with his/her environment and human fellowship, honoring and respecting each and every one of them. The sublime experience of these forms of love unfold into the love of God which is a transcendental recognition of the sacredness of life.

As the choice of mastering an art is not an easy task, discipline is a necessary element into working into each aspect of love. Thich Nhat Hanh (2004) unfolds love into four aspects following Buddhism. These aspects are maitri, or loving-kindness; karuna, or compassion; mudita, or joy; and, finally, upkesha, which stands for liberation. The ability to remain present and entirely aware with both mind and body allows one to respond with love to many life encounters, honoring the connection between human beings, which in turn enfeebles focus on self that reinforces one's ego and narcissism.

For Maslow (2013), it is clear that while in certain environments the choice of loving is very hard, change remains possible with effort. The more one cultivates a loving attitude and thus slowly creates a nurturing environment, the bigger the chances of reaching a turning point in which love may become a common aspect, more so than the exception. It is a matter of catalyzing one's always existing potential. Along this vein, Carl Rogers (1977) develops his client-centered pyschoteraphy, which trusts a person's potential to unfold and love, This happens by the sheer choice of being present and attentive to one's needs, by voicing one's concerns, and by diligently and patiently accompanying one's selfhealing process. Through his practice and written research, On Personal Power, he explores the significance of motherly love, fatherly love, brotherly love and also maitri, karuna, mudita and upkesha.

When it comes to the extension of love towards the social realm, the politics of love seen in Paulo Freire, bell hooks, and Gloria Anzaldúa manifest through the effort of extending over others the choice of loving. bell hooks stresses that no person can be ruled 
out from the choice of loving, and she focuses particularly on the more vulnerable groups whose lives become fragile due to the layers of oppression that affect them, such as gender, race and class. In a similar vein, Anzaldúa does such a reflection from the perspective of a new consciousness. She breaks down the divisions that separate her from otherness in reified social forms by integrating her intuitive capabilities to make the choice of loving. Freire, on the other hand, commits himself to what Nhat Hanh has called upkesha or liberation through dialogue, as he sees that love is the foundation and the dialogue itself.

The shape that these relations take in practice must be an enfeebled manifestation of self in order to leave room for focusing more on the relations between beings. That is why Gianni Vattimo's weak thought (2012) becomes an important attitude in this dialogue, twisting history, twisting one's ideology in favor of the present relations, which are moreover called upon Pietas or compassion once again. This weak thought, guards relations with a certain kind of ethics. The ethics that the weak thought calls forth, however, does not respond to overarching metaphysical thought but prioritizes focusing on the phenomena of the encounter with the other, which is the core understanding of Emmanuel Levinas' ethics. This ethics represents yet again the choice of moving towards the other in an encounter that underpins unicity through proximity and reconnaissance, which entails an ultimate fraternal responsibility - that is also manifested in Thich Nhat Hanh's concept of inter-being (2001).

Lastly, in this chapter, I have framed loving through the choice of how to engage with others in a way that an ethics of love is present and turns into politics: that is through Marshall Rosenberg's Non-violent Communication, which focuses on the principle of nonviolence and an enlarged concept of communication that goes beyond what's said, focusing on the intentionality behind human relations, and the mindful effort of empathic and active listening, honoring the counterparts of maitri and karuna. 


\section{Chapter 2- Love in Peace Studies:}

Only a few persons and agencies have purposefully endeavored to improve in their own interactions this process of love production, or have devoted themselves to this task to a considerable degree. (Pitirin Sorokin: 1954, p.38)

\section{1- Introduction:}

In the previous chapter, I laid out my own conceptual approach to love. I present the ways in which a person can apprehend its manifestation through different aspects of life, particularly in some approaches towards inter-relations, politics, ethics and communication. Since all these aspects are of fundamental concern for peace studies, love becomes a considerably relevant part of peace research. Peace research, however, traditionally shunned love and any other subjective aspect of human relations due to its origins in the social sciences. Yet, its multidisciplinary nature and the recent transdisciplinary trend within academia has allowed peace studies to draw complex and relevant perspectives from areas such as philosophy and psychology; however, such a tendency of peace research to open itself beyond the social sciences is still shy with regards to considering love as a relevant aspect within peace studies itself.

Although an underexplored area, love in peace studies has not been completely ignored and, in this chapter, my purpose is to explore precisely how it has been addressed within so called peace research authors in order to catalyze the study of the relations between love and peace. Therefore, I have considered the works of authors that have explicitly defined their work as peace research, having either been a hallmark for peace studies or having directly written about love. The most interesting thing is that oftentimes, 
despite the fact that certain authors make little mention of love or to related terms, in the selected peace scholars of this chapter there seems to be a lot of agreement regarding the core aspects that I attribute to love and its relation to peace.

Aware of the impossibilities of covering all peace studies scholars in the world, the selection of authors for this chapter is in part related to the curriculum developed by the peace studies program of the Universitat Jaume I and its partner program at the Innsbruck University. The authors I discuss here are: Johan Galtung, Kenneth and Elise Boulding, Adam Curle, Francisco Muñoz, Vicent Martínez Guzmán, Wolfgang Dietrich and Pierre Weil. Therefore, the content of this chapter is to a significant extent geographically located in Europe. If I consider Pierre Weil an exception to this group, as he has not been part of the curriculum in both peace programs mentioned above, and he has conducted extensive peace research in Brazil, I must also take in consideration that he is originally French, maintaining a geographical coherence. Despite John Paul Lederach is not European but US American, his work has been extensively discussed in the Peace Studies Programs in Castellón and Innsbruck. Moreover, I consider North America close enough to Europe in cultural terms.

In a way, these cultural/geographical considerations are important because in this group of authors I perceive a common response to a purely modern-rational, cognitive aspect of peace research, and the need to react to this modern mode of operating becomes feebler with time, allowing love to become a less questioned matter in peace research if compared to other social sciences.

\section{2- Johan Galtung: Blueprints for (love in) Peace Studies:}

It is hard not to approach peace studies without referencing Johan Galtung. Of course, peace has mattered to humankind much earlier than it had mattered to Galtung in 
the twentieth century. Still, Galtung is considered the founder of peace studies for having created the first institution dedicated to peace research in the world, having founded PRIO (International Peace Research Institute Oslo, in Norway), which soon led to peace studies graduate programs over the world. Born in Norway during the period between World Wars I and II, Galtung saw his father being taken to a concentration camp during the Nazi occupation of Norway. Perhaps due to such an experience of war, Galtung developed an interest in the topic of peace and peace research, but found out that at this time there was no such material. Ever since, Galtung has done an unprecedented effort of combining an academic research on peace with the practice of mediating conflicts. Galtung coined some of the most commonly held concepts in peace studies, such as peacebuilding, negative or positive peace, and the notions of direct, structural and cultural violence. He has also developed a conflict transformation method known as Transcend inspired by the medical approach to health, based on Diagnosis-Prognosis-Therapy, but focusing on the dialogue established by parties on their several levels (Galtung and Fischer: 2013). Although the Transcend method is referred to as a conflict transformation method, through a careful use of the terminologies conflict management, conflict resolution and conflict transformation, the Transcend method should fall into the conflict management category.

It is hard to select and organize Galtung's publications in one coherent whole. Although Galtung himself does not acknowledge phases in his life (Tortosa: 1995), there are shifts from approaching topics related to structuralism and imperialism to approaching topics closer to culture and spirituality. Accordingly, he notes that his concept of peace has varied from the absence of violence towards that situation in which conflicts can be transformed non-violently (Tortosa: 1995).

Galtung, however, has not written extensively on love. On a book with Dietrich Fischer, Galtung considers love simply as a metaphor for peace in which love, representing 
the union of body, mind and spirit, or the "union of those unions" would lead to a "positive relations between parties" (Galtung and Fischer:2013, p.151). Yet such a definition lacks the aspect of will to love that one practices in order to first acknowledge those unions so it can eventually unfold into positive relations. Moreover, as an act of service, love has to be open for debate and interpellation between lovers. Despite Galtung's equivalence of love as positive peace, he eventually comes to acknowledge that active love is a fundamental aspect of positive peace (Galtung and Fischer: 2013, p.174), implying the effort necessary in this art of loving, as Fromm would consider.

Still, the question of whether or not love can be manifested in conflictive environments and catalyze their transformation remains unsolved in Galtung's approach because love would only manifest within those "easier" environments of positive peace. Although Galtung's definition of love could deserve more attention, Galtung has set an important precedent for understanding the relevance of love as a more fundamental aspect of human relations towards peace in peace studies. Such a precedent appears more strongly in his book Peace by Peaceful Means, first published in 1996, where he dwells on an epistemological basis for Peace Studies. Because peace studies follow general rules for scientific research, as intersubjective communication, Galtung highlights that peace studies' values must be open to public scrutiny (Galtung: 1996, p. 9). If I take love and loving as a value, it is ultimately this excerpt of Galtung that allows me to access the relevance and even presence of love within conflict transformation and positive peace.

Following his reflection on peace studies, Galtung has proposed a tripartite division to it, in which peace studies could be differentiated between an empirical, a critical, or a constructive approach. In the constructive approach, Galtung mentions the importance of contrasting theories (on human relations) with values, in which theories do not remain only explaining reality, but are committed to approaching those dissonant aspects of the reality 
in accordance with clearly stated values for a change - avoiding the trap of remaining at diagnosis or pure criticism. But Galtung notes that the apparent objectivity of these values only happen through inter-subjectivity (Galtung: 1996, p. 15).

Over the matter of theoretical framing(s) for peace studies, Galtung proposes a theory that seeks to overcome dichotomies, towards a unitary and more complex understanding of relations. He proposes this through a shifting from a Manicheist perspective of human relations (and conflict) towards a Daoist postulation of interconnectivity and unity of complementary polarities while remaining at the same time unique.

In the light of these reflections, how can these epistemological bases that Galtung proposes for peace studies bring the need of understanding love in a deeper way? Galtung has highlighted the need for peace studies to open up to public scrutiny its underlying values, values that are to be translated into objectivity through the explicitness of intersubjectivity, and which support theories that dwell on the experience of connectivity and unity. Without dwelling on love, Galtung has made it possible for the necessary architecture of love to be discussed within peace studies, deepening his own reflections on the role of love within conflict transformation and positive peace within a scientific approach.

\section{3- Kenneth Boulding:}

Kenneth Boulding, a U.S. American economist born in England, has been considered a pioneer of peace research due to his involvements with the the foundation of The Journal of Conflict Resolution in the 50s. In 1945, Boulding joined the Society for General Systems Research. Combining his economics background and his interest in systems theory, Boulding approached the matter of conflicts through the lenses of economic 
behavior, mathematical models, games theory, which culminated in the book Conflict and Defense: A General Theory of 1962. Thus, Kenneth Boulding's research is not exactly peace research, or, better framed, is dedicated more to negative peace.

But Boulding's interesting contribution to the matter of love (and its relation to peace) resides in The Economy of Love and Fear - a Preface to Grants Economics published in 1973. Picking up on the lack of research regarding the elements of a social system that either led to conflict understood in positive terms (as in impasses that made possible understandings and dialogue), or negative term (leading to destructivity), through the analysis of capital, or capital transfers, Boulding started paying attention to a part of the economy that is often overlooked in traditional economics despite the fact that it comprises an important dimension of economic activity: the economics of grants. Boulding argues that grants are considered an exception to economics because they do not entail exchange or expectation of getting something in return. Thus, Boulding considers that grants could be conceived as a donation, which entails nurturing aspects of social relations and, ultimately, of love. At the same time, Boulding is also aware that grants could also be conceived of as tributes, being led by fear and obligation. Often, capital transfers in the form of grants can be of a mixed nature: being led by both love and fear. In any case, such a perspective could be further attested to by the fiscal system (Boulding: 1976 p.17-18).

Nonetheless, Boulding's understanding of love cannot be reduced only to a subjective state that lends itself to material and capital fluxes. Boulding's argument is that love is a fundamental aspect of any systemic balancing towards peace. Thus, a shift from an (economic) system that is based on fear, exploitation and inequality, towards an economy in service of enabling others to unfold their capabilities requires a compassionate relation to one's peers. This leads him to comment on Stable Peace (1978), the idea that "peace signifies a condition of good management, orderly resolution of conflict, harmony 
associated with mature relationships, gentleness, and love" (p. 3). His research thus points to the need of addressing the matter of will and love into human relations in more detail, expanding the peaceness of a system.

\section{4- Elise Boulding:}

Born in Oslo, Norway, Elise Boulding emigrated with her family to the U.S. at the age of three. She came to be one of the founders of the International Peace Research Association and is considered a trailblazer of positive peace research and important peace activist. Elise has written extensively on the role on how women, family and spirituality are central aspects to peace research, in a way inaugurating positive peace research. Besides that, she also contributed to and supported Kenneth Boulding's research, who also happened to be her husband. In fact, their research complement each other because both placed emphasis on eliciting and highlighting overlooked peace perspectives - either in sociology or economics.

As a sociologist, Elise sought to make visible a hidden side of social relations, which were all too often overlooked but that fostered the idea of peace. In Cultures of Peace The Hidden Side of History (2000), Elise compiles her research challenging the idea of history at sword's point, as history is often conceived in terms of wars, power and violence. She explains how such interpretations of history have dominated the history of human caring, compassion and reconciliation and have thus dominated the sense of what it means to be a human being (Boulding: 2000, p.11).

Elise Boulding has not written about love. Yet the culture of peace she advocated for in the form of the recognition of women in The Underside of History: A View of Women through Time (1976), in the form of spirituality through Into Full Flower: Making Peace Cultures Happen (2010, written with Daisaku Ikeda), and in the form of retrieving a hidden 
history of peace fostered a world in which love was considered a key aspect in human relations.

\section{5- Adam Curle: The Role of Love in Conflict Transformation:}

Born Charles Curle in l'Isle Adam, a village nearby Paris, France in 1916, Curle adopted his first name from his birthplace, becoming known as Adam Curle. Much of Curle's concern over peace was instilled in him by his mother, who had lost three brothers to war. After he earned a degree in Anthropology from Oxford and served the British army during World War II, Curle started working at the Tavistock Institute of Human Relations in London, focusing on the resettlement of former war combatants who were held as prisoners during war. After this experience, Curle juggled work both as an academic and conflict mediator. He held teaching and research positions in countries such as the United Kingdom, Ghana and the United States, in the areas of social psychology, education and development. Meanwhile Curle was actively involved in conflict mediation as a track-2 diplomat, ${ }^{9}$ in countries and regions such as India-Pakistan, Nigeria, Northern Ireland and the Balkans. Influenced and supported by the Quakers Society, who in 1973 helped Curle establish the Bradford Department of Peace Studies (Woodhouse: 2006 and 2010). Thus, Curle became the first professor of Peace Studies in Europe.

The scope of peace research carried out in Bradford under Curle's auspices was provided mainly by his academic interests in psychology and development and the influences of theology and philosophy. It is interesting to note that Curle's thought was considerably influenced by that of Paulo Freire's while both were at Harvard University, US. This relationship can be further attest to his use of the expression liberation in diplomats.

${ }^{9}$ Track-2 diplomacy is also known as citizen's diplomacy and is carried out by non-official 
education. Curle's research involved an understanding of peace as that situation achieved through liberating human potential in all their dimensions, and as such already also contained the subjective dimension of peace studies and research that Galtung came to mention later on in Peace by Peaceful Means in 1996. Combining other well established academic areas and following Curle's own understanding of peace, peace studies at Bradford came to focus on a few different strands of activities such as: the critical analysis of the war industry, violent political regimes, and international institutions; an analysis of social movements related to peace; and conflict mediation as a component of peacemaking (Woodhouse: 2010).

Even though at Bradford Peace Studies they discussed the topics mentioned above, Curle understood peace studies as the combination of the following: (humanistic) psychology - due to his own work experience dealing with the affects of human violence; development studies -as a mindset that has produced a great number of conflicts in the places he worked (namely Nigeria, Pakistan and India); and, also anthropology as lenses that could envision and nurture cultures of peace. It is both interesting and important to notice that psychology and anthropology - the main components of peace studies for Curle - pose a fundamentally different epistemological approach to peace, conflict, and violence compared to International Studies: namely, the realization that wars and violence derive from human psyche and actions in any given fostering culture versus the assumption in International Studies that abstract entities such as countries, international anarchy, and any other human creation, create war and violence (and peace).

As a peace scholar, Curle was the first to actually dedicate an entire book to the matter of love and its relations with peace. In The Fragile Voice of Love (2006) Curle explores his understanding of love and its role in peace. In order to approach that matter, The Fragile Voice of Love, Curle makes a few preliminary explanations on the ontological 
assumptions made in the book. First, Curle defines what he calls "the mind of the universe" as a force that does not equate to a God as commonly understood in the Christian, Jewish or Muslim tradition. For Curle, the mind of the universe is a divine essence infused in all things that exists and a force that unites everything. ${ }^{10}$ Such unity would allow distant bodies in the universe to relate. Second, Curle draws attention to the "black cloud" as a "compound of fear and misery (...) distilled and expelled by suffering humanity in the form of sad and muddled feelings (...) [a] negative state of mind spread throughout much of the population" (Curle:2006: p.1). Among these two dwelling forces, Curle takes into consideration the human factor as an intermediator of both forces, mentioning human beings as equipped with potential both for perfecting ourselves and attuning to the mind of the universe... or getting lost within the black cloud.

In The Fragile Voice of Love (2006), Curle is concerned with "how we live, or love, or cope with the world" and how through our action we tap either into the mind of the universe or the black cloud. Curle chooses to address his concern with love through narratives that make explicit precisely that which is the nature of love and how it becomes a bridge towards the mind of the universe, amidst situations in which the black cloud becomes thick enough to threaten one's life, emerging from misery, fear and anger. Curle's argument is that often the voice of love provides the opportunity towards the way out of the black cloud. Albeit powerful, it is a very subtle nature and requires one to be quite attentive to the moments it shines through. Curle underscores that love, compassion, courage and generosity are the gifts of the mind of the universe to humanity and provide the key to how one can engage with their life towards channeling the mind of the universe

${ }^{10}$ Curle is adamant in differentiating the mind of the universe from God mainly because for him human action should not be one of pleasing God, as often this action could still be carried out reluctantly and halfheartedly. For Curle it is a matter of attuning to the mind of the universe and acting through it towards ultimate wholeness and liberation/emptiness. This eventually draws him very close to Buddhism. 
and experiencing wholeness/emptiness, undoing the black cloud that is produced by human unawareness.

"[T]here are certainly cases when a man or woman of clear mind and exceptionally good heart will wish to live with and bring comfort and solace to someone quite incompatible" (Curle: 2006 p.26). In such a situation, Curle points to the very will of engaging with others aware of the gifts that the mind of the universe has provided human beings. Love and compassion can show how the black cloud starts growing inside someone - or prevent it from growing through the awareness that whenever one thinks, the brain physically produces a neuronal electric discharge that gets strong the more often it repeats itself. The more one thinks negatively of someone, the more s/he feeds this neuronal connection and the more of a habit this thinking becomes due to this strengthening connection, to the dismay of connections that provide healthier thoughts tapping into human potential. That is why to live with incompatible people is often a task of a high order, to exercise one's love synapses whenever it seems so unlikely or difficult. Courage and generosity refer directly to the paradoxical effort and joy within this attitude. The very difficult uttering of words that refer positively to someone we find ourselves compelled to dislike, become a powerful first step into de-articulating the process of feeding the black cloud, as ridiculous as it may sound, just as much as a verbal habit slowly becomes a patois (Curle:2006 p. 34).

Curle also highlights the fact that contemporary society seems to assume that financial affluence somehow facilitated happiness and love, particularly after the carnage of the World Wars. To be rich became the answer to living. According to Curle, this misconception on how to live tapping the mind of the universe democratically affects both rich and poor: the only way to engage with the world is through consumption. While now many more people are able to afford what was before a luxury available to only a few, 
citing for instance jet travel, smart cars, Curle points that this fantasy of becoming richer by consuming masks the misery and the wider gap between the rich and the poor, and it masks the fact that the more we consume as a way to feel satisfied in this world, we deplete it some more. Furthermore, it creates envy and greed which in turn become motifs for warfaring (both in the literal and figurative conceptions) for resources.

Still, there are ways to address addictions of this sort through the rehabilitation of torn social tissues by the commitment of providing meaningful and touching examples of meaningful and engaged lives with one's peers and community. Curle illustrates this by citing the reintegration of former soldiers through Civil Resettlement Units, people uprooted from their context and forced into a hostile and violent environment, having imprinted many of the horrors they saw during war, benefited from a slow process of reintegration. While it could not prevent violence, it seemed to give former soldiers more resilience to deal with and respond to quarrels and hostilities in a constructive way and reduce the number of cases in which intervention was necessary, whereas those not undertaking this reintegration have demonstrated more difficulties in relating with their communities. Here Curle shows that the care and respect that love entails channels the mind of the universe into society, even though the black cloud may always creep around it.

In Curle's thinking, his commitment to the human being is expressed in this undeniable connectivity that can provide the possibility for peace and conflict transformation via love, or how the illusion of separateness feeds into the collective shadows bringing about misery. That is why Curle stresses the choice of engaging with violence or what would be labeled as violent people or violent places with love:

"the more peacefully and lovingly we live, the more we will help our neighbours to do the same. If we can bridge the gap between each other's communities, the more we will detoxify the poisons of fear and hatred, the more we will calm the miserable 
desperation of the black cloud, the closer we will come to the peace of the Universal Mind, and the sooner shall we be lost in its embrace" (Curle: 2006 p.45).

With personal stories in places like Ireland during "the Troubles", South Africa's Apartheid, or the Sri Lanka's Civil War, Curle illustrates his work countering disconnection and violence, setting the ground for reconciliation, even if violence might have prevailed in some of the places he was working. Still, those remain examples of a choice of action that fosters an understanding and potentiating peaceful life through nourishing the fragile voice of love.

\section{6- Francisco Muñoz: Peace as reference:}

Born in the late 50s in Granada, Spain, Francisco Muñoz became a History researcher and teacher at the university that takes the name of his hometown. Muñoz dedicated most of his research to unveil a historiography of peace. He reached the conclusion that, peace is more so the norm in human history rather than the exception. He parts ways with Karl Marx in Marx's assumption that violence is the 'midwife' of history (Muñoz \& Jiménez: 2012 p.7). In the first decades of his life, Muñoz experienced a time in which Franco's dictatorial regime in Spain was slowly coming to an end, a period in which a certain "emancipatory violence" seemed at times an alluring approach towards a utopian, more just and more peaceful society, albeit the obvious disagreement between violent means and peaceful end-goals (Muñoz, 2001 p.8-10).

In the late seventies and early eights, Spain entered a gradual transition into a democracy after the violent and repressive policies of Franco. Francisco considers that this transition substantially changed Spanish people's concepts of freedom, politics, law, habits and ideologies, in which the appeal of violence in order to become a more liberated society was not needed. It was a time in which the history of peace could be uncovered and also a 
time in which new social movements such as the ecological, feminist and pacifist movements could flourish (Muñoz, 2001 p.8).

In 1990, after getting to know Johan Galtung through the International Peace Research Association Congress in Gröningen, Netherlands, Muñoz had become familiarized with Galtung's concept of structural violence, which he found in contrast with the epistemological and ontological potentials of peace research (Muñoz, 2001 p.9). For Muñoz, despite the fact that structural violence was a strategy to denounce the violent aspects of society that required attention, it presupposed a continuation of the understanding of human nature and human history as predominantly violent. Therefore, human history and the reflection onto human life required a fundamental "epistemological turn" (Muñoz \& Jiménez: 2012 p. 14), which meant breaking away from such violence-centered approaches towards making peace visible.

Muñoz has come to understand that the fundamental base of what moved history were conflicts. For Muñoz, conflicts did not need to be interpreted as negative. Conflicts were simply the "coexistence of possible divergent projects" (Muñoz \& Jiménez: 2012 p. 47) that called for a creative search for solutions. Hence, conflicts were neither necessarily nor factually violent, and Muñoz considered that most human conflicts are regulated rather peacefully: "las experiencias pacíficas, de intercambio, cooperación, solidaridad, diplomacia, han sido dominantes en la Historia" (Muñoz \& Jiménez: 2012 p. 53). For Muñoz, peace is a silent and discrete pillar of human interactions, above all in the Mediterranean, the area in which he focuses. It is important to note that Muñoz concentrated his analysis predominately on Western history in combination with Islamic thought, considering that, at least geographically, Islam appeared in the same region as Judaism and Christianity. Aware of this limitation, Muñoz understood that if peace is a discrete but 
always present aspect in human history, then we need a peace historiography, providing evidence of peaceful regulations of human relations.

For Muñoz, this research allowed him to propose not only a new anthropological model but also a new ontological model by making evident the Western fixation with violence, from the stigmatization of an original sin to a Hobbesian conception of the world towards a perfectly regulated state in which there has always been an unsurmountable clash between two opposing forces of good and evil. For Muñoz, this Manicheist conception of humanity is problematic because it does not take into account human potential and capacities to learn and change, even if much of human predisposition is influenced by repetition of patterns of behavior. This account of human potential and capacities opens up space for a new model of humans in which we could release ourselves from the violent backlash reactions we have inherited (Muñoz \& Jiménez: 2012 p. 40-49).

In Muñoz's views, this called for a reflection on human actualization. In terms of human actualization, Muñoz highlighted the lack of political and intellectual attention to non-violence, the conscious effort of not resorting to violence as an immediate response to one's issues. Non-violence, a human ability to transform conflicts, is all the more backed by the peace historiography he proposes in La Paz, Partera de la Historia (2012) and Historia de la Paz, Tiempos, espacios y Actores (2000). Among these abilities are mediation work and pacifist empowerment. Such pacifist empowerment stemmed from the consciousness of one's freedom and responsibilities of making a choice that catalyzes peace - be it on a bodily level, cognitive emotional level, and also on a mutual, communal and transcendental level. For Muñoz love represents this consciousness at work precisely to transform stances of violence, stances in which the imperfection of peace becomes evident and calls forth a meaningful response. 
At this point, Muñoz introduces love as a major element in (peace) history. The roles of altruism, solidarity, cooperation, kindness, tenderness, friendliness, hospitality as soft aspects of love have been present throughout processes of socialization from the familial to the tribal, to the communal, and the social. Even in more complex and large societies, this primal call has led to the institutionalization of those service intentions, even though the hardening of institutions often diluted and lost its original purpose. Muñoz understands love as a concept that synthetizes all these vital practices, and also that love is represented in the feelings, emotions and intentions that call life forward (Muñoz \& Jiménez: 2012 p. 58), becoming a source of biopower to respond to the complexities of the world. This love-fed biopower still allows human beings to perceive their frailty in the light of a complex universe; however, for him, frailty did not mean weakness.

Although Muñoz unveiled another version of history, one in which peace has been prevalent despite the over-emphasized attention to violence, he still considered and did not deny the numerous concrete episodes in which violence has been a poor answer for regulating human relations. Aware of the human condition of imperfection and the many stances in which violence indeed broke out, Muñoz wanted to highlight the fact that peace is, therefore, imperfect. However, Muñoz referred to peace as imperfect implying not a fatalist sense of "there is nothing we can do", but as abcall for perfecting it, for making use of the human potential for peaceful regulations of life and its conflicts. For Muñoz, peace can be experienced, stimulated and put forth.

In this way, by making imperfect peace an analytical category, peace research would break away both from violence as the main topics of history and also with a utopian and idealist static future, calling forth action into forever perfecting and enacting peace (Muñoz: 2001 p.41-42). Therefore, Peace would turn into a continuous process, and peace 
research would tune into the search for new paradigms, new ways of knowing that would facilitate this process of living and making peaces. Furthermore, love would be one of them.

\section{7- Vicent Martinez Guzman: The philosophical backbone of peaces:}

Coming from La Vall d'Uixó, a small rural village in Spain and born 10 years after the end of the Spanish Civil War, a boy named Vicent Martínez Guzmán had to work from a very young age, first in a shoe factory and then in the Valencian orange industry. Martínez Guzmán endured significant social, political and economic hardship, and coupled with that the violence of Franco's Dictatorship (Forastelli: 2013). It is perhaps due to this that Martínez Guzmán, responding to the many forms of violence he saw and experienced, understood that despite all the harsh reality people experience, podemos hacer las paces, we can make peaces. Therefore, in order to delve into the "task of making peaces(s)" Martínez Guzmán looked for its epistemological and normative foundations through his studies in philosophy at the University of Valencia (Forastelli: 2013). During his formative years, Martínez Guzmán came to realize philosophy as the critical reflection of what humans do to one another, and thus followed Edmund Husserl's takings of the philosopher as a sort of servant to humankind. Martínez Guzmán's critical thinking over the way one relates to their peers is an act of compassion and awareness in itself.

For Martínez Guzmán, the task of a peace philosopher committed to peace as a framework is to philosophically rebuild such a framework vis-à-vis human behavior and an ideal. Despite the portrayal of his early life's environment as inherently violent, Martínez Guzmán understood that peace and conviviality were the rule of human experience, not the exception. The parallels to Francisco Muñoz's perspective are evident here. Martínez Guzmán understood that peace was a de facto realism, responding to the realist claims that 
violence is the essence of human nature. It was a matter only of making them visible, graspable.

The issue that unfolded for Martínez Guzmán became focusing on rebuilding the philosophical foundations of peace and re-espousing them with those empirical notions of peace that have always accompanied human experience. His task was to make sense of what we had inherited of humankind and what we were doing with this heirloom. For that, he found it necessary to become critical of ill-conceived philosophical reflections (such as Thomas Hobbes'), to become critical of the shortcomings of sound philosophical reflections (such as Immanuel Kant's) and to redeem those reflections, while being critical of how our deeds might be guided by either ill-conceived perspectives or the shortcomings of coherent perspectives on peace. This ultimately stimulated his philosophy and ideas with regards to the many ways of making peaces.

Through such reasoning on the many ways of thinking with and through philosophy, Martínez Guzmán understood that, despite their relevance, philosophy and reasoning have also become tools for domination. This became explicit in Martínez Guzmán' study of Immanuel Kant. Martínez Guzmán proposed a transkantian (with and beyond Kant) philosophy that was, in his terms, "a way of thinking also Kant contra Kant" (Martínez Guzmán: 1997, 2001). In this process, Martínez Guzmán is actually updating and reassing Kant for the turn of the twenty-first century.

For instance, in The Metaphysics of Morals Kant assumes that human nature is unredeemably conflictive, and that human reason should lead us to a legal and institutionalized system that regulated such conflictive nature, a system valid for all human reasons. But, against Kant, Martínez Guzmán rejects an inherently negative connotation to human nature and, while with Kant he endorses the positive aspect of legal frameworks that create or maintain peace. With Kant, Martínez Guzmán shares the idea that these 
institutions have to be publicly accounted for their agendas, so that human reason can assess their relevance. But, against Kant, Martínez Guzmán reflects upon whether or not institutions such as NATO and the Dayton Accords lead to peace or violence. Beyond Kant, with this argument he shows that it is not reason alone that calls for peace, but also the response to human suffering and pain, a type of peace that is different than reason as only a legal-oriented peace. For Martínez Guzmán, there is a difference between the contextual relevance (vigencia) and the overall validity (validez) of reason (Martínez Guzmán: 2001 p.24). Still, for Martínez Guzmán, through practical reason, one is able to ask and hear from another if one's acts are conducive to peaceful relations and whether these could lead to moral instances and institutions.

On the matter of reason as an eminent peace-making approach, Martínez Guzmán became aware of its locality and geographical context (Europe). Therefore, the panorama that unfolds in Martínez Guzmán's philosophy is one of a conversation from his cultural perspective (his European one), and others, and an openness to change when called upon. This perspective thus calls for feminist, post-colonial, ecological perspectives to always be considered, heard and integrated critically (Martínez Guzmán: 2001 p.18-19). Thus, the role of peace education would become fundamental for regulating such conversations.

With this, peace education and its corresponding peace research became an agenda for Martínez Guzmán. He started studying and assessing those stances - both academic disciplines and practices concerned with peace. Among them, Martínez Guzmán counts the study of conflict and war - International Relations, development and humanitarian aid/human rights as well as feminism, the epistemologies of the south and communication (Martínez Guzmán: 2001 p.75-114). Through Martínez Guzmán, the object of this thesis the deeper reflection onto the role of International Studies for peace from a perspective of love - becomes possible. 
At the same time, Martínez Guzmán has continued with his effort to deepen his understanding of peace through philosophy and, more recently, started his own research about love. Martínez Guzmán recalls that, etymologically speaking, philosophy comes from Greek, standing for love of wisdom. Yet, the nature of the love that phileo stands for is a sort of passionate affection. In this sense, Martínez Guzmán understands philosophy as "ganas y aficción apasionada por saber sobre la naturaleza y los otros seres humanos" (Martínez Guzmán: 2005p. 29). Thus, for Martínez Guzmán, wisdom, knowing is fostered by the admiration, marvel and curiosity of the world and those around us. Moreover, he recalls the notions of agapao, which stands for loving-kindness, care, compassion, diligence and also charity. However, he warns against the cynicism attached to the notion of charity as understood today, and proposes retaining the understanding of charity as caritas, as a commitment to transformation in the face of conflict and injustice (imbalance). In reference to the normalized approach to conflict as a legal matter, For Martínez Guzmán, those agapean characteristics of love render reconciliation and conflict transformation nonviolent in nature, thus subverting the tendencies of revenge and punishment that justice can acquire (Martínez Guzmán: 2005 p. 29-32).

At the same time, Martínez Guzmán recalls that the love of wisdom in philosophy has never required knowing and reason to be divorced from feelings and affections. Therefore, the suppressed part of our bodies where feelings take place, whatever is not mind or reason, also has ways of knowing. Human bodies can ask questions, and through their experiences also become sources of knowing others and the world. With this, Martínez Guzmán redeems the erotic nature of love, retrieving tenderness and sensibilities of the bodies as aspects that need to be considered in conflict transformation.

Martínez Guzmán, on the other hand, is aware that not always human response to others and one's environment is of a positive nature. Often we are dominated by fear and 
rejection, for instance. Fear and rejection, for him, compose a big source of conflicts and violence, leading to politics of domination and control such as patriarchy, nationalism or securitization (Martínez Guzmán: 2005, p.32-36). Yet, a response to disarm this stream of thought and action is to acknowledge that human life is indeed frail, but this feeling of frailty does not need to call for division and insulation, instead it can call for the realization that we need one another, and that life can be more fulfilling in this way. It is this feeling of frailty that opens the door for love as the expression and regulation of human relations, of ethics and politics. For Martínez Guzmán, those feelings that become gateways for love deserve a certain tuning, a grammar that captures how they can become tools in conflict transformation (Martínez Guzmán: 2005, p. 139-140).

Through his research, Martínez Guzmán has become a trailblazer for exploring the links between love, peace and international studies.

\section{8- Irene Comins and Care Philosophy:}

Doctor Irene Comins is one of the first students of Vicent Martínez Guzmán, and has followed his steps not only in the administration of the Peace Studies Masters and $\mathrm{PhD}$ Degrees at UJI, but also in doing a "positive peace" research, as investigator for the UNESCO Chair of Philosophy for Peace at the same university. Comins has focused most of her research on care philosophy and ethics of care for peace and peace education, which culminated in her book Filosofia del Cuidar published in 2009.

As Comins devises on Filosofia del Cuidar (2009), the idea of care ethics came to life through Carol Gilligan's 1982 book titled In A Different Voice. In it, Gilligan challenged Lawrence Kohlberg, her own teacher at Harvard, in his assumptions that women achieved a lower level of "moral development" when compared to men in a scale derived from Jean Piaget's cognitive development theory. Gilligan had realized that many social 
values were taken as facts (Gilligan: 1993), to the dismay of women, and that Kohlberg's research only evidenced that. Kohlberg's assumption was that to each corresponding cognitive level, there was a corresponding capacity in evaluating what was morally good from bad in society. Kohlberg devised three levels of moral development: a preconventional level in which people acted morally motivated by fear of punishment and or blind obedience, a conventional level in which people could understand the importance of law and order for conviviality among their peers, and a third, postconventional level, in which people would observe universal ethical principles. Not only did Gilligan question Kohlberg's sole use of boys and erasure of girls in his study, she also noted that subjects experienced regression to previous levels during their teenagerhood. (Comins: 2009, p.3134)

Gilligan also noted that women's morality did not function through decisionmaking processes between good or bad options. In Gilligan's perspective, women analysed decision-making also considering the possibility of accommodating difference and different choices. These would lead to innovative ways for addressing conflict and a larger capacity for creating exceptions to general rules (Gilligan: 1995, p.33 apud Comins: 2009, p.31-34), thus caring for a larger number of people and matters involved in their decisionmaking. Gilligan's research showed how Kohlberg's bias overlooked fundamental aspects of morality - of caring for others in an inclusive way - because women were neither regarded as objects or subjects of a study on morals. It is particularly this act of caring that Gilligan retrieves as a form of relating; not through an essentialization of biological women as natural caretakers, but through historical evidence of social constructions (following Beauvoir) that, traditionally placed women as the ones taking care of children and others, especially through motherhood (Comins: 2009, p.39-43). At the same time, Carol Stack argues that there is a 'vocabulary convergence' between men and women on topics such as 
rights, morality and wellbeing under economic deprivation (Stack:1993 p.109 apud Comins: 2009, p. 48) that focuses more on care (and the importance of its immediacy) rather than on social justice which leads to a longer struggle. As a matter of fact, Irene Comins stresses that an ethics of care functions as a complement to justice, not in opposition to it. (Comins: 2009, p.52)

In a world in which we hold the potential to - and do cause - suffering, engaging with conflict transformation and searching for justice produces frustration, sadness, anger, emotional bruises and pain. Although these are experiences every individual undergoes, they are not necessarily meaningless or easy to undergo, and at times they may seem like too much for one to bear. The point I take from care ethics is to attend to that, so we can carry on living "sustainably" in the long run, in the pursuit of transforming human suffering. Because it seeks to provide care mostly to our pains and struggles, it addresses our feelings complementary to our search for justice, reestablishing harmonious balances at the microlevel. Oftentimes feelings are overlooked due to a long history of opposing them to one's use of reason (one's cognition) - as is the case in Western modernity and post-modernity, in order to address the issues of the world - the issues all of us experiment collectively. A basic component of justice and ethics is understanding what others feel when they experience something. In other words, it is about empathy.

An ethics of care, focusing on sustaining life, is less prone to dramatic arches of burn out for great individual achievements, knowing that at times one's sacrifice is too many, and that such a stance focuses too much on grand, emotional, and heroic narratives. It is not a requirement, though, for feelings and emotions to be explored in such ways, running the risk of turning into sentimentality.

Such sentimentality, in fact, might also be a pathological outcome of ill-conceived care that takes shape in the self-centeredness of the caretaker and his/her desired outcomes, 
in which any relation towards alterity vanishes and gives way to projections and rendering others invisible. Comins acknowledges that even well-meaning individuals run these risks when care starts suffocating the objects of such care, suppressing their own expression and any form of dialogue (Comins: 2009, p.52 and 76).

In its healthy spectrum, according to Comins (2009, p.76-82), an ethics of care has a wide range of contributions to peaceful conflict transformation and, as such, has a relevant place in peace research. Some of these contributions are: the attention to multiplicity, escaping Manicheist tendencies that oversimplify complex phenomena that involves a multitude of factors and beings; likewise, rejecting polarizing winners versus losers dilemmas; stronger focus on attending to needs rather than punishing non-observance of needs. Lastly, according to Comins, an ethics of care shares many attributes of non-violence theory, particularly through the very strength of love in its manifestation as tenderness for others; appreciation, recognition and support of life in all its forms (Comins: 2009, p.8286). It is therefore at this injunction that love becomes more prominently present in Comins'

research, as she notes that it has been ostracized by most scientific disciplines - including the human and social sciences, and deserves a rightful place as a human value (Comins: 2009, p.82) that informs all our activities. In my view, this also includes the pursuit of justice as the ramification of an ethics of care.

\section{9- John Paul Lederach:}

After his extensive experience as a conflict worker and mediator in several regions and countries, John Paul Lederach has become a hallmark in peace studies with the proposed shift from the nomenclature of conflict resolution to conflict transformation. Drawing from his own experience in the 1980s in Central America, Lederach began to 
understand that the term conflict resolution often meant, for the conflictive parties, an intent to render invisible and mute their legitimate concerns and issues (Lederach: 2003). Therefore, in an effort to honor and respect the people he was working with, Lederach strived to find a term that heard and took in consideration people's issues and addressed them. He then proposed the term transformation, which seemed to tap into the fact that the conflicts people experienced were indeed normal and part of human life, while they also carried out opportunities for learning and change. For Lederach, Conflict transformation strives to see not only the immediate situation at stake (the episode), but also the underlying patterns and contexts in this situation, while providing a framework that addresses not only the content of conflict but also the context in which they are given, along with the structure of the relationships between conflictive parties (Lederach: 2003 p.10-13).

Conflict Transformation is to envision and respond

To the ebb and flow of social conflict

As life-giving opportunities

For creating constructive change processes

That reduce violence,

Increase justice

In direct interaction and social structures, and respond to real-life problems

In human relationships (Lederach: 2003 p.14).

At the core of Lederach's nomenclature shift from conflict resolution to conflict transformation lies a perspective of compassion for people's life, their own processes of unfolding and the hidden opportunities of change that catalyze the potential of loving. It is about finding the nurturing responses for human relationships that reduce violence. Moreover, conflict transformation bears in consideration the impossible dissociation between individuals, their peers and environment, which calls for a response that is respectful to the sustenance of all living parts of a system. 
With the perspective of conflict transformation in mind, particularly aware of how he could reduce the violence of dismissing people's own capabilities for peace, in Preparing for Peace (1996) (but also on his 1995 book entitled The Little Book of Conflict Transformation), Lederach explores a different way to approach the conflicts in which he was intervening. Understanding people's suspicion of what a foreigner could do to address their own conflict, Lederach realized how little he could actually do in order to change people's reality in a way that was not determined by his own interpretation of issues and facts at stake - or, in other words, from his own cultural perspective.

Lederach proposes a model in which the conflict worker developed an awareness of their own role and bias and how it could affect already delicate situations. This model was an effort to make conflict workers become catalysts for the people they worked with to uncover and discover their own potential for conflict transformation, in lieu of having conflict workers posing as conflict experts who diagnosed people's issues and prescribed them a solution. Lederach's central tenet was harnessing trust and commitment to realize that people who experience conflict can and do unfold approaches rooted in their own cultural context. This in turn would avoid direct imposition, nurture creativity and unleash people's own potential for peace. Lederach called this model elicitive, for it elicits untapped sources and skills of conflict transformation and peace.

However, Lederach mentions that he does not entirely rejects the prescriptive approach. He understands that the prescriptive approach is based on the fact that in certain situations there already exists a bank of knowledge that can be accessed and put to practice for conflict transformation. This perspective understands culture as technique. Lederach points out that the problem emerges when a prescriptive approach becomes an overarching model in which there is no room left for contextual adaptation, thus rendering it a narrow and often arrogant perspective (Lederach: 1996 p. 70). 
In practice, with the conflict transformation approach, what Lederach is doing is developing human capacities to see issues as opportunities for learning, tapping into compassion born by experience and putting oneself in the other's shoes by hearing and engaging with others and by thinking creatively in the face of complexity. Ultimately, in Lederach's concerns one finds the loving perspective proposed by Carl Rogers' humanistic psychology (of trust in human potential) brought to intercultural conflict scenarios. Moreover, Lederach's approach bears many similarities with the approach taken by Adam Curle's in the conflicts he strived to de-escalate through tapping into love, or the Mind of the Universe as he referred to it. But Lederach does so in a way that does not shy away from the complexity of human relations and conflicts, and tries to articulate responses that do not rely only on the political level but on the various facets of conflict such as the personal, relational, cultural and structural aspects that call for change.

Carrying on with the task of social change through the specifics of situations and contexts of each conflict (and a hint of past experience), in The Moral Imagination (2005), Lederach starts noting how personal aspects can allow one to uncap the creativity necessary to innovatively respond to the demands of conflict transformation. Lederach states, "When we attempt to eliminate the personal, we lose sight of ourselves, our deeper intuition, and the source of our understanding - who we are and what we are in the world" (Lederach: 2005 p.viii). Additionally, it is important to mention that those personal aspects do not eliminate others but are in connection with them.

For Lederach, the moral imagination is the process of transcending violence, including the complexity of one's subjectivity as well as others', while also aware of the landscape of violence around people. Thus, he considers that the moral imagination requires some capacities such as imagining people in a web of interconnectedness, sustaining respectful curiosity and openness towards difference. It is the obstinate pursuit 
of mastering the art of conflict transformation and the awareness that one can still fail, but may always rise again. Defining conflict transformation as an art allows Lederach to aproach Erich Fromm's perspective of the art of loving. While Fromm understood commitment and diligence as requirements for the art of loving that needed to be honed, Lederach uses the aspect of "moral" referring to the imperative, fundamental necessity of engaging with conflicts with creativity. "The fundamental belief in and pursuit of the creative act" (Lederach: 2005 p.5) is an element of both the arts of loving and conflict transformation.

Thus, for Lederach, the moral imagination is "the capacity to imagine something rooted in the challenges of the real world yet capable of giving birth to that which does not yet exist" (Lederach: 2005 p.ix). This not only shows the compassion for stimulating people finding their own way out of conflictive situations but also points to new forms in which they can thrive. This passage strongly resembles Freire's assertion of the untested aspect that lies beyond one's horizon, underscoring that transformation, like love, allows us to reshape and reinvent the world.

To imagine something so distant from reality - imagining peace "when blood and bones are crying out" - is not an easy task. In the face of "the unspeakable", and beyond objective aspects of conflict transformation (or, more often, resolution), there has to be something that reaches the depth of someone for healing to actually start. In his book entitled precisely When Blood and Bones Cry Out (2010), Lederach explores the ideas of space and movement towards people (encounter) necessary for people to channel and voice their experiences. This movement and space, however, as Lederach notes, are provided by a "tangible surrounding love that nurtures the space for individuals and collectives which still know full well that the animosity, enmity and violent patterns are still present" (p.227). 
It is unconditional love that can foster those opportunities for one to experience deep healing and reconciliation.

At the same time, Lederach emphasizes that indeed "[1]ove has not been commonly a topic of much discussion in the literature on healing and reconciliation" (p.230), suggesting that peace research might not have developed deep into love due to the peace researcher's effort to present their work as a rigorous science. In this chapter, I highlight the very opposite, as there has been significant and ongoing peace research on love, and if not openly, it at least remains as topics that they invariably touch upon or drives them, just like Lederach did.

\section{0- Wolfgang Dietrich:}

In his own peace research, Wolfgang Dietrich has become aware that his colleagues and students, from diverse cultural backgrounds, seem to have different concepts and ideas around peace. He also realized that those concepts did not always match, having very different ontological and epistemological grounds. Therefore, Dietrich's work started from an effort to identify the many forms and experiences of peace in the world which were coded through different cultural perspectives. This led him to A Call for Many Peaces, a working paper written in 1997 with Wolfgang Sützel at the Burg Schlaining Peace Center in Austria, drawing from Ivan Illich's insight that, while a state of war assimilates culture (and thus concepts of peace), peace allowed culture (and their own concepts of peace) to blossom in unique cultural expressions.

The natural work to follow such a call would be then to devise a cartography of different cultural expressions of peace. Such an effort is primarly present in the monograph that Dietrich edited along with Josefina Echavarría, Gustavo Esteva, Daniela Ingruber and Norbert Koppensteiner in The Palgrave International Handbook of Peace Studies, first 
published in 2011. In The Palgrave International Handbook of Peace Studies, the team mentioned above invited authors to share the vernacular concepts of peace in their own cultural contexts, from several parts of the world, such as Africa, the Americas, South and East Asia, the Middle East and Europe. Despite the books breadth, there still remains a large number of expressions of peace to be further explored, expanding this work.

From this insight, another scholarly step taken by Dietrich was trying to find common threads in those apparently so different concepts of peace, which culminated in the 2012 book entitled Interpretations of Peace in History and Culture, the translation of an original work published in German in 2008. Of course, the most direct interpretation was of a modern nature. Modern interpretations of peace are rooted in Cartesian mentality and put forward by a scientificism that dominates Euro-modern ways of thinking (or rather, producing knowledge), and are found also in several peace research and peace studies programs. A modern expression of peace is one in which certainty allows for a determination of the appropriate human conduct that secures life. Thus modern peace is conceived as security.

But such modern interpretations of peace find their roots in a moral one: moral interpretations of peace rely on the word and commandment of God as sources of knowing what true peace is. Therefore, over moral interpretations of peaces, peace is that state of leading life according to a canon pre-given by God, but that is interpreted by an elite of initiated few, and according to it we shall be judged: those who follow it shall reach heaven as the ultimate prize, those who do not shall see punishment for not obeying the word of God. Thus, the main theme of moral interpretations of peace is justice. At the same time, a reaction to the modern interpretation of peaces can be found with the post-modern stance of rejection of a single way of conceiving peace. Post-modern interpretations of peaces use modern reason in order to pluralize and embody the idea of peace(s) and safeguard the 
diversity of different ways of interpreting the world. Hence, the main topic of peace in postmodern stances is truth. However, such post-modern rational rejection of any prominent form of understanding peace ultimately leads into nihilism and renders life paralyzed, mostly due to an impoverishment of ways to conceive life that do not ultimately rely on rationality.

But Dietrich started seeing certain interpretations of peace that did not fall neatly into those three categories he could devise. In contexts in which either moral or modern interpretations of peace (and thus the reactive postmodern stance) did not hold a strong hand, there seemed to be a certain mode of interpreting peace that integrated forms of spirituality, intuition or subjectivity. But, above all, those interpretations contained an idea of peace as harmonious relations between humans, nature and the cosmos. Those interpretations of peace were thus an expression of interconnectedness between all things. The microcosm and macrocosm should correspond, sublating the dualities of inside/outside, internal/external. The experience of peace in this interpretation is to begin from the innermost part of the self and spread harmoniously into the universe. Dietrich therefore called these interpretations energetic interpretations of peace, which can be found and expressed in all continents in all times in vernacular and personal/subjective experiences.

Of course, taking the post-modern insight of doubt, each of the above mentioned interpretations of peace have their own pitfalls and limitations, and this invited Dietrich to explore the integration and differentiation of those perceived interpretations in order to provide a richer framework of peaces, responding to each context. Plus, in his own cultural context, the suffocating post-modern environment invited an exploration of Eastern traditions such as Taoism and Hinduism and their deriving spirituality, psychology and philosophy. Therefore, having perpassed (post-)modern rationality to explore those 
energetic traditions but not entirely rejecting or abandoning rationality, Dietrich called a fifth interpretation as transrational interpretations of peace, as it in sum combined (post)modern rationality with energetic concepts of peace. Transrational interpretations of peace seek out the harmonic balancing on the four recurring topics of moral, modern, postmodern and energetic peaces, that is: justice, security, truth and harmony.

It is from this point that an exploration of love becomes more prominent in Dietrich's work. In moral interpretations of peace, love is submission and obedience. In modern interpretations of peace, love is a laughable if not cynical aspect of human existence to be disregarded. In post-modern interpretations, love is a category to be taken somewhat into consideration. But, in energetic interpretations of peace, love is an expression of cosmic breath manifested into human behavior. Therefore, the concept of love in transrationality would be the expression of this cosmic energy into human life and needed to attend to the issues raised by a need of transformation in matters of (in)justice, (in)security or doubt. Dietrich notes that the concept of love in transrational interpretations of peaces can be conceived partially through Ken Wilber's philosophy that combines Yogic traditions with Western Philosophy, although Dietrich does not share Wilber's evolutionism. For Wilber, transcendence would take place in the ascendant movement of cosmic breath towards god which manifested into love, or Eros. This love as celebration of divinity in turn would have a downwards direction also in the form of compassion or Agape. Also, in Dietrich's Elicitive Conflict Mapping (2018), an approach that combines John Paul Lederach's concept of elicitive conflict transformation (mentioned in this chapter) and the mind mapping methods proposed by Tony and Barry Buzan (Buzan: 2010), there are further explorations on love.

Elicitive conflict mapping is not the same as conventional conflict mapping. It is a tool for finding and keeping orientation in applied conflict work. It helps the conflict worker in the analysis of the dysfunctional relations, finding balance in the confusing web of themes, 
levels and layers of the conflict pyramid (ECM Online: 2015)

In Elicitive Conflict Mapping (ECM), the most important parts refer to clarifying the conflict's episode, which is different from a conflict epicenter, it also allows for the conflict worker to visualize all the parties directly or indirectly involved in the conflict and, finally, it allows for understanding the multiple layers, levels and themes that operate at the conflict. The conflict themes, as explored in the interpretations of peace, are those regarding harmony, truth, justice and security. The levels are all those top, middle and grassroots level people that pose an impact in the conflict scenario, but, despite its apparent structuralist definition, all actors interact across their social strata.

The layers of the conflict or the parties in the conflict refer to the seven chakras yogic philosophy that allows for understanding where an irritation might be irradiating from, and in this perspective every intra-personal layer has a corresponding inter-personal aspect. These layers are: the Episode; Sexual-Family Layers, corresponding to svadhishthana chakra; SocioEmotional-Communal Layers, corresponding to manipura chakra; Mental-Societal Layers, corresponding to anahata chakra; Spiritual-Policitary Layers, corresponding to vishuddha chakra; Global Layer, corresponding to Ajna chakra; finally, Epicenter or sahasrara chakra.

For the matter of love, the mental-societal layer or anahata is of fundamental importance. In the chakra philosophy, anahata stands for unconditional love and compassion, and is located in the heart. The mental-societal layer, however, considers that anahata comprehends also the mind along with the heart, despite the apparent contradiction:

The intrapersonal, mental aspect provides the persona with the potential for reason and consciousness. The intrapersonal and mental as well as the interpersonal and societal layers comprise all the previously mentioned ones, and enable the persona and societies, precisely through this potential, to become conscious of the previously mentioned layers. The heartbeat causes and symbolizes the life of the persona. And life transforms transrational qualities like love, compassion, and devotion, by bringing them into the episode in ways that can be grasped by the senses, and by rendering them conscious experiences. Thus, it is 
mental awareness that balances the sexual, family, and social energies in an episode (UNESCO Chair for Peace Studies: 2014).

Accordingly, in the microcosm, an open heart and self-awareness are fundamental aspects to work on if loving and compassionate energy of anahata is to flow in balance and affect my own relations. At the same time, due to its correspondence on the macrocosm, it is important to be aware of the larger society I am a part of, beyond my immediate community and kin. At this point, the research on love that can be fostered through Dietrich's (and the UNESCO Chair for Peace Studies in Innsbruck's) work becomes a major tool to analyze that which has been a fountain of conflicts on the micro and the macro-level together: on the micro level the dissociation of heart and mind, on the macro level imagined societies that exclude and deny alterity and how those are interconnected aspects. Mental clarity therefore is an important form of awareness that goes beyond rationality, for it includes (inter)subjectivity in one's reasonings, and responds to it according to context, parties and self.

Rationality is not only a possible means for conflict resolution, but more often than not it is the capacity for rational abstraction that constitutes the cause and trigger of conflicts. Whether it is ideological or religious, material or idealist, competitive or cooperative ideas about the correct form of organization for people and societies, it seems that at the beginning there is always a rational idea that is created and, in its career with other competing ideas, can turn into an extreme functional and justifiable use of violence. From an elicitive perspective, it is clear that such conflict cannot be transformed with the same poison that created it. A conflict, whose episode is primarily an idea of the parties, tends to become an even more destructive clash of arguments when third parties feed even more reason into it. Here, a reorientation towards other layers is highly recommendable. As much as reason serves the conflict worker to recognize and to balance possible blockages in the equilibrium in all layers, it can equally be obstructive if it turns into a self-referential storyteller that reduces all dynamic aspects of a conflict to its own mono-dimension. Elicitive conflict transformation is aware of this danger and tries to keep it in check through supervision and repeated reality checks. Contrary to prescriptive models that follow the abstract resolution model of reason, elicitive methods use reason for working in all layers on the different impulses that they receive from the parties when acting in resonance. Such 
impulses are filtered by reason and are fed back into the system, yet without a pre-conceived resolution model. For conflict workers to be able to feed this back without creating more distortions, they need mental clarity, whose precondition is a dynamic equilibrium for the worker him/herself at these very same mental and societal layers. (UNESCO Chair for Peace Studies: 2014).

Herewith, Dietrich's proposal of Elicitive conflict transformation becomes yet another perspective to include and explore in depth love as a category and aspect that has to be considered in peace research and that could enrich and integrate different areas of social research and humanities.

\section{1- Pierre Weil:}

Pierre Weil was born in Strasbourg, France in 1924, in a multi-cultural environment, as his mother was a French catholic and his father Jewish-German. In his childhood, Weil created theatrical plays which he later considered his first incursion into psychodrama. Growing up in a region politically disputed by France and Germany, Weil lived through the German invasion of France, and as a boy-scout helped the Jews escape from the Nazi forces. During World War II, he acted as a partisan against the Nazi forces, choosing to act as a nurse rather than engaging in direct violence and carrying guns. Later on, influenced by the constructivism of Jean Piaget (of whom he was a student), Weil dedicated his life to the matter of peace through conviviality and the role one had in developing his/her relation with the world. After he became a doctor in psychology at the University of Paris VII and after he received additional training in the psychotherapy of Jacob Levy-Moreno (with whom he became friends), Weil pursued research on, amongst other topics, different aspects of personality and on cultural and educational factors in intelligence (Kladi: 2009).

In 1948, invited by Leon Walther, a specialist in Industrial Psychology, Weil went to Rio de Janeiro, Brazil to train the staff of the National Service of Professional Learning 
(SENAC), particularly the vocational orientation. He eventually settled in Rio, running the education division of that institution. There, Weil continued research on psycho-pedagogy at the Pestalozzi Institute, taught Philosophy at the Federal University of Rio and helped draft the law that regulated the profession of psychology in Brazil. Later on, in Belo Horizonte, the capital of Minas Gerais, he taught in the first psychology degree program of the country, at Federal University of Minas Gerais, where he continued his research on psychodrama. During the sixties, after a deep experience in a directed psychodrama in Paris, Weil opened up to transpersonal psychology, which brought him to present on the cosmodrama at the Esalen Institute in California, which became his main interest in terms of peace (Kladi: 2009).

His research on transpersonal psychology and the personal experience of cancer led him to approach Yoga through Swami Chidananda, Muktananda and Tibet lamas such as Kanjur Rimpoché and Pemala Rimpoché, taking him to the Himalayas for a retreat of about three years. Soon after his return to Brazil, he was invited to coordinate the City of Peace Foundation in Brasília and, supported by Monique Thoenig, director of the Holistic University of Paris; Weil created the International Holistic University of Brasília known as UNIPAZ, in Portuguese (Weil: n.d.).

At UNIPAZ, Weil had the opportunity to combine his research on Western psychology with the teachings he received at his Yoga retreat, which culminated in the book The Art of Living in Peace, first published in French in 1992. The Art of Living in Peace departs from the importance of a "paradigm shift" towards a new consciousness that allows Peace to manifest in a holistic manner. Thus, it was designed as an education program contaning provisions on cooperation, education, science, culture and communication throughout different cultures, starting with the educators themselves (Weil: 1994). 
For educators to be in tune with the times and to be able to respond to the demands of current events, we must provide them with the educational methods for transforming consciousness, starting with their own, so that they themselves can be examples of peace and harmony. Indeed, how can we change other people, if we do not start with ourselves? (Weil: 1994 p.14)

Weil's approach departed from addressing the perception of a state of fragmentation in several dimensions of life, caused mostly by a Newtonian-Cartesian paradigm. This fragmentation, presented as specialization, led to a myopia to what is essential in life.

This worldview has generated a crisis of fragmentation that has reached the point of endangering the survival of all life-forms on the planet. We have arbitrarily cut up the world into territories which nations consider their sole property. We have divided knowledge into science, philosophy, art and religion. Each of these fields has in turn been subdivided into countless others (...). We ourselves, as human beings, have been split into body, emotions, mind and intuition. It is exactly such divisions that underlie all the different interpretations of what peace is, as well as of what hinders or brings peace about. This world view is also, of course, one of the main reasons why peace was lost in the first place. (Weil: 1994 p.22)

Weil considered that a new peace consciousness could arise from the encounter of quantum physics with transpersonal psychology and the wisdom of great spiritual traditions, all contending that the systems of the universe would be all formed by the same energy despite the fact that the apparatus of the human mind divides it. He thus proposed a table of a non-fragmentary vision of energy that made explicit the forms of manifestation of energy and corresponding sciences: 
NON - FRAGMENTARY UISION OF THE ENERGY

MANIFESTATIONS AND THE ACCORDING FIELDS OF SCIENCE

SYNOPTIC TABLE

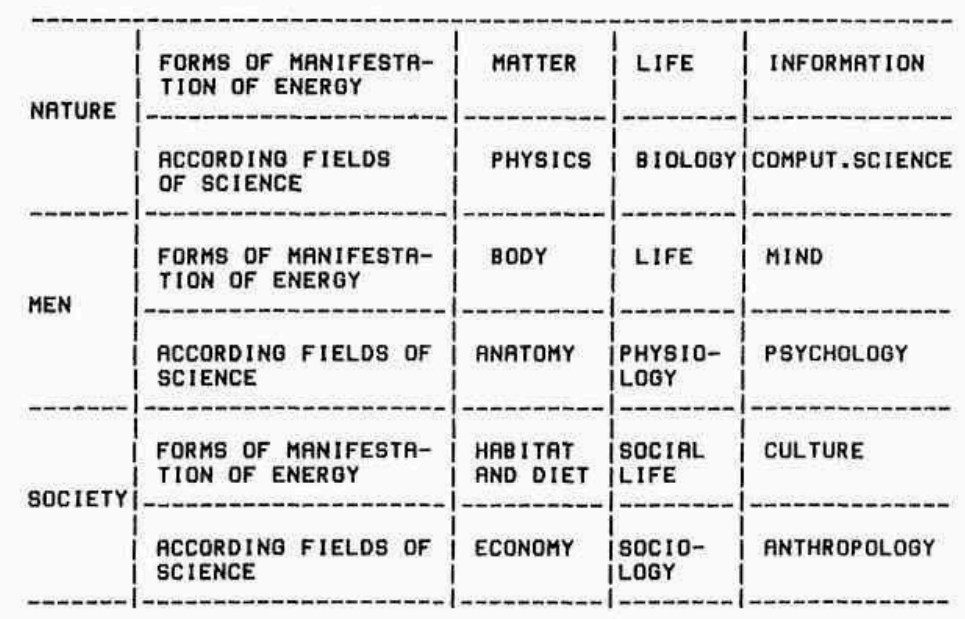

Figure 1: Non-Fragmentary Vision (Weil: 1994 p.20)

Moreover, the Newtonian-Cartesian paradigm, through the duality between object and subject, allowed for further fragmentation when it came to peace. It could either be external or internal to oneself, but the internal peace was not a realm deemed worthy of addressing. Thus, one can see the focus on the peace of the object. It would be manifest mostly through the lenses of the social sciences, having a cultural, judicial, political, social and socio-economic dimension.

But the holistic approach that Weil proposed took to heart the UNESCO's preamble that peace must be built in the minds of men [sic] and, thus also consider inner peace, the peace of the subject. Even if humankind got rid of all weapons, we would still use words and our own hands to fight. It has to include peace within. In this line, Weil emphasizes two perspectives that mostly correspond to the approaches taken by the West and East when it comes to inner peace. For Weil, in the West inner peace is understood as the absence or dissolution of inner psychic conflicts. From a psychotherapeutic perspective, this would 
mean the elimination of conflicts between ego and superego, heart and mind, intuition of the heart lead to peace. Meanwhile, Weil considers that, in the East, peace manifests from the detachment from any concept, being or object, and has a spiritual dimension (Weil: 1994 p.27).

Still, Weil would say:

We cannot have true peace on a personal level if we know that poverty and violence hold sway on the social level or that the natural world threatens to destroy us because we are destroying it. The holistic vision or consciousness implies a progressive broadening of consciousness. It begins with a personal awareness and dissolution of egocentric aspects and a progression towards a social consciousness, although still an anthropocentric one in other words seen from an exclusively human viewpoint. As and when society realizes the extent of its dependence on the planet and all its life forms, social consciousness will evolve into planetary consciousness. Even then this will still be to some extent geocentric, with its perspective somewhat limited to our planet, regarding it as the center of the universe. The holistic vision, therefore, is a cosmic consciousness of a transpersonal, transsocial and transplanetary nature, which integrates these three aspects into a broader perspective. (Weil: 1994: p.28)

Therefore, the holistic approach to peace of Weil aimed at addressing not only the peace of the object but also the peace of the subject, either from a Western or Eastern tradition. Preferably, it combined both as a strategy to let peace emanate from within and find correspondence in the social and collective dimension in an ecological fashion. The holistic approach that Weil proposed implied a non-fragmentary theory in which energy manifested in the form of matter, life and information and took into account the interconnection and constant interaction between human beings, society and the natural world, or, in other words, personal, social and planetary ecology (Weil: 1994 p.28).

It is through Weil's rendering of inner-peace in connection with external peace, thus, that love emanates from his work. Love becomes the driving force for selfactualization in sync with work and commitment with what I perceive outside my bodily 
layer, transposing barriers created by the human mind but reified even more by the Newtonian-Cartesian paradigm, thus perceiving the interconnectivity of all human beings and calling for resonance of peace and non-violence.

For Weil, the corresponding practice of love for peace involved drawing and highlighting perspectives that addressed the person as a whole to help her maintain and (re)establish harmony between the senses, feelings, mind and intuition, thus rethinking their relationship to the world around (and within) their. It concerns physical health but also emotional and mental balance, and the awakening and sustenance of human values (Weil: 1994 p.36). "By radiating qualities such as affection, gentleness, patience, openness to the needs of others, the ability to put themselves in somebody else's shoes, and so on, would render all other forms of instruction unnecessary" (Weil:1994: p.43). With this, Weil sets the tone for approaching international studies from a gaze of love.

\section{2- Final considerations on love in peace studies:}

Throughout chapter two, I concentrated precisely on exploring how love has been dealt with in what has been considered peace research. While the association of peace with love remains an elusive reference to the hippie movement from the nineteen sixties, a more detailed look at this association deserved some attention. Despite the fact that not many peace scholars have explicitly or directly discussed love, in all the peace researchers I have explored in this chapter there was at least one reference with regards to the role love has for peace.

Galtung had a timid approach to love when conceiving peace research. When Galtung refers to peace research as "good social theory", I assume that good social theory is one that fosters aspects such as empathy, care, concern, commitment, compassion - which are all aspects of love detailed in chapter one. Kenneth Boulding stays true to Galtung's shy 
understanding of love. He is concerned with fostering an economic system that responds to wars and violence through the human potential of love, hence feeding into a systemic perspective of peace. Meanwhile, Elise Boulding retrieves how love has been overlooked through her commitment to bringing to light the hidden stories of peaceful and loving human relations, counter-balancing the deterministic narrative that violence is human essence.

And if there was any doubt on the relevance of exploring love in peace studies, Adam Curle categorically turns that into a necessity. He thus explores how love, as a channeling of the compassionate mind of the universe, has been a lasting response to the pain, suffering and violence of what he calls "the black cloud". Very close to Curle, Francisco Muñoz, lays out how the roles of altruism, solidarity, cooperation, as well as kindness, tenderness, friendliness, hospitality, all important characteristics of love, have been an effort to perfect the imperfect peaces we experience.

In turn, Vicent Martínez Guzmán explores the meanings of love in the Western philosophical tradition, particularly through the dynamics between Eros, Agape and Philia and their potential to regulate human life and conflicts in a non-violent way. His effort to shed light on how those concepts can be present in our life to make peace happen could have been further attested to by his research on love, which he sadly could not continue due to his passing during the summer of 2018.

Through his reflection on his experience as a conflict worker and through the concepts of elicitive conflict transformation and the moral imagination, John Paul Lederach has brought to the forefront of peace and conflict research love as that subtle and all too often overlooked subjective element that nurtures healing and reconciliation and sets forth new and creative ways to respond to the challenges of human life. Tapping into this perspective, Wolfgang Dietrich started exploring love in an energetic fashion mainly through the 
exploration of the mental-societal layer of his elicitive conflict mapping and its correspondence to the anahata chakra in yogic philosophy. Pierre Weil, quite close to Dietrich, eludes to the importance of unfolding one's consciousness in order to be of service to conflict transformation and the experience of peace. 


\section{Conclusions to Part I - Love and Love in Peace Studies:}

The first chapter of this thesis started with a brief elaboration on the history of love within a Western cultural context (in ancient Greece, in Christianity, and in modernity) and its relevance for peace and human relations. With a careful distancing of contemporary and commonsensical assumptions of the meaning of love, I differentiate it from feelings and emotions and discuss its association with the heart, the anahata chakra, and how it also entails one's mind. From that point onwards, through Thich Nhat Hanh, I discuss Buddhism's main elements of love (loving-kindness, empathic joy, compassion and equanimity). With Erich Fromm, I establish how to pursue it as a form of art, and with Abraham Maslow, I discuss the human conditions for realizing love. Afterwards, I approach the practice of loving with Carl Rogers' radical acceptance and validation in counselling and have discussed its proximity to Martin Buber's philosophy of dialogue and openness, and also Levinas' encounter with the face of the other. Next, I discussed how politics may be infused with love with the examples set by Paulo Freire, bell hooks, and Gloria Anzaldúa, each dealing with human suffering and oppression. Deepening the reflection on the implications of oneself in this act of relating with others, lastly I discuss the gentle attitude that it requires via Vattimo's "weak" thought and one's way of communicating love with Marshall Rosenberg's Non-Violent Communication.

As a counterpart to the elaboration on the meaning, relevance, and practice of love, in chapter two, I discuss how love has presented itself in self-declared and/or hallmarks of peace studies, specifically commenting on Johan Galtung's departure from MarxistStructuralists concerns to a Buddhist turn. I explore Kenneth Boulding's concern with how to bring about peace in a systemic fashion, infusing it with love or extracting its love aspects. With Elise Boulding and Paco Muñoz, I discuss how traditional historiography has 
often neglected the will to and the acts of love in human history. Supporting their claims and evidences, Martínez Guzmán's philosophy reinforces the peaceful political relations committed to the transformation of society. This is the point in which Lederach becomes an important reference in peace studies. He puts into practice a commitment to/with humankind through his life as a Quaker missionary, acting as a mediator in contexts of protracted conflict. Lederach was an important inspiration for Wolfgang Dietrich. In his concept of transrational and energetic peaces, Dietrich combines humanistic psychology and cultural-anthropological insights, highlighting how personal drives and cultural elements can lead to peace, and love may be read as both personal drive and cultural element. In many ways, Pierre Weil may be considered Dietrich's predecessor for exploring a non-fragmentary and energetic approach towards humans and the implications for rethinking human relations. Last but not least, Adam Curle is not only the trailblazer for peace studies and conflict transformation but also the scholar who has dedicated the most work to the idea of love, derived from his social commitment and his inspiration from Buddhism, condensing all the aspects of love which I have discussed in chapter one.

At this injunction, there is no question about the role love plays within peace studies. In different ways, all the peace studies scholars represented here have been driven by a deep commitment with the transformation of human suffering within the reaches of their contexts. They responded to and were inspired by many ideas and many perspectives that dealt with matters of peaceful human relations. However, for the sake of peace studies and peace research, it is only fair to assert that it is time for a thorough review of the international studies literature that has influenced the establishment of peace studies programs all over the world. How some ideas and scholarly perspectives within international studies are changed if approached from an attitude of love, a human aspect many peace scholars have touched upon at least laterally in their research? What arguments 
and new interpretations are made possible if researchers implicates themselves in relating with the ideas contained in a text as well as with the author behind it? This is the topic covered in the second part of this thesis. 


\title{
Part II: Love and The Heirloom of International Studies for Peace Studies
}

\begin{abstract}
...while many a modern sociologist and psychologist viewed the phenomena of hatred, crime, war, and mental disorders as legitimate objects for scientific study, they quite illogically stigmatised as theological preaching or non-scientific speculation any investigation of the phenomena of love, friendship, heroic deeds, and creative genius. this patently unscientific position of many of my colleagues is merely a manifestation of the prevalent concentration on the negative, pathological, and subhuman phenomena typical of the disintegration phase of our sensate culture (Pitirin Sorokin: 1954, p. xxvi)
\end{abstract}

\section{Introduction to Part II- The Heirloom of International Studies for Peace Studies:}

After proposing a working definition of love and exploring how it has been discussed and has operated within peace studies throughout part I, in the second part of this thesis, I propose a reflection on international studies from a peace perspective in which love is brought to account as a fundamental aspect of the research endeavor. But, beforehand, it bears exploring the question of what exactly is international studies? There is no precise definition of international studies in which a clear-cut area of thought and its respective methodologies form a unified and coherent discipline. Rather, international studies has been considered an interdisciplinary approach to "current global affairs".

Although contemporary historiographical accounts point to a pluralization of world histories and perspectives - which ultimately leads to a multitude of standpoints on what effectively comprises global affairs, the term "current global affairs," as discussed in Thinking from the underside of history : Enrique Dussel's philosophy of liberation (2000), 
usually refers to the perspective of a globalization process that has highlighted the integration of human activities under one complex international system of states and institutions that regulate human life on a global scale. It is fair to say that this dominant narrative over the globalization process and the current state of the world has been strongly marked by the European cultural expansion over the course of the last 500 years and assumed the shape of a modern discourse, understood and also labeled as "Western" Modernity.

Under this Modern, Eurocentric or Western perspective, economic, political, and cultural issues all inter-relate and a comprehensive understanding of global phenomena cannot be reached by focusing only on either economics, politics or culture. For instance, wars in one region cannot be explained without political and economic measures taken on the other side of the globe and across time. Likewise, national borders seem to have become more of a problem in terms of human settling and migration rather than a means to facilitate human movement in the pursuit of better lives. At the border, politically persecuted people, refugees due to economic reasons or people from different cultures all experience trouble. Thus, a comprehensive analysis of the current world in which these troubles take place requires a combination of politics, economics and culture.

At first sight, in international studies, the blind spots caused by the fragmentation of human knowledge into specialized areas of knowledge seem to have made way for a more encompassing approach, as international studies has been considered an area of thought in which a combination of areas such as political science, history, geography, economics, anthropology aim at providing a richer interpretation of those complex world issues at stake (Anderson et al: 2016) within concrete contexts. Coming to terms with my own education on international relations as responding to its geopolitical context in Latin America, I can see thus that an international studies curriculum has mostly revolved around 
international political theory, economic development and international human rights law. All issues deeply embedded in Latin-American history through a Eurocentric and modern account: its borders and relations with colonial powers through International Relations, its economic issues with poverty and development, and the issues related to inclusion and respect through as rights. I can see that, in a way, these three disciplines provide a sense of the world that "rhymes", as international political theory offers an interpretation of how the international system socially functions, international (human rights) law aims at regulating and codifying behavior patterns and development aims at supporting its sustainability.

In a way, to this tripartite separation of knowledges, as mentioned in chapter 2 of this work, Pierre Weil would refer to energy in the form of life (relating - international relations), information (codified behavior communicated into human-rights/law) and matter (livelihood/economics, development) (Weil: 1994 p.20). Following this framework and for the purposes of this work, international studies comprises the disciplines of international relations, human rights and development. ${ }^{11}$

Although my perspective of IS is composed of international relations, human rights and development, it is important to say that this assertion is not final and, depending on what is relevant to certain locations, the composition of disciplines within international studies do vary. Likewise, this thesis provides a case that focusing only on political, economic and cultural matters does not suffice in understanding the world. International Studies shall remain limited and myopic as far as the aspect of human subjectivity is not included as a category of analysis and, psychology, for instance, is not included.

If one searches for a definition of international studies through the International Studies Association (ISA), one notes that it "was founded in 1959 to promote research and

${ }^{11}$ International relations and international studies are terms used often as synonyms. However, international relations is a subpart of political Science, which is usually considered within international studies, along with the other disciplines mentioned in this thesis. 
education in international affairs" (International Studies Association: 2019), but that no definition is given to international studies, as if a self-evident topic. Only through reading ISA's history can an author grasp the dominant understanding of international studies for ISA: ISA came out of a dissatisfaction with the American Political Science Association, which the founding members considered focused too much on USA domestic politics. It is out of this that one can assert that international studies dominant focus is on politics. And politics here is to be understood following political science - the objective study of governance, policy, political behavior in a Cartesian tradition - objectively and as far removed from subjectivity, human psyche and cultures conducive to peace - if compared to Adam Curle's grasping of peace studies as mentioned on chapter 2.

But, despite ISA's dominant focus on politics, when Kenneth Boulding was elected the president of the Association (the first non-political-scientist to preside over the association), his approach to international affairs involved a systemic one - interweaving the international domain with common human problems such as rights, boundaries, the environment; he also opened the association to perspectives outside of political science, widening the intellectual diversity of the association (International Studies Association: 2019).

Currently, the International Studies Association holds 28 topical sections, yet none is dedicated to, for instance, understanding international studies through psychology, as an area that explores concepts of the role of (inter)subjectivity in human life. Thus, following the steps of Kenneth Boulding, as the president of ISA and as a founding figure of peace studies, and filling a gap in the literature of international studies, in this part I situate my effort of exploring love, as not only a subjective but also an inter-subjective mode of relating, and what it has to say about international studies. This is an endeavor also supported by Lederach, as he asserts that 
Love has not commonly been a topic of much discussion (...). This may be due in large part to the burden experienced by peace studies researchers and authors: that our chosen field represents a 'soft' science struggling for legitimacy among existing disciplines. To directly and openly discuss love enters the slippery slope of the intangibles that lie outside the scientific endeavor. We beg to differ for a number of reasons (Lederach, 2010: 231).

Lastly, the second part of this thesis is also an effort of making sense of a personal disagreement with the way international studies has been dealt with in the institutions I have had contact with, what I take from it and how much of it has corresponded to the larger limitation of international studies as a "hard science", which excludes diverse perspectives once they are categorized as "unscientific" or "unmodern" and are erased, ignored, or flattened out of the dominant international narrative. 


\section{Chapter 3- Love in International Relations:}

...it has not been my experience that mainstream security studies/international relations (IR), (...) can be used as they are for peace studies, in the sense that all that would be needed is simply to bring them together and then start an interdisciplinary dialogue. To the contrary: they have to be rethought from the beginning (Galtung 1996, p.vii)

\section{1- Preliminary considerations on International Relations:}

Bearing that international studies (IS) is an area of thought that is by definition multidisciplinary (see introduction to part II), what is exactly International Relations (upper case: the discipline) and what is its difference to International Studies then? To clarify: International Relations is a discipline akin to political science that seeks to analyze the international phenomena around diplomatic strategies of states on the matters of war, conflict, peace (negative peace) and cooperation. The confusion between IR and IS seems to stem from the enlargement of IR to analyze other ideas and phenomena, such as Human Rights and Development, which the study of interstate violence did not originally encompass, but which came to bear significant influence on the discipline. Henceforth, the name International Studies was brought up as a more encompassing umbrella discipline.

However, the dutiful observation of names is a conceptual care that is not really observed in practice, and much confusion remains when one talks about "international" matters. As an example, Chris Brown (2005) notes that IR's topics have enlarged so much to the point of making it difficult to realize what IR is about, whether diplomatic-strategic relations of states, cross-border transactions and/or globalization, all complex topics in themselves, not to mention the fact that it is impossible to retain pure disciplines. Still, 
Brown further adds that despite the resemblances, these conceptions of what a discipline is made of do bear differences, and the definition adopted for international relations ends up posing significant consequences to either the disciplines of IR and IS: "how we understand and interpret the world is partly dependent on how we define the world we are trying to understand and interpret" (Brown: 2005 p.1). This critique remains especially relevant if we consider how the epistemology of IS is taken into peace studies without much thought.

Addressing the question of how we understand and interpret the world and organize ourselves around it, Robert Jackson (Jackson \& Sørensen: 2010) examined how certain pretheoretical steps that are often unacknowledged play a fundamental role in theory-making: defining the ontological, epistemological and methodological aspects of one's research bares explicit the assumptions and conventions made in any theoretical viewpoint (the approach taken in this thesis as laid out in the introduction). Thus, to be clear, IR is understood as the analysis of inter-state war conflict and violence, with implicit ontological assumptions that frame/lock the reader's conceptions of reality of a violent world populated by States, excluding the role of human agency and human potential in ending violence and transforming conflict.

Along with these assumptions of reality made in IR theory (theories) which pave the way into IS and into peace studies, there remains also issues regarding what constitutes legitimate ways of knowing, or its epistemology: should the phenomena of war be understood (only) from objective observation in a Cartesian fashion? Does not human psyche and experience play a role in eliciting violence and becoming violence-centered? Does not violence affect how we engage with the world? Answering both questions with a yes brings about the fact that experiential, biographical and subjective ways of knowing deserve further attention. The question becomes then: which would be the most adequate method for analyzing wars? Would falsification based on data analysis (history) either in 
quantitative or qualitative fashion be enough? Or would not human narratives on their personal struggle and connection with the topic of IR - and its theory- be worthy of attention? There is little account to individual commitment to serve humankind, their accomplishments or limitations. Therefore, this is what this chapter shall analyse.

\section{1- Peace in International Relations:}

About 10 years ago, Oliver Richmond published a book entitled Peace In International Relations (Richmond: 2008). His book explores implicit assumptions and some more explicit conceptualizations of peace in each theoretical strand of International Relations. Richmond's aim is to give sustainability to peace approaches within IR, drawing from the underpinnings of culture, development, agency and institutions in different theoretical ramifications.

The content of this chapter greatly overlaps with Richmond's work, particularly in the following aspects: approaching IR via the orthodox approach of "theoretical debates"; the "connection between theories, the ways of being, the knowledge systems and research methodologies" in terms of peace; "a broader interdisciplinary reading of peace"; and the more shocking lack of an explicit debate of peace (and not of war and violence) in IR theory. Moreover, my work in this chapter, like Richmond's, also explores how ideology, hegemony, dividing practices and marginalization are disguised as peace, and the very subjective nature of peace, which is not an "ontologically stable" concept. (Richmond 2008: p.2-5).

Having said that, my work parts ways with Richmond's when it comes to the methodology we use. Richmond advocates for a "methodological pluralism" as broader ways to explore peace without becoming parochial, which he cares to safeguard from an 
"irresponsible pluralism" as the dissolution of the discipline of IR per se (p. 6). Also, for Richmond

peace is viewed from a number of perspectives. It can be a specific concept (one among many): it infers an ontological and epistemological position of being at peace, and knowing peace; it infers a methodological approach to accessing knowledge about peace and about constructing it; and it implies a theoretical approach, in which peace is a process and outcome defined by a specific theory (Richmond: 2008 p.7)

However, the ontological and epistemological positions of being at peace that Richmond takes himself are nowhere explicit in his book, and thus not open for scrutiny and dialogue, which grants him the collection of several discussions and ideas of peace in IR, which are not properly tied together. Why is peace relevant for him? This personal and subjective nature of peace is not brought up for discussion, deflecting a conversation that includes his own peace, that evidences the purpose and suitability of his work. His effort of debating any kind of peace in IR in itself is already an important step, but insufficient in my eyes, and I find no evidence of why peace is relevant for himself. Without this orientation, any peace discussion can be co-opted.

As much as one can acknowledge the many perspectives to peace that Richmond mentions, in my work I ground my perspective in the fundamental aspect of love as service, as a mode of being and attitude that confers power to non-violence and peace, from which any criticism also derives. This is the reason why prior to and along with the critique of IR for its integration in peace studies, in the first part of this thesis I not only presented my own conceptualization of love but also discussed the idea of love in peace studies and how it has constituted an overlooked major aspect in it. This is an important step for a neater gaze from peace into peace in IR. This is where I part ways with Richmond with regards to the way we approach each theoretical strains of IR. 


\section{2- Love and International Relations:}

If, as discussed in part I of this thesis, love is a fundamental aspect of (holistic) peace/peaces, in order to incorporate International Relations into the epistemology of peace studies, it becomes fundamental to make visible the individuals behind the theory, tying together aspects of biography, ontological, epistemological and methodological elements of each IR theoretical strand explicit, to render visible how much these theories might overlook human relations, making explicit the author's engagement with the world hidden in their theoretical formulations. Only with such reflection, is it possible to consider whether such theories are geared towards a compassionate recognition of life and humanity and are of service to them or hinder them. On a par with a critical assessment of each theoretical representation of international relations, the aspect of love, its absence, or its relevance in IR theory can be drawn and elicited, pointing towards a transformation/twisting and critique of this discipline for peace studies. To every representation of the world, there is a correspondent representation of what it means to be a human-being and the place of love; however, it appears that IR seems to have traditionally ignored it, which has much to do with the effort to conceive of itself as a positivist (social/political) science. To bring a love perspective into IR is to make this discipline more humane - and also to deeply transform it - which may cause significant discomfort to more conservative audiences concerned with the maintenance of the world as they know it.

With this in mind, it pays to question how the traditional understanding of international relations came to be, followed by a subsequent placement of love within its theoretical debates. Thus, this chapter will follow a simple structure of providing a brief historical background of International Relations, present and contextualize its manyfold theoretical perspectives and their proponents, and along with each of them, a consideration on their account of love. 


\section{3- The case for psychology:}

Given the subjective nature of peace in this work, and the subjective implications in theoretical strands of IR, one may beg the question whether psychology would not be a suitable "filter" for IR into peace studies. Certainly, psychology could be considered an important lens, but a certain care must be put into the use of this lens, as I discuss in the following paragraphs.

In chapter one, I have made the point that from a perspective of holistic peace via Adam Curle, large-scale violence such as wars cannot be disconnected from individual violence, as they are all expressions of a black cloud. As violence is not simply an occurrence in the world out there but is manifested also within and through people's minds and ensuing actions - all of which feed the black cloud - one individual's allurement to certain kinds of violence is also a brewing of violence that should be taken into consideration. Therefore, my own life experience - including being an IR theorist, and my own psyche are important clues towards my proneness to violence. Therefore, my observation of the world through my own theoretical production serve as a doorway to raise awareness into possible "inbuilt" violence. This is clearly an entry-point for positing a dialogue with individuals about their own theoretical perspectives - instead of denying their perspectives and ignoring the individuals. This is especially important if as an IR specialist I assume the position of either informing relevant national policies or carrying them out from decision-making levels.

In international relations, Vamik Volkan was one of the first figures to connect individual psychology to large-group psychology as aspects that influence matters to war and conflict. Directly working with diplomats, government officials and statesmen as key figures into policy formation and the decision of waging war and engaging in violence, 
Volkan (2014) tried to approach the issue of international conflicts through psychological, and often unconscious aspects that catalyze violence, instead of coarser political, economic, legal or military violent actions alone. He sought to explain how individual and shared perceptions, thoughts, fantasies and emotions contaminate ones groups perception of international conflict events and thus prevent their transformation, in practice. Volkan started this enterprise through unofficial diplomatic dialogues between conflictive parties, after he started working with the American Psychiatric Association's Committee on Psychiatry and Foreign Affairs, after Egyptian president Anwar el-Sadat visited Israel in 1977. He declared that a psychological wall constituted a large part of the problems between those groups.

Volkan's (peace) work with large groups' psychological aspects within international relations aimed to be of service for diplomatic officials, considering diplomats as key individuals making fundamental decisions about whether engaging in war or peace, always informed by their respective groups psyche. Therefore, Volkan considers diplomats as relevant decision-makers. However, Volkan overlooks that in the high-level tables of international discussion, normally there is little space for individuals to sustain personal perspectives on peace and thus catalyze them, regardless of how well informed the diplomats in question are, as these officials mostly follow decisions previously made and in many ways, have their hands tied. Therefore, I consider diplomats not as decision-makers but rather as "decision officializers". Volkan's work with large group psychology puts too much weight on the role of diplomats, and could have a deeper impact if directed at the larger and more complex policy-making process. In so doing, his reflections would be pertinent also for groups of people working in the (distant, medium-level) observation and inception/creation/orientation of State politics from a desk-table perspective - such as foreign policy theorists and IR analysts (and track-two diplomats, also known as 
academics). In this way, he would be addressing the deeper-seated aspects of conflict and violence which are catalyzed especially from behind the curtains of foreign policy, and down to the personal level of international theory makers, especially if they are themselves not involved in any sort of track-two diplomacy. This level of complexity and systemic inter-relating was lacking.

Also, Volkan's work takes the diplomatic work in its classical sense, as individuals working to prevent conflicts that mobilize entire societies against an external "enemy". Yet, as Mary Kaldor pointed out in New and old wars: organized violence in a global era (1999), this conception hardly is the case of conflict and violence in the international domain in contemporary times. It would be possible to assume that post 9/11, with The National Security Strategy of the United States of America (2001), the US government tried to mobilize world politics towards a war against an external enemy of terror, just like conventional wars placed enemies outside their own territories. However, this new external enemy of terror does not have a proper shape. It refers to networks that cross boundaries and are not as easily identified as territories or Nation-States. Therefore, they cannot be addressed in conventional IR theorizing. The relations between such a "war on terror" and the US population's psyche certainly remains a relevant analysis, but there might be more relevant ways to address its impacts rather than focusing on diplomacy.

In other words, Volkan's effort to link psychology and international relations did not translate into an encompassing link between psychology and IR-theory-making/makers within research settings, something which has prevented IR from a meaningful transformation towards a more holistic perspective of peace studies (remembering peace to be the aim and purpose of IR), in which the individual perspective of peace is connected with the peace out there in the international realm. 
Therefore, if IR-theory is to be introduced, "taken" into such holistic perspective to peace-studies, IR-theory needs to also pass through this filter of psychology. Not for the sake of peace-washing IR theory, but particularly for the opportunity of engaging with those that (re)produce IR unaware of all the psychological noise which their lives and experiences bring into international relations, exploring peace with those who become entrenched in certain theoretical strains closed to dialogue. In this chapter, this is the point in which the perspective of love addresses not only theory alone but also those people who engage with IR theory. This is done certainly via their thoughts and theoretical ideas, but with a care towards underlying subjective perceptions, fantasies and emotions induced and felt by their IR theory, and what is brought to peace studies from a conversation of this type.

\section{4- Origins of International Relations:}

While it can be said that international relations have existed from the moment two state-like territorial entities - such as the Greek City-States illustrated by Thucydides in the History of the Peloponnesian War (2007) - have had political contacts with one another, International Relations as a discipline has only emerged in the twentieth century. It was the scale of deaths caused by World War I (WWI) that motivated intellectuals to theorize how to avoid wars and how to avoid the repetition of the bloodshed seen between 1914-18 - 10 million casualties and 20 million wounded according to Antoine Prost (2014). It seems hard, however, to conceive of someone at the time in good spirits enough to theorize the prevention of war after the level of violence and horror experienced during WWI. Ironically, three decades later World War II would take a much heavier toll: 50 million (Keegan: 1989). 
How much trauma, pain, fear, despair, bereavement and rejection has not made their way up to the formation of International Relations as a discipline? The history of Posttraumatic Stress Disorder dates back to the end of Wolrd War II but the fact that this diagnosis first appeared with a different name in 1952 as "gross stress reaction" does not mean that their symptons did not take place before (Andreasen: 2010). On top of the challenging reintegration of surviving combatants after diagnoses of shell shock, chronic fatigue, disturbed sleep, headache, depression and anxiety (Engel: 2004), the scale of the First World War meant that most non-combatants in Europe were affected by it to some degree - experiencing hunger, displacement, imprisonment, becoming widows and orphans (Bessel: 2017). Therefore, it is only through very hard to accept - if not unrealistic Cartesian lenses that one could ever actually detach onelsef from this general struggle and ignore this collective intersubjective experience of hurt to put ahead a project of a theoretical reflection on wars claiming to be objective and unrelated to one's context. At the same time, this project may have been aroused by a much needed - but unconscious process of healing. This process, nevertheless, was terribly ill-conceived in practice: making war the leitmotif of a discipline blocked understanding of war and violence as a state of exception of human life, leading to a fixation with war (and thus violence) and seeing them everywhere -as discussed further in this chapter.

If addressing trauma on an individual level already is a difficult task, to address it collectively is a much larger challenge, and addressing people experiencing requires a careful and skillful approach. Along with its claim to be regarded as a hard social science with its according methodological care, I can sense how such trauma has allowed International Relations from its very inception to be de-humanized - as to avoid touching sensitive matters. In fact, IR aimed to address the abstraction of the state in relation to other states as if they meant the same as their peoples and their struggles and traumas. Even if 
behind any process of state-crafting there are human-beings with a common identity trace longing for peace (which does not imply the same as security), a state does not equate to its citizens and its creation does not guarantee absolute safety. At best, what is experienced is negative peace. The focus on states blurs the fact that, prior to inter-state relations, several relevant discussions remain open: How do human beings respond to the reduction of their free will into a set of structures defining their behavior and reducing their personhood into citizenship? No matter how traumatized by war and violence I might feel, there is something about the experience of being human that cannot be reduced to subjecting my own life to an abstract notion of a political entity to regulate my own thoughts and feelings and derivative action, that refuses to have my own views obliterated into political intention/strategy, and this cannot be overlooked.

In this manner international relations became a discipline, mostly through the combination of disciplines such as Political Theory, Law, History, Geography and Economics, which aimed at explaining the several domestic and international processes related with war - overlooking the diversity of their citizens or taking the plea of the majority. The approach was to create theories that could explain, foresee or regulate the behavior of states in the face of an international system devoid of authority. At this point, a closer look into IR's theory helps to understand the avenues the discipline has paved and its many cracks, particularly when it comes to understanding the way love and loving challenges these very theories. IR theory has been a staple of my bachelor degree in IR, and much of what I review ahead is a reflex of the first textbook on IR Theory written in Portuguese, by my former teachers João Pontes Nogueira and Nizar Messari (2005). 


\section{2- Idealism:}

As mentioned above, people directly involved with World War I had realized the scale of its atrocities, abhorring what they had done. In the effort of acknowledging what people had done (if there could ever be any justification to the generalized and systematized violence of war), it was convened that people could only resort to war if they borne a great injustice or if they were governed by ill-intentioned people. Underneath this assumption rested a certain liberal belief that democratic political regimes were guaranteed to be peaceful. The reason being that in those regimes people decide their interest, and would be against being brought any form of violence. In this logic, the war that nevertheless happened seemed to be caused by tragically poor diplomatic strategies and the inability to bring about satisfactory political agreements, in the case of WWI, over the unrest caused by the death of Francis Ferdinand.

Thus, the post-WWI environment led into pro-international democracy discourses that favored the creation of an international institution that could provide a sense of collective presence, security and avoid/regulate war, whenever democratic regimes failed to escape it. This had given rise to a certain naïve conception of the world, one in which the phenomena of war could easily be addressed through an institution that would regulate the mechanism of international politics. At the time, a series of treaties along with Versailles, such as the Locarno Treaties, and the Kellogg-Briand Pact, seemed to confirm the tendencies of managing peace exclusively through high politics.

And, in a logical step, along with this political strategy, it became important to develop educational programs that created specialists carrying out research onto the causes of war and how to avoid them. Consequently, the first program of IR was created in the University of Wales at Aberystwyth and was named after Woodrow Wilson, the visionary behind the League of Nations. This initiative was soon followed by the chairs of 
international politics at Oxford University and the London School of Economics (Brown: 2005 p. 22). Their aim would be to spread the rule of international law and its governing institutions.

Idealism, as the very first theoretical view of IR worked a simplistic means of burying the pain and the crude reality of the war just recently experienced into robust institutions. But idealism, as its own concept implies, does not focus much of what actually is taken place or the complexities of the world. And it would eventually be accused of disregarding what actually went around the minds of people, be it policymakers or those directly affected by war. It is importance to note that, on the side of the victims, the climate around France was of revenge against Germany for all its losses, despite France won the war. On the side of punished perpetrators, the discontent with the unilateral blaming for the war and the heavy reparations imposed on the Germans was widespread. Both feelings seem at odds with an idealism that could curb growing dissatisfaction, on top of a brewing victimhood from the pain caused by war that could (would) easily transform into violence one more time.

It so happens that the realization of war as the most dehumanizing action may not be enough to curb one's aggressive tendencies and one's need to act on it. Likewise, it is not enough to create institutional mechanisms to prevent war, or trust that democratic political regimes would autonomously act in a more peaceful manner. I find it fundamental to remember that institutions and political parties that determine political regimes are made of human beings and that it is possible to have a large scale inter-subjective peace buildup, though that is extremely arduous and requires constant individual check-up. Part of human nature is the experience of those human potentials for violence manifested above all into micro-conflicts, as Paco Muñoz noted (see chapter II). It seems that unfortunately 
there is no easy-answer to the complexity of human subjectivity and how conviviality can adjust itself around it. This is particularly so on a large scale as IR aims its focus.

In this light, for idealists, peace is actually something one "achieves". But even if this peace can be achieved, it would also need to be a lasting one. If I go along with this argument, to actually sustain peace, idealists perhaps should go through the effort of addressing themselves and others in their full humanity, recognizing that aggression and violence are a misfortunate but an all too human (re)action, and that working with it and acknowledging it has a more meaningful impact in terms of sustaining peace when compared to rejecting, condemning, and punishing such misfortune. To use Curle's language, rejection, condemnation, and punishment are ways to feed the black cloud. It would be different, though, if one could respectfully communicate disagreement, critique of behavior and policy and explore tactical defenses if there is need for it. That is a compassionate attitude that has to be continuously reenacted, recalling the need to be critical of reality and at the same step beyond the apparent horizon of possibility, as highlighted by Paulo Freire.

\section{3- Realism:}

The idealism put forth by Woodrow Wilson through the League of Nations came, however, soon to an end. The assumption that remaining international issues would be settled in terms of peace just because people strove for peace could not be farther from what the subsequent historical events showed. While non-democratic regimes in Spain and Russia and particularly Germany seemed to confirm the idealist premise that only these kinds of regimes would enter war (either civil or inter-state), idealism could simply explain fascist Italy and Nazi Germany, where there was ample support for war (Brown: 2005). 
Reacting to the idealism that informed IR and the political sphere after the World War and at the brink of World War II, Edward Hallett Carr started questioning the assumption that people did not wish for war- in a place and time where the tensions seemed like they were doomed to explode at any moment. Carr served at the British diplomatic corps and participated in the Versailles treaties, and later as an IR scholar at Aberystwyth. The overall environment that Carr found post-Versailles rightfully led him to question whether the pure desire for peace expressed in the treaties and in common parlance would actually lead to it - a desire that the popularity of Hitler's and Mussolini's governments have demonstrated belonged to just a silent few. Carr argued that this striving for peace could not make analysts blind to the glaring evidence that power was at work after the war and that this power did not seem to be geared towards peace. In The Twenty Years' Crisis (1946), Carr addresses the frustration he felt with the naiveté in which IR was approached in its conception, and considered that to reach maturity, IR had to come to terms with "reality":

The impact of thinking upon wishing which, in the development of a science, follows the breakdown of its first visionary projects, and marks the end of its specifically utopian period, is commonly called realism. Representing a reaction against the wish-dreams of the initial stage, realism is liable to assume a critical and somewhat cynical aspect. In the field of thought, it places its emphasis on the acceptance of facts and on the analysis of their causes and consequences. It tends to depreciate the role of purpose and to maintain, explicitly or implicitly, that the function of thinking is to study a sequence of events which it is powerless to influence or to alter. In the field of action, realism tends to emphasise the irresistible strength of existing forces and the inevitable character of existing tendencies, and to insist that the highest wisdom lies in accepting, and adapting oneself to, these forces and these tendencies. Such an attitude, though advocated in the name of "objective" thought, may no doubt be carried to a point where it results in the sterilisation of thought and the negation of action. But there is a stage where realism is the necessary corrective to the exuberance of utopianism, just as in other periods utopianism must be invoked to counteract the barrenness of realism. Immature thought is predominantly purposive and utopian. Thought which rejects purpose altogether is the thought of old age. Mature thought 
combines purpose with observation and analysis. Utopia and reality are thus the two facets of political science. Sound political thought and sound political life will be found only where both have their place (Carr: 1946, p.10).

Carr considered Idealism to be a form of utopia, which would be most blatantly expressed in its zeal for a form of moralized ethics. At the same time, he claimed that ethics had to be understood as politics, where only the observed political phenomena should determine behavior. Furthermore, Carr considered that it was hardly possible to ask States to engage with each in terms of compassion, which should at best be reserved to their own citizens or only possible between individuals. And, in a context in which societies were preparing themselves for war, it is only natural that realism will provide an aesthetics of political violence, based above all on the critical resignation to what is "reality". It is in this way that Carr retrieves Machiavelli and Hobbes and thus provides the foundation of the image of Realism.

Yet it was Hans Morgenthau in his Politics Among Nations - The Struggle for Power and Peace published in 1948 that shaped Realism into a deep-rooted image of IR by setting its premises on the issue of power - understood mostly as military power. Morgenthau was born in 1904 in a Jewish family from Coburg, Germany. Before having to flee Europe to the United States of America (USA) due to the Nazi expansionism and World War II, Morgenthau had already endured forced migration from Madrid, Spain, after Franco's regime was installed. In both instances state and governmental power significantly altered his life.

In the opening paragraph of Politics Among Nations, Morgenthau declares:

This book purports to present a theory of international politics. The test by which such a theory must be judged is not a priori and abstract but empirical and pragmatic. The theory, in order words, must be judged not by some preconceived abstract principle or concept unrelated to reality, but by its purpose: to bring order and meaning to a mass of phenomena which without it would remain disconnected and unintelligible. It must meet a dual test, an 
empirical and a logical one: Do the facts as they actually are lend themselves to the interpretation the theory has put upon them, and do the conclusions at which the theory has put upon them, and do the conclusions at which the theory arrives follow with logical necessity from its premises? In short, is the theory consistent with the facts and within itself? (Morgenthau: 1997, p.3)

Through my critique of Idealism, I have already discussed the question of whether or not objective observation of phenomena is titillated by one's own life-experience and subjectivity and then discarded if not befitting the idealist's wishful thinking; this puts into question positivism as a deliberate exclusion of facts that influence perception but which are discarded in order to not compromise purported objectives. Meanwhile, in Realism, in the opening paragraph of Politics Among Nations, Morgenthau takes a step further and states that this realist theory of his must be confirmed by concrete observable facts, avoiding idealist denial. While idealists reject and deny what does not conform to their goals, Realists run the constant risk of overlooking what does not conform to their theory, and, whatever is not factual and objective becomes irrelevant. In addition, if Morgenthau's premises are based on his own subjectivity, it is hard to imagine that a person with a certain tendency to see phenomena under a certain light is not biased enough to see the same phenomena more often than it appears.

Idealists are informed by a fundamental hope that the present and future can be better; Realists are informed by a fundamental resignation to focus on what feeds their hopelessness. This resignation becomes ever more explicit when Morgenthau discusses "the problem of peace in our time" (Morgenthau: 1997, p.417-418). In this discussion, Morgenthau provides an idyllic picture of the Enlightenment and liberalism and how it all was destroyed by the Napoleonic Wars and the French Revolution, leading to quests for security, arms control, an international police force, et cetera. Sadly, peace, for Morgenthau, would require far too many conditions both domestically and internationally 
- a perspective challenged by Martínez Guzmán in Podemos Hacer las Paces (see chapter 2).

Regardless of the critique it received - or precisely because of it, Politics Among Nations became one of the most influential books in International Relations for positing the principles of Realism, as follows:

1. Political Realism believes that politics, like society in general, is governed by objective laws that have their roots in human nature. (...)

2. The main sign post that helps political realism to find its way through the landscape of international politics is the concept of interest defined in terms of power. (...)

3. Realism assumes that its key concept of interest defined as power is an objective category which is universally valid, but it does not endow that concept with a meaning that is fixed once and for all. The idea of interest is indeed of the essence of politics and is unaffected by the circumstances of time and place. (...)

4. Political realism is aware of the moral significance of political action. It is also aware of the ineluctable tension between the moral command and the requirements of a successful political action. (...)

5. Political realism refuses to identify the moral aspirations of a particular nation with the moral laws that govern the universe. (...)

6. Political realis $[\mathrm{m}]$ is not unaware of the existence and relevance of standards of thought other than political ones. [Political realism] cannot but subordinate these other standards to those of politics. (Morgenthau: 1997, p.4-16).

In this sense, Realism is the continuation of the interpretations of political conflict as a struggle for political and military power enmeshed with violence in the tradition of Thucydides and, more particularly, Thomas Hobbes. In that regard, the question that love poses is whether one has to become a hostage of one's cynicism to approach politics through fear and violence. In terms of values, a peace perspective geared by love seeks to address and understand political action through collective compassion and service, which needs not to be naïve, and may find creative responses and expand the narrow focus of political power and violence into other dimensions of a complex existence. 


\section{4- From Realism to Behaviorism and the English School Critique:}

The horror of war granted the Realist school of IR to establish itself as its main current, making several IR scholars consider that realism won the debate with idealism. At this point, the realism advocated by Carr and Morgenthau yielded so much power within IR that soon scholars started questioning and refining what had become known as its classical form.

One of those voices critical to Carr and Morgenthau's realism was that of John Herz. Similar to Morgenthau, Herz also belonged to a Jewish family that fled Nazi Germany, having established himself in the US in 1938. Before exile, John Herz was known as Hans Hermann Herz, and first approached international relations through its legal aspects, influenced by his doctorate supervisor Hans Kelsen. In fact, Herz followed Kelsen to Geneva to work at the Graduate School in Geneva (IHEID) in 1933, after he was forced to leave Germany. But while Kelsen's research interest relied in pure forms of law as processes to be devoid of human inclinations, it was clear to his student that the charged environment of Europe pre-World War II pushed him to consider how it was dangerous to have one's head in abstract pure forms of law, particularly when the law practiced was instrumental to several forms of state-conducted violence. (Hacke \& Plugierin: 2007)

In his 1950 Idealist Internationalism and the Security Dilemma article, Herz demonstrated the same frustration as Edward Carr's in relation to the utopianism that had marked the inception of International Relations. At the same time, Herz distanced himself from the cynicism of a realist world because even if he assumed the world to be as such (particularly with the failure of the League of Nations, the rise of Nazism and Stalinism), Herz felt at heart that it was wrong. Instead, he proposed a conception of "Realist Liberalism" (p.179) that defended people's (and nations) own will to support each other 
and deter totalitarianism, which was an actual threat during his time. This Liberalism was different from $19^{\text {th }}$ century's liberalism because for Herz it could give way to careful and lucid observations on State behavior and insecurity and thus could create the possibilities for a proper instrument of/for collective security. This liberal observation of a dilemma and choice of action would eventually pave the way for behaviorism and its influence on International Relations.

However, it was Kenneth Waltz's 1959 book Men, the State and War: A Theoretical Analysis that opened the debate of behaviorism in IR, as an attempt to organize the study of International Relations and inter-state violence. The book's main argument was that the causes of war (and ways to prevent or counter it) could be found in three different levels or images: human behavior, State behavior and, finally, the anarchic international system. Since this third level is best represented in Herz's security dilemma as the behavior of states in a context of anarchy, I concentrate on an explanation of the two first levels below.

According to the first image of international relations, the locus of the important causes of war is found in the nature and behavior of man. Wars result from selfishness, from misdirected aggressive impulses, from stupidity. Other causes are secondary and have to be interpreted in the light of these factors (Waltz: 2001 p.16)

It is in the first image of war that the causes of war are found in the texts of Morgenthau and other authors in the tradition of Thomas Hobbes. In this image, war flourishes in men's evilness. For Waltz, it was a matter of addressing psychic-social or moral-intellectual in order to develop individual goodness and prevent war from happening or to stop it. Waltz notes that in this image, the difficulties were in translating behavioral change into individuals to the point of impeding war, as he carefully analyses whether behavioral changes are possible in the face of politics that very often condition one's aggressive response to the world. With this argument, Waltz seems to point to what in peace studies could be termed conflict transformation, developing awareness of one's bias and 
how it brings about violence. The problematic aspect of his approach, however, resides mostly in the language being used, in which behavior change does not entail a meaningful transformation and liberation but is only about conditioning, amounting to a repetition of a pattern, no matter how good the intentions behind it are, and this extirpates human agency and creativity. Controlling human behavior does not transform conflicts and therefore does not stimulate a human process of unfolding.

In the second image, Waltz poses that poor governance is the key to war. In a shift from psychology to politics as a level of analysis, in this image, war would be either caused or prevented by the kind of governance of any given state, as the form of social organization that conditions societies. Yet, Waltz notes that the concept of good governance will significantly vary between liberals, militarists, imperialists, and even Malthusianism as forms of government that could influence war and peace. In this sense, governments could be either peaceful, aggressive or neutral. The political analyst, thus, would simply have to medicate society as a patient who suffers the illness of aggressive behavior. Furthrmore, he points out that one possible approach is to curb the influence of political elites and how they shape the larger public. This amounts to a concept of peace close to moralism, which again seems far from trusting human potential and unconditional loving.

It was clear for Waltz that none of the images could alone explain the causes of war, as he regarded that each of them was incomplete and partial. Such partiality was to be regarded as a quality that functioned almost as a drive towards the inclusion of others in a more complex arrangement. This approximates his ideas to Muñoz's imperfect peaces, if it was not for Waltz's excessive focus on war when talking about peace (discussed in peace studies' epistemological turn) and his focus on behavior rather than on consciousness.

Still, the behaviorist take on International Relations would recrudesce with J David Singer. Singer was the creator of the Correlates of War (COW) Project, a project that aimed 
at "assembling a more accurate data set on the incidence and extent of inter-state and extrasystemic war" (Correlates of War Project: 2019) in order to offer an analytical model with reliable prediction of where tensions towards war could gather. Singer focused thus on the observation of patterns in hostile intentions, measured by military capability and war intents (Singer: 1961a). In "Waltzian" terms, this would amount to focusing on the third image, discarding attention on the first and second images, for the sake of a homogenized approach and "stable perspective, thus he proposed understanding States as opaque - as "black boxes" or "billiard balls" (Singer: 1961b, p.81).

Singer's project seems like a good excuse for a fetishism with data gathering systems. And, if there is a critique to be made from a love perspective focusing on humanity to the behaviorist influence over Realist thought, particularly the one Singer proposed, it is that his initiative needs at a minimum to be complemented with an account of peace, of human agency and of human potential, which already are assumptions possible in a systemic perspective. Without agency and potential, Singer's analysis is doomed to be a myopic one, and the insights of the epistemological turn in peace studies (that we can "make" peace), stand as a relevant critique towards his thought. Another relevant critique rests in the fact that by enclosing intra-state dynamics - which he acknowledges as relevant but overlooks in his analysis, International Relations as such loses touch with reality, with the lives that people carry out on a day to day basis. Although Singer meant his study to provide evidence of violence in the international sphere as inputs for policy that would prevent war and thus preserve those lives (a legitimate concern over peace which one could assume was to be complemented with the works of his colleagues such as Anatol Rappoport and Elise Boulding - see chapter 2), his concern is indeed only limited.

In any event, Singer's quantitative analysis of wars and the overtly scientific tone of the behaviorist turn in IR caused great frustration with other IR scholars, demonstrated 
particularly in Martin Wight's work: “[t]he idea that an approach to Theory as unhistorical and unphilosophical (...) simply never entered his head" said Wight's former student Hedley Bull (Wight: 1996 p. xi). In International Theory: The Three Traditions (1996) a posthumous book organized by Bull from a series of lectures Wight gave in the 50s, Wight sought to organize the study of IR through what he considered the three main traditions of thought in IR: Realism, Revolutionism and Rationalism, which would be best represented by the works of Niccolò Machiavelli, Immanuel Kant and Hugo Grotius. In this way, he analyses the perspective of human nature, international society, humankind, national power, national interest, war, diplomacy, law and ethics and so on. The work is organized in a way that Wight flirts at times with each of these traditions, in an effort to understand their arguments without ever boxing himself into any of them.

Considering the premises of Realism already laid out in this chapter, I can focus briefly on Wight's perspective over Rationalism in the Grotian tradition and Revolutionism (idealism) in the Kantian tradition: The revolutionists deny Realism's pessimism over humankind and stress a consequent international society. As the other side of the coin of Realism, it amounts to a wishful thinking on the brotherhood of mankind and on an international society that will often take shape of self-righteous proselytism - if not coercive on a perspective in which everybody must be equal, tragically overlooking difference. For Wight, Revolutionism was best expressed in Kant's Perpetual Peace in which the doctrine of uniformity and ideological homogeneity was expressed in republicanism (Wight: 1996 p.42). This clearly represents a certain form of well-intentioned form of imperialism. At this point, it is worth mentioning that more often than not love for others is interpreted in this way, amounting to a total disregard of one's autonomy and freedom, reducing alterity to personal projection. For the Rationalists, however, there is a mid-way between the realist's pessimism and rationalist's euphoria, balanced by reason, and for rationalists 
humans hold the capacity to be either vile or ingenious in their social relations, placing in caution the better measure. Regarding an international society, whereas realists see a lack of regulation that amounts to war (no society at all), and revolutionists see an imperative of fulfilling a prophecy of reaching heaven, rationalists believe customs and traditions - in e.g. law - provide a basis for social conduct, regardless of these customs being flawed. For them, states, as fictions of human collectives, could be civil as long as humans did so, and this aspect of fiction of human collectives need to be more stressed.

The rationalist concept of international society organizing itself in the face of anarchy that Wight lays out became central to what has been known as "The English School" of International Relations, whose main exponent is Wight's former student Hedley Bull. Bull's book The Anarchical Society: A Study of Order in World Politics, first published in 1977 has become a classical representation of the English School. In a way, English thought can be considered the heirs of the Grotian Rationalists that Wight first described. In The Anarchical Society (2002), Bull discussed the matter of international order, pointing that anarchy is not necessarily a state of war in which states seek absolute power (distancing himself from Realists), but that States remain the starting point of international order.

For Bull there is plenty of historical evidence that States cooperate with each other and recognize common sets of rules, either as law or as morals, providing a sense of belonging to a certain group that has a certain way of doing things that could be considered ordered. In these situations, one indeed can speak of an international society. But this society does not mean its own rules are unchanging (thus also distancing himself from Revolutionists). Therefore, what is put in question by Bull is the value of rules and the points up until they do not. In order to infer those thresholds where rules are suspended, transformed or no longer are valid, it is fundamental to consider the historical patterns of 
behavior and relations of States that allow one to describe if a certain set of States belong to a society and which other states (or other non-state actors) do not.

In this point of belonging, it is interesting to notice how Bull highlights diversity as part of the international system - for states have never been the rule but only a more common pattern of organization in the past century. The problem is that this recognition of difference stems not from a celebration of it and knowing how to relate to difference, but from a categorization suiting egoistic interests in order to pragmatically reach them: it is a calculus that just acknowledges difference in order to evaluate if the context of anarchy is positive for oneself or not, thus quite self-centered. It is as if I could only trust people if I fully scrutinized them completely and assessed their value according to my needs, objectifying others. The mistrust inbuilt in this perspective demonstrated the mechanism of always holding comparative advantages which leads one to never make any compromise and never expose any vulnerability, and thus never opens the possibility for deeper connection.

This English softened version of Realism (for mistrust is a form of fear) laid out by Bull presents itself as problematic inasmuch as this distanced observation of international politics is in no way titillated by the author's personal regard of ethics and how to act either within an international society or an international system, which amounts to pragmatism. In The Anarchical Society Bulls makes too little a consideration on ethics, only about law as the shaper of pragmatic behavior. In his own words:

It may be conceded that the work of judges, legal advisers and legal scholars in interpreting existing legal rules is in fact always influenced by their views on social, moral and political questions. It may be conceded also that it is not only inevitable, but also desirable, that international lawyers take account of these non-legal considerations in interpreting the law (...). But if a distinction is not preserved between those rules of international conduct which have the status of law and those which do not, international law cannot survive as a distinct normative system at all (Bull: 2002 p.153). 
In the excerpt above Bull concedes to ethical stances but differentiates which kind of behavior may pass unpunished for not necessarily breaking the law, which is a cautious measure from a core of fear. This becomes detrimental to nurturing relationships for one is always anticipating what could go wrong and how to better protect themselves, or at the very least take measure only if others do. In sum, there is no space for an altruistic attitude in such a perspective and, sadly, through this perspective human values are rendered meaningless, emptying international politics of humanity.

\section{5- The influence of Political Economy in IR: (Neo-)Liberalism,}

\section{Neorealism and its (Marxist) critique:}

Behaviorism dislocated the (classical realist) debate of international relations in interconnection with human nature (how states relate to each other reflect how humans relate to each other) to a debate over the pattern of behavior that entirely abstract entities have in relating to each other (Interstate-violence through quantitative analysis as with David Singer). Meanwhile, the English critics highlighted the weight of tradition (in terms of rules and norms) shaping those entities (as with Wight and Bull) in the face of anarchy, bringing again a proximity between the concept of the State and human (forced) socialization, drawing close to the cultural aspects of civility.

The international politics dynamics taking place after the Second World War, however, could be very accurately read as a military power struggle, in which the US and the Soviet Union (USSR) as two centers investing in an arms race in order to maintain a delicate balance of power. This reflected both Realist and English claims and also provided a frame for behaviorists in IR. The arms race that took place in that period, represented in the Strategic Defense Initiative which became popularized as Star Wars, gives good 
evidence that Realist claims remained sharp. At the same time, the English Perspective, which acknowledged the ontological plurality of the international realm and defended articulating pragmatic state behavior, read the clash through the differentiation of sociopolitical traditions between states in the capitalist versus communist clash, and also provided an account of the third world and the non-aligned movement.

Yet, both perspectives overlooked the relevance that ideology gathered in explaining international politics during the Cold War. After all, capitalism and communism are not simply socially convened practices as the English school would have referred it to. Ideology means more than simply traditional ways of relating. At the same time, the Cold War was not only about an arms race of competing powers as the realists advocated. The Cold War was, to a large extent, a representation of the clash between capitalist and communist ideals invested in the State apparatus, more specifically, about the philosophies of liberalism and Marxism determining politics. Thus, it is important to analyze the role of those philosophies within IR theory-making, and ahead I discuss the ideas of Liberalism, Marxism in IR and a Neo-realist reaction to those perspectives.

\section{1- Liberalism:}

Liberalism represented a way of conceiving the world based on man's (sic) individual role in shaping their society according to what was considered their natural rights: life, freedom and private property - in a most Lockean conception (Locke - Second Treatise of Government). In Liberalism, the problem resided in the way men could organize themselves in a rational way in order to maximize personal or private benefits and minimize costs - leading to an ego-centered concept of being human which was considered a pathway into a developed society. For liberals, my self-interest translated into cooperation with others: Adam's Smith's concept of the invisible hand (Smith: 1977, p. 593) meant 
precisely that self-interest and enrichment always translated into general well-being insofar as it inclined people to find a niche in which they could also become prosperous, as if an invisible hand made sure society would organize itself on its own and keep on the track of progress.

In this perspective, war remained a problematic idea insofar as it had costly impacts on man's self-centered pursuit of ever-growing capital affluence, as it would hamper the natural flow of the market that allowed for it. In a pragmatic move, it is from this perception that liberalism opened space for the belief that societies could regulate themselves through institutions that would address any problems that affected the free flow of the market. Liberalism, like in Martin Wight's revolutionists' perspective, draws extensively on Immanuel Kant's philosophy. It is not surprising to understand here the influence Immanuel Kant's own biography had on his thought and on the thought of his followers, providing a basis for Liberalism. Kant was born in Königsberg, a Prussian city part of the Hanseatic League, a confederation of traders and merchants that controlled the North and the Baltic seas, which protected the interests of its members in their trading routes.

Kant advocated precisely for a federation of republics as a form of government that politically organized human relations in a way that their citizens would have their voices in favor of self-preservation heard, in order to remain conducting business as usual. Peace would be the ideal condition for business and profit to take place, and war would mean a terrible cost, countering any tendency towards war and violence:

the Republican Constitution, in addition to the purity of its origin as arising from the original source of the conception of Right, includes also the prospect of realizing the desired object: Perpetual Peace among the nations. And the reason of this may be stated as follows. According to the Republican Constitution, the consent of the citizens as members of the State is required to determine at any time the question, 'Whether there shall be war or not?' Hence, nothing is more natural than that they should be very loath to enter upon so undesirable an undertaking; for in decreeing it, they would necessarily be resolving to bring upon themselves all the horrors of War. And, in their case, this implies such consequences 
as these: to have to fight in their own persons; to supply the costs of the war out of their own property; to have sorrowfully to repair the devastation which it leaves behind; and, as a crowning evil, to have to take upon themselves at the end a burden of debt which will go on embittering peace itself, and which it will be impossible ever to pay off on account of the constant threatening of further impending wars (Kant: 2010 p.8).

And, regarding the relations posed between States, Kantian Liberalism holds that international institutions become ever more important: to regulate those relations in the international realm so as to maintain peace.

the state of Peace cannot be founded or secured without a compact of the Nations with each other. Hence there must be a compact of a special kind which may be called a Pacific Federation (foedus pacificum), and which would be distinguished from a mere treaty or Compact of Peace (pactum pacis), in that the latter merely puts an end to one war, whereas the former would seek to put an end to all wars forever (Kant: 2010 p.11).

Through Kant, the aim of peace became the combination of a view of humans as ego-centered beings (that act rationally so as to maximize their profit gains) and a form of government that not only legitimates this conception but also seeks treaties on the international realm to perpetually establish this state, legitimating the liberal-capitalist ideology that the US came to represent during the Cold War. In addition to that, the attention to processes such as globalization and the revolution in communications - which many authors consider as the main feature of the second half of the twentieth century (see Giddens: 1991; Held: 2003; Friedman: 2007) - furthered liberal perspectives by giving prominence to transnational entities pursuing capitalist interests. This global stretching of the relations between countries in the shape of an international market supported by international institutions such as the World Bank and the International Monetary Fund highlighted the influence of capital and trade in international relations.

The development of Capitalism from the gold pattern up until nowadays, in the form of a discourse within international relations has been analyzed particularly by Robert Gilpin 
in his 2001 book Global Political Economy: Understanding the international economic order. For Gilpin, the increasing role of multinational corporations since the 80 s started dramatically changing international relations (2001: p.6).

It is in this regard that authors like Joseph Nye and Robert Keohane published a series of essays entitled Transnational Relations and World Politics in 1971. From the onset they emphasized that they were "interested in a wide variety of transnational phenomena: multinational business enterprises and revolutionary movements; trade unions and scientific networks; international air transport cartels and communications activities in outer space" (Nye and Keohane: 1971 p. 331), and how these entities affect world politics by changing and shaping even interstate relations.

In the work mentioned, Nye and Keohane discuss that transnational organizations might promote attitude and perception changes between nationals of different countries, thus affecting their business and the possibilities for peace. They also promote plurality in the international arena through international non-governmental organizations (NGOs) and their agenda. Transnational organizations also promote a great deal of dependence or interdependence between states, as policies in a country affect their businesses' interests and investments in different regions or even cause migration. Transnational businesses also influence weak and fragile states, by imposing their interests and sometimes serving as instruments of one government's interests.

While Nye and Keohane provide an accurate account of phenomena taking place in the world, they mention that state-centric theorists did not ignore those aspects of international relations, but deliberately excluded them because of the indirect or subtle way in which they affect state relations, which is considered the core or main actors of international relations for most IR theorists. They perceive the problem rests on the traditional definition of politics as something pursued only by states, and thus they advocate 
a broader definition of politics: "We therefore prefer a definition of politics that refers to relationships in which at least one actor consciously employs resources, both material and symbolic, including the threat or exercise of punishment, to induce other actors to behave differently than they would otherwise behave" (Nye and Keohane: 1971 p. 344).

Nye and Keohane consider that the myopia of traditional state-centric theorists onto the complex dynamics of the world is problematic because it prevents traditional policymakers are to grasp the unequal distribution of power in the international system in order to maintain control of and pursue their interests (Nye and Keohane: 1971 p. 721-722). While Nye and Keohane's perspective offers a great insight into a more complex and plural international domain, they stress that they solely aim at providing empirical evidence of those dynamics, removing themselves from providing a personal opinion on abuses of power and long-term influence of private transnational capital in society. Whereas a perspective of unconditional love trusts the human commitment towards finding balanced relations, and trust people to find their own potential for addressing the lived reality to experience peace, whenever I perceive the unequal relations between large corporations and workers widening the gap between a small affluent group of people and a much larger group of people living in a precarious and vulnerable condition, it becomes a personal challenge of mine to observe those dynamics and trust people's power for transformation without putting into question my personal responsibility into that situation. And even if in this specific case my perception is a reductionist one that does not account for the richness of life other than in material terms, even if peace is unconditional, whenever some aspects that inform it are continuously denied, it becomes a big challenge for my own self to actually experience it. It is in this light that the aspect of compassion in love - or loving comes into play, to engage in whichever conflicts are perceived by the groups I am connected with without the removal that the liberal perspective embodies. 


\section{2- Neorealism:}

The growing influence of economic matters in international relations and its consequent reflection within International Political Economy influencing IR found a most detracting reaction within IR theorists. While Liberalism emphasized a complex and interdependent world, Neorealism stressed yet again the relevance of a power-oriented state-centric perspective in world politics. Within Neorealism, John Mearsheimer, professor of political science at the University of Chicago, came to represent its most prominent voice. Answering how he ended up defending a realist approach, Mearsheimer comments that he was very affected by the 10 years he served in the US American army in the Vietnam war. After that, in comparison with Liberalism and Marxism, only Realism seemed to provide an accurate account of what Mearsheimer lived in the world (Schouten: 2012).

Following Realism's state's orientation towards power, Mearsheimer considers that the economic power produced by capitalism and yielded by liberals as the sign of a cooperative world, was only a form of latent power, to be transformed into real, military power:

States have two kinds of power: latent power and military power. These two forms of power are closely related but not synonymous, because they are derived from different kinds of assets. Latent power refers to the socio-economic ingredients that go into building military power; it is largely based on a state's wealth and the overall size of its population. Great powers need money, technology, and personnel to build military forces and to fight wars, and a state's latent power refers to the raw potential it can draw on when competing with rival states (Mearsheimer: 2001 p.153).

For Mearsheimer, "[w]ealth is important because a state cannot build a powerful military if it does not have the money and technology to equip, train, and continually 
modernize its fighting forces" (2001 p.165), a rationale that terribly legitimates the pursuit and the creation of conflict as arguments to keep a military-industrial complex running. Mearsheimer calls this rationale offensive realism, a strategy of States to survive in a world devoid of any agency that protects them. Neorealism, thus, acknowledges the liberalcapitalist dynamics in the world, but refuses to give in to the fantasy of cooperation and particularly the one of interdependence, as wealth generated by it is just raw-material for military security. Interdependence is just another word for competition and relative gains.

It feels hard not to react to such a cynical perspective on the world, which Mearsheimer calls a tragedy: "The sad fact is that international politics has always been a ruthless and dangerous business, and it is likely to remain that way" (2001: p.37), an echo of the reality Mearsheimer saw first-hand in Vietnam and then came to see in US American politics. But engaging with such ideas from a perspective of unconditional love requires acknowledging human potential for violence such as the one Mearsheimer came to experience. Having said that, it also allows a critique of the deleterious effects and kind of politics of violence that he reifies through his theorizing and highlighting.

Still, the most common response to either liberal and (neo)realist interpretations is a rejection of the negative potential human beings have. This rejection either takes place as a denial of its existence or the need to medicate and extirpate it. At this point, it becomes impossible to overlook the other side of the political divide, that is the influence of Marxism in International Relations Critical Theory, as the response to the world envisaged by liberals.

\section{3- Marxism in International Relations:}

Liberalism paved the way for the influence of political economy (PE) into IR - not only through classics such as Smith and Ricardo but also through Kant. In the same fashion, 
their critics of liberalism followed the very same path of bringing PE to IR, but through the ideas of Marx and Lenin. Liberalism added an extra dimension to the international state system that realist or idealist accounts overlooked - that is the influence of trade and business into inter-state politics (which enfeebled the state-system but did not question its relevance).

Meanwhile, the traditional Marxist assumption questioned the very centrality of a state-system as the ontological basis of the world, presenting the notion of historical materialism and class-struggle as its core and the State serving only to legitimate this struggle. These notions of historical materialism and class struggle contended that the current world system came to be through a historical process of exploitation of the proletariat by the bourgeoisie (and was bound to change through the revolution of the proletariat overcoming capitalism). This exploitation was made possible through the alienation of the proletariat on the role capitalism had in the formation of structures of bourgeois domination such as the State. Marx considered that classes were the real divide of the world, and the States represented merely local forms of class domination. Thus, Marx advocated for the International Workingmen's Association, as a means for proletariats from different countries to unite against their global oppression and overthrow the State as a bourgeois apparatus for domination.

However, because the State had never been a central preoccupation of Marx, his thought had originally been overlooked by traditional IR theorists, as it did not fit the International Relations Debates inasmuch as the State rested as the central assumption. It was Vladimir Lenin, then, who articulated Marx's philosophy for the international domain by juxtaposing comparing domestic class dynamics with inter-state dynamics in the international domain. In Imperialism: The Highest Stage of Capitalism, first published in 1917, Lenin denounced that World War I was a war of capitalist-imperialist countries 
fighting to establish themselves as major powers in order to control resources through colonial domination, and not so much as a strategy to survive as in Realism:

It is proved in the pamphlet that the war of 1914-18 was imperialist (that is, an annexationist, predatory, war of plunder) on the part of both sides; it was a war for the division of the world, for the partition and repartition of colonies, and spheres of influence of finance capital, etc. Proof of what was the true social, or rather, the true class character of the war is naturally to be found, not in the diplomatic history of the war, but in an analysis of the objective position of the ruling classes in all the belligerent countries (Lenin: 1999 p.27)

For Lenin, the "parasitic relations" that imperialist countries posed onto colonies and thus onto workers globally - through banks and business in competition for concentration of production and monopoly, denounced how domestic control was internationalized and the State opportunistically instrumentalized. He considered that this opportunism would be irreconcilable with any form of peace - whether or not wars had finished.

The Marxist heritage in International Relations led to two related interpretations of world politics, both pointing to the asymmetries of the international realm with political economy as the central aspect of IR: Dependency Theory and World Systems Theory. Due to their focus on Development, they will be discussed in detail in chapter 4 of this thesis.

Still, from a perspective of love, some considerations should be made so far. Marxism addressed one of the most basic human necessities according to Maslow's hierarchy of needs (which does not have to be understood in a structural manner): provision of food for living, through work/employment and payment for labour. In a Marxist-Leninist approach, the misery of people/countries resided in a capitalist system in which the accumulation of wealth by a bourgeois minority was possible through the exploitation of those poor people/countries. Out of this narrative of historical abuse, if I am, or my 
country's government is driven by those unmet needs, it is likely we will find a very strong case to desire the transformation of our current situation through the demise of the Capitalist world system and its bourgeoisie. It is at this point that Marxism becomes a loaded concept. In order to detect culprits for human misery, Marxism leans on villainizing and targeting whoever comes to represent the abusing bourgeoisie, an action that often justifies violence and places conflict within those people/countries as conflict-generative beings. If I approach this issue through an expectation to correct the misery I or my countrymen suffer, and if I read as abuse by bourgeois others, and in my very action I reduce their humanity by framing them as egoistic, self-centered and careless beings/countries, it is unlikely that any of us will manage to touch on our common humanity as to engage in meeting people's needs in a collective fashion, engaging all parties in the dysfunctional system. It is a matter of remaining locked in the abuse instead of envisioning an engaged liberation.

Now it remains a completely different question whether one is able to state their fragility, vulnerability and unmet needs and appeal to common humanity, wielding the respectful attitude necessary to engage even with people we perceive as abusers, as to address one's unmet human needs and actually encounter people. Due to large scale human suffering, however, the substitution of this more demanding and complex approach of touching people's hearts with Marxism's simplistic formula remains an easy strategy. It is important to highlight, nonetheless, that this complexity in no way becomes a reason for lethargy, inaction or indifference in the face of human suffering. In fact, the heart knows that there is no suffering that is foreign to itself; furthermore, a compassionate heart does not shy away from engaging in the transformation of suffering from a place of unconditional love. This love does not confuse or blame individuals and collectives with the misery I experience but sees in the people who suffer complete beings and groups 
involved in problems that need to be addressed and conflicts which can be transformed collectively.

\section{6- Critical International Relations Theory:}

Due to the strict focus on economics of traditional Marxist-Leninist interpretations (including its Dependentista and World Systems streams), a few scholars have made an effort to bring Marxist thought closer to the (original) political realm of IR by translating Marxism into more elaborated political matters. The roots of these critical IR authors reside mostly in the tradition established at the Institute for Social Research at the University of Frankfurt - also known as the Frankfurt School.

Walter Benjamin was one of the best-known representatives of the Frankfurt School. In his short essay Theses on the Philosophy of History (Benjamin: 1968), in analogy with a chess game being manipulated by a hidden chess master, Benjamin demonstrates his suspicion that Marx's historical materialism (the chess game), could not provide a meaningful explanation to a far more complex phenomenon which is social life. His point was that it was not enough to understand the rules of the chess game being played, the point was to understand the more sophisticated ways in which domination would takes place, how the very social setting of the chess game in question (a set in which a cheat structure favors one part) is determined, If I am to change reality. In this sense, only knowing chess rules - or the dynamics of materialism -perpetuates my domination if I am to be the loser of this conditioned situation. I also need to understand that the focus on these rules alone keep the domination mechanism running by consequence. Therefore, for the critical theorists, knowledge is never neutral and, as a part of social life, requires the scrutiny of its political dimension for its transformation. Particularly if I am predetermined to lose the 
social chess game, it is fundamental that I become aware of the conditions that lead me to lose and thus fight them.

For critical theorists, emancipation could take place only by becoming critical of both the rules of the game and the setting of the game that makes me end up and feel as a loser. It is simply not enough to understand the dynamics of oppression in place but also the source of this dynamics in order to find redemption. With such suspicion of how knowledge is produced and determined the terms of the debate, Critical Theory paved its way in IR by putting into question the very sort of debate which took place up until the $80 \mathrm{~s}$ : that the debate between Liberalism and Realism or, more specifically, its Neoliberalist and Neorealist strands, did not lead to a transformation of oppression but only managed it, a form of instrumental rationality.

Robert Cox became one of the first to articulate Critical theory within International Relations, for which he draws immense value from his life experience:

I grew up in Canada, and early on I realized that Canada is not just a single entity, but is also an assemblage of communities. I had to come to terms quite early with the fact that states, the homogeneous entities that form the point of departure for thinking about international politics, are in fact made up of combinations of ethnic/religious and social forces, which more often than not have conflicting interests and aspirations. After that, based in Switzerland for 25 years, I traveled the world while working for the International Labor Organization (ILO). At that time, I was no longer identified primarily as a Canadian but rather as an international civil servant - not as a cosmopolitan in the sense of having overcome local identification, but rather could I identify with many different peoples in distinct places. From this experience, I came to understand that all these different peoples ought to be respected in their differences. I thoroughly rejected the idea that the aim should be that everyone would ultimately be the same: difference is healthy, it is interesting, and it would be awfully boring if everyone were the same. So I discovered that not only Canada, but the rest of the world too, was made up of different and conflicting social and political forces, which functioned in alliances that crossed state borders. I saw shared interests with similar groups across borders as well as solidarities within states (Cox in Schouten: 2009) 
If Benjamin criticized the materialist chess game as a poor explanatory tool for all social life, Robert Cox criticized traditional IR theory as a tool unfit for defining the international dynamics not only because it overlooked a materialist chess game (as realists and neorealists did), but also that there existed several games at once (the case for the complex dynamics of exclusion that liberalists did not regard). On top of that, he considered that any static assumption of IR's units of analysis (that such games would never change) was problematic because things naturally change over time, just like the State has never been an ever existing aspect of it.

Cox considered that "theory is always for someone and for some purpose. All theories [and, thus, theorists] have a perspective. Perspectives derive from a position in time and space, specifically social and political time and space" (Cox: 1981, p.128). In this vein, he criticized Realism not only as ahistorical, but also as unchanging and conservative, because it sought to systematize the international dynamics of states by naturalizing them in their power politics (Cox: 1981). As such Realism sought only to identify the problems of the international domain and address them. Thus, Cox considered Realism to be a problem-solving theory. But it was also necessary to "stand apart from the prevailing order of the world and ask how that order came about (...) [be concerned] with their origins and how and whether they might be in the process of change" (Cox: 1981, p. 129).

In this manner Cox sought to devise a possible transformation of both the international order and of knowledge on it through the ever-changing dynamics between material capabilities, ideas and institutions, as forces that either promoted status-quo or brought about changes. He uses this as a model to discuss the interplay between social forces, forms of State and world order come about. Those are useful in "drawing attention to factors which could incline an emerging world order in one direction or another. The social forces generated by changing production processes are the starting point for thinking 
about possible futures" (Cox: 1981, p. 149). The reflection laid out by Cox remains faithful to a complex analysis of global transformations, and his concern over cultural difference amounts to a fundamental aspect of compassion and trust in collective capacity for peace and dialogue.

In a different approach, Andrew Linklater, another name associated with Critical Theory within International Relations, concentrates his efforts in bringing to question a moral dimension to IR. Linklater means to address the

issue of how the future of global society can be determined by freely chosen moral principles which further the autonomy of all human beings rather than by considerations of national power or by a concern for maintaining order and stability between the most powerful or potentially disruptive sovereign states (Linklater: 1998, p.22)

Linklater backs the idea that there are moments in which we engage with others that instill in each of us a form of sensibility towards alterity that calls for the exploration of universal principles to follow. After all, prior to being citizens of a nation-state in opposition to another we are men (sic) and we hold an imperative to relate to each other according to received moral standards. In a way, this is a manifestation of concern and care over fellow humans, but which is hampered by political obligations to Nation-States - as expressed in Men and Citizens in the Theory of International Relations (1990). Thus, Linklater considers that the emancipatory project laid out by Kant and inherited by Marx and the Critical Theorists, is severely obstructed by the Nation-State and those theories that sustain it, particularly Realism.

The problem is that the defense - in the line of Kant - of universal forms of morality beyond the State cannot be detached from a disregard over the contextual dimensions in which different cultural perspectives flourish, and run the risk of a continuous enlargement and reproduction of this moral system, which could not be farther from a compassionate and appreciative gaze towards difference. Linklater is aware of this tension:

A political theory acquainted with the problem of men and citizens should proceed to 
construct a vision of an integrated social and political life within a theory of the international system. On the other hand, a theory of international relations which overlooks the fact that modern citizens possess concepts of humanity fails by offering only a mechanistic interpretation of the states-system. (...) if it is true that the need for philosophy arises when the unifying power has disappeared from the life of man, then that fragmented moral experience specific to the modern state-system provides the issues with which the political theory of international relations must begin. (Linklater: 1990 p.36-37)

But another problem arises when such political theory aims at providing a moral system to address what is perceived as suffering (which again is bound to cultural perspectives). The problem is that this system sacrifices the inner and creative human potential of realizing compassion in order to accommodate a safe public, albeit non codified, morality system of conduct to be adopted. This amounts to a disciplinarization of goodness which is neither autonomous nor spontaneous - it is thus not an affirmation of love but an imperative to act lovingly. It might not be mechanistically reproduced, but it is presented as the sole choice to be made. I am forced into it if I do not intend to become a deviant. There is a subtle, but fundamental difference between realizing myself in connection/communion with others and realizing myself tied to others. Both represent encounter, but the former celebrates it, while the latter resents it.

\section{7- Post-Positivist International Relations Theory:}

Out of the critical stance on the benefits and problems of an international system based on nation-states and the dominant theoretical perspectives laid out by critical theorists, another grouping of intellectuals started taking shape, concentrating around possible alternatives to order. These theorists departed from the idea that international system is not only made by the states themselves but reinforced by the very academic discourses and reflections about them. 
R.B.J. Walker (1999) for instance accuses Linklater of remaining entangled in the problems posed by the development of a modern international state-system. Walker understands that it is the account of the modern international state-system that establishes the dilemma between being a human or a citizen, or the dilemma between the presence of a state that exerts power over citizens and whether the ethics of these citizens are circumscribed only within this state or go beyond it. Walker considered that getting lost in such antagonisms was to address the symptoms of a problem instead of the problem itself.

For Walker, to talk about International Relations is to define what counts as valid questions to be answered by IR, and this has the effect of producing and reinforcing a realm of reality to the exclusion of multiple competing narratives (Bigo \& Walker: 2007). It is only in the particular contexts in which human imperatives arise that a conflation of multiple perspectives can arise: in the not so much hypothetical situation in which there is a person drowning near the coast of my country, to those who are present it is not a matter of whether such a person is a legal citizen of that country in order to be rescued. Life has precedence over these matters and it needs not to be subjected to a third person's perspective on whether the drowning person has a visa, or may hold the status of a refugee, etc. The ethical call to action subverts the epistemological international debate over which assumption is the accurate one: conceiving the world in Realist, Idealist or in any other ways. In such a situation, both the state "remains" as an existing narrative - regardless of its implications, and is also overcome precisely by the citizens disregarding its rules.

For Walker, the pervasive discussion of IR on borders, inside and outside of a sovereign state, ${ }^{12}$ and even anarchy all reinforce a certain kind of discourse and establish regimes of power which affect life but which need to be nonetheless subverted and questioned. In this light, his post-positivist interpretation of IR denounces how mere

${ }^{12}$ See Walker: 1993. 
interpretations of reality, by the power of their reproduction and repetition, tend to establish themselves as truths, arguments significantly influenced by Foucault and poststructuralism.

In a similar vein, Richard Ashley, in Untying the Sovereign State (1988), asks how International Relations discourses work;

...how it gains significance in our culture, how it comes to be recognized as a powerful representation of a predicament so compelling and so self-evident (...) how, in the course of its development, this discourse has exposed its own rhetorical strategies (...) thereby opening up potentially productive avenues of inquiry hitherto closed off by it (Ashley: 1988 p.288)

The problem Ashley identifies is that discourses of IR, when crystalizing concepts such as anarchy and nation-states as foundational of IR, in fact turn into monologues in which those discourses are assimilated, becoming generalized interpretations and then becomes given facts (Ashley: 1988). For post-positivists, this part and parcel of the role which science came to occupy in human life in Modernity. In fact, IR as episteme is a mere reflection of science's place of authority: having earned legitimacy over competing perspectives on relations between different peoples and their communities in which anarchy and borders never had the weight they stressed.

These post-positivist perspectives, however, fall prey to their own critical gaze. Although they reveal that pretensely objective assumptions on the world are mere interpretations (which do hold power as they are (re)produced), the acid deconstruction of theoretical and intellectual perspectives have the effect of emptying discussions: from a perspective of love they also leave unattended and do not respond to a greater need of connecting from people behind those perspectives - that is, considering that communicating a perspective is reaching out to a public, to someone. If Realism is the claim of a world ridden with fear, or Idealism is mere escapism, or Marxism is a discourse on 
mechanistic injustice and hope, post-positivism represents rejection. Thus, a necessary step from an empathic and compassionate heart is to reaffirm an engagement and establish a connection or dialogue with the authors' ideas but fundamentally with the authors themselves in their humanness. This encompasses a much larger frame then questioning political intentions behind texts.

\section{8- Constructivism in International Relations Theory:}

While the post-positivist theorists in IR have considered international relations as narratives and discourses that in their repetition transmogrify into palpable reality, the critique and rejection of what they perceived as dominant discourses and the power they observed in those discourses, prevented them from proposing encounters to explore alternatives through the search for a common language and common topics. Instead, they focused more on subversion, dissidence and difference to grand narratives such as Realism. Ultimately, this resulted in an antagonistic demarcation of positions that hardly managed to transform conflicts of perspective, but only highlighted their existence and their nuisance. The friction generated, coupled with the critical gaze turned into one's own discourse created an environment of disillusion with new avenues for International Relations theory.

At the same time, a group of researchers came in with a less antagonistic, albeit no less critical, approach: Constructivist theorists approached IR with a somewhat solid inner trust that allowed them to realize that whatever the world came to be, it was nothing more than a process in which they had a saying and were a part of, directly affecting it just as much as they were affected by it. Those theorists conceived the international realm as a space constituted above all by the rules, norms, and the design of international institutions. 
Constructivism has become one of the most debated perspectives in IR since the $90 \mathrm{~s}$, and Nicholas Onuf and Friedrich Kratochwil are two of the main proponents of it.

In his book Rules, Norms, and Decisions - On the Conditions of Practical and Legal Reasoning in International Relations and Domestic Affairs of 1989, Kratochwil starts addressing the Realist premise that communities are different from individuals, and thus the Hobbesian assumption of Homo homini lupus need not to be projected onto the international level, after all the possibility of a real threat towards any given state or community by another is significantly smaller when there are so many individuals and institutions that might safeguard them from violence or war, thus community security is different from individual security. Kratochwil considers that "rules and norms influence choices through reasoning" (1991, p.11), and this reasoning is able to differentiate the situations in which customary rules and even norms might require a review or contain enough of a justification to be maintained as law. At the same time, Kratochwil is well aware that norms gain a certain force which might constrain change, particularly in a system that is not neutral. For him, norms can become more insidious than the assertion of power because they are a more impersonal constraint compared to menaces, but even in those situations in which norms are overbearing, validity-claims can be brought in and dialogue can give space to mutual understanding. As long as questioning remains an option, dialogue can become an orientation too.

Similarly to Kratochwil, Nicholas Onuf brings to the discussion of IR a constructivist perspective by approaching language as a particular form of making (creating) the international realm through the discussions carried out within the discipline of International Relations and, possibly, of unmaking the dominant discussion of IR following Wittgenstein's philosophical insights. Onuf's self-conscious task is to make something different and something out of a discipline that in his perspective never 
constituted itself as a proper discipline, for a lack of clear topic or foundation (Onuf: 2012 and Schouten: 2015).

Still, Onuf considers that whatever has been made of IR up to now - the dominant paradigms and their competitors - is a product of the dynamic relation between the world, those who interpret it, the ways these interpretations are communicated, and how convincing they are for an audience, which in turn end up perceiving not the world itself but the world through this convincing interpretation. With this, Onuf means to highlight the socially made content of all knowledge, IR's knowledge in particular, which in turn feeds theorists' dependence on this 'convenient convention'.

Onuf thus chooses to challenge this coherent sense of reality, breaking with the closed system in which IR's language itself sets the discussions made by IR theorists, and tries to introduce intentionality within the international debate, so as to yield new social "facts", which are relevant in his view. For instance, setting out multilateral institutions from the will to safeguard people's rights, which should dictate rules and practices of a different nature from institutions arising from the intention of hampering violence, and how they should ensue novel interpretations of the world.

Constructivism became a popular trend in IR theory particularly through Alexander Wendt's 1992 Anarchy Is What States Make Of It article, in which he attacks neorealists and neoliberalists for having too narrow of a focus on State's rationality. For Wendt, beyond realism's focus on self-help and security, and beyond neoliberalism's focus on maximizing benefits and minimizing costs, sovereign States are political communities (thus a plurality of individuals), which bear more or less stable identities and which are realized through the consolidation of their interests, which in turn can always change. Thus, any set of ideas powerful enough to come to be associated with national identity, interests and ensuing policies, may affect the dynamics between States, and eventually affect the 
international system. Thus, the way theorists inform and conform reality, which serve as basis for decision-makers to carry out their decisions, has profound implications for what comes to be the international domain.

If compared to either Kratochwil or Onuf who take from philosophy their approach to IR through debates on the role of language (and thus have a foot into post-positivism), Wendt can be regarded as a moderate constructivist for focusing on the socially constructed interest of sovereign states derived from their identity. Regardless of this schism within constructivism as a theoretical approach, which then again is a healthy indication of difference and plurality, constructivism has established itself as a major force within IR.

From a perspective of love, constructivism brings about a fundamental aspect of will, of agency when it comes to transforming one's perceived reality, via awareness and (con)formation of language or via the construction of intersubjective knowledge in the pursuit of interests, and this brings about a certain consciousness of interconnection. At this point, change becomes a concrete possibility, no matter how strenuous. At the same time, constructivism might give way for a certain form of stubbornness or might generate a certain conviction that one holds the power to address and change politics within their own means - a rather quixotic image. Whether those impacts are beneficial to the larger community can only be asserted from a contextual place and are not ready-given, as they can be skillfully hijacked or, at the very least, misinterpreted.

\section{9- Feminism in International Relations Theory:}

Through the discussion on International Relations carried out so far in this thesis, it comes with no surprise that there has not been a single female author representative of the theoretical traditions mentioned above. International Relations was and remains a discipline dominated by elite North-Atlantic white men, and it was only in the late 80 s that the field 
was challenged by feminist perspectives onto IR. When every other field within the human and social sciences was under female scrutiny since the 60 s, IR would not be able to remain indifferent to women's voices.

Cynthia Enloe, considered one of the first feminist contributors to IR, announced that paying serious attention to how women participate within the international domain exposed how much power it requires to maintain the international political system a maledominated domain (Enloe: 2000 p. 3). In her book Bananas, Beaches and Bases: Making Feminist Sense of International Politics first published in 1989, Enloe denounced that the entire conception of high politics, from its factual topics to its perspectives mapped "a landscape peopled only by men, mostly élite men", while "the real landscape of international politics is less exclusively male" (Enloe: 2000 p. 1), albeit women have been relegated to supporting roles. In her book, Enloe recollects many stances in which women remain a passive, invisible stock within (an enlarged conception of) international relations, from targeted consumers of transnationals, to servers for military bases and the tourist industries, showing the absence of women's voices on international matters.

As an oeuvre that opened mainstream IR to Feminism, Bananas, Beaches and Bases paved way for the consideration that paying serious attention to women's perspectives in international politics could completely change not only how international politics were conceived and carried out, but also how the discipline of IR was even conceived. The point to make was that no theory about the world can be separated from the author's own biography and their life experience in the world. Since IR is a biased field due to its domination by men, defining state behavior as a mirror of socially constructed notions of masculinity and how men relate to each other and think within a patriarchal system, feminists found relevant to highlight that IR's theoretical assumptions could not be separated by the socially constructed gender of the IR writers, and thus traditional IR was 
a dead end for feminists, and the discipline could use being reinvented anew. This was the point made by Ann Tickner in You Just Don't Understand: Troubled Engagements Between Feminists and IR Theorists (1997), in which Tickner highlights the problematic divide between the two groups mentioned in her title:

Feminists are arguing for moving beyond knowledge frameworks that construct international theory without attention to gender and for searching deeper to find ways in which gender hierarchies serve to reinforce socially constructed institutions and practices that perpetuate different and unequal role expectations, expectations that have contributed to fundamental inequalities between women and men in the world of international politics. Therefore, including gender as a central category of analysis transforms knowledge in ways that go beyond adding women; importantly, but frequently misunderstood, this means that women cannot be studied in isolation from men (Tickner: 1997 p. 621)

For Tickner, there are fundamental ontological and epistemological differences between traditional IR and the IR sought by feminists. She argues for the critical inclusion of those silenced perspectives Enloe highlighted, accounting for how their life experiences discuss and shape a different and pluralistic world ("the personal is political") from the one elite north-Atlantic white male IR scholars have debated. Such pluralism is noted particularly when one finds different feminist approaches such as Marxist Feminism, PostModern Feminism, and others. Situating one's knowledge and engage critically with all the pre-existing theoretical approaches becomes, thus an important matter, and efforts like this were carried out by Christine Sylvester particularly through Feminist Theory and International Relations in a Postmodern Era (1994) and Feminist International Relations: An Unfinished Journey (2002).

Still, a feminist approach to IR begs the question: how distinctive can feminism be when it comes to introducing the matter of love within IR? A feminist perspective offers fundamental insights for a perspective of love whenever it asks IR scholars to situate themselves within traditions and debates and also from their place of speech: that is, observing where I stand within my culture, the privileges I hold, whether I consider myself 
in a subaltern position, and cast a gaze into those historically silenced perspectives, in an open and tentatively democratic move. Most importantly, the situatedness of each thinker in relation to their research topic and to their contexts. That is one fundamental step into awareness of the dynamics at play in the context where one finds oneself and also an act of empathy.

However, as much as empathy is a fundamental aspect when it comes to connecting with others and thus part of experiencing love, the empathy of feminist perspectives alone need to be complemented with further steps. Remaining just empathic does not entail a full exploration of the transformative potential that love holds. To the contrary, when empathy allows one only to connect with the pain and violence others suffer, the diligent empathic feminist eye becomes trained and disciplined into combatting denouncing whatever is perceived as patriarchal violence. The problem lies in how channeling others pains into my own, if not done in a cautious manner, is the perfect recipe for blurring those who suffer this violence and thus not seeing them or trusting that they can be subjects of their own transformation/liberation - crystallizing people as permanent victims, while not addressing one's own pains. Crystallizing people as permanent victims implies that those who are lessened by patriarchy within IR can never actually gain prominence, and thus are always pitiful, miserable beings, something that is questionable particularly with the examples of acknowledged scholarship given by Enloe, Thickner, and other feminist IR scholars.

\section{0- Postcolonial International Relations Theory:}

In a similar way to Feminism in IR theory, postcolonial perspectives made their way into IR particularly through the academic exploration of the ideas around colonialism and its effects over and after the processes of independency in Africa and Asia during the second half of the XX century. The Bandung Conference of 1955 was held as a major 
representation of the efforts to politically think in national and independent manners for the recently independent states that composed part of it, along with the lesser known Solidarity Conference of the Peoples of Africa, Asia and Latin America held in Havana Cuba in 1966, which held an anti-imperialist tone and thus contributed to the non-aligned movement and Third-World perspective.

Postcolonial perspectives in IR were influenced by the political philosophy discussing discussed the infra-recognition of the humanity and agency of colonial subjects and the violence inbuilt within the creation of a world system through European colonialism. Seminal works such as The Wretched of the Earth by Frantz Fanon (1963), Orientalism by Edward Saïd (1979) and Gayatri Spivak's essay Can the Subaltern Speak? (Spivak in Nelson \& Grossberg: 1988), stand as the most common sources for postcolonial critiques, discussing respectively: how colonial domination - even without formal metropole-colony relations - is an abhorrent practice which fractures one's psyche through the broken-record discourse on people's inferiority and the corresponding inferiorizing practices; the pervasiveness of European ignorance in their gaze towards the East and how it blocks authentic knowing; and whether the voices and perspectives of the subaltern are taken into consideration when we are conditioned to seek familiar previously established intellectual, moral referents which speak on behalf of (inferiorized) others.

Yet, the body of Postcolonial literature has paved a timid way into IR - even though Fanon clearly discussed very relevant International politics in the XX century. This is also a surprising fact, taking in consideration the modern state system as a phenomena that cannot be dissociated from colonialism, making post/colonial discussions a rightful part of international relations. Such efforts of making explicit the relationship between colonialism and modernity can be traced to the project entitled modernity/coloniality, developed in Latin America mainly by Aníbal Quijano and Walter Mignolo, in an effort to think in "non 
European ways", as modernity in their conception is first and foremost a project that serves to make Europe the imperial center of their history, which has the "darker side" of subjugating other regions of the globe and their ways of living in conformity to an European project of a modern world conceived from the renaissance onwards (see Mignolo, 1995, 2011). Such lenses make explicit the violence of colonialism (shifting from political to cultural colonialism), racism, the expansion of the European rationality and, for the matters of IR, a socio-political organization into a state-system and the raking of (other) states in a hierarchical fashion that lead to the idea that poor and underdeveloped "third world countries" exist and that their citizens are second class citizens, inferior by nature (see Quijano, 2007).

In light of the above, Postcolonial and Decolonial theories, therefore, would aim at imagining a world outside of the invention of Europe and of the West as categories. This would mean that International Relations theory in itself is a European enterprise and should not be found in other contexts, which is not to say there are no correlates to IR in nonEuropean contexts. Therefore, the work edited by Amitav Acharya and Barry Buzan entitled Non-Western International Relations Theory-Perspectives on and beyond Asia (2010), thus comes to represent a laudable approach for IR if one is to gaze international theory through lenses that try to imagine International Relations carried out by countries elsewhere from Europe and the West, although not all perspectives in this book are necessarily post/de-colonial. Encompassing diverse perspectives from India to Japan, the book focuses on the perspectives of authors from different Asian countries, and how they provide answers to why their countries' way of conceiving international relations is much different from the European international politics "heritage" (sic). For instance, Chaesung Chun (Chun in Acharya \& Buzan: 2010) argues that there is no IR theory in South Korea because of the heavy influences of Western imperialism which suppressed the influences 
of Confucianism in the Sino-centric tributary (inter-national) system, which has led Korea to discuss IR through Anglo-American perspectives. Likewise, Navnita Behera, tapping on Spivak, argues that any Indian contribution to IR that does not envision a post-Western world is doomed to be a second-class Indian contribution to IR theory (Behera in Acharya \& Buzan: 2010). This would place Indian IR behind the Western IR theoretical production, which in turn has nothing to do with carrying out encompassing international relations policies, such as the one conducted by Nehru.

An empathic attention to the underlying aspects of the postcolonial discourse, reveals that such topics touch upon collective trauma and places of hurt people have experienced through the oppression of their ancestors, their peoples or even first-handedly, as poignantly argued by Fanon. The narratives of categorization into inferiority of nonEuropeans, and the dehumanization of "others" taking place during - and after - colonialism remain a powerful source of pain-anger-disgust energy that motivates decolonial critiques in order to correct European wrongness and the ensuing injustice, through seeking recognition of past wrongdoing, dismantling discourses that glorify the past, and actively stimulating authentic knowing and respect for others. This informs the denunciation of the Latin American writers from the Modernity/Coloniality project and relates to Said's critique-criticism of the Western gaze.

In their work, Buzan and Acharya's work intend to give voice to "non-Western" perspectives on IR theory, taking for granted West and non-West merely as geographical categorizations while discussing a very Western (culturally speaking) matter, and trying to theorize from an alternative place within IR, thus, within the West. And the question that needs to be asked is: When will present policy responding to the (colonial) past be enough, as to release us from trauma across times? How can an initiative that is not locked into permanently reacting to the past be incorporated? As an answer to this, Navnita Behera's 
perspective touches upon a central point: the importance of transforming IR in itself, through the discussion of practices related to non-alignment and difference (following Nehru's policies), but above all reimagining aspects that traditional IR theory silences (Behera in Acharya \& Buzan: 2010 p.100), which are fundamental to one's own life beyond the dwellings of the modern state, pointing to the poverty of IR in spite of all the creative forms of possible relating.

\section{1- Final Considerations on Love in International Relations:}

This chapter departed from the consideration that much has been written about international relations, having formed a proper theoretical body, but this might have been precisely the fault of IR as a discipline. In its effort to become a well established discipline within the social sciences, IR got lost in its commitment to grasp the causes of war and violence alone and never stepped outside of it. Little consideration was given to the criticism that was first expressed by Galtung, of thinking peace from peaceful terms. The international debate seemed to carry on aloof of this and has kept growing ever since.

Contemplating love as a fundamental aspect of (experiencing) peace, which has never been taken in consideration into IR theory, this chapter visited each theoretical strand of IR in order to elicit and render visible the perspectives of human relations that might inform those theories on inter-state affairs. From calling attention to how the objective and cognitive gaze of the international had implicit inter-subjective elements on human relations, I raised key points on the possible transformation of one's personal and subjective perspective, in the hopes that this could then also change their views on the international and how its epistemology is regarded.

- The central aspects of human relations I identify in each theoretical strand of IR are:

Within Idealism, the desire of forging a perfect society in order to devise 
mechanisms of conflict management directly associated with the rejection (and denial) of human proneness to violence; while within Realism, it is the very acceptance of our own darkness that leads to a resignation to see nothing but it. Behaviorism, following idealism's core aspect of understanding and managing human nature, empirically tries to determine noteworthy and consistent behaviors in an automatism that is overtly quantitative, ahistorical and unphilosophical, which leads to disconnection from concrete human life. Meanwhile, the English School focuses on the role of the law and of norms to balance realism and idealism, which stems from a pragmatic and utilitarian navigation of politics, and of people in the pursuit of self-interest.

- The Political Economy take in IR represents the influence of abstract economic assumptions in politics, which gave way to ideology governing (overlooking) human relations, with Marxism fighting abuse over the proletariat, and Neoliberalism fueling inequality. Neo-Realism, taking from the growing role of economics in world matters, advocates the use of economic as source for military forces to gain power and influence. It is the interpretation of Neorealism's approach as immoral that composes the main tenets of a Critical School of IR, influenced by the Marxist understandings within the philosophy of the Frankfurt School.

- Within the influence of philosophy, it is through the echoes of postmodernism that Post-Positivist theories within IR will pay attention to humans left out of power debates and the grand narrative of modern State-Centric accounts. In the meantime, Constructivism appears as a novel theoretical strand within IR Constructivism, focusing on the willpower to intervene and reshape order and yield "new" social facts that influence the international debate. In a similar way, both feminism and Post-Colonialism focus on highlighting and addressing the historical blindness 
towards the violence suffered and experience of those left out of power-politics: women, the queer, and the colonized.

Finally, it is important to make clear that the point of this chapter, however, is not to label each theoretical strand and thus their defenders, as even my interpretations are also personal and subject to difference and disagreement. Yet, the effort in this chapter was to demonstrate theory as entry-points to also particularly address those personal, inner states and raise awareness on how to sensibly approach both the personal intentions and inner states of individuals while coherently arguing one's theoretical point of views, amounting to a comprehensive approach to the study of peace, conflict and violence on the meta level and the more direct one between individuals. 


\section{Chapter 4 - Love and the Development Discourse:}

Represented as a civilizational improvement on the past and participation in a future of boundless consumption, development is normalized in modern discourse as seductive inevitability. But development is imagined and measured only on the positive side of the material ledger. However, it has revealed itself to be a paradox, betraying its initial promise. (Philip McMichael in Kothari et al: 2019, p.12)

\section{1- Introduction: $:^{13}$}

In the previous chapter I tried to make explicit the assumptions of human relations that permeate the epistemology of International Relations in its many theoretical strands. I explicitly unpack these approaches and how they correspond with a human engagement that is coherent with a perspective of peace studies that cannot be disconnected from love as a service to humanity. Likewise, in this chapter I visit some variations on the discourse of development and its critiques and elicit any assumptions of love and humanity within this discourse.

As it is, the discourse of development seems to have replaced reflections on what it means to promote or strive for a dignified and harmonious life, regardless of the many diverse ways in which a dignified and harmonious life can be interpreted. Although dignity and harmony are subject to cultural contexts and even one's own perception, the whole idea

13 This chapter is a revisited version of my M.A. Thesis presented in 2013 to the International Master in Peace, Conflict and Development at Universitat Jaume I. 
of development is based on a modernization project which emphasizes political-economy as a strategy to implement a certain life order.

Advocates of development argue that a dignified life is a life that is free from deprivation of the most basic needs. Without re-entering Maslow's pyramid of needs debate (see chapter 1), it is safe to say that at least the largest concern on the most basic physiological needs can be considered covered: We do live in a planet that produces enough food to feed everyone as states the Food and Agriculture Organization (Food And Agriculture Organization of the United Nations: 2012). Now it is an entirely different issue that there exist people who starve and who lack access to food and drinking water, and political apathy to such human suffering. In this regard, the debate around development being a necessity out of a lack of food and water is without a doubt a fallacy. Such an argument does not mean that those who are deprived of their most basic needs are to be ignored simply because the idea of development as intervention on those cases is misleading. The case of love as being of service to humanity is meant to gear communication and how people relate in order to promote a transformation of their struggles, and not to lecture and implement a one-size-fits-all lifestyle.

To talk about development is to talk about its complexity. One cannot analyze every development practice carried out by organizations throughout the world, simply because there are too many and most of them vary in their conceptions of development and activities. Also, since the purpose of this thesis is to promote a debate on an epistemological level of development as part of international studies, I focus on the theoretical and conceptual approaches of it. It is impossible to recount every diverse development initiatives that exists. However, I consider those development enterprises that do take shape based on a shared and overarching worldview, which is certainly open for questioning. 
With regards to worldviews, I start with my original one and its relation to development: The country I come from is considered one of the most unequal socioeconomic countries in the world. Although there have been significant improvements in addressing the gap between rich and poor in the last decade, in Brazil one can see a very exclusive skyscraper right next to a favela, and the difference still assaults my eyes every time. Having lived this reality since the 1980s, I was born under a context in which the fight against poverty and underdevelopment was already considerably strong. In fact, even nowadays this is a very powerful mentality in the whole region of Latin America: that poverty equals lack and misery, and thus the opposite of dignity. It strikes me how widespread the perception of Latin America as a poor, backward and still developing region. And, in the face of such abundance that allows for skyscrapers and lavish lifestyles to exist, is poverty really the case for development?

Out of this brief questioning, the plan for this chapter is to first identify the roots of development mentality and its variations, the post-development critiques, and some perspectives held as alternatives to development, considering whether they shape human relations out love and thus, whether they are to be brought into peace studies.

\section{2- Economic Development and its Roots:}

The concept of development is commonly traced back to 1949 when the United States of America's president Harry S. Truman announced his agenda for 'peace and freedom'. Truman believed that, by sharing the United States' scientific and industrial progress, it would lead underdeveloped countries to growth and improvement. The 
president understood that these were the key elements for bringing greater production and that this production would lead to prosperity and peace.

However, to talk about development in the first place requires a minimum understanding of what Truman associated with the idea of growth and improvement. These ideas were based mostly on the assumptions of classical economic thought, which dates back to Adam Smith and David Ricardo. Yet, slightly before those writers made their claims on what a liberal world should be like, medieval thought strongly connected economics with religion, which was then deemed the authority in terms of life and peace. The Catholic Church controlled economic activity upholding that paying obedience to God was of more importance than economic activity and that everything had a just price. In this sense economic activity and economical justice were a reflection of God's will (Peet \& Hartwick: 1999 p18). Suffering from deprivation, therefore, was a matter of God's punishment, regardless of how it impacted society.

With the Reformation, protestant thought and especially Calvinist thought shifted from the differentiation between paying obedience to God or dedicating oneself to economic activity. They considered both actions were connected and that one could praise God through his work and economical gains. Wealth, in this sense was not only a consequence of labour but a consequence of praising God through hard and diligent work. Accumulation, which for Catholics meant dedicating time more often to economics rather than worshipping God, became the tool of salvation for Protestants. This is the setting in which classical economics based its idea of labour, wealth and productivity (Peet \& Hartwick, 1999, p19), in other words, morality.

Adam Smith, in his book An Inquiry into the Nature and Causes of the Wealth of Nations of 1776 considers that economic growth was a matter of leading a thrifty life 
combined with an accumulation of capital. This would be the ultimate goal of one individual, materialized through his work. Smith also assumed that there would be no such thing as cooperation or benevolence in human relations. Everything was a matter of negotiation for economic gains. People offered things expecting something in return. The fact that some nations were prosperous was a matter of progressive specialization in producing goods and trading them with other nations, which specialized in other products. No instance should be necessary to regulate those tradings, because markets would selfregulate its prices. Since any economical actor who did not properly negotiate a good price would not be considered a good trader, this would force him to return to the ideal market price (Peet \& Hartwick: 1999).

David Ricardo was another thinker that could be considered one of the founding figures of political economy. Ricardo took on Malthus' fearsome declarations that the world was headed to a catastrophe because of the arithmetical growth of food production while population grew on a geometrical basis. Ricardo assumed that overpopulation could diminish the gains of economic growth. For him, although food production would expand because of population growth, it would eventually exceed the amount of fertile land available. This would make prices rise, because of the extra costs associated with production on less fertile areas. In any situation, the benefits of the economic growth would remain with the landowners.

Ricardo also gained prominence among the classic writers of economics because he advocated free trade just like Smith. Ricardo, on the theory of comparative advantages, considered that happiness could be increased when a country focused on producing a good in which it excelled in - for whichever reasons: climate, technology or other. This would allow a country to trade the surplus of its goods with the products produced by another 
country who excelled in an alternative product. This would benefit all (Peet \& Hartwick: 1999).

Both Adam Smith and David Ricardo are considered the godfathers of economics and founders of Liberalism. To talk about economics is to talk about a field of knowledge that deals with the matters of production and accumulation. Liberal thought argues for the freedom to pursue one's economics interests, and yet it cannot be dissociated from legitimizing greed. And it is not the case to condemn greed as a capital sin in a moral frame, but to realize that from a perspective of love for others there is no need for one to accumulate capital out of fear. Love comes from a place of abundance, and holding enough to share, of being genuinely generous. And if generosity and care for other's livelihoods are considered, liberal theories fall apart.

Yet this was not quite the intellectual reaction that liberalism faced. The biggest contender of liberalism, John Maynard-Keynes was not so sure of the liberal assumption that a market could regulate itself on its own as to provide wealth and economic growth for a generalized greed. Writing in the beginnings of the XX Century, he was very influenced by the context of the Great Depression, which led him to review the liberal assumptions that for him provoked the crisis: the lack of investment, employment, and consumption to increase income. Keynes considered that investment could raise income, and income could lead to employment and consumption, spinning the economy. However, Keynes noticed investment from the part of entrepreneurs could be delayed, postponed or simply not happen if such entrepreneur chose so. In a way, Keynes' argument could be expressed as a concern against greed as retaining one's capital.

And the strategy Keynes devised was to guarantee that the economy mechanistically kept running by introducing a public investor replacing capitalists from addressing their 
greed and making investments. Keynes considered that the government had to play a role as an investor that could lead to and assure more employment, which meant more ways of consuming. Keynes understood that unemployment meant economic stagnation, so investment and spending were central for keeping the economy running. The State as a steward of the economy promoting expenditure was the biggest clash on the thrifty philosophy of Smith. With that, Keynes contribution to economics went through World War II and beyond, for employment became important enough to figure into the United Nations Charter. Keynes approach was perceived to be the best policy for developing countries to adopt, since it would grant control over one country's economic direction. In the context of the great depression, it is not surprising that US president Roosevelt adopted and popularized such a policy. Promoting the state as the steward of economics was an important step to benevolently manage people's lives, promoting full employment and caring about income and consumption. And yet this is called into question when economic growth and employment become associated with developing a weapons industry, dramatically exposed during and after World War II. Besides, one is not to assume Keynes was concerned much with human welfare, but with State-control of the economy by élites, an English Lord as he was.

\section{3- Development and International Political Economy:}

\section{1- Development and Keynesian Institutionalism/Paternalism:}

Post the Great Depression and the devastation of World War II, there was a great opportunity for the establishment of Keynes' paternalistic approach to economics and an international monetary system that would guarantee and regulate the economic flow in between countries. For this purpose, Keynes would eventually start collaborating with 
Harry Dexter White, chief international economist at the US' Treasury Department. This Anglo-American collaboration, in the words of Morgenthau an "agreement of the experts on principles for international monetary cooperation (...) in harmony with the best traditions of democracy" (Department of State of the United States: 1944 p.1629) was circulated to the Allied Countries during the United Nations Monetary and Financial Conference, also known as the Bretton Woods Summit in 1944. Over this summit, a series of institutions were proposed such as the International Monetary Fund (IMF), the World Bank (WB) and the General Agreement on Trades and Tariffs (GATT), leading to a new global economic agenda, aimed at global economic growth.

Under the expansion of an international monetary system fostering economic growth - and the growing concern of expanding the US' area of influence in order to contain the spread of Communism, president Truman of the United States, delivered an unsurprising speech on January 20th, 1949, founding the concept of development:

I believe that we should make available to peace-loving peoples the benefits of our store of technical knowledge in order to help them realize their aspirations for a better life. And, in cooperation with other nations, we should foster capital investment in areas needing development .Our aim should be to help the free peoples of the world, through their own efforts, to produce more food, more clothing, more materials for housing, and more mechanical power to lighten their burdens. (...) With the cooperation of business, private capital, agriculture, and labor in this country, this program can greatly increase the industrial activity in other nations and can raise substantially their standards of living. Such new economic developments must be devised and controlled to the benefit of the peoples of the areas in which they are established. Guarantees to the investor must be balanced by guarantees in the interest of the people whose resources and whose labor go into these developments. (...) Experience shows that our commerce with other countries expands as they progress industrially and economically. Greater production is the key to prosperity and peace. (The American Presidency Project: 1999) 
During the following decades of 1950 and 1960, Modernization or Growth Theory became a strong theoretical support for Truman's views. According to Sardar, "Modernization was defined as the process by which a society comes to be characterized by a belief in the rational and scientific control of man's physical and social environment and the application of technology to that end" (Sardar: 1999, p.52). Moreover, Modernization Theory became a tool for contentionregarding the influence of the USSR on many countries during the Cold War. It implied that certain western values had universal validity and should be applied everywhere, firmly believing that unlimited growth was possible, and that the stage of backwardness of some countries could be left behind, at the price of westernizing their culture and joining the global market. Meanwhile, "growth theory was the theoretical foundation for intervention in the development of poor countries in a kind of global keynesianism" (Peet \& Hartwick: 1999, p.41). Its philosophy was understood as an imperative for the "Third World" countries which underwent the process of decolonization.

Behind the Keynesian and Modernization logics, (economic) life was to be subjected to the scrutiny and correction of those who knew better how to grow appropriately, according to their creed. In this sense, life is not recognized as the human capability for autonomous creativity on sustenance and well-being, but rather as fulfilling other's economic expectations, which is quite different than finding an organized support for the exploration of human potential for creation.

\section{2- Development and the Liberal Reaction:}

Two decades after a diligent Keynesian policy, during the oil crises of 1973 and 1979 and the establishment of conservative governments of Margaret Thatcher in the 
United Kingdom and Ronald Reagan in the United States, the voice of a few critics of global keynesianism started echoing. According to Peet and Hartwick, three elements helped neoliberal politics take shape at the beginning of the 1980s: (1) Milton Friedman's Monetarism and the Chicago School of economics argument that governmental expenses generated inflation and indebtedness; (2) Friedrich von Hayek's reintroduction of Smith's and Ricardo's classic assumptions; and (3) a rugged individualism and glorification of laissez-faire under the context of crisis (Peet \& Hartwick: 1999, p.49). Neoliberalists opposed the perceived interventionist nature of the Keynesian state and claimed freedom instead, but freedom turned out to be in fact a disguise for egoism, instead of respect and support for one's individual choices.

Neoliberals advocated the reduction of government participation in the markets, which would allow companies to reap benefits that would eventually and progressively trickle down to society as free trade was implemented. Such a view was yielded with enthusiasm when the Newly Industrialized Countries (NICs) started demonstrating incredible growth rates. It is important to notice that Modernization/Growth Theories broke with Keynesian economics, but only when it came to the path towards the understanding of progress. Instead of taking the Keynesian model of progress, they chose the liberal model of it. The goal of progress was still the same. In any event, among the countries that showed high growth rates was my very own: Brazil. However, the gap between rich and poor continually seemed to grow and the trickling down of economic benefits were not realized.

Before the beginning of the 1990s, the economist John Williamson from the International Institute of Economy published a book putting together the set of economic prescriptions relating to the policies being implemented by the International Monetary Fund, the World Bank and the government of the USA with a strong market orientation. These policies were known as the Washington Consensus. Such consensus aimed at the 
liberalization of economies through a series of recommendations such as: fiscal discipline, limited public expenditure, tax reduction, interest rates controlled by the flow of the market, liberalization of trade, abolishing barriers to foreign investment, privatization and deregulation (Peet \& Hartwick: 1999, p.52). Countries undertaking aid and/or consultancy from the Bretton Woods institutions imposed those policies as conditionalities, restructuring their economies.

\section{4- Development in the perspective of Dependency and Systems Theory:}

The Structural Adjustment Policies (SAPs) from the Bretton Woods institutions predicating the Washington Consensus had a strong impact on the developing world. Asa Cristina Laurell contends that with the conditionalities of SAPs

national governments have renounced the instruments that are necessary to direct the national economic process and to protect production and employment. Simultaneously, their international bargaining capacity has been weakened. Liberalization and dependency on foreign capital in order to equalize the balance of payments have made economies (...) highly vulnerable to financial speculation and external shocks. (...) The vulnerable and unstable economic growth has taken place primarily in the modern export sector that [occupy] little labor and is dominated by multinational corporations. Thus, the measures taken to constitute a new pattern of accumulation have not only sacrificed the national general interest but have also provoked an unstable and inequitable growth with a dramatic social impact (Laurell: 2000, p.307-308).

This of course made developmental practices even more urgent, leading the 80 s to be commonly referred to as the "lost decade". In a development mindset, this would make remediating the poor and marginalized a much-needed work, at least until they were able to join the benefits of the global market. But in Latin America, Dependency Theorists were suspecting the limitations of such policies since the early 1950s. Coming from the most prominent educational institutions in their own countries, these intellectuals who had 
contact with economists worldwide, saw the contradictions of Capitalism and the situation of the economies in their countries. Comparing them to the development of Europe or North America, they naturally worried about their less fortunate compatriots. Among the most prominent theorists were Raul Prebisch, former head of the Central Bank in Argentina, Theotonio dos Santos and Celso Furtado, both Brazilian economists. Dos Santos indeed offers a concise explanation of their critique:

Dependence is a conditioning situation in which the economies of one group of countries are conditioned by the development and expansion of others. A relationship of interdependence between two or more economies or between such economies and the world trading systems becomes a dependent relationship when some countries can expand only as a reflection of the expansion of the dominant countries, which may have positive or negative effects on their immediate development (Dos Santos: 1970, p.231)

Dependency Theory believed that the international system was not homogenous but could rather be read as a core-periphery relation in which trade in the international market accentuated inequality and the asymmetry between rich and poor and developed and developing countries, rather than overall growth. Such assumptions were rooted in Marxist interpretations of class struggle transplanted onto the international system. However, in Latin America, during the context in which such Marxist voices rose, the political momentum did not seem to favor their echoing. It is important to remember that Latin America was part of the United States' area of influence and their governments were strongly supported by the US to contain the spread of communism. Most of the countries in the region had military governments who proved very hostile to such leftist influences. The political suffocation took violent forms especially in Chile and Argentina.

Somewhat similar to Dependency Theory, another theory that had great influence for development was World Systems Theory, as proposed by Immanuel Wallerstein in the 1970s. Being raised in a very politically conscious family, Wallerstein demonstrated 
interest in the political field and how it related to world affairs from a very early age, especially for having lived during the World Wars and afterwards during the development age. His early academic endeavors, which focused mainly in Africa (International Sociological Association: n.d.) played a significant role in his sensitiveness towards the peripheries. Wallerstein believed that with phenomena such as the globalization, all the concurrent mini-systems progressively became one world system marked by the Capitalist world economy. That meant that power was no longer held politically although could manifest in such a way. Power was held by those who detained means of production, who in turn could make the state assure their capital accumulation (Wallerstein: 1979). Wallerstein shifted Dependency Theory's binary worldview of core and periphery to a tripartite world composed of center, semi-periphery and periphery. The decurrent relations between those parts were to assure maintenance of the core's benefits. From this understanding, the approach to development available under such a Capitalist world system circumstance was a conformist one, in which through various processes the periphery should at best be brought closer to the semi-periphery.

The problem with the Dependency and World System's approach is that such analysis does good service mostly to ones feelings of resignation: in terms of dependency, the analysis took place in an unfortunate political moment with a sharp difference in power between governments and intelligentsia; in terms of world-systems, the complexity of meaningful intervention and the probability that only small changes would be possible would require a great deal of determination and a strong motivation. 


\section{5- Social and Rural Development:}

It is from this extensive and (maybe not so much) diverse views and intellectual approaches that many development initiatives started taking shape and being operationalized, according to several different identifiable needs. This means that development in practice took on different focuses. The variety of identifiable focuses led to the use of several adjectives combined to the word development. Nowadays, one can find a multitude of different terms and approaches, and some of the most famous are: Sustainable Development, Social Development, Rural Development and, the most recent and "successful" take is Human Development, an idea that became central in international development since its inception in 1990.

As James Midgley points out, Social Development is "an approach for promoting human welfare(...) [whose] most distinctive feature is its attempt to harmonize social policies with measures designed to promote economic development” (Midgley: 1995 p.1). Midgley calls attention to the fact that the adoption of economic prescriptions led to impressive results both in the Western industrial countries and some developing countries of the Third World, bringing improvements in social welfare. However, in some parts, this economic development was not accompanied by an attendant degree of social progress, calling for the integration of both the economic and social domains (Midgley: 1995 pp. 24).

Midgley elaborates on the difficulties of defining/describing what does social welfare and progress mean, suggesting that "the degree to which social problems are managed, (...) the extent to which needs are met and, (...) the degree to which opportunities to advancement are provided" (p.13-14) and how some indicators such as employment, school enrollment, crime rates or institutionalized indexes might be of help to measure 
social development. In this logic, some ways to promote social welfare would be through governmental social services (social administration), social philanthropy and social work. Midgley traces the origins of social development to a colonial period when indigenous political leaders in the colonies strove for better social conditions. Along with that "missionary organizations or charities created by settlers or educated local people" (p.53). Its popularization, however, would become possible with the creation of the United Nations.

The problem is that most of the time these social development projects are biased. Many times, developmental projects are directed towards the poverty that is seen, which affects our retinas in our daily life in urban centers and small towns nearby. There is an assumption of poverty as suffering, but a suffering which is irrelevant until it befalls under the gaze of development. In Rural Development: Putting the Last First, Robert Chambers (1983) draws our attention to the unseen poverty in the rural areas where neither paved nor rail roads arrive, where access is difficult, and time spent there can be unpleasant for those sent by various developmental agencies to check on certain life conditions. In Chambers' own words: "development follows main roads" (p.13). He questions what lies beyond that and notes that many resources are spent on cases where there already is infrastructure, projects well settled and research conditions. But the faces of poverty in the depths of the countryside are of malnutrition, difficulties in food production, infections and degrading conditions.

As Lalnilawma, an Indonesian scholar advocating for the development projects carried out by NGOs stated,

[R]ural development has emerged as a strategy designed to improve the economic, social, and cultural life of a specific group of people living in rural areas. It aims at increased employment, higher productivity, higher income as well as minimum acceptable levels of 
food, clothing, shelter, education, health and building up of a sound value system which is in keeping with the high cultural heritage of the country. (...) Rural development must constitute a major part of development strategy if a larger segment of those in greatest need is to benefit (Lalnilawma, 2009, p.50).

But no matter how well intentioned the concerns for good living are, development projects instead of generating autonomy for peasants, integrate them into the world economy as rural workers of agribusiness, which take place in many areas close to the main roads, truly international businesses exportation corridors - an important feature in Structural Adjustment Policies. In Latin America, the face of the rural area changed from isolated lands which previously belonged to small peasants working for self-sustenance, to fields devoted to commodity export by multinational corporations, which for the concern of rural development advocates, never lead to a final stage of development but pushed poverty and peasantry even further away. In response to that, the term New Rurality started being used in academic circles without a clear definition, but seemed to mean a broader use of rural areas beyond only farming and subsistence agriculture (Kay, 2008).

\section{6- Globalism, Sustainable and Human Development:}

Eventually, human impact over nature became an international concern which would lead to the United Nations Conference on the Human Environment 1972 in Stockholm, Sweden. The purpose of the conference was to "exert common efforts for the preservation and improvement of the human environment, for the benefit of all the people and for their posterity" (United Nations: 1973), which would later on be followed by the Rio 92 conference, where the Agenda 21, an international sustainable development action plan for the XXI century was designed, without enforcement power.

During the Stockholm meeting, the conservationists' worries were met with resistance from 
those countries still pursuing industrial development and economic growth as a way out of poverty. This impasse led the political and diplomatic negotiations to think of a hybrid term that would encompass both the perceived need for development in the south and the pressures for sustainability. Such pressures for sustainability partially derive from the studies of Donella and Dennis Meadows which were titled The Limits to Growth, also published in 1972 a few months prior to The United Nations Environment Program Meeting. ${ }^{14}$

Eleven years after the Stockholm Conference, the preoccupation with the environment and the quest for development would lead to the creation of the World Commission on Environment and Development in 1983. The commission came to be known as the Brundtland Commission, named after the leadership of former Norwegian Prime Minister Gro Brundtland, and their final report became famous under the catchy title of Our Common Future. The report founded the concept of sustainable development as "development that meets the needs of the present without compromising the ability of future generations to meet their own needs". ${ }^{15}$ Among others, the goals of the report were:

- to propose long-term environmental strategies for achieving sustainable development by the year 2000 and beyond;

- to recommend ways concern for the environment may be translated into greater cooperation among developing countries and between countries at different stages of economic and social development and lead to the achievement of common and mutually supportive objectives that take account of the interrelationships between people, resources, environment, and development;

- to consider ways and means by which the international community can deal more effectively with environment concerns; and

- to help define shared perceptions of long-term environmental issues and the appropriate efforts needed to deal successfully with the problems of protecting and enhancing the environment, a long-term agenda for action during the coming decades, and aspirational goals for the world community (Brundtland: 1987, p.5)

\footnotetext{
${ }^{14}$ More information on The Limits to Growth in the Critique of Development part of this chapter.

${ }^{15}$ More information on The Limits to Growth in the Critique of Development part of this chapter.
} 
But the vagueness of such proposals and of sustainable development as a concept eventually led to the abuse of one-sided economical approaches, and the critical discussion of a new concept of development. Therefore, fixing the pitfalls of such a term brought up the need to conceive yet a different conception of development. In this light, Mahbub U1 Haq and Amartya Sen coined the concept of Human Development focusing on "people's real needs".

Sen's main tenet was to understand development as the enlargement of human capabilities for proper social functioning, as he retrieves, alongside Ul Haq, what they consider the primordial concern of the subject of economics: the lives of human beings rather than the production of commodities. Sen argues that the concept of Human Development is to be a rival to measures of Gross National Product (GDP) as a representation of people's well-being (Sen in Fukuda-Parr: 2004 p.X).

[T] he human development approach is about expanding the richness of human life, rather than simply the richness of the economy in which human beings live. It is an approach that is focused on (...) improving the lives people lead rather than assuming that economic growth will lead, automatically, to greater wellbeing for all. Income growth is seen as a means to development, rather than an end in itself (...)

is about giving people more freedom to live lives they value. In effect this means developing people's abilities and giving them a chance to use them. For example, (...) to live a long, healthy and creative life, to be knowledgeable, and to have access to resources needed for a decent standard of living

is, fundamentally, about more choice. It is about providing people with opportunities, not insisting that they make use of them. No one can guarantee human happiness, and the choices people make are their own concern. The process of development - human development - should at least create an environment for people, individually and collectively, to develop to their full potential and to have a reasonable chance of leading productive and creative lives that they value (United Nations Development Program: n.d.) 
However, Sen notes himself that Human Development, while integrating other variables to measure development - including economic growth, may itself reinforce this economicist understanding of well-being, only to introduce other aspects to measure life against it (Sen in Fukuda-Parr: 2005 p.X).

Meanwhile, Sen considered that Mahbub U1 Haq focused on the practical aspects that could work as "an improvement on - or at least as a helpful supplement to - GNP" (Sen in Fukuda-Parr: 2005 p.X). As a special advisor to the United Nations Development Program, Ul Haq proposed the concept of Human Development and introduced the Human Development Report and the Human Development Index as tools for informing the worldwide status of human development and measuring each country's development status.

Both Ul Haq and Sen deserve to have their concern for human life recognized. Having said that, Sen was accurate regarding his concerns that human development could reinforce measuring richness and wellbeing through GDP, despite an incomplete characterization of good life: much of the current critique on development and postdevelopment resides in people's desire to be fundamentally wealthier, wealth being the means to achieve and sustain other relevant aspects of life.

Moreover, there is a deeper issue with Human Development and its underpinning that human capabilities need to be enlarged beyond wealth: it still predetermines which aspects of people's life deserve to be addressed. Sen may coincide with Carl Rogers' humanistic approach in that human beings already hold all their capabilities for exploration in a latent form, and he may concur with inequality issues such as Paulo Freire did. But human development will nevertheless list a series of indicators of what a rich life could be, and thus fixes criteria in order to assess people's life. More than aiding individuals and countries in addressing the issues they deem relevant, Human Development will allow them 
to pick their issues from a compilation of development-related problems, departing from a listing of identified lacks, of identified imperfections that need to be fixed. To me this seems like a form of blindness and deafness to others, their own stories and their own will - their own self-determination. Therefore, the human development discourse legitimizes the existence of development institutions and analysts that, before knowing people, already know these people's issues, while a loving attitude calls for directly engaging with people and, upon difficulties are identified, engage with their transformation. It is a matter of avoiding the violence of diagnosing people's issues. And this non-violent attitude is how love may pose a relevant critique for human development. In a way, there is a correspondence between development and conflict resolution and a correspondence between my critique of human development and elicitive conflict transformation as Lederach proposes.

\section{1- The Millenium Development Goals:}

A decade after Ul Haq's formulation of the Human Development Report and the Human Development Index as the advised policies by the United Nations Development Program, the United Nations created an ambitious plan to manage (italics are not accidental here) development. The initiative known as the Millennium Development Goals (MDGs) comprised a plan of eight goals to be achieved by 2015 , to be coordinated in a "glocal" fashion (global and local) to ensure attaining the specific needs of each country, “accelerating progress". The eight MDGs were:

1: Eradicate extreme poverty and hunger

2: Achieve universal primary education

3: Promote gender equality and empower women

4: Reduce child mortality rates

5: Improve maternal health

6: Combat HIV/AIDS, malaria, and other diseases 
7: Ensure environmental sustainability, and

8: Develop a global partnership for development.

(United Nations Development Program: n.d.)

The final report of the Millennium Development Goals and the renewal of the promise made by governments to achieve the MDGs (from the "Keeping the Promise" report of Secretary General Ban Ki Moon) evidenced that the MDGs were not achieved. Thus, the United Nations Development Program was left with the fundamental task of maintaining their own agenda. To achieve that, they multiplied the MDG's 8 goals into 17 goals, retrieving the idea of sustainability and thus creating the new Sustainable Development Goals, envisioned in the Rio+20 Conference on Sustainable Development of 2012.

Coming from a generation newly exposed to the world after the end of the dictatorship in Brazil, the globalist discourse of development and the local impact of the Rio Conference in 1992 and the following initiatives of the United Nations Development Program, all had the elements to conquer gullible minds that sought to reach out to the world and were instead exposed to the world's malaises from the eyes of development specialists, thus learning about the world instead of learning from the world. In this regard, it is easy to see how its logics become a mindset - up until the moment this mindset starts being challenged. It is at this point that one's own loving capability is relevant: it invites oneself to remain open to different ideas of the world, no matter how much they challenge and change one's previous assumptions, without rejection or reactive attack. 


\section{7- The Critique of Development:}

Discontent with the development project in general began surfacing as early as the 1980s, some twenty years before the MDGs existed. These critiques, mainly addressed in the seminal works by Wolfgang Sachs, Gustavo Esteva and Gilbert Rist, came to form what is nowadays known as the Post-Development School.

These intellectuals were greatly influenced by the poignant critique of Ivan Illich. Illich was an Austrian intellectual and Catholic priest who became influential during the 1970s, in particular due to two of his books: Deschooling Society (1970) and Tools for Conviviality (1975). In his first book, Illich addressed the matters of how public educational systems favoured uniformity and institutionalization of education and how it emptied (empties) other instances as educative experiences. In Tools for Conviviality Illich broadened the critique of education of Deschooling Society to other areas of human activity in order to denounce how Western modern society engulfs other forms of living and how through development practices it generates dependency.

In Tools of Conviviality, Illich (1975) identified that the consolidation of monopolies in several areas that concern the sustenance of human life poses a threat to a healthy society in which its people know, practice and nurture relating with their peers. To Illich, some of these threats were: a costly, qualified medicine as replacement for care in all its traditional and professional forms; schooling by specialized tutors in lieu of an education based on "formation" and training; and political representation and social work that take away from political responsibility and collective well-being. In Illich's eyes, this creation of monopolies of specialized industries, which is presented as progress, as growth, as development, dismantles social fabrics, alienates people from each other, and generates inequality while no pervasive study on the impacts of these specialized industries has been 
carried out: "society can have no quantitative standards by which to add up the negative value of illusion, social control, prolonged suffering, loneliness, (...) and frustration" (Illich: 1975, p. 20).

Illich thus proposes tools that foster people's ability to convivir - to live (well) with each other - and in which individuals are free from dependence on those monopolies. In his own words,

Convivial tools are those which give each person who uses them the greatest opportunity to enrich the environment with the fruits of his or her vision. Industrial tools deny this possibility to those who use them and they allow their designers to determine the meaning and expectations of others. Most tools today cannot be used in a convivial fashion (...). Tools foster conviviality to the extent to which they can be easily used, by anybody, as often or as seldom as desired, for the accomplishment of a purpose chosen by the user. The use of such tools by one person does not restrain another from using them equally. They do not require previous certification of the user. Their existence does not impose any obligation to use them. They allow the user to express his meaning in action. (Illich: 1975, p. 34-35).

Behind Illich's words lies the effort to dismantle manipulatory strategies that lead people to assume they are uncapable of tapping into their own potential vis-à-vis available resources, in order to explore possible answers to the problems faced. That some machines and institutions come to rescue us from working and exploring our potential is a myth in Illich's eyes, as they end up generating dependence at the users' own expense, to the benefit of an élite cast. In this sense, development means getting rid of creativity and labor and reducing it to predefined standards of what "proper" is, usually a service or goods provided by a certified monopolist, specialist. Paradoxically, it is said that dependence of it can only be averted with further use of other services or goods, which feeds environmental degradation, social polarization, obsolescence and frustration.

Well mentioned by Norbert Koppensteiner and Josefina Echavarría in an introductory quote for Martina Kaller-Dietrich's text on Illich, "Illich insists on the need to 
trace, comprehend and then dismantle the link between peace and development as the primary way of challenging the monopoly of the elite over peace, naming this act of defiance as the most urgent task of peace research" (Kaller-Dietrich in Dietrich et al: 2011 p.511). His personal life explains many of the reasons of how his thoughts were formed. Illich grew up in rural Dalmatia and saw how the village erected by the very community little by little disappeared. During wartime, he saw how political power in Nazi times crushed minorities like the Jews. Many years later, after becoming a priest and living in Puerto Rico, he saw how power in the shape of institutions repressed cultural diversity (Kaller-Dietrich in Dietrich et al: 2011).

So, once in Latin America, Illich tried to undo the differencing between "doves and hawks", as both represented the same institutionalized aid work with different approaches, both being united in the effort of fighting poverty in the "Third World". Through his works, he makes clear how the institutionalization of development as a means to achieve peace backfired and turned into one of the greatest tools for exclusion and violence. Nancy Scheper Hughes (Kaller-Dietrich in Dietrich et al: 2011 p.515) mentions that when Illich founded the Center for Intercultural Documentation (CIDOC) in Mexico, the center was an effort to bring wonderment and modesty when confronted with difference. It was an effort to jettison ethnocentrism, as Illich used to teach that "we" comprehend at the same time "us" and also "they". Especially when in many parts of the world the others (they) have been labeled for too long. In the history of Latin America, which is the region I come from, the label shifted from natives to 'underdeveloped'.

It was Illich who pointed out that the war on poverty carried a latent violence, as it led discriminated numeric majorities of peripheral areas such as Latin America to pursue an upper-class lifestyle such as what one finds in the US, separating them from their cradle culture. Illich exposed how the idealist development worker showed up in every violence 
or poverty scenario, while committing himself/herself to serve those in need. Very often they did not understand that instead of remediating the violence and poverty they set out to solve, their role represented the seduction of joining the core of a system that produced the very violence and poverty they were against. As Martina Kaller puts,

in all of his radical deconstructionist writings, Illich challenged us to rethink late modern industrial society, and the perverse social relations that have grown up around it. $\mathrm{He}$ encourages us to free ourselves from the disabling discourses and practices of expert professionalism (Kaller-Dietrich in Dietrich et al: 2011 p.518).

Through Illich's radical deconstruction, one can trace the influence of Poststructuralism in the form of abandoning the binary logics of developed/underdeveloped. Illich understands that the discourse of development can only have a place if the subaltern position of the underdeveloped is reinforced. When Illich criticizes those who advocate a developed welfare state, it is from the post-structuralist idea of preserving diversity and allowing people to refashion their lives based in their own contexts.

Illich thus paves the way for post-development, as a reaction to the ongoing development discourse turned into global project pursued ever since president Truman's speech. Post-developmentalists saw that something seemed wrong with the development project when they realized, among many other issues, that from 1960 until 1980 the gap between rich and poor countries increased from 20 to 46 times (Sachs: 1996, p.xvii). Even though measures such as the MDGs were adopted in the 2000s, the gap persisted throughout the twenty-first century, ignoring much of the critical literature produced three decades before.

German Development Intellectual Wolfgang Sachs could have enjoyed the fruits of growth and development in his own country, but rather decided to take part in the Society for International Development, demonstrating a more conscious sensitivity to the 
reproduction of Western values and lifestyles of his very own social context. In what now has become a classic book for any development or post-development reader - The Development Dictionary edited by Sachs himself in 1992 - one can find a strong, caustic critique of the "decades of brainwashing," which the Development enterprise had imposed on the majority of people. In the introduction of the book, Sachs not only bares several reasons for disbelieving in development but also expresses his anger towards its neocolonialist strategy. Later on, Arturo Escobar argues that development had/has been used as a "pervasive cultural discourse with profound consequences for the production of social reality in the so-called Third World" (2006, p.1).

"Over the year, piles of technical reports have been accumulated which show that development does not work; stacks of political studies have proven that development is injust" (Sachs: 2010, p.xvi). For Sachs, even if development was actually achievable, leading to the level of industrialization that the "developed" countries have, it would require five to six planets to provide all the raw materials necessary to keep it running and to deal with the waste that is produced. Moreover, it would be a matter of injustice to impose over others the responsibility over the consequences of industrialization and environmental damage of the aready developed world. Because of that, it was/is clear that being developed, for Sachs, could not and cannot be an aspiration. This vectoral chronosophy manifested in progress cannot be achieved - or it will lead humanity to extinction. The failure of development is nothing to be feared, rather, we should fear its success (Sachs: 2010, p.xviii).

Sachs also mentions that Development, for the US, was a great tool to "engage the loyalty of the decolonizing countries in order to sustain the US' struggle against communism" (2010, p.2), even if the struggle for development gained more momentum with the ending of the Cold war, when the East-West tensions transformed into North-South 
tensions. Yet, this would take a new characteristic: Instead of prioritizing wealth redistribution, the international agenda found itself focused on the redistribution of risks.

Sachs also questioned if every single group in this planet strove for becoming one developed and politically organized group. More than the idea of the world becoming a boring place (everywhere becoming a replica of a suburb in the United States), he asked: would it not be an irreparable cultural loss if people everywhere wore the same clothes, spoke the same language, and had everything reduced to market consumption? He questioned: what would happen to all the knowledge of other social groups once they were incorporated into mainstream Western life and culture? The fact is that much of it has been lost already and Sachs strives to stop this violence. Because under the development worker gaze, instead of celebrating the difference and diversity of Zapotecos, Touaregs and Rajasthanis, they are all perceived as underdeveloped, poor people who lack the achievements of a consumption society. This is why development from its inception meant the westernization of the world (2010, p.xviii).

The intent of the development dictionary is to stop having corporate executives from International Organizations telling people in the countryside how to live their lives in order to achieve what those executives consider ideal, in this case, development. In order to do so, Sachs organized a book which analyses the history of several different concepts cognitive that the idea of development cannot be separated from it. Some examples include poverty, equality, progress and so on.

In Sachs' book, Gustavo Esteva underscores the reduction of the world after president Truman delivered his speech:

Underdevelopment began, then, on January 20, 1949. On that day, two billion people became underdeveloped. In a real sense, from that time on, they ceased being what they were, in all their diversity, and were transmogrified into an inverted mirror of others' 
reality: a mirror that belittles them and sends them off to the end of the queue, a mirror that defines their identity, which is really that of a heterogenous and diverse majority, simply in the terms of a homogenizing and narrow minority. (...)Since then, development has connoted at least one thing: to escape from the undignified condition called underdevelopment. (...)[To] think of development - of any kind of development - requires first the perception of themselves as underdeveloped, (...) for two-thirds of the world, underdevelopment is a threat that has already been carried out; a life experience of subordination and of being led astray, of discrimination and subjugation. (Esteva in Sachs: 2010, p.2)

In the 1940s, in Mexico City during Esteva's childhood, he was strongly affected by how his indigenous ancestry was systematically reduced in order for him to suffer less discrimination than his parents did. Having a great relationship with his indigenous grandmother, he did not understand why her culture and ethnicity were discriminated against. Despite the fact that he loved spending time in her Zapotec community in Oaxaca, his parents always tried to instill in him the importance of being modern. But around the 1970s, after the great frustration with development initatives in his country and Latin America in general, Esteva managed to reconnect with his cultural background. (Esteva \& Guerrero in Dietrich et al: 2011) This is how he started exploring the origins of the term development and how such a word held (holds) such a strong constellation of meanings. Esteva concludes with how development was a term related to the natural sciences, understood as a process in which a plant or an animal would naturally undergo, and ended up being transferred to the social sciences. However, in the social sciences, development becomes not a natural process of a group or community but an ideal form to be forcefully pursued, an appropriate mode of being, which is not natural but constructed.

Despite that, the word progressively started being applied to the social sciences, especially for those who followed a Marxist line of thought. In Marx's ideas, development became a central issue arguing that through historical materialism society would naturally develop itself towards communism. In fact, Esteva points out that even Hegelian historical 
process entails the connotation of development (Esteva in Sachs: 2010 p. 4), of progress. The greatest issue was that the observation of the past condition allowed men to project it towards the future and it became the manifestation of destiny. Such an idea is the very same that legitimizes colonialism, for instance. Yet Development acquired an even more perverse strategy. As the decolonization process started taking place in Africa, development fitted perfectly as a new ideal for newly independent countries to pursue and base their national credos, therefore colonizing anti-colonial movements. Despite the fact that Latin American countries became independent much earlier than African countries, they still maintained the colonized mentality of perceiving themselves as backward and in a state of poverty. So, it was very convenient for the government of the United States to use the development discourse as a strategy to make the region part of its area of influence against the communist threat and deepen the development mentality.

As the development enterprise unfolded, it is true that there was significant debate over the United Nations. Esteva points that some of the UNESCO experts did promote the concept of endogenous development, which assumed there was no need or reason for other countries to imitate the industrialized Western countries, and that they could/should pursue their very interests according to their system of values. However, this idea would mean a dead end for the theory and real practice of mainstream development. Because of that, no one could assure that such an approach would actually lead to the desired mainstream development, making it an abandoned case.

Arturo Escobar contends that post-development means "an era in which development (...) no longer [is] the central organising principle of social life" (Escobar: 1995), where vernacular cultures are not suppressed, the knowledge and wisdom of ordinary people are heard and taken into account, instead of only expert knowledge. Coming from Colombia and realizing the westernization process of local communities in 
his own country led him to work with marginalized communities, especially with the Proceso de Comunidades Negras (PCN), a community of black people on the coast of Colombia. Seeing how the cultures of these communities were threatened and how the way to extinguish them derived especially from developmental policies created by institutions in which he studied himself, Escobar started challenging those policies. Further, he claims that his thought aims at a sustainable world, both culturally and ecologically speaking (Escobar: 2006). For Escobar, post-development moreover explores the alternatives available to a failed development agenda based on western industrialization. In 1992, Escobar considered that there were few alternatives to deal with the failure of the development project. He noted that if social movements managed to present another powerful strategy to development, they could influence the political and economic practices and change it. However, he noted himself that this would bear the cost of plurality, difference and autonomy (Escobar: 1992).

But the strength of Arturo Escobar's work, rather than betting on the roles of social movements, is to have addressed and tried to answer the critiques made to postdevelopmentalists. According to him, those against the postdevelopment school root their critiques in the facts that (1) postdevelopers had a too romanticized view of local traditions, failing to see that they are embedded in the world powers; that (2) development strategies cannot be generalized and essentialized as there are many different approaches on the ground; and that (3) they focus too much on discourse as a tool of domination, failing to pay attention to the objects of development, that is poverty and Capitalism (Escobar in Clark: 2006, p.448).

To address such matters, Escobar notes that such an approach could never have taken place outside of the context of the twentieth century's last two decades, where poststructural, cultural, feminist, ecological, ethnic and dissident voices gained strength. The 
critiques towards postdevelopmentalists could never have been made if it was not for the very creation of such a "school". Answering the third critique on whether to focus on discourse or material conditions, Escobar notes that it fails to see that Modernity and Capitalism are both interconnected as discourse and practice at the same time. This leads to the necessity of taking seriously the matter of language and meaning in the shaping of reality. Ignoring it has political consequences for him.

While answering the second critique, on essentializing and generalizing development practices, Escobar notices that indeed essentializing development is a serious issue and takes that into account. However, the task of post-developmentalists was not taking into account the contestation and hybridization of the development practices on the ground. The goal of postdevelopmentalists was to tackle the overall discourse and demonstrate the relational coherence of development along with Modernity and Capitalism. Escobar also claims that "we did not try to represent "the real' (of the Third World). This was everybody else's project, and part of the problem from the post-development perspective" (Escobar in Clark: 2006, p.449).

Finally, to address the first critique (about postdevelopmentalists' romanticized views on the peoples' needs and livelihoods, patronizing their interests), Escobar notes a "chronic realism" 16 whenever someone poses a radical critique of hegemonic instances to defend what is vernacular. This would mean that any contact with development and Western thinking would immediately lead to it. Such an assumption clearly cannot be made, as people do have the ability to critically assess their situation. This also ignores people's capacity of organization, which nowadays is condensed into social movements. Plus, Escobar notes that most of the anti-postdevelopmentalists are white men in the north, while postdevelopment advocates are a more diverse group, having lived in both North and South, coming from diverse places and having diverse interests and formations. The matter is not telling how things should be, it is not their intent to be normative. Instead, he stresses what

${ }^{16}$ Maria Mies, on a similar tone, refers to this mania as TINA - There Is No Alternative (Mies: 1999). The term used to be a slogan for the implementation of Margaret Thatcher's liberal politics. 
could be learned from their deconstructions in order to see clearly the consequences of bad field action.

Parallel to this philosophical debate, on a more technical tone, comissioned by the Club of Rome, Donella Meadows along with her then husband Dennis Meadows, Jørgen Randers, and William W. Behrens III published in 1972 a controversial book entitled The Limits to Growth. They relyed on system theories and the World3 computer model to analyse the consequences of growth in population and use of resources.

The Limits to Growth (LTG) reported that global ecological constraints (related to resource use and emissions) would have significant influence on global developments in the twentyfirst century. LTG warned that humanity might have to divert much capital and manpower to battle these constraints - possibly so much that the average quality of life would decline sometime during the twenty-first century. (Meadows, Meadows \& Randers: 2004 position $123)^{17}$

Yet, this book was published 40 years ago, when humans had not caused a footprint beyond nature's carrying capacity. Even though in the 30 Years Update (2004), Donella and Dennis Meadows with Jørgen Randers discuss that it was not their intention to publish something absolutely correct but rather sketch scenarios and work from there, they

stress that humanity is in overshoot and that the resulting damage and suffering can be greatly reduced; (...) offer data and analysis that contradict prevailing political pronouncements that humanity is in the correct path for its twenty-first century; [and] inspire the world's citizens to think about the long term consequences of their actions and choices (Meadows, Meadows \& Randers, 2004)

What is most disturbing is that many of the scenarios predicted by the LTG book seemed to be surprisingly accurate. This is not a matter of criticizing the blind faith of a computer model, but rather requires humankind to rethink their actions when it comes to

${ }^{17}$ Some (older) electronic version of books do not display page numbers, hence, I used the positioning offered by Kindle in this case in order to locate the sentence as precisely as possible. 
their lives and what they pursue in it. This is especially important when development becomes the mainstream conception of living a peaceful life.

\section{8-Alternatives to Development:}

Although this chapter is about the development discourse, it would be incomplete if it did not take in account at least some of the alternatives to development that the poststructuralists so strongly stressed, instead of providing only development critiques. In this sense, bringing in the local approach of Sumak Kawsay in Latin (South) America (Bizerra: 2010), Ecofeminism (Shiva: 1997 and Mies \& Bennholdt-Thomsen: 1999) and Deep Ecology (Næss: 1973), might offer not only examples of vernacular experiences taking shape but might also, as I intend to demonstrate in the third chapter, draws us closer to transrational peaces.

\section{1- Ecofeminism:}

Ecofeminism flourished in the seventies among the diversity of the feminist movement. It focused on fostering a society that, more than eradicating women's oppression, strove for being ecological, decentered, non-hierarchical and non-militarized, respecting the diversity of life and the environment. If traditional feminism originally proposed equal conditions for men and women in the market, outside of home, in the men's world, ecofeminism refrains from falling in such a trap by realizing the threats of such practices to the environment. The difference between traditional feminism and ecofeminism would be that, in an ecofeminist view, women would not have to abandon their households and conquer men's positions in the capitalist job market, but rather could amplify their household-ethics to a world level. 
Among the most famous ecofeminists is Vandana Shiva. Born in India as the daughter of a farmer and a forest conservationist who were strong supporters of Mohandas Gandhi, Shiva follows his message of being the change we want to see in the world. Because she comes from a poor country which quickly came to be considered "developing" (quite similarly to my experience in Brazil), Shiva realized the contradictions of development because the great majority of people remain living in miserable conditions. Because of her close relation to nature, she also saw how development policies and corporations entering her country threatened living resources. Shiva believes that the biodiversity in India is related to the cultural diversity and plurality of knowledges in her country. She is also one of the original Chipko tree-huggers (The Green Interview: 2009). Shiva argues that a male-dominated political world and patriarchal praxis in the context of a globalized economy is not sustainable for the world and cannot offer any lasting solution to the issue of development. She contends that a new paradigm is mandatory to ensure our very existence. In her words:

In an ecological feminist perspective, diversity rather than sameness becomes the possibility for freedom. Striving is not to be competitive but to create space for yourself and for everyone else. To be strong is to know the boundary between protecting your autonomy and allowing other people to exercise theirs. In this sense, power is not power over others but the power to be yourself and allow others to be themselves (Shiva: 1997, p.1).

Ecofeminism stresses the need of recognizing household work as something fundamental for life, denouncing the traditional capitalist and patriarchal systems that do not give value to such form of work. This system goes as far as not considering household work part of a country's Gross Domestic Product. It ignores a sustainable activity that is fundamental when exploitation of natural resources is leading to a huge crisis. 
Ecofeminism proposes a reintegration of humans and nature, sublating the dichotomy imposed since Cartesian thinking. This approach contends significant implications for one's life which affects the political realm, but also goes beyond it. Social relations would not be disciplined through rule but through care. It sees in the historically discriminated and relegated domestic work of women the possibility of a new interpretation of the world as our house and family, bonding everything with love. It contends that this reinterpretation has the power to uplift the contemporary dichotomy between economy and ecology, which in fact have the same Greek root oikos, which stands for the household, domestic, family - the origin of every economic activity.

Vandana Shiva, however, recognizes that she is accused of essentializing womenhood. In answer to that, she argues that ecofeminism "has never required it to be said that women are biologically closer to nature" (1997: p.2) but rather that our unity with nature is true to everyone, whether men, women or children. Shiva mentions that "it is ecological blindness to assume that humans can so insulate themselves from the natural world and what brutality we subject it to, (...) to assault nature and live privileged situations for ourselves" (1997: p.2).

Maria Mies is another ecofeminist who has worked with Shiva. In the 1999 book she wrote with Veronika Bennholdt-Thomsen titled The Subsistence Perspective, they derive the key for an economic change from the experience of women in their everyday life, producing their most basic needs. With many stories of household and peasant work of women, they demonstrate that another relation to nature and to human beings is possible. They explain how patriarchy and financial capitalism (through globalization), instead of understanding that women and nature are the ones who produce food and maintain life (Mies \& Bennholdt-Thomsen: 1999, p.80), relegate both women's and peasants' work to a 
second category by making money and its purchase power the producer of life (Mies \& Bennholdt-Thomsen: 1999, p. 58).

With this, Mies and Bennholdt-Thomsen manage to reclaim the importance of the subsistence peasant work (for the peasants are the ones who work with nature to produce the food that maintains life), differentiating it from agriculture or farming (which is work for profit-making). The difference is that peasantry represents diversified small farms and home gardens with little impact while farming represent an industrial agriculture. They show that such a peasant life is not, as a developmental approach would regard, filled with deprivation, but rather with abundance, joy and proximity to other living beings - animals, plants and the soil, which opens people up to be touched by them. The features that a subsistence perspective brings, according to the authors are: change in the sexual division of labour; production geared towards needs not wants; technology that should be used not to control nature but to cooperate with it - respecting its limits to regenerate life, respecting biodiversity; a new set of economical praxis with local markets and seasonal products for subsistence and never profit; and a change in the concept of need and sufficiency, with satisfaction of human needs and not accumulation of surpluses and reciprocal relations between rural and urban areas (Mies \& Bennholdt-Thomsen: 1999, p. 62-63).

\section{2- Deep Ecology:}

Now very close to Ecofeminism is the approach of Deep Ecology. Deep Ecology was proposed by Norwegian philosopher Arne Næss as a reaction to "shallow" ecological initiatives like resource conservation and value assumption of soils for the sake of human beings only and not for nature itself. From that, Arne Næss came up with the Eight-Point Platform of Deep Ecology, which provided the unifying principles of the deep ecology 
movement. The intention was to shift from an anthropocentric worldview to a biocentric egalitarianism in which a relational self leads to eco-consciousness. The eight points are:

1- The well-being and flourishing of human and non-human life on Earth have value in themselves (synonyms: intrinsic value, inherent worth). These values are independent of the usefulness of the non-human world for human purposes.

2- Richness and diversity of life forms contribute to the realization of these values and are also values in themselves.

3- Humans have no right to reduce this richness and diversity except to satisfy vital needs.

4- The flourishing of human life and cultures is compatible with a substantially smaller human population. The flourishing of non-human life requires a smaller human population.

5- Present human interference with the non-human world is excessive, and the situation is rapidly worsening.

6- Policies must therefore be changed. These policies affect basic economic, technological, and ideological structures. The resulting state of affairs will be deeply different from the present.

7- The ideological change will be mainly that of appreciating life quality (dwelling in situations of inherent value) rather than adhering to an increasingly higher standard of living. There will be a profound awareness of the difference between bigness and greatness. 8- Those who subscribe to the foregoing points have an obligation directly or indirectly to try to implement the necessary changes. (Naess in Sessions: 1995 p.68)

Naess' deep ecology finds a particular echo in Joanna Macy's and Molly Brown's book titled Coming Back to Life (2014). Macy is an ecophilosopher, activist, buddhist and system's theory scholar involved with international movements of civil rights, global justice and ecological justice while Brown is an ecopsychologist working with psychosyntesis at Mount Shasta, which is a sacred site to native communities of the area (Macy and Brown: 2014, p.342-343). Both Macy and Brown facilitate a "Work that Reconnects" workshop, "to foster the desire and ability to take part in the healing of the world" (Joanna Macy: 2019), overcoming fear and paralysis in the face of severe ecological consequences. 
Macy and Brown see how an "Industrial Growth Society" generate worldwide suffering through the poisons of greed, aggression and delusion, all of which manifest in a development mindset: greed for generating richness, agression when overlooking the environment, and delusion by denying that a development project affects living beings negatively, despite a long list of evidence. But Macy and Brown see that "it is possible to meet our needs without destroying our life support systems" (Macy and Brown: 2014, p.3), particularly through " 1 . Actions to slow the damage to Earth and its beings 2 . Analysis and transformation of the foundations of our common life 3. A fundamental shift in worldview and values" (Macy and Brown: 2014, p.6).

Molly Brown's personal biography is particularly telling of the importance (and challenges) of working with one's heart and exercising her capability of loving and its relation with an ecological attitude that is critical to a development project. Raised at Los Alamos in New Mexico (USA), a city designed exclusively for hosting the laboratory that conducted the research of the Manhattan Project, Molly Brown had an innate understanding that the city she grew in was entirely geared towards life destruction. She painfully realized that those nice and friendly neighbors of hers were also deeply involved in a trance-like form of "rationalization, justification and deception" for a project of mass extermination via nuclear weapons (Macy and Brown: 2014, p.xxix). These realizations, at first not evident to and cognized by her, took the shape of illness and, as she started taking care of herself, her care activated awareness on caring also for the planet, which led her to become very critical of the entire Los Alamos nuclear weapons project and all other ecologically imbalanced projects, thus becoming and activist against them and advocating for an ecological life style closely related to Deep Ecology. 


\section{3- Buen Vivir:}

Lastly, I would like to explore another alternative to development, called in Ecuadorean Kichwa Sumak Kawsay, in Bolivian Aymara it is called Suma Qamaña or, in Spanish, Buen Vivir (good living). In Cecilia Bizerra words, Buen Vivir means a

solid principle which means life in harmony and equilibrium between men and women, between different communities and, above all, between human beings and the natural environment of which they are part. In practice, this concept implies knowing how to live in community with others while achieving a minimum degree of equality. It means eliminating prejudice and exploitation between people as well as respecting nature and preserving its equilibrium. (Bizerra: 2010, n.d.)

Buen Vivir was first presented in the World Social Forum in 2009 and commented on by Gustavo Esteva in an article titled America Latina en Movimiento in the same year, and gained particular force in the region. Long preceding the 2009 World Social Forum, in 1982, the Working Group on Indigenous Populations (WGIP), created within the United Nations Sub-Commission for the Prevention of Discrimination, facilitated the creation of a network of indigenous movements, while the Catholic Church had greatly supported the articulation of latin american indigenous communities at the last quarter of the twentieth century. At the turn of the first decade of the twenty-first century, within a political environment empathetic to an inclusive mode of governance, indigenous organizations were invited to take part in the national assemblies in countries such as in Colombia, Ecuador, Nicaragua, Panama, and Guyana, having been incorporated in the constitutions of both Bolivia and Ecuador, turning them into plurinational states. (Martí i Puig: 2010)

The initiatives mentioned above intended to address the historical exclusion of indigenous cosmovisions and create a debate over a plurality of socio, political, economic, and environmental modes of being and living, out of which Buen Vivir stood as a resistance to the hegemonic of Western values dominant from the European invasion, passing through 
colonization, independence, and well into the twentieth century globalization phenomena with current neoliberal, capitalist market practices, universalized particularly through (maldevelopment practices. Buen Vivir, instead, is centered on the indigenous populations' claim to define in their own terms the way they want to lead their lives, in a way that there can be a balance between all communities, the cultural heritage and the Pachamama. In fact, the Consejo Indigena de CentroAmérica (CICA) contends that Buen Vivir is "la expresión de una Vida Armónica en permanente construcción (...) en directa vinculación y equilibrio con la naturaleza" (Consejo Indigena de Centroamerica: 2020) ${ }^{18}$ that it is rooted in the underlying cosmovisions of Native-American indigenous communities and their own forms of organization. Leonardo Boff contends that

El "buen vivir" apunta a una ética de lo suficiente para toda la comunidad, y no solamente para el individuo. El "buen vivir" supone una visión holística e integradora del ser humano, inmerso en la gran comunidad terrenal, que incluye además de al ser humano, al aire, el agua, los suelos, las montañas, los árboles y los animales; es estar en profunda comunión con la Pachamama (Tierra), con las energías del Universo, y con Dios. (Boff: 2009, p.1). ${ }^{19}$

As an ecocentric mindset, Buen vivir thus presents a coherent discourse which may function as an alternative to the development rationale. What remains to be done is a consideration of whether it has produced any further impacts since, for instance, its grand feature of landing into the constitutions in Bolivia or Ecuador.

The recent October 2019 protests in Ecuador, strongly defended by indigenous groups against the rising of oil prices (which contaminate the environment), expose issues

${ }^{18}$ The expression of a Harmonious Life in permanent construction (...) in direct relation and balance with nature. Translation by Egidio de Bustamante.

${ }^{19}$ The Buen Vivir points to an ethics of what is enough for the whole community, and not only for the individual. It entails a holistic and integrative vision of the human being, immerse in the great earth community, that also includes beyond the human beings the air, the water, the lands, the mountains, the trees and the animals. It means being in deep communion with the Pachamama (Mother Earth), with the energies of the Universe, and with God. Translation by Egidio de Bustamante. 
at the heart of buen vivir-derived policies. The October 2019 protests in Ecuador are just a part of a long-standing indigenous claims for their lands and their ancestral, limited, and conscious use of resources. These protests typify and echo the criticism made by Domínguez and Caria in 2014, that buen vivir has become an "ideological apparatus" for States to mask GDP-growth centered, "humanized" capitalist and developmental practices through the exploitation of natural resources - especially oil, which are all championed in the name of combating inequality (Domínguez \& Caria: 2014). These State-supported practices clearly fail to prescribe to the basic tenets of buen vivir in its concern for equality, the pachamama and good living of indigenous peoples.

The issue does not derive from contradictions within the buen-vivir perspective in itself, though, but from the Ecuatorean State failing to understand that, underlying the cosmology of Buen Vivir, is a call to a pluriverse or multiverse (see Kothari et al: 2019). The pluriverse perspective not only contends and celebrates the coexistence of different cultural expressions, but explicitly calls to act in solidarity with indigenous, ecocentric traditions. This act of solidarity would require a fundamental change in all State practices that dominate nature and reproduce inequality. Sustaining a communitary living in which human beings are woven back into nature and become just another parcel of the environment, in which spirituality is a present aspect of being, makes any discussion on sustainability irrelevant, as this communitary living would already be sustainable from the start. In this pluriverse or multiverse,

there are many paths towards a bio-civilisation, but we envisage societies that encompass the following values and more: diversity and pluriversality, autonomy and self reliance, solidarity and reciprocity, commons and collective ethics, oneness with and rights of nature, interdependence, simplicity and enoughness, inclusiveness and dignity, justice and equity, non-hierarchy, dignity of labour, rights and responsibilities, ecological sustainability, nonviolence and peace. (Kothari et al: 2019, p.xxix) 


\section{9- Final considerations on Development:}

In the first sections of this chapter, I outlined the concept of development, pointing out the many sociological, political and economic perspectives that compose it. All deriving from a Modern conception of the world), and how it becomes a discourse that is expressed globally as the quintessential policy carried out by every national government. I proceeded by organizing and presenting the critique of development conformed in the "postdevelopment" school and, finally, presented their main dissident voices. Finally, I devised what some would call alternatives to development.

This results in the realization of development as a well-meant but still paternalistic approach towards the lives of others and, as such, an ill-conceived policy, that rejects people's own process of unfolding by determining what they ought to do and be: a better, richer, and more appropriate conception of themselves. Likewise, the development discourse is fundamentally at odds also with Freire's contribution to love (even in the Marxist conception of development when Freire was himself a strong Marxist voice). The concept of development, like a banking method of education, divests people from exploring their own consciousness over sustainability and the power to be ecologically prone decision-makers in their lives. Freire's love calls for and maintains an open dialogue towards people's own process of transformation - an earnest and continuous encounter with the other for collective enrichment. These are directly connected with Vattimo's foreverbeing-with others and giving radical attention to them.

From a perspective of love, such radical attention is no easy task. Especially because, in the words of Joanna Macy and Molly Brown:

[1]iving within a society that denies the pain it causes engenders deep conflict within us, but 
the taboos against speaking of it, or even seeing it, are subtle, strong and complex. Being nice - even being intelligent - means going along with the communal deception, like the mutually shared trance of an alcoholic family. Yet we do ourselves and the larger world real damage when we go along with the taboos and deny the truth of our inner knowing, as I did for so long. (Macy and Brown: 2017 p.xxx)

If any understanding of love as a mere moral commandment of being nice remains, with the quotation above it becomes clear that loving is a difficult challenge that demands compassionate ways of engaging with others, especially if loving others requires being critical and requesting change, in lieu of keeping an unsustainable status quo for the sake of being on good terms. And, after an exhaustive analysis of how a development mindset and world project drives an ecological and social degradation, a perspective of loving becomes evidently connected to critiques of development and especially so with alternatives to it. From such perspective, Ecofeminism and the subsistence perspective, buen-vivir and deep ecology all point to ways of living that places humans in permanent connection with their environment and other living-beings. Thus, they shift from an anthropocentric perspective which befits Thich Nhat Hanh's concept of love as inter-being. Rewoving humanity into nature is akin to Levina's encounter and fusion with the other, and understanding may take place - the same understanding that Freire desires, even if nature does not communicate verbally. This is why at times ecologists refer to the cry of mother earth. Being able to hear it requires exploring one's sensibility:

we can cut through denial and take a good hard look at the dysfunctional economic system that has captured humanity and is destroying our life-support system. This is not who we really are: self-centered, arrogant, greedy, contemptuous of other humans and life-forms. No! We have been hijacked by an insane, alien culture of our own foolish making. Let's reclaim our true humanity: loving, generous, caring, connected and joyful, heroic, persevering, willing to endure suffering as part of life, heart-centered, creative and wise (Macy and Brown: 2017 p.xxx). 
With the warnings on the environmental impact and the damages already done to life in general from the industrial-based economic development, a sustainable change will require us to explore our potential for genuine good, rethinking our own self-conception and diligently integrating it into our relationships with other living beings. 


\section{Chapter 5- Love and International Human Rights:}

Human rights are but one way that has been devised to realize and to protect human dignity. Although the idea of human rights was first articulated in the West in modern times, it would appear to be an approach particularly suited to contemporary social, political, and economic conditions, and thus of widespread contemporary relevance both in the West and the Third World. (Jack Donnely: 1982, p. 303)

\section{1- Introduction:}

For the last section dedicated to international studies, in this chapter I explore the human rights discourse as constituting part of international studies, and the deriving reflections from a perspective of love. In this chapter, I dwell on the context in which the discourse of Human Rights was created and its fairly recent history, in an eminently international environment, despite traditional assumptions of it as continuum from a much earlier history traced $\grave{a}$ la archaeological research. Below, I present the most poignant and contemporary critiques made to human rights and come to make final observations on what it means to hold a critical perspective of love towards it.

\section{2- Origins of International Human Rights:}

Can words provide an accurate account of what it means to witness the death of more than 50 million people in just 6 years? What does it mean to observe 100 million people involved in the war industry, more than 30 countries directly involved in a military 
conflict, airstrikes and atomic bombs being launched onto people? What does it mean to be in a total war? What does this experience make one feel? The pain generated by such a large-scale annihilation of human life cannot but leave deep marks onto one's heart, if it has not torn hearts completely. In a moment when most of the world found itself with their hearts broken, mourning their losses and experiencing the pain of the crude violence of the Second World War, it was no surprise that such painful trauma would demand attention on a global scale.

To this shocking situation, leaders of several countries responded to their countrymen by participating in the Dumbarton Oaks Conference of 1944 to discuss the creation of a future international institution, modelled by and aiming to replace the shortcomings of the League of Nations, which had perhaps too soon failed to contain the violence of World War I - a rehearsal for the horrors of World War II. Despite its name, the League of Nations was a mostly European institution without representatives from then global player countries such as the US and the USSR, without representatives from most countries from the global south. The League was also an institution which failed to address the Japanese expansion in the 1930s. Therefore, in an effort to overcome the tragic situation of the League of Nations, the Dumbarton Oaks Conference sought a new, more inclusive organization than the League. This led to a second meeting in San Francisco in April 1945, to establish a new international institution capable of responding to the recurring crude reality of war and to envision a world in which such capacity for destruction no longer existed, (while World War II still claimed lives). Their intentions were the following:

\section{WE THE PEOPLES OF THE UNITED NATIONS DETERMINED}

to save succeeding generations from the scourge of war, which twice in our lifetime has brought untold sorrow to mankind, and

to reaffirm faith in fundamental human rights, in the dignity and worth of the human person, in the equal rights of men and women and of nations large and small, and to establish conditions under which justice and respect for the obligations arising from 


\section{treaties and other sources of international law can be maintained, and}

to promote social progress and better standards of life in larger freedom,

\section{AND FOR THESE ENDS}

to practice tolerance and live together in peace with one another as good neighbours, and to unite our strength to maintain international peace and security, and

to ensure, by the acceptance of principles and the institution of methods, that armed force shall not be used, save in the common interest, and to employ international machinery for the promotion of the economic and social advancement of all peoples,

HAVE RESOLVED TO COMBINE OUR EFFORTS TO ACCOMPLISH THESE AIMS Accordingly, our respective Governments, through representatives assembled in the city of San Francisco, who have exhibited their full powers found to be in good and due form, have agreed to the present Charter of the United Nations and do hereby establish an international organization to be known as the United Nations (United Nations: 1945, preamble)

Establishing their raison d'être, the Charter above became the document that established the United Nations. Their concern was genuine and critiqued what became of this international "machinery" - in their very own words - an aspect to be discussed ahead in this chapter. In any event, in the ambitious structure proposed in the Charter, the United Nations originally comprised a General Assembly, a Security Council, an Economic and Social Council, a Trusteeship Council, an International Court of Justice and a Secretariat in which all dimensions of life would be discussed with the intent to safeguard humanity and liberate human capabilities to explore its potential in peaceful coexistence.

Under article 68 of the UN Charter, the Economic and Social Council (ECOSOC) was to establish a commission for the promotion of human rights, as a frame in which people could nurture their abilities to peacefully relate and enshrine human dignity. The debates on what would become the United Nations Commission on Human Rights took place over ECOSOC's first and second sessions in 1946, when a nuclear commission studied the proper body and function the commission should have. Along with that, the nuclear commission requested the United Nations Secretariat to collect information on the 
matter of Human Rights to give the Commission operative content, which it did through its Division of Human Rights, under the responsibility of Canadian jurist and scholar John Peters Humphrey (The Hampton John Peters Humphrey Foundation: n.d.).

The United Nations Commission on Human Rights was established in that same year (1946). The Commission held its first meeting already in February 1947. At the occasion eighteen members from various nationalities and cultural, political and religious backgrounds were selected to tailor the International Bill of Human Rights. This Bill was supposed to contain a declaration, a covenant and implementation measures on human rights (United Nations Human Rights Council: 2019) and whose draft had been sketched by John Humphrey while in the Human Rights Division of the United Nations Secretariat. This document served as a blueprint to the future Universal Declaration on Human Rights (UDHR).

Along with John Humphrey in the drafting committee was Eleanor Roosevelt (widow of American President Franklin Delano Roosevelt), serving as chair of the committee. Under her leadership, many people collaborated, including Charles Malik, a Lebanese diplomat and existentialist philosopher (former student of Martin Heidegger); Chinese diplomat and Confucian philosopher Peng Chung Chang (former student of John Dewey); and French scholar and judge René Cassin, who would later prepare the first draft of the UDHR). The discussions carried out by this drafting group were not an easy one, as there sat together a French Jew defender of a Jewish State who had lost over 20 relatives in the Holocaust (Cassin), a representative of the Arab League (Malik) supporting Palestinians, and a Confucian philosopher (Chang) questioning the Western premises of the draft and the appropriation of Confucian content in the Islamic perspective held by Malik (even though Malik was an Orthodox Christian). Because of the difficulties found in the process of drafting such a legal document, the Human Rights Commission requested 
the United Nations Educational, Scientific and Cultural Organization (UNESCO) to provide a study onto a common language that reflected all human philosophies in their diverse religious, intellectual and cultural backgrounds. (Ishay: 2008, p.220)

Addressing those difficulties in the introduction of the UNESCO's study, Jacques Maritain noted that many schools of thought have each contributed to the rational interpretation and justification of Human Rights, notwithstanding their different and even antagonistic views (Maritain in UNESCO: 1948). In this light, Charles Beitz (2003) contended that the issue remained mostly in the agreement over the philosophical and theoretical foundation of human rights, rather than in its content. Their hearts were on the "same page" on the sacred-like nature of human life, but the arguments each drew from seemed limited. To this thought, Maritain added that even when two or more people are intellectually divided between a matter and each of them claim to hold the truth, the basic principles of action could arise and, grosso modo, a common denominator could be found, regardless of how incompatible the individuals' positions may be (Maritain in UNESCO: 1948, p.I-III).

Is there anything surprising in systems antagonistic in theory converging in their practical conclusions? (...) The phenomenon proves simply that systems of moral philosophy are the products of reflection by the intellect in ethical concepts which precede and govern them (Maritain in UNESCO: 1948, p.IV)

Maritain explains that such a situation (in which difference remains and yet dissolves itself into concessions and common understanding) had to do with the dynamics and focused interaction of the group tasked with drafting the soon-to-be Universal Declaration of Human Rights. For Maritain, the entire experience had to do with the drafters grasping each other's intentions behind any chosen written form. It is no less true that the chosen language would greatly benefit the intentions behind the written form on human dignity (thus the importance of linguistic coherence and clarity in any authentic declaration 
that stands for care and concern over humanity); however, care is the drive behind the use of language, and language gives shape to care. That is no less true on a global scale when spoken languages are so diverse.

But whenever language fails to encapsulate the concern over suffering, then it either has to be changed, or give in to other vehicles of engagement. These other forms of engagement should nonetheless entail an attitude that denotes unwavering presence (as companionship), focused care and attention (as support), with the purpose of fostering healing and reinforcing resilience. The fact is, tuning into those other forms of action renders language just one way of addressing human dignity, and that is precisely what Maritain noticed: in that space in which the International Bill of Rights was being weaved, multiple forms were found to address human dignity, even if the outcome, as something concrete and measurable, had to be expressed as language and, eventually, as norms.

The situation above attests to the idea that before any positive right of an individual comes the concern for being a fully realized human. It is in this light that, according to Maritain, "spontaneous reason, pre-scientific and pre-philosophic", is something previous, larger and deeper than the agreement on the best way to convey and express this understanding. This, again, cannot mean that wording and phrasing (framing, in general) do not matter - and the contemporary clashes and debates (further ahead in this chapter) attest to that.

Perhaps those committed to discussing a future bill of rights were unaware of it, but in discussing the culturally, contextually-bound ethical-intellectual concepts guiding each of them, they were also engaging in those forms of care through their own actions, trying to honor human life in all its dimensions and the peoples they represented and served. This road taken towards human encounter and deep concern for human life is but an expression 
of love, a form of addressing the unrealized human need for fulfillment and liberation from suffering, a key aspect in Thich Nhat Hanh's Mahayana Buddhism.

In this vein, it can be argued that love as realization of humanity and the according diligent service is a fundamental aspect in which all different cultural expressions converge and meet, even so in the drafting of the Universal Declaration of Human Rights. This is how Chilean diplomat Hernán Santa Cruz, with a more Christian language, described thus the moment in which the General Assembly of the UN adopted the Universal Declaration of Human Rights in December $10^{\text {th }}, 1948$; two years later after the discussions on the draft of the declaration:

I perceived clearly that I was participating in a truly significant historic event in which a consensus had been reached as to the supreme value of the human person, a value that did not originate in the decision of a worldly power, but rather in the fact of existing - which gave rise to the inalienable right to live free from want and oppression and to fully develop one's personality. In the Great Hall...there was an atmosphere of genuine solidarity and brotherhood among men and women from all latitudes, the like of which I have not seen again in any international setting. (United Nations: 2019)

Santa Cruz did not refer to love in his speech, and it might not have been necessary to do so, as the nurturing and heartfelt connection he experienced and commented on his speech attests that what Maritain considered pre-rational. Plus, as stated also by Erich Fromm, brotherhood is one fundamental expression of love.

The declaration was approved in the occasion of Santa Cruz's speech after two years of efforts in weaving together the most fundamental rights of every individual. The declaration departed from the premise that the inherent dignity of all human beings is the foundation of peace. And yet, just like care calls for a reflection into how one can be of service to others, it is hard to discuss human rights without discussing the actions that may sustain it. Or, in other terms, how the concern over human rights takes place in practice and what is further required to sustain committed, continuous service. 


\section{3- Enforcement and Forerunners of International Human Rights:}

The actions to sustain the Universal Declaration of Human Rights (UDHR) and give it practical value could not be of a precarious nature, since the very reason of the entire bill of rights was to curb the fear of widespread suffering and violence through the establishment of a legal system of protection. Therefore, the concern for human life that stemmed from the drafters and that was weaved into the UDHR, had to morph into carefully laid out duties to be ensured by governments ruling nation-states, thus positivizing the respect for and the promotion of human dignity through human rights, guaranteeing them.

Although the UDHR was consensually accepted by the majority of dignitaries of all countries in the General Assembly, ${ }^{20}$ in practical terms, it was not legally binding as, due to lack of time, the convention and the measures of implementation were not submitted to plenary appreciation. Therefore, the General Assembly requested the Commission on Human Rights to continue its work by weaving a draft Convention that could be enforced - that is, made into an explicit norm for states to follow and be sanctioned in case they did not - which took place between 1949 and 1951. At this point, the idea of enforcing human rights could amount to a problem, when care over fellow human life as spontaneous act becomes an obligation towards something distant and abstract, imposed onto people who have not had the opportunity to realize its fundamental nature. Rather than a stimulus for the realization of the value of human life and ensuing attitudes, they may turn into a literal enforcing - an imposition. Yes, there is a fundamental risk in overlooking positive norms, but nothing justifies violence.

${ }^{20}$ Some countries, however, did abstain from voting: The Soviet regimes at Belarus, Czechoslovakia, Poland, Ukraine, USSR, and Yugoslavia, and also Saudi Arabia and South Africa, and Honduras and Yemen did not vote (Ishay: 2008 p. 223) 
Regardless of this debate, contradictions between the declarations of support for human rights and the actions to ensure them became most apparent. As willing as people partaking in the Commission were to respect and celebrate human dignity in the form of established rights, the idea of condemning or making liable those who violated such rights seemed like a step that needed to be taken with caution and due study. And also, this context was a perfect opportunity for governments to push for their interests within the collective decision on how to enforce human rights. In the dawn of the Cold War, in which the delicate balance of power between the US and the USSR could be easily shaken by UN resolutions that favored one party's perspective over the other, the debates on this final Covenant became ground for dispute of political interests.

The rift started to become more explicit after the USSR started advocating for rights of an economic, social and cultural dimension, which would lean towards a socialist system. For them, they would come before civil and political rights (United Nations Economic and Social Council: 1948) championed mostly by the governments led by the US and France based on their respective Amendments to the Constitution of the United States and Déclaration des Droits de l'Homme et du Citoyen, both documents dating back to 1789. Eventually, the UN's General Assembly would decide to include economic, social and cultural rights in the covenant on human rights, considering them connected but independent from civil and political rights (United Nations General Assembly: 1950). Due to the dispute about, the most relevant aspects of human rights, the General Assembly of the United Nations eventually advocated for the creation of two different documents that responded to both aspects (civil and political rights versus economic, social and cultural rights). Avoiding the Cold War competition in the discussion, the Assembly declared that both covenants had equal importance in the eyes of the United Nations, and thus requested them to be presented at the same time. The draft Covenant on Civil and Political Rights and 
the draft Covenant on Economic, Social and Cultural Rights were completed between 1953 and 1954. Only after an article-by-article discussion, that lasted over 10 years - until 1966, Covenants entered into force, in 1976 (Office of the High Commissioner for Human Rights: 1996). From this point, the Universal Declaration of Human Rights, the Covenants on Civil and Political Rights and on Economic, Social and Cultural Rights, combined with their respective protocols, would become, at least in principle, a universalized standard regarding the dignity of human beings.

But what are the fundamental differences between both covenants? Although both covenants were presented at the same time, a common way to explain the difference between civil and political rights versus economic, social and cultural rights was proposed by Franco-Czech jurist Karel Vasak, who conceived them as different generations of rights (Vasak \& Alston: 1982). In simple terms, the first generation of rights were based on the Articles 1-21 of the UDHR, relating to the right to live, the prohibition of slavery and torture, and the right to a fair trial; freedoms which were easier to legislate as they encapsulated protection from the State, alluding to the implementation of a democratic government (hence the USA's advocacy for their primacy during the debate that took place over the Cold War). The first generation was concerned with matters of citizenship, of protecting humans against the abuses of their nation-state.

Meanwhile, the second generation referred to articles 22-onwards in the UDHR, specifying rights that were to be granted by the State as minimum conditions to live, such as the providence of food, of health, of education and of work and its necessary conditions, central concern in socialist countries and thus reasonably championed by the USSR. These rights focused on those aspects that sustained human life before the exertion of citizenship. According to Karel Vasak, there would also be a third generation of human rights. In his own words, "Such rights include the right to development, the right to a healthy and 
ecologically balanced environment, the right to peace, and the right to ownership of the common heritage of mankind (...) these rights reflect a certain conception of community life" (Vasak: 1977, p.29).

The debate on generations raised by Vasak, however, cannot but reflect a certain order between those different groups of rights, and thus hierarchy. To give primacy to civil and political rights, considering them the very first forms of rights, implies that the sole manner for humans to socially organize ourselves is in the form of Nation-States. It also necessarily ranks second those aspects that do respond more directly to human life (which compose the "second and third generations" of human rights). Further, looking at the third generation the hierarchy between human beings, other living beings and the planet is explicit too. Clearly, the covenants understand people first as citizens, then as individuals and, finally, acknowledges the primacy of human life above other forms of life.

The debate above, and the very context it took place (The Cold War, with the US and the USSR trying to place their favored covenant first), elicits different kinds of debate. More specifically, the debate on how adequately we as human beings come to organize ourselves, what we understand as dignity and the efforts made to safeguard and standardize it. As such, this calls for an archeology of human rights before the universalization of such discourse. It is thus fair to ask whether such relevant aspects of human life does not entail a larger history than the one relating to the Creation of the United Nations System after World War II. The short answer to that is yes. At least within the West, it is commonly accepted that the very first compilation of laws regarding human life was introduced by King Hammurabi of Babylon in around $1800 \mathrm{BCE}$, in a code containing 283 provisions, which came to be known as the Hammurabi Code. This code might be far from what is considered human rights today, as it defended most cruel punishments, but it represents the first documented tabulation of norms organizing society. From that, according to Michael 
Haas, a set of the documents that constitute the conventional early history and genealogy of human rights generally include, and date back to the Torah, the Cyrus Cylinder, the Christian Gospels, the Constitution of the city-state of Medina, or the English Magna Carta; likewise, the constitution of the United States, the French declaration, the slavery abolition, all represent relevant marks in legal history, which directly influenced human life (Haas: 2008, p.44-48).

Historian Kenneth Cmiel, however, points to the importance of "not treating assertions of human rights in hushed, reverential tones" (2004 p. 126) as otherwise Jesus, Buddha, or any form of genuine concern over human beings becomes a human rights perspective and yet none of them were thought in the ways we think of human rights today. The point Cmiel makes is the contemporary specificity of Human Rights as a human concern. Cmiel considers that the international debate's emphasis on human rights but a twentieth century novelty. He points out that "activism" on human dignity was always a domestic concern and to the international eyes, what nations did inside their borders was their own matter. This only changed after the monitoring of basic human rights in 1940 during war, and in different waves that comprised the growth of transnational networks of human rights activism and culminated in the international laws against genocide in the nineties, which was considered a high period of globalization (Cmiel: 2004 p.130). The deriving argument is that one needs not to be a human rights defender to be a humanist.

In a similar vein to Cmiel, Samuel Moyn explains that Human Rights is much more recent than the 1940 s, as he considers that the human rights discourse only really became global after the 1970s, remaining the last standing utopia while political alternatives to US hyper-individualistic, capitalist consumerism such as Socialism, Communism, and Anticolonialism also started losing credibility, amid a great struggle of NGOs to arouse curiosity over the relevance of human rights. For Moyn, human rights has become a 
lighthouse and scapegoat for contemporary international politics, and historians of the term (Moyn: 2010, p.6).

Differences within these historian's perspectives apart, the debate of human rights as we know it is undisputedly placed within the international sphere of the twentieth century

global politics, becoming a political buzzword and a flag championed for many international policies and, obviously, to peace and peace studies - hence its very inclusion in this thesis. This is the reason why it is important to understand Human Rights as International Human Rights (IHR), though, to avoid being repetitive when writing it down, I drop the expression "international". Despite IHR does not focus on the juridical aspects of human rights, there is little doubt, however, that Human Rights have become one of the most powerful discourses in the international domains.

\section{4- Critiques to International Human Rights and reactions:}

Despite both Cmiel and Moyn's critique that the history of Human Rights is a rather recent one, and their caution of uncritically championing of human rights, ahistorical defenses of human rights not only abound, they also pave way to grand assertions on their own importance. These are, then, unsurprisingly charged with imperialism (Cmiel: 2004 p. 120). To un-do imperialistic, uncritical, and ahistorical perspectives over human-rights, it becomes important to visit current debates on the human rights and reveal their theoretical and philosophical underpinnings in order to assert their appropriateness and coherence with a perspective of love, defended in this work as a quintessential aspect of peace, peace work and peace research. Therefore, this is exactly the task taken in this section. I revisit current 
debates $^{21}$ and have them dialogue with the love perspectives laid out in chapters one and two of this thesis.

\section{1 - Universal Human Rights?:}

Perhaps the strongest underpinning of human rights relates to its universality. The idea that human rights are universal, regardless of whether states have ratified the Human Rights Covenants or not, bears direct relation to the idea of human rights as natural law. The central tenet of natural law is the assumption that all individuals are naturally moral, as God created them endowed with reasoning that safeguards them so they can lead their social lives, a perspective attributed mainly to Dutch scholar Hugo Grotius. Having lived in the turn of the XVI to the XVII century, Grotius's thought is a substantive representation of the experiences that the Netherlands, and Europe, were then passing. Grotius was born after the Protestant Reformation disputes and lived through the 30 Years War, trying to come to terms with and dissociate life from religious matters, which heavily influenced people's every day in his time. Grotius' work De Jure Belli Ac Pacis of 1625 reflects his effort to conceive a peaceful human life within the confusion of laws that are safeguarded by the state but which are ultimately God-given, yet a natural trait of human rationality:

Natural right is the dictate of right reason, shewing the moral turpitude, or moral necessity, of any act from its agreement or disagreement with a rational nature, and consequently that such an act is either forbidden or commanded by God, the author of nature. The actions, upon which such a dictate is given, are either binding or unlawful in themselves, and therefore necessarily understood to be commanded or forbidden by God. This mark distinguishes natural right, not only from human law, but from the law, which God himself has been pleased to reveal, called, by some, the voluntary divine right, which does not

\footnotetext{
${ }^{21}$ These debates on Human-Rights discourse are significantly drawn from the critiques of Western colonialism and the search for new "grammars" for human dignity, which are defended by the thought of Boaventura de Souza Santos and the Centro de Estudos Sociais at Coimbra University, where I held a research stay for the composition of this chapter.
} 
command or forbid things in themselves either binding or unlawful, but makes them unlawful by its prohibition, and binding by its command. (Grotius: 2017, p. 3-4)

The idea of natural law set forth by Grotius basically rested on the assumption that lawfulness or unlawfulness derived from acts that were either evidently good or evidently bad in themselves; in brief, Grotius assumed that what is right or wrong is commonsensical. This is obviously disputed. Charles Beitz (2009, p.55) argues that if human rights are natural and universal, then they must exist in conditions devoid of institutions to safeguard them, and history has demonstrated that this has not been the case, especially in the international realm. Therefore, he considers that the idea of Human Rights as natural rights is, simply put, a form of dogmatism, and that Human Rights lack a more solid theoretical foundation. In fact, approaching Human Rights without any proper contextualization can become quite a problem, given the number of conflicts and foreign interventions whose justification claims were to safeguard "Human Rights" (Beitz: 2003). This debate is not dissimilar at all to the debates on human nature set forth by Hobbes and Rousseau and might as well be a different way of presenting it. They are all competing truths to be established as universals. And this is the track that Human Rights discourse aims to follow, from the Universal Declaration and passing by the Covenants, becoming a global discourse, whichever foundation one attributes to it.

Such tendency towards universalization is directly related to dynamics of power in which human rights and its cultural background end up prevailing as the sole way of conceiving how people live and understand themselves in relation to one another. This is the criticism made for example by Gustavo Esteva when he points to the impoverishment of ways of conceiving the world and human relations and organization, in view of the expansion of a model of Western life anchored in, among other traits, the presuppositions of individuality and equality of rights. The point rests on the lack of cultural sensibility, 
respect and curiosity for other ways of conceiving entire worldviews. This is most present in intercultural encounters with groups marginalized from the West, mainly done by people who hold those work-positions because they, oddly enough, are interested in engaging with alterity. But alterity cannot be taken as a token. It is not only about more crass aspects of everyday life such as the food one eats, but about mindsets and metaphysics. It is about learning in a deeper level through the interaction and effort to understand social dynamics also through the eyes and logics of the other. There is no doubt that most human rights defenders engaging with what then becomes subaltern cultures have good intentions of reasserting people's dignity in the form of their human rights. However, remaining in their own conception of humans as bearers of rights, and understanding it as the only form of living and relating that exists is, at the very least, shallow empathy. It lacks the willingness to fully engage with others and be enchanted from the other's perspective, feeding only one's own, a process akin to colonialism.

\section{2- Individualistic Rights:}

Following, and connected to the critique of human rights and its universalist tendencies, is the critique of human rights as individualist. Such a critique is based on the understanding that humans, albeit individual entities, are not disconnected from their fellows and context. Therefore, their own value and conditions for living in freedom and dignity are not exclusive and intrinsic to them.

The issue of individualism in human rights again is not necessarily or directly related to human rights per se, but stems from the heavy influences from a Western cultural context, in which the conception of an individual is atomized and thus alienated, disconnected from his peers and context or environment, a conception that stems both from Newtonian physics and Cartesian reductionism - basically, from a substantive ontology, 
which is specific to the intellectual history of Europe but spread towards colonization. The individualism issue was already mentioned in the UNESCO Commission's work headed by Maritain ${ }^{22}$ over the circumstances of their creation and the understanding of individualsin-society.

More specifically, the most problematic underpinning of mainstream human rights discourse as individualistic is its liberal-bourgeois inspiration. It presupposes that individuals are self-sufficient in pursuing and safeguarding their interests, regardless of the social context in which they find themselves. In so doing, it overlooks the produced political realities into which we are born. As an individual, I hold autonomy to make decisions over my life. Oftentimes, however, the decisions I can make as an autonomous individual in the pursuit of a life with dignity are severely difficult or limited. Here an appraisal of life-diversity is not so much a valid dismissal of this issue but rather of inequality. At heart, diversity is not the issue. Further, this individualistic approach of human rights, based on the idea of self-sufficient and the idealtype of autonomous individuals, overlooks (on top of pre-existing produced social and political realities) that a larger number of people are more often objects of human rights than subjects themselves (Santos: 2013).

These problems become most evident with undocumented migrant minorities. Jaya Ramji-Nogales (2014) further exposes the limitations of individual-centered human rights discourse and ensuing actions by analyzing the collective of undocumented migrants. Ramji-Nogales points out that it is extremely difficult for undocumented migrants to exercise their rights while vulnerable due to not holding papers and thus are subject to deportation. Addressing this vulnerability is key for undocumented migrants to claim any sort of rights - autonomy is no good when the choices one can make in order to reunite with

\footnotetext{
${ }^{22}$ In particular the texts of Arnold Lien, Salvador Madariaga and Richard Mckeon.
} 
one's family or seek better work and life conditions (and seek legal support) challenge one to the point of eroding one's dignity.

The reality of vulnerability of many undocumented migrants exposes how certain kinds of tribulations are unequally distributed. Operating a substantive ontology and liberal-bourgeois mindset may ultimately render people self-centered, even those who lack choices other than fending for themselves without support and protection from the very institutions that are to safeguard a life with dignity, such as the State. This is the so-called self-made man fantasy. But love demands breaking away with such mindset substantive ontology and also, and especially, being committed to change the more immediate realities of others.

\section{3- Essentialism:}

The critique of Human Rights as essentialist is connected with the assumption of Human Rights being a universal standard applicable (importable) everywhere regardless of cultural specificity, even though the very study fostered by the UNESCO Commission for Human Rights Commission admonished that this was problematic. Like the critique of human rights being universalist, the critique of human rights as essentialist may also be traced back to the influences of Grotius' thought, in his pursuit of a moral grounding and justification for the respect of one's humanity and ensuing conviviality. As I have previously discussed, Grotius posited that an act was lawful or unlawful on the premise that there were pre-existing, "natural" laws that were undisputable and obvious, such as "a human has the right to live"; and his arguments over the existence of such undisputable natural laws basically arose from a negotiation between religious commandments (for instance: "god gave me life and thus I must carry on living until he does not" - and reasonable ("natural") discernment of right from wrong, for example: "taking away one's 
life is unnatural because it shortens one's natural life span, and is therefore, wrong". In this line of thought, the main meaning of one's life as human is determined before the very existence of this being, either based in a narrative of a God-given "commandment to live", or a natural, spontaneous occurrence that is apprehended by reason and thus must be respected.

This assumption of a pre-determined form of being human and understanding oneself was, however, heavily criticized by existentialist philosophers during the second half of the twentieth century. Mainly because there is no concrete evidence demonstrating that a human being naturally arises with an understanding of one's self-constitution and of what is morally right or wrong when it comes to one's own life and of others - no one is born knowing the meaning of life- and I here refer to having an innate set of morals, which is not the same as being able to empathize. In any event, that we give life this fundamental meaning actually comes from socialization, an internalized social narrative, and is reinforced by cultural habits, all of which hold strong consequences with regards to one's own freedom. And, it turns out that these aspects give life an inherent essence - a primordial set of traits. Existentialism argues that we are not only born not knowing any essence (not having them internalized), but that we can and must exercise our own freedom when it comes to our life and give ourselves its own value:

As originally defined by Simone de Beauvoir and Jean-Paul Sartre, existentialism is the ethical theory that we ought to treat the freedom at the core of human existence as intrinsically valuable and the foundation of all other values. It is grounded in a theory of what it is to be human that Sartre summarized in the slogan 'existence precedes essence' (Webber: 2008 p.4).

Despite Sartre's later rejection of his lecture titled "Existentialism is a Humanism", this work of his is usually considered the foundation of existentialist thought (Flynn: 2013). 
In this lecture, Sartre's responds to the Christian but also the communist monopoly on how to be a solidary person - on their delineating which set of behaviors and attitudes actually lead to a better world, and which are reproachable. Instead of blindly following certain well-meaning norms, Sartre aims at understanding and re-evaluating their contextual suitability and seeing whether they are indeed meeting their intentions. He sees that existentialism is a form of humanism because existentialism safeguards people's conscientious freedom of action - always accompanied by a process of understanding, realizing and responding to whether this freedom is being used for personal and collective good or not, and the challenges one faces in their sovereign path, which requires a high level of maturity. For Sartre, Christian and communist's abomination of humanity's evil potential demands a morality in order to serve as a social shield instead of granting one their own innate personal way of understanding life. Christian and communist values may be quite advanced realizations on solidarity, but this moral tone evidences a tendency for condenscension.

Existentialism thus poses a threat and critique to human rights discourse and labels it as essentialist precisely because it refuses to accept the ad nausean repetition of a narrative of one being born with rights without first understanding if claiming and demanding those rights are right (adequate) in every situation. In an existentialist perspective this absence of rights does not necessarily unleash one's potential violence, because, endowed with reasoning and responsibility, one may respond to one's own life challenges (and threats). Existentialism therefore rejects essentialism tendencies in human rights because it intends to provide a different basis over conviviality that is not premised on, quite earnestly, imposed dogma - if that is not redundant in itself. The consequences of this is that one may adopt the language of human rights and realize the core and concern of human rights discourse, but take leave of it whether necessary whenever realizing that such 
discourse may actually run counter to an actual and effective way of honoring humanity, especially when human rights as a discourse become synonymous with the imposition of certain cultural aspects and lifestyles that are simply violent in other people's eyes. I discuss this further below under "the hijacking of human dignity". Therefore, the critique of human rights as essentialist aims at safeguarding diverse ways of actually understanding and enacting human rights.

\section{4- Anthropocentrism:}

As previously mentioned in this chapter, the so-called third generation of human rights refers, among others, to the right of a clean and healthy natural environment for future generations. While the concern about the environmental changes catalyzed by human action since the industrial revolution is an important one, it is still relevant to reflect on how such a perspective positions other living beings in relation to human beings. The claim that Human Rights is anthropocentric goes beyond criticizing the very name of those rights, which puts humans on the forefront of their focus. It reflects a hierarchy in which human beings are placed above every other living being and nature becomes, thus, subject to human interest. As advanced as environmental laws are and as progressive as the human rights discourse can seem, the concern with non-human living beings is instrumental to human's well-being.

Well beyond any legalist system, the question about how one relates to one's own environment, in terms of other living beings and the natural world at large, remain an important ethical issue. Within this concern, the perspective of love poses a radical question towards one's engagement with alterity. To use a levinasian language: does the face of the other have human features like mine? Or would it be possible to overcome narcissistic 
tendencies of seeing others as oneself - as human? How could this affect, beyond positivized law, how I deal with all forms of life?

In his argument for a biocivilization, Cândido Grzybowski (2019) argues that no comprehensive understanding of Human Rights can de devoid of an understanding of human responsibility towards other forms of life and that any approach must necessarily go through an expansion of a logics of care and respect for nature - which is also at the core of perspectives such as Deep Ecology and Ecofeminism, addressed above as alternatives to a development discourse. Likewise, Cormac Cullinan argues:

legal systems must recognize that all aspects of nature are legal subjects that have inherent rights, and must uphold those rights. The legal recognition of Nature Rights both contextualizes human rights as species-specific articulation of Nature Rights since people are part of nature and creates duties on human beings and juristic persons to respect Nature Rights. (Cullinan: 2019 p. 245)

This legalist approach was integrated into Ecuador's Constitution in 2008, in the Universal Declaration of the Rights of Mother Earth in 2010 during the People's World Conference on Climate Change and the Rights of Mother Earth in Cochabamba, Bolivia (Cullinan: 2019 p. 245). However, echoing an existentialist critique towards human rights with regards to its anthropocentric and legalist approach one could ask: how can an ecocentric perspective be integrated by an autonomous person to the point of rendering a legalist approach to nature unnecessary, seeing nature for its own sake?

to discern and perhaps to practice a curious kind of thought, a way of careful reflection that no longer tears us out of the world of direct experience in order to represent it, but that binds us ever more deeply into the thick of that world. A way of thinking enacted as much by the body as by the mind, informed by the humid air and the soil and the quality of our breathing, by the intensity of our contact with the other bodies that surround (Abram: 2011 p.22) 
Remembering Thich Nhat Hanh's realization of inter-beingness discussed as an aspect of love in chapter 1, David Abram's thought resonates with another relationship between humanity and nature (if such a difference exists) and the quest for a biocentric language and mindset:

Becoming earth. Becoming animal. Becoming, in this manner, fully human. This is a book about becoming a two-legged animal, entirely a part of the animate world whose life swells within and unfolds all around us. It seeks a new way of speaking, one that enacts our interbeing with the earth rather than blinding us to it. A language that stirs a new humility in relation to other earthborn beings, whether spiders or obsidian outcrops or spruce limbs bent low by the clumped snow. A style of speech that opens our senses to the sensuous in all its multiform strangeness (Abram: 2011 p.22).

\section{5- The hijacking of Human Dignity:}

The differences in perspective presented in the UNESCO Commission were insufficient to constitute disagreement on the value of human life and the importance of human dignity. However, it is not possible to say the same about the human rights discourse that ensued over the two covenants, due to the instrumentalization of the implementation of the covenants. By 'highjacking of Human Dignity' I understand the uses of HR as a discourse to legitimate the pursuit of questionable political interests, in lieu of a genuine collective effort to foster politics that favor human dignity. "Human rights is increasingly seen as the language of a moral imperialism just as ruthless and just as self-deceived as the colonial hubris of yesteryear" says Ignatieff (2001, p.299), criticizing the convenience of adopting a universalist approach to Human Rights. The current decade's cases of the US intervention in Iraq and Libya are among the most cited representations of political and economic interests at play, and this sort of geopolitical practice has been widely and fairly accused of neocolonial and neo-imperialist. 
It is equally factual that governments facing criticism for abusing their own people's rights, even undergoing humanitarian intervention, try to shield themselves by accusing the US of being imperialist and accusing International Institutions of being subservient to questionable political interests, along with imposing Western culture and values. In Michael Ignatieff's 2001 work with the explicit title of Human Rights as Politics and Idolatry, he analyses the rejection of human rights, considering that HR would only have value whenever people agreed on its importance (with the hopes that governments reflect people's interests) - which again points to an anti-essentialist but also culturally-specific approach to human dignity. This is the reason why, even if Ignatieff thinks that the will of people are considered and thus respected in the form of human rights or other moral codes (in a way defending cultural relativism), he will nonetheless support the US burden's to be a police-state or even an empire when it comes to safeguarding themselves and their own values, as he stated in The New York Times Magazine on January $5^{\text {th }}$, 2003, claiming this to be the lesser of evils and that America's own empire came to be in a manner different from Rome, or Britain (feeding into the American exceptionalism discourse).

The problem at stake - namely the accommodation of different understandings of human dignity through conflict transformation via government action (partially expressed in the relativism versus universalism debate), raises a more difficult question on the human centered attitude necessary in order to transform conflicts by every individual and governments implied in those conflicts, devoid of cynicism and instrumentalization of political discourses. How can genuine human concern and ensuing initiatives be rightfully devised? Are the victims in alleged situations of human abuse being heard and accompanied? Is there an effective (formal or informal) system in which violence is being addressed and conflicts transformed? How much say and power do individuals hold in the higher spheres of government and policy, as to avoid being misrepresented by their own 
governments or foreign ones and safeguarding their rights and their dignity? The externalization of respect for human beings to competent superior spheres requires constant reevaluation, it requires one to actively be an agent of conflict transformation, honoring the many forms human rights take shape. In order words, how to maintain Human Rights Dignity-Centered and, effectively, human?

\section{6- Legalism \& Punishment:}

The implications of framing human dignity as a matter of rights to be legally bound, with its corresponding sanctions and punishments for those who do not respect those rights thus possibly committing a crime, raises an important concern from the perspective of love: how appropriate can punishment or compensation be in situations of human rights violations? Moreover, how can coercion be meaningful in apprehending human dignity? Is it ever possible to list every possible form of violation of human dignity and from this compiled list sentence violators or reward/compensate victims to the point of transformation? This is a fundamental reflection on conflict transformation and justice and what is deeply at stake - crime and punishment; or liberation of sorrows, opportunity to learn, and transformation from abstract and faceless identities of either victims or perpetrators into actual human beings?

A similar debate, albeit with a different shape, takes shape through the idea of fairness found in John Rawls' A Theory of Justice of 1971. Rawls did not focus on crime and punishment, as he was rather concerned with matters of injustice in the US after realizing that capital inequality, poverty, and the US police and incarceration system leave the poor and black people statistically more prone to being convicted and punished. Addressing this, Rawls explores the idea of a "veil of ignorance" that would hamper bias and apathy from others' suffering, including prejudice and indifference. The veil of 
ignorance would thus be a position to stimulate a form of engagement and empathic response, as people would have an innate understanding of fairness, of how to treat each other and lead life (Wenar: 2017; The School of Life: 2019).

If we retain Rawls approach towards justice and apply it towards human rights, then perhaps restorative justice might arise as a converging point between justice, peace studies and a perspective of love that manifests itself in the sustenance of human dignity and being human centered.

Restorative justice is a theory of justice that emphasizes repairing the harm caused by criminal behaviour. It is best accomplished through cooperative processes that include all stakeholders. This can lead to transformation of people, relationships and communities. (...) Restorative justice theory and programs have emerged over the past 35 years as an increasingly influential world-wide alternative to criminal justice practice. (Centre for Justice \& Reconciliation: 2020)

Restorative Justice has become integrated into legal practices in countries such as my own - Brazil, departing from an understanding that distributive justice hardly ever settles the actual conflict that led to recurring to justice, because it overlooks the complexities of human beings involved in conflict, that often looks not after reparation but for common understanding of harms made, reinstating mutual respect for parties involved, and creating caring, inclusive, solidary, responsible and peaceful communities (Centre for Justice \& Reconciliation: 2020).

\section{7- Human Rights or Men's Rights? A Feminist Critique:}

While human rights as a discourse aims at providing a language in which all people should be able to feel represented, it does not go unnoticed that the abstract term "human" in human rights, used to refer to both men's and women's rights, might not be as gender neutral as one would imagine, particularly by looking at its history. 
Firstly, in its very conception, particularly within the first generations of human rights, it entails a conception of humans that freely engage in public and political affairs, without much impediment, a practice that women were still fighting to have during the weaving of the covenant of civil and political rights. Catharine McKinnon states that "we are all measured by a male standard for women, a standard that is not ours" (McKinnon: 1987 p.76). This discourse has eventually led to the Convention on the Elimination of All Forms of Discrimination against Women (CEDAW), adopted in 1979 by the UN General Assembly (United Nations Entity for Gender Equality and the Empowerment of Women: 2019) although full and equal participation of women in political, civil, economic, social, and cultural life at the national, regional, and international level was recognized only in 1993 at the Vienna World Conference on Human Rights (United Nations General Assembly: 2004).

Secondly, a feminist lens considers it important to analyze how the very human rights discourse is gendered, safeguarding humans from those concerns that are traditionally conceived to be men's preoccupations, while women's concerns - such as sexual violence, gender inequality, and violence against women - have been left out:

Claims to gender equality and the idea of 'women's' human rights were premised on a critique of human rights law as adopting the 'male' sex as the standard against which all others were to be judged and conceived as a set of 'male' rights, that is, rights that are 'defined by the criterion of what men fear will happen to them' (Kapur in Emon, Ellis \& Glahn: 2012 p. 272-273)

This issue gained particular prominence after the Yugoslav Wars, the Rwandan Genocide and the Civil War in Sierra Leone, in which sexual violence, more specifically, war rape was used as a weapon, although sexual violence was not exclusive to these violent contexts. Because of the perception that women's issues become invisibilized within the gender neutral discourse of human rights, this critique remains an important irritation point to Human Rights advocates that do not "see gender". 
With its critiques of universalism, essentialism, individualism, over-legalism, gender-bias, anthropocentrism, and the misuses of the term Human Rights, the good intentions and well meaning of those who weaved the Universal Declaration of Human Rights demand a deeper engagement with the collectives they aim to support with such a declaration. Ahead I weave into this discussion Ubuntu as an approach that may attend to these concerns.

\section{8- Ubuntu/Hunhu as Human Rights Critique:}

Perhaps the most encompassing response to the notion of Human Rights, which encapsulate all the seven previous critiques, comes from Hunhu/Ubuntu - sometimes also spelled as Umuntu. Ubuntu is considered a term for humanness in the Nguni languages, derived from the proverb "umuntu ngumuntu ngabantu", commonly translated as "a person is a person through other persons". Hunhu, on its hand, is the Shona language's equivalent to Ubuntu (Gade: 2011 p.311). The term Ubuntu is considered to have correlates in many other languages spoken in Sub-Saharan Africa and, if these correlates all hold the same meaning, one might consider that Ubuntu is a perspective shared by many indigenous peoples South of the Sahara Desert (Gade, 2012 p. 486).

In his search for the earliest scholarly references to the term Ubuntu, Christian Gade listed that Ubuntu held, among others, as many as the following meanings (in chronological order of appearance): “human nature”, “humanity”, “humanism”, “humanness”, “virtue”, "goodness of nature", "the sense of common humanity", "true good fellowship and sympathy in joy and in sorrow", "the kindly simple feeling for persons as persons", "generosity", "politeness", "kindness", "benevolence and greatness of soul” (Gade: 2011 p. 307-308). 
According to Gade, although Ubuntu has appeared in writing as early as the first half of the nineteenth century (understood then as a human quality), the understanding of Ubuntu as a form of an African philosophy, an ethic, or a worldview, has only emerged in the second half of the twentieth century, in association with the decolonial processes and the change in governmental control from white Europeans colonizers to black Africans (Gade: 2011 p. 303). Of course, an African idea of humanness and of human dignity has existed before the academic and public discourse on Ubuntu, and possibly aloof to the term Ubuntu in itself, such as Julius Nyerere's ujamaa or African communalism; but Gade sees the discourse of Ubuntu as related with a larger process of unearthing African perspectives which have existed before the dark period of colonization, as a form of return to traditions (Gade: 2011 p. 304) and as a way to start anew after formal decolonization. Gade is, however, cautious about the quick and easy transformation (and, thus, change) from the understanding of noble human quality towards a philosophy and/or worldview branded "traditional African", as they might as well have served the agendas of the scholars who have tried to (re-)define the term and the agendas of those who held key governmental positions within the administration of the newly created African countries, manipulating it into an instrumental ideology.

In any event, the discourse acquired a life of its own, and Lucius T. Outlaw Jr. highlights the importance Ubuntu had in the public hearings sponsored by the Truth and Reconciliation Commission (TRC) in the country (Outlaw: 2017), so that people could revisit the atrocities committed during apartheid and still come out able to heal their wounds and carry on with their lives, for recovering a basic human nature even in the aftermath of systematized human violence.

But the question that remains is how Ubuntu can be understood as a fundamental critique of Human Rights. Leonhard Praeg (2014) reflects on this challenge by asserting 
the difficulties of separating being from belonging in Ubuntu, which accomplished by Western modernity. Praeg sees that belonging, for the West, is a feature that starts from the individual planning ways to come together as a group. And he critiques this instance by incorporating Patrick Chabal's philosophical anthropology analysis, which in Ubuntu is "a distinction between being and belonging is less clear, perhaps even absent, at the level of praxis" (Praeg: 2014 p. 35). What Praeg means is that there is no way an individual can be asserted without reference to a community, and thus one is always part of something larger and cannot be dissociated thereof. Though this perspective, there is no necessity for one to devise strategies to come together with people, as one already does belong to the group. This implies a certain way of responding to people which is without an exterior moral imperative and personal interest as intermediate, as motivator. Being in this sense is responding to the fact of belonging, which demands being dutiful and reciprocal to human interdependence. In this way, life is conceived as service to a more complex system. Therefore, in this perspective, to talk about human rights would require a continuous practice of relating.

This practice of relating is of key importance because, through relating to the individuals and communities human rights stand for, one becomes sensible to imposing foreign cultural values and the contextualiaty and validity of certain language and approaches (addressing universalism, essentialism, individualism, legalism and any misuses of Human Rights) and deals with the particularities of each person/grouping (addressing a gender bias and anthropocentrism).

\section{5- Final Reflections on Love and Human Rights:}

Twisting Rawls' concept of the veil of ignorance, perhaps the issue at stake with the discourse of human rights is precisely a different kind of veil of ignorance that covers 
part of its advocates. This veil of ignorance on the part of human rights advocates and enthusiasts, often in the guise of international institutions officers, makes them blind to the very human people they desire to protect and work on behalf of. Speaking and acting "in the name of" does not necessarily entail actual previous engagement, mutual understanding and motivation/intent. Moreover, the amount of effort it takes to summon and campaign the idea of human rights and human dignity cannot compare to the amount of focus it takes to actually engage with and celebrate human rights and human dignity in concrete human encounters, for it is on this everyday dwelling with fellow humans that conflicts will arise and demand effort in order to sustain collective respect and dignity. Human Rights for me, thus, is about the coherence between attitude and intent within every act under its banner.

The international human rights discourse has such a strong appeal precisely because not supporting human rights is often read as positioning oneself against fellow humans, and it has become an empty statement to say one defends human rights. In this chapter, however, I explored the phenomena of defending human rights as an ill-conceived manner: engaging with fellow human beings from one's own perspective alone, leaving little space for hearing others, finding common ground of understanding and exploring creative ways to celebrate unionship beyond preconceptions and bias of what society should be like and which norms it should follow just to conform to a certain standard. My critique goes in particular to the conception/abstraction of human beings embedded in international human rights discourse. This discourse conceives humans as ontologically separated entities struggling to safeguard their own existence. In this logic human beings are dissociated from their relational/community context, as empty vessels that doth need to be protected at all costs due to their fragility. In this light, the discourse on human rights becomes the guarantor for one to live well. 
Responding to such an issue, on the micro-level, love as service and participation in my fellow's struggles, in a way that does not obliterate personal differences by my own projections, allows me to see others in their full potential and willingly participate in their life, instead of acting out on abstract moral preconceptions that provide ways of acting that bypass human connection and concrete engagement in conflict transformation. On the macro-level, human agency and guidance from compassionate engagement must be present in weaving guiding policy sensitive to cultural difference. This is the example found in the debates within United Nations Commission for Human Rights. Now it bears the question about how the deriving guiding policies were instrumentalized for political interest that once again loses focus on human life at stake. This is a fundamental awareness that cannot be overlooked in all spheres of politics, understanding that being political is just a form of relating, that is, a form of belonging and participating and that every action taken is an action that has implications to the world and not only fellow human beings but other beings in this world.

Of course, this debate means not to render current legislation that offers protection to vulnerable human beings obsolete. That would be filled with irresponsibility. It is both important to understand the limitations of pure legislation as imperatives and their very reason for existence in order to explore creative, alternative forms of participating in collective life as a way to be of service to and respond to presented needs, as a personal duty. Further, it bears the question af any possible need to subvert current moral imperatives, disavowing certain ways to defend and foster of human rights that are insensitive to cultural difference and hence disrespectful of human diversity. To all this, it is no less important for one to hold accordingly (critical) knowledge on the archeology of human rights and the contemporary issues and critiques at stake. This was the effort set forth in this chapter. 
In order to be of service to peace, approaching human rights from a perspective of love will pose the fundamental challenge of opening ourselves to our own potential humanity. This can only be done through the commitment of enlarging our capability to encounter and welcome our fellows. It requires me to strip himself of all my preconceptions, of all alluring discourses I have incorporated before, in order to deal with the human being right in front of me, with any human being with whom I cross paths. This is the everyday practice of celebrating human dignity, and this is the moment where the thoughts of both Buber and Levinas merge: the real living that is done when we gaze the face of the other and engage with them. It takes thus a concrete backdrop in which I am not only within the confines of academic and policy-making discussion, or within rights implementation projects on behalf of vulnerable people, but being present, asking about and responding to others' needs. Only then it is possible to talk about human rights, and consequentially deriving renewed critical philosophical, ethical and legal frames from these concrete encounters. In the end, both our attitude and actions shall attest to our fraternity as the purpose of living. 


\section{Conclusions to Part II- Regarding Love and The Heirloom of International Studies for Peace Studies:}

\begin{abstract}
Theory - the seeing of patterns, showing the forest as well as the trees - theory can be a dew that rises from the earth and collects in the rain cloud and returns to earth over and over. But if doesn't smell of the earth, it isn't good for the earth. Abstractions severed from the doings of living people, fed back to people as slogans. (Rich: 1984 p.213-214)
\end{abstract}

My aim in this second part of this thesis was to approach and make an in-depth exploration of the constitutive perspectives of the three disciplines that comprise International Studies (International Relations, Development, and Human Rights), in an effort to gain a critical sense of the main discourses which peace studies inherited. Although the listing is non-exhaustive, in this second part I provided a certain semiotics of International Studies, highlighting which sort of events in the international arena become relevant signs, the meanings attributed to them, the relations they pose to each other, and, especially, the discourses that are made within this system and how they reinforce its logics.

In a nutshell, I have discussed the several mind-states triggered by and triggering of each International Relations Theory and the relations between one's own attitude and perspective over the world and world politics - connecting one's outlooks over the world with one's personal account of self. I discussed the fear induced by a lack of means to produce and survive (understood as private property) and the derivative paternalistic practices of social control within development as discourse, at times presented as an epochal form of care and concern for other's well-being, along with their contestations and 
alternatives. Lastly, I discussed how the intent and effort of safeguarding humanity from suffering has paved way for a comprehensive (albeit incomplete) understanding of rights, which altogether is not devoid of problems when it comes to their inter-cultural translation and the corresponding ability to accommodate difference and disagreement while sustaining respect and not compromising a sense of security.

How to address these within a peace scholarship with a loving attitude? This is the point I shall address ahead. 


\section{Part III: Towards a Peace Scholarship that Includes One's Heart}

We shall concentrate in this study mainly on the psychological and sociocultural planes of love -love as a "visible" empirical psychosocial phenomenon. Concentrating on these planes, however, we shall Always keep in mind the manifoldness of love as a whole, because without its religious, ethical, and ontological aspects we cannot truly understand a " visible" part of this cosmos, its psychosocial empirical aspects. (Pitirin Sorokin: 1954, p.14)

\section{Introduction to Part III- Towards a Peace Scholarship that Includes One's}

\section{Heart: A brief Introduction:}

In the previous part of this thesis, I have specifically examined the disciplines of International Relations, Development and Human Rights, which fall under the umbrella field area of International Studies, from which peace studies also stems and is oftentimes confused with. My objective was to point out a gap in research connecting the forms of suffering and violence discussed by International Studies, with the life-experiences, mindsets and attitudes of scholars, researchers and wokers themselves, and with the people who are objects of their research and work. In this way, it was possible to make explicit how these elements are in many ways interrelated but sometimes are overlooked. In fact, it is precisely exploring this connection that peace studies may substantially differentiate itself from international studies, and may provide more comprehensive answers to violence and suffering compared to what international studies has done thus far. It is through the 
inclusion of one's heart and capability of loving that peace studies may differentiate itself from international studies and provide a more meaningful answer to suffering and violence.

In order to explore such a connection between collective suffering and violence, and one's own suffering, it is fundamental for the peace scholar/researcher to be able to explore his/her own state of mind, intents and attitudes, along with his/her own discursive and practical positioning, if one is to provide a coherent and meaningful response both to the larger peace and conflict issues raised over International Studies and the peace and conflicts created and experienced by international studies scholars themselves. In fact, the amount of work one puts into being of service to themselves and to the world in this exploration of one's state of mind, intent, attitude, and their subsequent discursive positioning is none other than one's capability of tuning into their hearts and exercising their capability of loving.

As a matter of fact, there are three particular perspectives within International Studies that point to the importance of dealing with what stands in front of oneself and with all one's capabilities, setting the need for the epistemological turn of peace studies which requires one's ability to love. This epistemological turn, based on this ability, is the key to a relevant differentiation between peace studies and international studies. Regarding the perspectives which invite us to bring up our heart, one of these particular perspectives arise from International Relations, another from Development, and a third from Human Rights. In the last part of this thesis, I will (1) highlight the singular aspects of these three particular perspectives within IS which amount to an epistemological turn that includes one's heart and helps differentiate peace studies from international studies and (2) provide an image of what the inclusion of love as a fundamental part of peace scholarship may look like. 


\section{Chapter 6 - Peace Studies with One's Heart:}

love furnishes considerable driving force to the total power of each of the highest values of human life: to the power of truth and knowledge, of beauty, and freedom, of goodness, and happiness. Each of these end values has its own power that tangibly effects, enriches, and ennobles the life of individuals, of groups, and the course of human history. Entering as a component into each of these values, love adds to their power. (Pitirin Sorokin: 1954, p.77-78)

\section{1- Introduction:}

le philosophe (et sous ce mot, qu'on l'entende au neutre, vient aussi, naturellement, la philosophe) doit être sans doute un scientifique averti, un amateur de poèmes et un militant politique, mais qu'il doit aussi assumer que la pensée n'est jamais séparable des violentes péripéties de l'amour (Badiou: 2009 p.7)

The excerpt above is part of French philosopher Alain Badiou's opening statement in the book Éloge de l'Amour (2009), written with journalist Nicolas Truong, who invited Badiou to his Théâtre des Idées (Theater of Ideas) at the arts Festival which is traditional in the city of Avignon, France. In the excerpt, Badiou states that the philosopher must be a diligent scientist, lover of poems and political militant while always aware that his thoughts are inseparable from love's violent mishaps. What Badiou means by love's violent mishaps are the tensions and difficulties in relating with others and different perspectives (which strongly resembles Levinas' thought). Badiou poses that love is that which comes of a contingent encounter, an (oftentimes painful) event which requires one to open oneself. This opening brings about a dislocation of self into the space between one-another, in this 
space in which any point of view is decentralized and the world is simply a pulsation of life. Badiou thus considers that love is always to be made anew, as every encounter with others is a new and unique encounter, which brings about a form of radical openness.

While it is hard to agree with Badiou that love can be violent, far more often it is the lover's actions and (mis-)understandings of love that may take a violent form, rather than love in itself. It is of interest here that Badiou tasks the philosopher with being a diligent scientist. I read "scientist" as a diligent researcher (and its decurring counter part, teacher), who understands his/her very personal motivation to research and teaching and the purpose of his/her craft, through and for the engagement with oneself and others (instead of a removed, -un-implicated observer trying to learn from for the very sake of learning). This makes one aware of the fundamental attitude of being present to oneself and to otherness, to respond and be of service to an enlarged and complex world. That is an act of love, and that is the core of the critique I have made to International Studies in the previous part of this thesis: that in their many strains of abstract, theoretical conceptions about the world, international studies scholars set a world puzzle to be solved in which they themselves are never fully included - or at least not explicitly, leaving their own drives and motivations unchecked on their theoretical positioning. Further, the issue of not being in sync with oneself necessarily leads to imbalance and projections when dealing with others, which are effaced and diluted into countries, groups, and collective identities, devoid of their own singularity. And this happens to be the very foundation of the Euro-modern world: key individuals who more often than not based not only their interpersonal relations but also conceived entire foreign policy strategies on personal assumptions and interpretations of themselves and of others brought about by their own biographies, which were never discussed. The subjective world of scholars are too much of a taboo within (Euro-modern) academia, even though it ended up (ends up) influencing the whole world. 
In International Studies, there is a fundamental assumption that the world out there bears no relation to the world one (inter-)subjectively perceives or makes (anew) as daily practice. This focus, the continuum between one's subjectivity and the unfolding of their relations from the intra-personal, passing through the interpersonal all the way up to the international level, shake the foundations of the entire area of International Studies.

Meanwhile, Peace Studies has made its purpose explicit (being of service to humankind by promoting peace). From its very beginning, Peace Studies sought to discuss peace itself, instead of discussing its assumed opposite, war, like international studies did. It Breaking away with stark international analyses which do not service peace represent an incredibly important work. This peace work addressed the matter of dealing with others in a more humane way, regardless of one's personal motivation. But only a few peace studies scholars have indeed gone deeper into connecting one's intimate motivation, one's very heart, to the peace they desire to see out there, thus checking the coherence between within and without, the sustenance and homeostasis between inner and outer peace. Furthermore, few scholars have posed a critique of International Studies from this perspective.

In the end, both the attitude of not integrating individuals in their own singularity in the world of our making (typical of International Studies), and the attitude of not delving deeper into the ways one's heart and personal drives may experience and foster peace (which is generally present in peace studies), end up representing a form of lack of awareness, for either projecting wanton theoretical perspectives, or not being able to sustain from within the peace they aim to achieve.

And when one poses theoretical perspectives tinted with external and internal unawareness, which in turn become public policy and inform people, then one is both oblivious of context and of one's own wounds, making them collective. It is already a significant disservice to not see people for who they are and their potentialities, and it is 
even more problematic if one also imposes one's own issues onto others in lieu of addressing one's own and paying attention to those affected by it. This demonstrates a lack of both awareness and of responsibility, even if the hypothetical situation of not seeing people and collectivizing one's own wounds may eventually offer an opportunity for transformation. But, since love is to always to be made anew, even when it was not there, as Badiou noted, then bringing such newness requires preparation and work on a renewed attitude to transform human suffering, within the many opportunities that arise, which require one to be open, aware and present.

In this third part and last chapter of this thesis, I would like to give consideration to these three traits of love-openness, awareness, and presence - and demonstrate how each of them have been discussed in groundbreaking approaches of International Studies which, for obvious reasons, do not make up to the traditional cannon of these disciplines. My intention with this step is to make explicit how these texts contribute to a peace studies reader that derive from IS but that integrate love as its fundamental feature and skill to be honed in peace studies. I talk about openness through the selected work of Inayatullah's Autobiographic IR for International Relations. With regards to awareness, I do so through Hathaway and Boff's Tao of Transformation as Development critique. In order to discuss presence, I delve into the discussion of Ubuntu as Human Rights critique. Finally, I reflect on the potential that the peace studies classroom taps into, its teaching, and its practical orientation for students, when openness, awareness and presence are integrated.

\section{2- Openness through Naeem Inayatullah in Autobiographical IR:}

The book edited by Naeem Inayatullah titled Autobiographical IR: I, IR (2011) represents a major effort in making a different form of International Relations. I have not included Inayatullah's work as part of the third chapter of this thesis dedicated to IR theory 
simply because it escapes the cannon of traditional IR theory which are represented mainly by an assumed objective observation and the ensuing abstraction of international dynamics. Inayatullah parts ways with traditional theory when, after several International Studies Association (ISA) gatherings, he realized that more often than not, conversations outside panels about his peer's own lives seemed way more interesting than the debates taking place within the panels. Moreover, after years of dedicating himself to the study of IR and political economy, as a Pakistani from Peshawar who visited Afghanistan a couple times, and a former student of two of the most knowledgeable people on Afghanistan, Inayatullah found himself in the situation that it was his own life - not his work - that drew people's attention. This took place after the discovery of Afghanistan by US people post $9 / 11$, when people were eager to learn about the country and their people (Inayatullah also felt particularly annoyed by the suspicion that his own life was being orientalized and exotified for the proximity to the then mysterious country).

Not without difficulties of exposing himself and his life in a different form of scholarship, Autobiographical IR became thus an outlet for Inayatullah to bridge the gap between thinking and living, honoring scholars' own lives. This is an outstanding initiative from a perspective of love because it is people (ourselves), and our lives that matter after all, and dedicating much time solely to thinking about the iterations of imagined political communities may become a way of losing focus on human beings, a distraction. Granted, our theoretical perspectives are views that stem from our own life-experiences - and are thus a relevant part of ourselves to engage with; however, personal perspectives in no way can ever translate to the entire world. This is a contention against modern objectivity exhausted in debate already. Moreover, Autobiographical IR represents an effort into opening up to subjectivity. As in the preface of this work, it is stated that

Authors highlight their motives, their desires, and their wounds. By connecting their theoretical and practical engagements with their needs and wounds, and by working within 
the overlap between theory, history, and autobiography, these essays aim to increase the clarity, urgency, and meaningfulness of academic work (Inayatullah: 2001, p.6).

The effort of openness in the texts of Autobiographical IR is favored particularly by the method called "mystory" proposed by Mike Pearson, Professor of Performance Studies, Aberystwyth University, Wales. Through such a method,

the author identifies with the object of study, acknowledging affiliations and bias, and this drives the research: whilst conventional academic practice is clearly present, it is infused with personal observations and sources of lay knowledge. The method is emotional, selfreflexive and revelatory (Pearsons: 2006 p.10 as quoted in Inayatullah: 2011 p.4).

Mystory bears many similarities with the approach taken in this thesis with regard to the author's perspective as well as how I have elicited the relations between theory and author's own biographies in part II. In any event, in his methodological choice, Inayatullah points out that the reasoning behind it has to do with the fact that the fictive distance of researchers from their research-objects and texts disconnect their work from their daily life. This leads to an academic practice that becomes formal, abstruse and lacking in purpose, begetting alienation (Inayatullah: 2011 p. 6). His purpose is to avoid alienation by approximating writers to readers in a more meaningful experience for both of them (Inayatullah: 2011 p. 7). Further, he highlights how this approach reveals the uniqueness of each person and the experiences that make oneself, thus allowing for a rediscovery and a fascinating encounter with others, none other than the meaning of love that Badiou brought, which has the capacity to reveal and forge entirely new worlds.

\section{1- Conceptualizing Openness:}

Inayatullah's work therefore reveals a fundamental aspect lacking in International Studies: Openness. What I understand by openness is the fundamental capacity to be in tune with oneself, to understand and be able to recognize and eventually integrate one's 
own personal processes, challenges, and also wounds and traumas. This is an effort that deeply touches human matters and is thus a relevant issue for us all. Openness to oneself usually begets openness in others and, this inevitably leads to connection, or at the very least, an acknowledgement of connection. When we are open to each other and do hold things back, we become wholesome and a deep sense of unionship arises. To bring my rendering of love in the first chapter of this thesis, this unionship has been called brotherly love by Erich Fromm; it is expressed in Carl Rogers practice; it is the matter of the philosophy of Levinas' wonderment with the face of the other and Buber's celebration of I and Thou.

\section{3- Awareness in Hathaway and Boff's ecological consciousness in the Tao}

\section{of Liberation:}

In October 2009, a collaboration between Canadian adult educator Mark Hathaway and Brazilian theologian Leonardo Boff culminated in the publication of the award-winning book The Tao of Liberation: Exploring the Ecology of Transformation (Tao of Liberation, n.d.). Leonardo Boff is a well-known Brazilian theologian who belonged to the Order of the Franciscan Friars Minor and earned a doctorate in Philosophy and Theology from the University of Munich in 1970. Boff taught ecology, theology and spirituality in universities in Brazil and abroad for over 22 years, but his fame comes mainly from being one of the founders of what came to be known as Liberation Theology. Liberation Theology was a Freirean-influenced, socially-oriented interpretation of the Christian Gospel centered in the poor and most vulnerable (in the face of the inequalities existent Latin America), which gained momentum in the Conference of Latin American Bishops held in Medellin, Colombia, in 1968. Because of Boff's insubordination to the Vatican Orders of silencing 
his opinions, Boff ceased to be a priest and became a professor at the State University of Rio de Janeiro (Spirituality and Practice, 2019). As per his own academia.edu profile, Mark Hathaway currently holds a post-doctoral fellowship at the University of Waterloo in Canada (Hathaway: 2019), where he conducts research on the interconnections between ecology, economics, social justice, spirituality, and cosmology, teaching about cosmologies, worldviews, and adult transformative learning from his experience living in Peru and having worked with ecumenical justice work in Latin America (Tao of Liberation: n.d.).

I have placed Hathaway and Boff's work outside the formal chapter on Development and Development critique for a reason similar to why I have not attached Inayatullah's work within the International Relations chapter. While Inayatullah breaks with cannonical IR, Hathaway and Boff are not concerned much with development per se, but with the larger rationale that development derives from and implies. Nonetheless, their reflections remain relevant for any development reader:

We stand at a critical moment in Earth's history, a time when humanity must choose its future. As the world becomes increasingly interdependent and fragile, the future at once holds great peril and great promise. To move forward we must recognize that in the midst of a magnificent diversity of cultures and life forms we are one human family and one Earth community with a common destiny. We must join together to bring forth a sustainable global society founded on respect for nature, universal human rights, economic justice, and a culture of peace. Towards this end, it is imperative that we, the peoples of Earth, declare our responsibility to one another, to the greater community of life, and to future generations (Earth Charter International Secretariat: 2000, preamble)

In the Tao of Liberation, Hathaway and Boff share the perspective of and depart from the Earth Charter in the exploration of a new consciousness that is able to grasp and become an active part in an "ecology of transformation" - the complex systemic and collective interconnection between humans and the environment. For them, this new 
consciousness comes from accessing the Tao, that natural wisdom derived from the "principle of order that constitutes the common ground of the cosmos $(\ldots)$ the wisdom that lies at the very heart of the universe, encapsulating the essence of its purpose and direction" (Hathaway \& Boff: 2010: xxiii); from accessing "a reality that ultimately evades a hard and fast description but can only be intuited on a deeper level" (Hathaway \& Boff: 2010: xxiv). Nonetheless, they try to access such wisdom and reality from fields such as economics, cosmology, psychology, ecology and spirituality. Hence, liberation for them is manifested as the process through which the universe seeks to realize its own potential as it drives toward great differentiation, interiority (or self-organization), and communion. Within such as context, human individuals and societies become liberated to the extent that they: -become more diverse and complex, truly respecting and celebrating differences; - deepen the aspect of interiority and consciousness, fostering creative processes of selforganization; and

- Strengthen their bonds of community and interdependence, including their communion with the greater community of life on Earth " (Hathaway \& Boff: 2010: xxv)

Hathaway and Boff depart, thus, from the characterization-critique of a pathological and pervasive system that (1) furthers poverty and inequality, earth depletion, life poisoning by focusing on unsustainable growth and maldevelopment; (2) is subject to the rule of corporations and parasitic finances that promotes illusory wealth and lead to the monetization of life; (3) fragments and monopolizes knowledge and destroy diversity through monocultures of the mind and; (4) understands power as domination. The characteristics of such pathological system that Hathaway and Boff describe are particularly consonant with and manifest in the concept of development (development, ultimately, is but an expression of this pathology), and they critique this pathological system by articulating the ideas of none other than Arne Naess's Deep Ecology and Vandana Shiva's Ecofeminism - which I presented in chapter 4 of this thesis as possible responses from the heart to the concept development. 
Of course, Hathaway and Boff's argument is an intellectual observation on the state of the world in the face of the possibility of human extinction, that derives from their Christian background and idea of salvation. There is a fundamental contradiction there because if Tao is that principle of order of the universe, then Earth and humanity's current state is a legitimate part of the Tao; yet, through this very logic also their critical observation, their consciousness, is a part of the Tao towards transformation. Therefore, through their own reflections on the Earth's current crisis, one can only expect that the Tao is working through them in its constant movement, that they are being an active part in this transformation. This "working through" is a key element here, because it requires an awareness of the Tao, which Hathaway and Boff call liberation. They illustrate such ideas with the Zen Buddhism concept of satori: "a radical breakthrough that enables a person to apprehend reality directly" (Hathaway \& Boff: 2010: 292). Through satori one is able to grasp the implications of non-duality.

According to Hathaway and Boff, such awareness on non-duality or the integration of oneself with the Tao, manifests in two ways. With regards to the inner direction, it leads to a deepening of subjectivity, where we "strive to enhance life-giving expressions of creativity" (Hathaway \& Boff: 2010: 292). At the same time, in the outer direction, it leads to a "deepening communion and relationality (...) moving toward more complex relationships and broadening our sense of identification with other beings, that is, widening the circles of our compassion" (Hathaway \& Boff: 2010: 292). Ultimately, awareness deepens and also broadens communion and provides a kind of ethics-aesthetics of care through sensitivity. Awareness recognizes alterity as equal uniqueness, and through caring about this equal uniqueness it fosters a loving relationality, attentive to vital processes, giving one's life a sense of purpose. 


\section{1- Conceptualizing Awareness:}

I propose understanding openness as process that requires a first venture into the self and, in so doing, exploring vulnerability to then open up to our own peers. Meanwhile, I understand awareness as the process of enlarging this initial openness to kin. Awareness is the human process of departing from an anthropocentric to an eco- and bio-centric consciousness which is sensitive to the entire dynamics of Earth as a living system and how each element is affected by our own actions. In this consciousness, we realize that not only are we a part of nature as a whole living system, but also that, as such, we must respond to the aching no-return levels of pollution and enthropic climate change caused by human actions, which is threatening a great number of living species, including our own. Awareness, as such, is both a form of sensitivity and intellect in order to grasp the dynamics at large occurring on this planet. Without a doubt, this demands a complete change within the entire mindset we inherit from fear-driven, ego-centric mainstream economics and its derivative mal-development. This awareness is possible with my original conceptualization of love in the first part of this thesis through the ideas of inter-being of Thich Nhat-Hanh, the gospel of Francis of Assissi and Levinasian thought, though Levinas originally did not refer to alterity beyond the human face.

\section{4- Presence through Ubuntu/Hunhu as Human Rights Critique:}

In chapter 5, I wove Ubuntu as a critique of International Human Rights, in which an Ubuntu mindset is one that does not easily detach being from belonging. That is, human beings are not thought of as individuals who stand on their own and negotiate the terms in which they relate as a larger group/community, but human beings are recognized by and due to belonging to and being a part of a location, as in the place they live, their ancestors, 
their community and thus always respond to that. This begets a form of relating and engagement that is non-negotiable - and quite existential and humanistic. While Human Rights focus on the rights one individual holds and demands - much like how one negotiates his relation to the world (demanding from others), Ubuntu will focus on the duties of taking part, being present for and participating in one's community and or in fellows' struggles. In this way Ubuntu recognizes and honors human dignity, without necessarily recurring to demanding and defending one's rights. This demand and defense of one's rights has been championed within International Human Rights discourse with a strong moralist and righteous tone. Ubuntu is more so about one's responsibility in preserving the personal and collective dignity. It is about unconditionally relating, which requires a lot of presence of oneself. But the question that remains is how Ubuntu, as a critique of Human Rights, is connected with the idea of love.

Leonhard Praeg, in his philosophical reflections on Ubuntu admonishes that to assume Ubuntu as a manifestation of love or as compassion is worrisome

because its [love's] vacuity and sentimentality are achieved through the exclusion of everything substantial, including its constitutive violence and counter-hegemonic (and therefore conflictual, revolutionary, confrontational, or violent) insistence on an expanded understanding of justice that could enable us, under certain conditions and in certain circumstances, to prioritize collective goods over individual rights (Praeg: 2014 p. 267).

Praeg's basic concern resides in the disservice that a shallow or ill-conceived understanding of Ubuntu may pose to itself as a political praxis responding to (in)justice; whether or not Ubuntu could be legally considered as jurisprudence; if it is indeed a genuine African worldview in the light of African history (histories) and their relations to the West; and how and why it was brought up to matter nowadays. This is a fair point in relation to his focus of politically thinking Africa and its current place since the past five or six centuries; however, Praeg's focus on the political outcome of "using" Ubuntu omits the 
fact that to be imbued with an unconditionally compassionate spirit is a key aspect for human beings to care about or suitably address human conflicts in the first place. Furthermore, this spirit emerges not as sentimentality and (guilt-induced) duty but as compassionate service, as altruistic presence and participation in the conflicts we are faced with in life and even in the quest for justice. Without a doubt that is relevant for Africa, for thinking about Africa, and also, everywhere else. I have no doubt that such compassion calls for a form of (political) action. In the first part of this thesis, that is exactly the love drive present in the work of Paulo Freire, of bell hooks and of Gianni Vattimo.

Also, in Praeg's reflection there is no further explanation of what love would mean, though he considers that mixing Ubuntu as love may render Ubuntu as pure sentimentality. And he considers sentimentality as the opposite of committed and unconditional service. In Praeg's defense, Reginald M. J. Oduor, in his review of Report on Ubuntu (2014), will come to the conclusion that for Praeg Ubuntu is "not humanism as an autonomous ideology or philosophy to rival Western political and philosophical forms, but rather the sustained praxis of humanizing" (Oduor: 2014 p.80). I can follow and support that understanding as a form of being present, giving oneself for the other. Contrary to Praeg's views, for me, that is one of the keys aspect of love I highlight specifically from Ubuntu. Plus, this understanding is indeed relevant within Praeg's characterization of Western politics as the instrumentalization and fashioning of one's life according to an undisputed moral codex in one's own individual benefit, often justified by good intent in lieu of the very awareness of collective belonging and responsibility that Ubuntu presupposes, a point in which we coincide.

In sum, I take Ubuntu as an unconditional form of relating with fellow human beings. As such, it is not disciplined by the way I think about and conceive others, which is often the case of Human Rights discourse. Ubuntu is thus an engaged form of living with 
others because we do not have a choice to do otherwise. It is different from Human Rights because this does not require personal motivation. It is a simple fact beyond choice. Nothing in it forces me to fall prey to the Human Rights discourse's bureaucratization of human dignity, which tells me how to best act when and where. Ubuntu stands in no opposition to Human Rights and any other form of promoting human dignity, but it fundamentally challenges the moralistic grounds of Human Rights in its conception, which is so prone to violence, as it hampers me from encountering people and relating to them as they really are and come. Human Rights, as a concept that intermediates my relation to others, creates doubts of my own and others' full potential and openness to get together and creatively explore how to transform our shared problems. Ubuntu, on the other hand, reassures this state of certainty that we occupy a place in life, that we are present to it regardless of how challenging it is. This is a fundamental aspect of love to me. Of course, in my loving engagement with others, there may come a time in which good knowledge of Human Rights comes at hand. Thus, it will require appropriate preparation and caution.

\section{1- Conceptualizing Presence:}

Ubuntu's ontology offers evidence to a form of being in this world in which it is impossible not to relate, as the realization of self only comes in, with, and through others. Even not responding to others is in itself a form of relating: it is relating while rejecting interaction, which requires awareness and bears it own consequences. While not responding and interacting may as well be a legitimate answer in many cases, in for example, refusing to partake in any given form violence, I take peace work to be a form of relating while consciously responding to life matters - even violence - in ways that can be transformative and dimish human suffering. It is precisely this which I understand as presence, this act of being present, available, responding to matters and conflicts that happen around us near 
and far. Presence, as such, becomes a form of compassionate living. Presence thus becomes political because it is a form of relating to others in their (our) struggles - and seeking transformation. Bringing out the conceptualizations of love in the first chapter, it becomes evident that the works of Paulo Freire, bell hooks and Anzaldúa stand out as a way of addressing longstanding questions of inequality and, thus, of being present.

\section{5- Theme-Centered Interaction: Openness, Awareness \& Presence Integrated into Peace Studies:}

At this point I would like to refer to Theme-Centered Interaction (TCI) as a tool to give evidence and support to the benefits - for the lack of a better word - of integrating openness, awareness and presence into peace studies. TCI was created by Ruth Cohn who came from an upper class Judeo-Christian family whose thinking she represented in a secularized way in her basic humanistic stance. She transformed her existential experiences (persecution, emigration) into the hope of supporting humane action in all areas of society by strengthening self-confidence combined with a vital system of values. She studied Psychoanalysis (specifically S. Freud, H.S. Sullivan, A.Adler) in Zürich; she was philosophically influenced by the optimistic, American brand of Existentialism. Additional impulses came from reform pedagogy and body therapy (...) [though] [s] he distanced herself from exclusive individual treatment, moving to a democratic pedagogic approach. (The Ruth Cohn Institute for TCI - international: 2020).

Cohn's work has gained a distinguished place within humanistic psychology. However, Cohn considered that psychoanalysis only addressed single patients at a time and lacked a more collective stance on psychology. At the same time, the confinement of classrooms only intellectualized rather than promoted a vibrating form of learning that was in synch with life. According to Jochen Spielmann,

TCI is a comprehensive, holistic action concept that has the goal of shaping situations in which humans interact, work, live, and learn together such that they consciously experience each other as humane and humanizing. The focus lies on taking action in groups, teams, 
and organizations. TCI represents a differentiated method of observing situations as well as controlling and accompanying social processes. (...) The theoretical basis lies in the four-factor model of TCI, which says that the processes and interactions active in social situations and living learning situations can be described by four different factors: (1) the I - every individual, (2) the $\mathrm{We}$ - the interaction among those involved, (3) the It - the cause at hand, the contents, the tasks, the goals that brought everyone together, and (4) the Globe - the circumstances and conditions under which group actions take place. One special characteristic of TCI lies in its distilling the breadth of social situations down to these four factors,making them manageable. The four-factor model is well suited for interpreting and understanding situations. In addition, it helps when developing concrete action strategies (Spielmann: 2014 p.14-15).

TCI has been graphically represented in the following way:

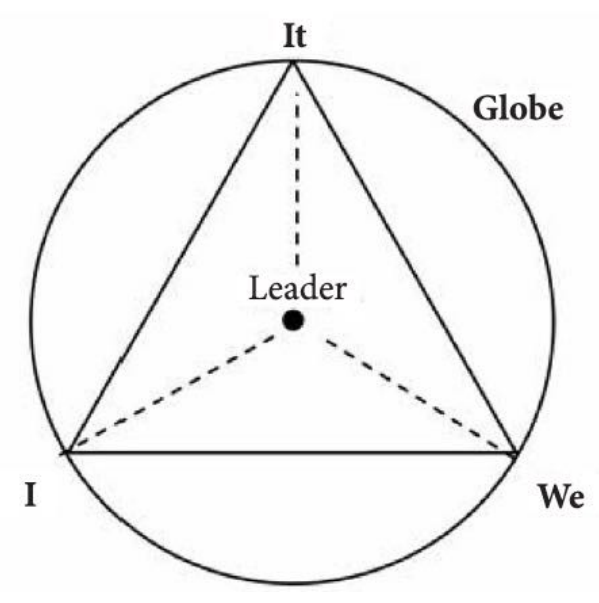

Figure 2: (The four-factor model of TCI source: Spielmann: 2014 p.15)

As an approach for interpreting situations in which all aspects of those situations are given its rightful consideration, the TCI model proves helpful in providing evidence to the imbalanced relational aspect of International Studies. Equally, it can demonstrate how Openness, Awareness and Presence work as possible answers to this issue for a more encompassing peace studies. Therefore, in the following section, I provide brief TCI readings of International Relations, Development, Human Rights and of the combination of Openness, Awareness and Presence. 


\section{1- The TCI of International Relations:}

As evidenced in chapter three, with the exception of a few theoretical approaches such as feminism in IR, International Relations heavily focuses on the topic of war and violence (the "it" of TCI), which takes place in the international sphere (the "globe" of TCI). The personal and interpersonal dimensions are often effaced from IR, which often comes in the form of critiques of this discipline having little to no affect to human agency. This provides an imbalance because according to TCI, the "I" and the "we" elements are lacking. Inayatullah's groundbreaking text, and especially the openness that I derive from it, serve as a rebalancing of IR. The idea of openness reinstates the "I" of TCI within International Relations and offers a way of making international relations recognize the vulnerable individual. In turn, this promotes an equal openness in others, thus fueling connection towards a collective (the "we" of TCI).

\section{2- The TCI of Development:}

As evidenced in chapter 4, the scarcity mindset from which economics derive, which is the main cog in development thinking, is manifested in an ego riddled with fear of lack and need for growth/acumulation. In TCI terms, this provides a model with a pathologically conceived "I" and an obsession with unsustainable goals (the it of development: infinite growth). However, the awareness towards and derived from an ecological way of living and caring for other living beings derived from the work of Hathaway and Boff, along with the tenets of deep ecology, buen-vivir and ecofeminism, draw our attention to both the "we" and the "globe" aspects of the TCI in the hopes of redressing this pathological "I" and unfeasible "it". 


\section{3- The TCI of Human Rights:}

As evidenced in chapter five, mainstream human rights, in its over-individualistic and essentialist aspects point to a problematic conception of being human which, in TCI terms, lead to an unbalanced dynamic within the four factor model because it starts from an overemphasis on the "I". On top of it, the derivative cruzade of globalizing such Human Rights discourse (basically projecting it onto the "globe" of TCI) has been a contested project. On the other hand, presence, derived from the relational ontology of Ubuntu, points towards the collective dimension of being human and consciously responding to others (the "we" of TCI), while framing the "it" of TCI as a life of service to humanity.

\section{4- The TCI of Openness, Awareness and Presence:}

In points 5.1 to $5.3 \mathrm{I}$ have used the model of TCI in order to render visible how openness, awareness and presence serve as ways to rebalance the disciplines of International Studies for peace (studies). At the same time, these 3 aspects of love may function themselves as important elements to a balanced TCI of a peace scholarship. If we take peace to the the "it" of the TCI model, openness is a way of checking the "I" and its own conception within the equation. Awareness, in itself, helps us being mindful of the dynamics at large within the "globe". Last but not least, presence, being present for others, necessarily demands keeping a "we" in check. 


\section{6- Outcomes of integrating Openness, Awareness and Presence into Peace}

\section{Studies:}

In the following points (6.1 and 6.2), I would like to continue discussing the integration of the aspects of love previously highlighted (openness, awareness and presence) both for the peace scholar himself and for their consequential work as researchers and teachers, without making use of the TCI model. For the discussion of transformation and attitude of the peace scholar individual, I resort to the ideas of Chögyam Trungpa Rinpoche, who was a Tibetan lama of the Vajrayana Buddhism school, founder of Naropa University. For the discussion of the peace scholar's researching and teaching international peace studies, I resort to the ideas of Africana Philosophy scholar Lewis Gordon.

\section{1- A New Peace Scholar:}

In chapter four, I discussed how many theoretical standpoints within IR are tinted with personal bias and nonetheless turn into policy, evidencing that personal views may end up posing a significant effect on people's lives. It takes a brief look into the speeches inciting hatred made by Brazilian Minister of Foreign Affairs, Ernesto Araújo, under Bolsonaro's government in order to understand how this has been impacting the relations, for instance, with other countries and individuals - such as the Venezuelans at the border between both countries. Being cautious of intelectual standpoints tinted by personal bias is a necessity, particularly if we would like to diminish the (negative) external effects of our feelings, thoughts and attitudes. When we start grasping the way we affect the world around us, it becomes immediately important to take a look inwards at ourselves and inquire about our share, our personal responsibility over what we foster. From such an inward gaze towards oneself, the point it is not to detect, reject or hide our confusion and with that 
assume to have become healed and have acquired inmunity to faults. Chögyam Trungpa would call that a form of spiritual materialism (Trungpa: 2001, 2002), which arrogantly assumes we become ever healed and eventually perfect, when in an ever-changing world we always fall ill and confused again. It is about recognizing our imperfect condition and, with diligence and effort, continuously working on it, making an effort to change.

The point Trungpa tries to make in Cutting Through Spiritual Materialism (2002) is to turn no provisional and temporary answers of ourselves and of the world in the shape of final theories and explanatory worldviews, and instead cherish and take responsibility for this continuous quest of seeking provisional answers to the issues the world faces. In other words, in spite of any future realization of our inadequacy and its subsequent sorrows, we must remain in dialogue to reach any contingent understanding that later can be transformed (along with ourselves). We eventually come to understand the importance of changing, regardless of how hard it becomes, when we make ourselves open to being of service to others and thus taking responsibility for the way we relate to everything. Only in this process we exercise compassion for others because we consciously dare to know firsthand the difficulties of living. It is in this recognition of our collective struggle and yet proneness to support each other that we see love flourish. This act of recognition is nothing more than encounter and connection and openness and presence. It does not require anything in return or any compensation for the hardships that come along with it. It is compassionate, because it demands nothing in return. Here lies the golden aspect of the peace scholar's attitude: on top of a rigorous attention to content brought into classroom, the most effective, and yet subtle teaching he/she provides, is his/her own observable attitude, demonstrating that what he/she is doing and who he/she is dealing with are the most precious things he/she has ever encountered, and make everything in their power to honor that. 
The funny aspect of this attitude is that, once it is there, there is no fuss to be made about it. It is an ordinary and unspectacular form of loving, and no miracle is manifest. Furthermore, Trungpa (2001) considers that the observation of this attitude gives us a glimpse of human basic goodness. By attuning into our human basic goodness, we become aware of the intrinsic beauty pertaining to all things, we become tender to the world and we appreciate it more vividly, in all its contrasts. Such a state of appreciation requires us to stand a little while with our thoughts, feelings and actions and observe them, meditate on them and consider how they will place us in the world. Sakyong Mipham Rinpoche, the son of Trungpa Rinponche, points out that his father's message was that we as humans need to

"contemplate and think about how we feel about ourselves, and that notion of self-worth. (...) how we regard ourselves is pivotal in terms of literally how our day unfolds to the scope of our whole life. (...) that that feeling that we all have at a personal nondescribable way, has incredible social ramifications. (...) [that] a society can be based on the notion of human worthiness" (Sakyong Mipham, 2012).

Thus, with tenderness and determination, we start working on what we bring into the world. Within Peace Studies, this applies especially to the way we relate to peers whenever we discuss the theoretical standpoints of International Studies which we inherited in peace studies (through frames that highlight their historical and contextual limitation: their inadequacy).

\section{2- The object of the Peace Scholar:}

Now regarding the consequences of the peace scholars attitude in their own work, I would like to do so through Lewis R. Gordon's argumentation in his book titled Disciplinary Decadence: Living Thought in Trying Times published in 2006. Lewis Gordon is known for his contribution to philosophical debate through Africana Philosophy and the 
matters of racism within the historiography of Modern Euro Western thought, as a means to acknowledge black people's existence and experience to humankind, when so much of their humanity was/is denied in colonial history and through coloniality. Gordon's work is important for this section because he gives his own very clear example of what a love scholarship can be.

In Disciplinary Decadence, Gordon addresses what he considers a set of decaying tendencies in the study of human beings, which I read as hampering us from exercising love as openness, awareness and presence. Gordon considers that the decaying tendencies have been of three types: first, a retreat and subjection to natural sciences; second, a retreat into historicism; and third, a retreat into language. Regarding the retreat into the natural sciences, Gordon notes the moral imperative of empirical evidence to validate knowing, which in a way relates to the second retreat, into history, that brings the possibility of an ultimate appeal to concrete facts, even if facts are interpreted archives of documented events, which raises the reflection whether evidence to facts is in itself factual and thus has any validity. The third retreat, into language, is related to the need of mining new and more accurate meanings and creation of explanatory concepts and categories, through Derridien deconstruction and Foucaultian archaeology and genealogy. Gordon considers that the decline in appointing evidence and communicating experience paves way into "practices of asserted beliefs" (Gordon: 2006, p.1-2) which are hermetic. When hermetic beliefs are asserted beyond those who initially believed in them, they assume the bizarre characteristics of being eternal, immutable and closed to encounter and to transformation, giving the impression of permanence and stability. That is how contemporary scholarship starts to become a place devoid of the love attitude that Trungpa has highlighted. However, Gordon does not take beliefs as existing before subjects believe in them because neither society nor living systems can go on forever. 
"everything living must die, and all living things go through processes before they die. Such a process is decay. [...] Although it has correlates in biological notions, this sense of life and death transcends the biological in that it pertains, as well, to ideas. It is thus not a naturalism, since even that notion is a form of idea, but the basis through which even its own notions come in and go out of being" (Gordon: 2006 p.2-3).

If we think of academic disciplines as knowledge-producing models that offer interpretations of given realities (which are ever changing), and that humans come to terms with and sustain those models (Gordon: 2006, p.4), then disciplines should not be immune to decadence. Thus, disciplinary decadence is the attitude of hermetically ontologizing and reifying disciplines as if they always existed, will always be and will never die or change, in lieu of accepting transformation as a continuous process.

Through Foucault, Gordon points out the awareness of the artificially-induced authority of disciplines as the foci of specialized knowledge. He examines the power they exhibit and calls for courageous acts of defiance, of questioning, thinking and acting as a practice of unsubmission and freedom. When hermeticism within disciplines condemns open thinking and free and creative acting, it locks us into our own personal, subjective prison (2006, p.6), as a way of silencing difference and suffocating transformation and reinforcing disciplinary stability and perpetuation. In other words, this hermeticism brings about decadence. Gordon, however, considers that through the phenomenological reflection and its intersubjective dimension, one becomes able to courageously engage with disciplinary decadence, especially when any appeal to evidence is futile. This intersubjective opening of phenomenological reflection is a radical activity for Gordon because it resists a world in which reality is hyper-determined by disciplinary decadence, and calls for engaging with those realities which come out of reflecting on thoughts and thinkers all together (2006, p.8) - to which I would also add the reflection on feelings. 
Gordon's thought in Disciplinary Decadence is an immediate challenge to the intellectual production of International Studies as the grand source for peace studies, to the point in which it is fair to ask if it is not the case to let it go on its own decadence, so that the idea(s) of peace(s) can actually be made anew. In this vein, it is fair to point to IS as a temporal mindset, but it is not necessary to carry on reproducing it. As Gordon explains, however, the challenge, of course, lies in the everyday of academia when universities and research institutes need to devise managerial tactics of survival by quantifying intellectual productivity and regurgitate systematized knowledge to students, which in turn are assessed on their capability of regurgitating the same knowledge over again. To the issue of letting IS go and thinking peace anew, if one follows Gordon's proposal of phenomenological reflection, then love becomes an obvious and fundamental aspect of this discipline, as phenomenological reflection cannot be carried out without the attitudes of openness, awareness and presence/participation. To the second issue revolving around academia, Gordon does not ignore that there are a few places and people who

keep sight of the value of knowledge in the long, unfolding history of humankind. And, in sufficient cases, they manage to convey the beauty and preciousness of such gifts of possibility to those who study with them. They remind us of there being a greater purpose to the art of thinking. They courageously surpass impositions of decay with generous offerings of living thought (Gordon: 2006 p.11).

As such, the work that a peace scholar does both on the self and over critically assessing the contextual relevance of ideas related to peace, through love and the heart, is a mean of being at service for the collective and, as such, emphasizes the relational aspect between my own research, teaching, facilitation, transformation and being in the world and others. In continuation, thus, I would like to reflect on how these have taken place in my own peace studies scholarship over research and teaching. 


\section{7- A more encompassing peace scholarship:}

After the working definition of love and how it has been addressed within peace studies, this thesis has been a critical journey into the curriculum that Peace Studies inherits from International Studies to realize how many of these theoretical perspectives and discourses are partially motivated by world events and significantly influenced by one's ability to grasp and interpret world events. Therefore, they say as much about the world events themselves as they say about the scholars proposing their interpretations on these events, what they highlight, and the perspective they share - and often how some interpretations are replicated by fellows, due to similar shared experiences, resonance, mirroring and projection.

Over time, it became clear to me that what drove me to engage with perspectives within International Studies was not only to understand international studies and matters of peace and conflict, but also and particularly to get close to the scholars proposing them and understand their personal drives and motivations through their written texts and biography. I was thus engaging with the scholarly outcomes of their thought in order to engage with them as individuals; however, those are different things, even theories and ideas remain as a gateway to engage with people and need to remain included: someone's thought is a part of this person but it is not all the person is.

As such, if I really am to discuss peace in a holistic manner, it will demand a greater deal of effort to work with a whole lot more than just ideas, and will eventually include a human dimension composed of feelings, wounds, desires - interpersonal conflicts and lots of aspects that traditionally are considered personal and private matters and as such do not enter the realm of "professionally" discussing politics. And this is precisely why love is an important element to incorporate into peace studies, because reaching out and being of 
service to others requires one to go further than comfortable and limited scholarly professionalism.

In the process I mention above, I have come to devise three relevant aspects of bringing mind and heart together: openness, awareness and presence. The first aspect corresponds to a reading I make of a critique of International Relations; the second aspect corresponds to a reading I make of a critique of Development; and the third aspect corresponds to a reading I make of a critique of Human Rights.

These three aspects serve as orientation points which might not necessarily bring about a grand and novel "theoretical" perspective in peace studies or change the curriculum inherited from International Studies much, but they certainly provide a way to engage with others which makes scholarly relations (and any sort of encounter) whole in quality and focus, taking people into account in their fullness: their scholarly production and their own selves. That is because bringing about openess, awareness and presence actually provide a fundamental pedagogical feature for peace studies: understanding itself not as the locus to assimilate, re-tailor, recycle or reject grand narratives about the world out there as International Studies does, but rather to understand peace studies as the locus for creating new forms of relating and ensuing narratives towards collective transformation of preexisting situations of violence. As such, love in peace studies highlights the relational aspect of the discipline, in how we can contribute to peace and conflict transformation through one's own research, teaching, facilitation and being in the world.

Below, I map out aspects that bring evidence and support to this claim.

\section{1 - Genuine Interest with Martínez Guzmán:}

As stated in chapter two, Martínez Guzmán understood philosophy as the wisdom acquired from a deep admiration, marvel and curiosity for the world and desire to engage 
with those around us. His curiosity about the world and about human relations allowed him to see how fear and rejection are big sources of conflicts and violence and tragically reveal our frailty. Out of this place of frailty comes his wisdom, and the entire foundation of his particular "realism," which is the search for ways so that we can relate to each other in peaceful and nurturing manners and address our feelings and affections in nonviolent ways to dimish suffering.

In this way, Martínez Guzmán's philosophy reasserts the relational aspect of a peace scholarship, that in turn constantly needs feedback, dialogue, and a deep effort to promote understanding. Promoting understanding and dimishing suffering are none other than two aspects of love for Buddhism, as expressed by Thich Nhat Hanh as maitri (loving-kindness) and karuna (compassionate understanding). Therefore, a more encompassing peace scholarship needs to clearly understand how to continuously derive wisdom from being dialogue and relating, and become critical of any contingent answers. Martínez Guzmán’s openness to dialogue is a key aspect that will unfold into other aspects of a more encompassing peace scholarship discussed ahead.

\section{2- Curle's Befriending:}

At this point, it becomes important to bring back Adam Curle's visionary perspective in peace studies, as he may have left a fundamental pedagogical tool for the peace studies classroom. Here, I highlight a lecture Curle gave at the Essex Hall in London on April 1977 under the title Peace and Love: The Violin and the Oboe, as reproduced in Tom Woodhouse and John Paul Lederach's book Adam Curle: Radical PeaceMaker (2016), which pays tribute to Curle's legacy.

It might have been expected that a lecture by someone holding a chair in peace studies would sagely analyse the global situation, suggest policies for the United Nations and our 
own government, denounce violence, propose panaceas for Northern Ireland and South Africa, and so on. Now, although I have not withdrawn from outward action I realize that the human being I am determines the value and effect of what I do; and that what I am is a function of my capacity to give and receive love, to experience peace (Woodhouse \& Lederach: 2016 p. 200-201).

With the remark above, Curle sums up the essential aspect of shifting International Studies to Peace: that the transformation of major violence addressed in International Studies requires an engagement all the way from a personal, human level until high echelons of politics. In my view, this engagement can only become meaningful when filled with openness, awareness and presence. Lederach explains that Curle addresses any manifestation of hostility with a compassionate attitude that approximated him to the sources of hostility, deeply knowing that intimacy and friendship facilitate mutual understanding and foster transformation in the hopes that this is a small step into dissolving violence and hostility. Curle would call such lost art of conciliation befriending. The idea of befriending encompasses care, concern, honesty and commitment; and befriending never is used instrumentally to reach ulterior purposes - no matter how noble these purposes are; befriending is the plain exercise of seeking mutual humanity, and of re-humanizing individuals (Woodhouse \& Lederach: 2016 p. 226-227). Befriending assumes that disagreement with someone's thought does not call for confusing someone with their thoughts. Furthermore, disagreement does not imply rejection and its constitutive violence, which would run counter to the unconditional engagement of befriending.

At the core of the idea of befriending, however, we find not so much final answers or propositions on what composes a new peace studies curriculum (especially regarding the legacy of International Studies), but rather the sort of soft skills and competencies that allow students to critically engage with the world of theories and ideas and with the conflicts they face in a peaceful manner. Curle would balance this out by relaying reflections from his 
experience dealing with all kinds of people and their ideas, learning by engagement. Of course, this brings about the need for the peace researcher to open up to the messiness of interacting with his peer, instead of remaining as a removed analyst of fellow's scholarship. (Woodhouse \& Lederach: 2016 p. 228).

\section{3 - Comin's Care Ethics into a Caring Teaching:}

According to Comins, an ethics of care manifests itself usually as tenderness for others; appreciation, recognition and support of life in all its forms (Comins: 2009, p.8286). Yet, Comins notes that this attitude has been ignored by most scientific disciplines including the human and social sciences (Comins: 2009, p.82). The problem that Comins evidences is that traditional humanities and social sciences have lost focus on a nurturing approach that is paramount to actually reaching the purpose of creating supportive and inclusive societies.

Comins' thought echoes what Erich Fromm considered as motherly love, which is regarded as an unconditional support of individuals in their own paths. As a community of peace students and aspiring scholars, care ethics becomes an important element of a more ecompassing peace scholarship because caring becomes a way of being supportive to anyone's learning and researching process. Whether I am a student or a scholar, whenever I am taken in consideration and cared for, I sense a deep feeling of worthiness, and knowing my worth and the worth of others I can realize how a nurturing and inclusive society can start taking shape - even if my ideas are absolutely questionable and deserve to be objected to. Care ethics thus is a form of presence - of being present to support others. 


\section{4 - A Rogerian approach to Research:}

In 1957, Rogers stated that in relationship to a client, a therapist should act based on three tenets: congruence, empathy and acceptance. Congruence meaning being authentic and earnest to one's earnest feelings and points of view; empathy as a capacity to understand the feelings and points of view of the client; and, finally, acceptance as unconditional caring for the client, regardless of different points of view between them.

Rogers' insight over therapy is not so different from a supportive environment from which people involved are able to do research and present their findings and believe in themselves and their potential.

\section{5 - Koppensteiner's Elicitive Facilitation:}

To be able to sustain an open and geuine interest as Martínez Guzmán proposes, to hold a caring attitute as Comins advocates and being congruent to oneself as Rogers requires, it takes a deep level of commitment and of self-work as teachers and researchers. This brings us to Koppensteiner's understanding of elicitive facilitation. As senior lecturer at the Unit for Peace and Conflict Studies and former program coordinator of the MA Program for Peace Studies at the University of Innsbruck, in his work on transrational methods of peace research, Norbert Koppensteiner considers

the researcher as a (re)source that can be creatively tapped during the research process $(\ldots)$ looking for an affirmative methodology and practice of research that includes and balances the necessary critical positioning as regards the researcher and her engagement with the topic and research participants (...) carried by the conviction that research can be much more than the dry and distanced gathering of knowledge or the critical examination of one's own biases and imbalances. (Koppensteiner: 2018, p.60)

Envisioning a research practice that is experiential through the exploration of topics through his body, his heart, his mind and his intuition, Koppensteiner sees research as a 
holistic process of transformation which touches on all levels of his being, in lieu of a mere informational gain. Koppensteiner sees peace studies inadequately captured by approaches that only intellectualize and alienates us from lived experience. Thus, his approach to research touches intrapersonal, interpersonal and transpersonal dimensions of being, yoking a deeper understanding and, above all, experience of peace ((Koppensteiner: 2018, p.60).

Koppensteiner understands research as a process that contributes both to collective and personal unfolding together, through a systematized and creative inquiry into a topic, which, in a transrational perspective (see chapter two), implies that research subjects become research participants, and hence are all implicated in the research process and are all relationally involved (Koppensteiner: 2018, p.66). Koppensteiner considers that this calls for an ethical stance in which the researcher has to be open, aware and actively on the lookout to welcome multiplicity in the research, while holding the space and its focus, which altogether is also known as facilitating. The core of facilitating means sustaining an atmosphere and inviting attitudes that catalyze focused engagement over collective processes of transformation. I infer that this cannot be done without the three tenets of love which I highlighted from International Studies in this chapter: openness, awareness and presence.

Openness, awareness and presence can be especially challenging when we come to deal with a fundamental part of being human: our shadow aspects. Peace studies indeed is also about violence, armed conflict, war, torture, abuse and pain; and "to exist is to partake" says Koppensteiner $(2018$, p.64). Therefore, if we partake, we cannot ignore our shadow aspects. Koppensteiner notes, however, that we can engage with them so as to transform them, out of a place of compassion and genuine desire to alleviate suffering. Likewise, on a personal level, eventually we have to deal with our cruelest judges - our very own selves 
- with a compassionate outlook (Koppensteiner: 2018, p.67) if we want to exercise that caring ethics that Comins calls for. Due to the challenging nature of engaging with the shadow, these considerations show that bringing love into peace studies and facilitation is a fundamentally risky business, as there are no guarantees over a secure outcome and yet, there is nothing closer to a real human encounter than that.

Going further into the necessary caution one has to make over approaching peace studies through love as the main quality of anahata, the heart chakra, Koppensteiner points to the necessity of checking its balance and being conscious over possible emotional identification (due to knowing participants experience as if first handedly) or the projection from the researcher onto his participants (Koppensteiner: 2018, p.74), in an effort to avoid bringing further noise into already difficult experiences. Here resides the importance of being able to welcome that which comes into the research - in this very thesis that would be the matters that International Studies deals with - war and armed conflicts, but also academic ambitions of reducing the world to a single theoretical view which is none other than an imposition of one's personal outlook on the world, based on one's own life experiences and observation tinted by their biographies. Traditionally, Peace Studies as an approach has taken part of the former, and bringing love into peace studies I hope to also deal with the latter.

\section{6 - Lederach's Three Qualities from Web-Watching:}

Last but not least, it is worth noting the parallels between the three dimensions of love I devise with the three qualities that Lederach derives from web-watching, as noted in his book The Moral Imagination (2005). Lederach considers that both conflict workers and web-watchers shared the importance of making the 
the choice of how we enter into relationship with what exists and the degree to which we keep our senses attentive to the ever-present but rarely heard appeal for authentic dialogue bubbling in our surroundings, physical and social (Lederach: 2005 p.103).

In order to engage with this authentic dialogue, Lederach considers that it is important to develop the disciplines of stillness, humility, and sensuous perception.

Stillness, for Lederach, comes from the "the presence of disciplined activity without movement. Stillness is activism with a twist. It is the platform that generates authenticity of engagement, for it is the stage that makes true listening and seeing possible. (Lederach: 2005, p.104). This true listening only takes place when we quiet the cognitive chit-chatter and processing from all discourses out there, gain focus, and open up for genuine encounter. As such, stillness may be an equivalent to what I devise as openness.

For Lederach, humility comprises two fundamental aspects: respect and connectedness. In essence, he says

Do not presume to know solutions or to provide preconceived recipes. Understand yourself as part of a larger whole. Recognize that no one person, no one process or project is capable of delivering and sustaining peace on its own. Adopt an attitude of constant learning in order to create adaptive processes capable of continuous response. (Lederach: 2005, p.107)

For me, this adaptative process capable of continuous response stands out as presence, as an ability to remaining engaged with others.

Finally, Lederach understands sensuous perception as " a capacity to use and keep open a full awareness of that which surrounds us by use of our complete faculties" (Lederach: 2005, p.108). With that, the parallel with my understanding of awareness as sensibility towards larger dimensions that are present in our most mundane acts becomes evident. 


\section{8- Final Considerations on Love and Peace Studies:}

At this point, the final considerations on love and Peace Studies arise not only from this research but also are combined with my acquired experience as a facilitator and coordinator in the Conflict Transformation and Peace Studies Program with Focus on Emotional Balance offered by Paz \& Mente in Florianópolis, in the State of Santa Catarina, Brazil. Because of its focus on Emotional Balance, a large portion of the curriculum there is based on contemplative science, which can be regarded as a secularized form of Buddhism. Familiarizing myself with contemplative science has brought me to engage with Buddhist philosophy, to consider how it approaches peace and conflict and, particularly, how it would approach my research topic of love and the way it engages with International Studies taken into Peace Studies. In line with this, in the paragraphs ahead, I discuss the compassionate basis of Buddhist philosophy as a measure to my approach to international studies within this thesis, and the relevance of such a work. In order to carry out this last task, I refer to David Loy's book titled The Great Awakening: A Buddhist Social Theory (2003). Loy is Besl Professor of Ethics/Religion and Society at Cincinnati's Xavier University and teacher in the Sanbo Kyodan tradition of Japanese Buddhism (Wisdom Publications: 2019).

According to Loy, Buddhism focuses on the alleviation of human suffering, known as dukkha. For Buddhists, dukkha is, among other things, caused by the realization of our fundamental emptiness and of the impermanence of existence, the realization that my own self, society, and all living things, even ideas, die out - similar to postmodern philosophy insights. Buddhism also considers that all of our own assumptions about our own self, about society, and about what composes all living things and the universe are no more than constructs, which function as coping, denial mechanisms to the lack of sense humans are able to give to something much greater and beyond themselves. We form these constructs 
to give meaning to our lives and as ways to deal with the suffering that comes from emptiness and impermanence (Loy: 2003 p.82). As constructs, any considerations about human life, about society, are nothing more than theories, which we learn about, assimilate, and try to use as paths to end our suffering. Of course, theories can become as polished, adapted, revisioned and grand as they can, but we will nonetheless be required to let them go, because eventually we will realize what they lack, what they do not explain, and what their limitations are. Insisting on asserting them as total truths requires an incredible amount of effort that only furthers pain.

Despite this realization of the emptiness, meaninglessness, of all existence, however, it is also important to realize that there is nothing to be filled, and seeing things for what they really are: not lacking anything at all, and what a gift it is to experience things genuinely as they are. Realizing emptiness and meaninglessness and getting to accept it may provoke a state of humbleness, but it can also often bring us to a state of nihilism. Either way, this realization brings us to a level of vulnerability and sensibility that makes ourselves so raw and exposed to contact with others that we gain a sharp perception to pain and thus act with compassion for we feel first handedly the intensity of everything. From this state, we may finally relate to others with openness, awareness and presence as ways to offer our very best. Apparently, relating in this key would seem to be a matter of choice. But, can we really look at it as mere choice? If I am concerned with the alleviation of all human suffering, and I realize the human togetherness in suffering (my own included), knowing first handed the pain and suffering deriving from the realization of emptiness and the inadequacy of any coping mechanism no matter how elaborate, than my care and compassion naturally arise as the way I engage with others.

Care and compassion, accompanied by the aspect of respect, compose thus a Buddhist way to relate to all individuals and all things, which are none other than 
overarching interpretations and constructs created and shared by others and ourselves, theoretical assumptions onto which we all cling. In this sense, even care and compassion are themselves assumptions that I, in particular and as of now, hold precious. However, in a Buddhist perspective, if we are to end our suffering, we are bound to let all theoretical assumptions go, confront their eventual inadequacy, but still treat them with the deference they deserve as meaningful efforts to come to terms with the world, as meaningful expressions of this world.

This work has not been oriented by a Buddhist perspective and one needs not to be a Buddhist in order to adopt this attitude. However, it shares such insight from Buddhism, which has provided me the most compelling argument with regards to the importance of love for peace studies: the importance of engaging with individuals with care and compassion and giving their ideas utmost respect for their focus on the alleviation of human suffering, using our best critical skills as demonstration of the value these ideas have as expressions of their proponents, especially when we are vulnerable enough and exposed to these ideas and their consequences as if they were our own. Agreement with them is not necessarily a necessity, though. In this vein, it is surprising that (except for Adam Curle) love has not been tapped into peace studies enough, but it is unsurprising that most peace scholars have laterally discussed love in one way or another, as shown in chapter two.

What was lacking, in my own perspective, was connecting love to the three main disciplines that peace studies mostly derives from, making a thorough examination of all their strains and approaches. In hindsight, that has led me to particularly disavow the more aggressive theories on International studies and address people involved, disavow the entire idea of development in favor of a more eco-conscious perspective, and disavow an imperialist/imposing particular understanding of what it means to be a human being and hold "human rights". 
What I have realized is not so much the importance of any particular strain and approach but, mostly, the importance of a certain attitude towards all of them: acting with openness, with acute awareness and being fully present to respond to them. This attitude reinforces my capability of engaging with others in a meaningful, hopefully awakened way, making my best out of it and offering others the best they deserve. Ultimately, and in practice, the chosen task carried out in this thesis finally made sense to me: first, by approaching the discourses and proponents of International Studies one after the other in a critical way. That meant that I engaged with their ideas, their contextual relevance, their limitations but let go of them, as none of them provides any stable truth or a sound way to peace and peaceful living. Second, I was quite clear on the reason that drove me to approach them from the perspective of love: because we are together in this world, in this life, it feels my duty to meet, hear, and understand them if I am to make this life experience a less difficult one for myself and others, no matter how challenging that might be, and no matter how critical it requires me to be regarding the outcomes of certain thoughts and discourses.

This is precisely the same attitude that Loy takes in his book, as he made reflections - or essays - on social theories regarding poverty, capitalism, war and so on. The simple difference between Loy's work and mine is that I focused instead on international studies and peace studies theories and discourses. In this way and, in the end, what has always mattered the most throughout the process, were the encounters I experienced with fellow scholars while engaging with their work, their ideas and how they unfolded my own critical skills about whether they were conducive to alleviate human suffering or not or whether they were not themselves expressions of suffering. Concerning this point, to use the words of Marshall Rosenberg, the intent was to see whether they are not "tragic expressions of unmet needs," an assessment that has to be open for scrutiny in order to check if this statement is a moral judgement or a mere observation. 
I believe this is a good place to stay for the time being, as debate is the spirit of academia that peace studies is a part of. However, the following are extremely important for peace studies: honing critical skills that meet the intention of being at service to alleviating the suffering of humanity and of this world, and inviting future peace workers to make this task theirs. Since this has been the central concern of the peace studies program which I collaborated with in Florianópolis, I am eager to develop future research that assesses its impact. For now, however, an understanding of love, its place in peace studies, and how it regards international studies, provides a sufficient scope for a thesis. 


\section{Conclusions to Part III- a Peace Scholarship that Includes One's}

\section{Heart:}

Regardless of the suitability and explanatory potential of all International Relations theories, going through IR theory I have finally come to terms with an overlooked, understressed but still necessary soft skill in order to reach out to these theories. This skill involves remaining open to the individuals who cross paths with me. Likewise, through the sustainability, and eco-centric critique of Development, I have grasped the importance of unfolding my own awareness to the outcomes and reverberations of my own actions in this world, and the interconnectedness of all beings and things: that qualitatively changes my own engagement with everything, giving almost a sacred aspect to it. Finally, engaging with the Ubuntu critique of Human Rights, I have apprehended what presence means: the effort of actively being of service and responding to fellow humans fellows and their needs, even in the face of hardship and when I feel like running away into abstraction and thus distancing myself.

Devising openness, awareness, and presence has allowed me to make meaning of the inherent worth of each and every living being in all our diversity, while seeking the rightful action when it comes to alleviate any form of suffering - which also means sifting the relevant insights from the pool of knowledge we have access to and discarding what is is not helpful - for each particular matter. Seeing intrinsic worth in the topics I engage with and in my process of dwelling with them (by respecting their value thus putting my critical perception to its best) are, after all, fundamental and much needed attitudes for a peace scholar. In the words of Sakyong Mipham, this is the social ramification of inherent worth. To embody this while undertaking the challenge of discussing and engaging with human 
hardships, the simple yet arduous practice of befriending, guided by unconditional acceptance, empathy, congruence, and an ethics of care, helps dissolving tensions and promotes empathy. It transforms conflicts. Last but not least, for this scholarly practice to remain meaningful, through the provision of an understanding of life as close as possible to human experience, then it must touch on all aspects of our experience, and focus on the collective process of liberation from suffering - of peace.

Practice to alleviate human suffering:

Remain open.

Unfold your awareness.

Be present and to respond to what is brought to you.

See inherent worthiness in it all.

Learn rightful action.

Befriend the world,

Care for it.

Lose abstraction, honor human experience. 


\section{General Conclusions}

We must be motivated by love in order to undertake change-love of self, love of people, love of life. Loving gives us the energy and compassion to act in the face of hardship; loving gives us the motivation to dream the life and work we want. (Gloria Anzaldúa, This Bridge Called My Back (foreword)

I started this thesis questioning if it was possible to talk about love within the social sciences. This concern stemmed from my own biographical dissatisfaction with how the larger area of International Studies discarded love as a human feature that influences the way one engages with the topic they work with, possibly as a reflex of how society regards love as form of relating to people who are not family members or sex partners. I situate myself within a Peace Studies Philosophy's Doctor $(\mathrm{PhD})$ Program, and within the research line of Philosophy for Peace, thus subsuming the epistemological turn proposed by Martínez Guzman who retrieves the inter-subjective aspect of human relations and proposes the inclusion of matters such as affection and tenderness, which are relevant human features in order to make peaces. In so doing, my effort was to investigate how peace studies could integrate love as one of its core features, and how it could transform the way it dealt with and discussed the entire heirloom of International Studies, making it distinctive in quality compared to International Relations, Development or International Human Rights. Simply, my intent was to make explicit how putting one's heart (one's capability to love) into their endeavors provides a qualitative and relational leap in the topics of International Studies and in the very scholar dealing with those topics. Therefore, the research question I formulated in order to guide this work was "how does love transform 
the discourses of International Studies in three of its disciplines - Development, Human Rights and International Relations - taken into Peace Studies? Can I find a resonance with critiques of/within these disciplines? Or can I find resonance with 'alternatives' to them? Which panorama unfolds for peace scholarship after these transformations?"

The methodology I chose in order to answer this question was a combination of discourse analysis (in order to go through International Relations, Development and Human Rights) with a trans-rational component, which understands the authors of those disciplines and my very self as sources and resources for knowing. This means our own life experience, our own feelings and intentions (my own feelings and intentions and the interpretation of feelings and intentions I derive from both an author's biography and oeuvre) are included and analyzed in the research process. Thus this comprises the human faculties otherwise ignored within the confines of the traditional social sciences, such as empathy, kindness, compassion, joy and equanimity - all of them aspects of love. I am carried by the conviction that, in this manner, research becomes a meaningful way of relating to others, drawing people closer and thus creating concrete opportunities to make peace.

However, because love still remains a contested matter for academia and is also deeply misunderstood due to popular culture, I had to start this thesis with a working definition of love, differentiating it from cathexis (a form of infatuation). Then I proceeded to a certain archaeology of the term within the West through its Greek tripartite understanding (Agape, Eros and Philia). Afterwards, I discussed the prevailing (and unbalanced) Christian interpretation of Saint Augustine focusing on Eros to the dismay of Saint Francis of Assisi's balanced Agape/Eros proposal. Subsequentelly, I examined the unfortunate legacy of Romanticism (which opposed love from the use of reason and rationality) regardless of relevant insights from Eastern perspectives such as Hinduism's 
yoga philosophy (which sees the heart chakra anahata as both heart and mind) and Buddhism's four qualities of the heart weaving how we think of and engage with the world.

From this point onwards I provide a more complex rendering of love through contemporary literature. This will include interpretations from humanistic psychology, especially through Carl Rogers' form of relating to his clients, but also through Maslow as the trailblazer of the human potentiality in their higher aspects, including the communicative aspects of love with Marshall Rosenberg, and seeing love as a form of artof-relating via Erich Fromm, requiring one to cultivate the habit of practicing it.

I also consider a rendering of love through the philosophy of Immanuel Levinas, Martin Buber and Gianni Vattimo. While Buber is considered the philosophical counterpart to Carl Rogers, seeing love as the realization of the sacred nature of (human) encounter, Levinas realizes this sacredness in the faces of the others, seeing an expression (of the) divine in them. Vattimo's philosophy, in turn, considers the predisposition necessary for such a realization to take place: with the attitude and predisposition of listening to, learning from others, one's capacity to be humble with regards to what may come.

In order to provide my understanding of love, I visit literature on politics through the thought of Paulo Freire, bell hooks and Gloria Anzaldúa. My effort with these authors was to convey the ensuing (political) action in the face of human suffering, especially with minorities experiencing systematic oppression. As hooks denounces the situation of black women, Freire denounces the situation of poverty that uneducated and illiterate people underwent, and Anzaldúa discusses invisibilized mestizos as people struggling for belonging. What is particular in this selection of authors is the way they relate to the minorities they speak about. Beyond the denunciation of their situation and the abuses they suffered, there is a passionate engagement in order to ease their suffering, devoting their lives to be in dialogue with them and being of service to the transformation of their realities. 
Last but not least in terms of a working definition of love, parallel to these perspectives, I highlight Thich Nhat Hanh's Buddhist rendering of love as the practice of the four noble qualities of the heart for others: loving-kindness, compassion, joy and equanimity, which I subscribe to and see present to a great extent in contemporary authors.

Departing from my own working definition of love, I carry on to discuss how peace scholar's have conceptualized and incorporated love in their works:

- Kenneth Boulding's focused of rightful intentionality in influencing the economic system;

- Elise Boulding's compassionately focused on silenced contributions to peace from a woman's perspective and alternative readings of mainstream history, which focuses mostly on violence;

Adam Curle was committed to alleviating the suffering of people experiencing conflict by engaging with them in the transformation of "the black cloud";

Paco Muñoz's provided a rendition and retelling of world history as marked by peace and the positive human qualities of altruism, solidarity, cooperation, kindness, tenderness, friendliness, hospitality;

Vicent Martínez Guzmán’s placed effort into rebuild/reinterpret the philosophical foundations of peace in the West, espousing them with empirical experiences of peace, and thus remaining open to and engaging with alternative and co-existing perspectives;

Lederach's work in conflict transformation highlighted people's own capability and potential, his effort on eliciting otherwise ignored common elements for the regeneration of social ties and social fabric;

Wolfgang Dietrich tapped into the understanding of anahata for conflict mapping, which stands for the use of cognitive faculties geared by unconditional love and compassion; 
And, finally, Pierre Weil focused on understanding of love as a broadening of consciousness that drives one for self-actualization - which takes place through one's work and commitment not only with oneself but especially with others, overcoming Cartesian notions of individuality.

After providing a working definition of love and how love was conceptualized in the first part of this thesis, I proceed to a second part in which I critique the main theoretical strains and perspectives within International Relations, Development and Human Rights, guided by the inference that in each and every theoretical strain and perspective that aims at providing a representation/interpretation of the world, there always is an assumption of what it means to be a human-being, their willingness to engage with their own hearts and to cast a tender and yet firm gaze over their views of the world. Thus, I highlight the human side of international studies and list the following aspects to address within each of their theories:

- Within Idealism, the desire of forging a perfect society and devising mechanisms of conflict management are directly associated with the rejection (and denial) of human proneness to violence, while within Realism, it is the very acceptance of our own darkness that leads to a resignation to see nothing but it. Behaviorism, following idealism's core aspect of understanding and managing human nature, empirically tries to determine noteworthy and consistent behaviors in an automatism that is overtly quantitative, ahistorical and unphilosophical, which leads to disconnection from concrete human life. Meanwhile, the English School focuses on the role of the law and of norms to balance realism and idealism, which stems from a pragmatic and utilitarian navigation of politics, and of people in the pursuit of self-interest. 
- The Political Economy take in IR represents the influence of abstract economic assumptions in politics, which gave way to ideology governing (overlooking) human relations, with Marxism fighting abuse over the proletariat, and Neoliberalism fueling inequality. Neo-Realism, taking from the growing role of economics in world matters, advocates the use of economic as the source for military forces to gain power and influence. It is the interpretation of Neorealism's approach as immoral that composes the main tenets of a Critical School of IR, influenced by the Marxist understandings within the philosophy of the Frankfurt School.

- Within the influence of philosophy, it is through the echoes of postmodernism that Post-Positivist theories within IR pay attention to humans left out of power debates and the grand narrative of modern State-Centric accounts. In the meantime, Constructivism appears as a novel theoretical strand within IR Constructivism, focusing on the willpower to intervene and reshape order and yield "new" social facts that influence the international debate. In a similar way, both feminism and Post-Colonialism focus on highlighting and addressing the historical blindness towards the violence suffered and experienced by those left out of power-politics: women, the queer, and the colonized.

When it comes to Development, I highlight the deep-seated fear that resides within Economics, as the discipline from which Development derives from, that leads to the accumulation of wealth as a form of protection against misery and ends up as greed. That is particularly the case for the liberal tradition of Smith and Ricardo. However, Keynesian tradition did not necessarily go much further with a certain thirst for control over the flows of capital in order to curb anxiety for economic derailments, which eventually leads to the establishments of an international economic agenda and praxis via the creation of 
international financial institutions such as the World Bank, IMF and the General Agreement on Trades and Tariffs (GATT). Under this apparently beneficial modernization flag, and espousing Growth Theory, Development was coined as a concept for wellbeing within the Truman Doctrine, which served especially as deterrence to the USSR and its influence of Communism. However, within the Capitalist block there was dissent enough to trigger a neoliberal, greedy reaction enshrining rugged individualism/egoism during the economic crisis of the seventies and the implementation of the Washington Consensus which proved damaging to people's wellbeing and actually created more poverty, vulnerability, inequality and a tying dependency, as argued by Dependencia theorists. The Truman Doctrine on development was never challenged as a concept and made its way into the fundament of every national policy. It led to the creation of interventionist initiatives such as social development, rural development, sustainable development and human development. These initiatives may all intend to better human life but end up uniformizing them into acceptable standards. These uniformizations culminated in Global Initiatives such as the well-intended Millennium Development Goals (MDGs), which of course demonstrate concern, but in a paternalist and thus problematic way.

As a faculty that promotes engagement with fellow human beings instead of focusing on determining people's needs, how they are to conduct their life, and what to change, loving requires us to meet and celebrate people within their own grounds. In practice, this would mean learning from and working with giving value to local, contextual, culturally bound, multiple forms of socialization and relating, unless these are hindering people's own unfolding. This was the attitude that led the critical perspectives of development to halt and denounce the malaise generated by development defenders, following Ivan Illich, the poignant voices of Wolfgang Sachs and Arturo Escobar, and the search for alternatives of Gustavo Esteva. These alternatives became fundamental for a 
context in which the impacts of leading a modernized, developed lifestyle are promoting a point of no regeneration for several ecosystems, as demonstrated in The Limits to Growth (2004) and observed through global warming. Thus, I presented the perspectives of buenvivir, deep ecology, and the ecofeminist approach to sustainable peasantry, for being in tune with love's attitude of seeing intrinsic worth in localized, contextual, culturally bound, multiple forms of socialization and relating, especially those which aim at environmental and social regeneration, going beyond sustainability, in comparison to a modernized, developed lifestyle.

In terms of the International Human Rights discourse, at first sight, sustaining a perspective that safeguards human life may seem absolutely coherent with a compassionate attitude, concerned with others and their lives. There is little doubt that the Human Rights discourse emerged within the framework of the United Nations (within the then-called Human Rights Commission), in its exercise of politics guided by compassion and respect for human life, by developing prevention plans against human suffering, especially the widespread violence of World War II. As demonstrated by the study requested to and carried out by the UNESCO, it was also conceived with a great deal of concern over cultural differences. In such a multilateral forum as the UN, it turns out that the debate about the ideological nature of certain groupings of human rights and the binding powers that the ensuing Human Rights covenants have, could very much affect the international balance of power. Thus, human rights as a discourse turned into a political tool amid the Cold War.

At the same time, because of the growing appeal of the Human Rights discourse and the widespread claims of human rights (ab)use, several critiques were made to it: its assumptions of universality and prevalence as a sole way of relating; its essentialist emphasis on a substantive individual in detriment to conceptions of self that cannot be dissociated from groupings; its anthropocentrism; its legalism and enforcement through 
coercion; its gendered standards; and its favoring of normative abstraction in the face of others (its ubuntu critique). Eventually, the importance of tuning to one's heart as a drive to relate to others and reduce human suffering both nurtures the mechanisms available to prevent violence and safeguards Human Rights. However, first and foremost, this heart centering reasserts one's capability and challenge to respond to suffering in its own context, demanding genuine openness for understanding local forms of relating and addressing conflict and strengthening them. Therefore, it is important to understand that the observation and respect of human rights is a continuous praxis. It is a process that demands full commitment.

Ultimately, within one particular critique of IR, one of Development, and one of Human Rights, I have realized three complementary skills that are of great importance when casting a loving gaze into the matters of the world discussed within International Studies and which I have brought into Peace Studies: openness, awareness, and presence with the aid of theme-centered interaction as a process-oriented tool to balance attention to relevant elements in a peace scholarship. Openness brings about the condition to engage with others; awareness gives a greater sense of purpose for doing so, and presence reasserts commitment. Ultimately, these become forms of practicing and realizing (as Trungpa would assert) basic human goodness, while operating a shift from International Studies towards an almost phenomenological and humanistic approach to Peace Studies, giving "a greater purpose to the art of thinking" (as Lewis Gordon would put). The practice of peace scholarship emerging out of this is necessarily one that brings people closer together, giving meaning to Curle's befriending. It is marked by Comins' and Gilligan's care ethics and Rogers' congruence, empathy and acceptance. Honoring our human potential, Koppensteiner proposes elicitive facilitation, providing our very best to alleviate human suffering. 
As such, integrating love in peace studies gives form to a scholarship that emphasizes relational aspects in educational contexts in both teaching and researching, while not eschewing from critically addressing the intellectual production generated thus far in international studies from which peace studies departs. Love in peace studies is a form of making the discipline contextually relevant to participants, providing a glimpse of the potential of a caring and nurturing social environment. Finally, love in peace studies is for me, creating exactly this caring and nurturing social environment which I came to experience in my life and hope to transform. 


\section{Conclusiones generales (en Castellano):}

He empezado esta tesis mencionando la imposibilidad de hablar sobre el amor dentro de las ciencias sociales. Me hice consciente de esta limitación en mi propia experiencia biográfica, al ver como la forma en que el área específica de los Estudios Internacionales había descartado considerar el amor como una característica humana que influye en la forma en que uno se involucra con el tema con el que trabaja. Esta limitación, posiblemente, no es más que un reflejo de una sociedad que considera el amor como una forma de relacionarse exclusiva para familias o parejas. Sin embargo, me sitúo dentro de un Programa de Doctorado en Estudios de Paz, dentro de la línea de investigación de Filosofía para la Paz y, por lo tanto, me subsumo al giro epistemológico propuesto por Martínez Guzmán, que recupera el aspecto intersubjetivo de las relaciones humanas y que propone la recuperación de aspectos como el cariño y la ternura, como rasgos humanos fundamentales para hacer las paces. Así, mi esfuerzo ha sido el de investigar cómo los estudios de paz podrían integrar una idea más amplia del amor - que incluye el cariño y la ternura - como una de sus características centrales, y cómo esta integración transforma la el contenido y forma con que tratamos y discutimos el conocimiento heredado de los estudios internacionales por los Estudios de Paz. Así, ofrezco un enfoque cualitativamente distinto a relaciones internacionales, el desarrollo y a los derechos humanos Internacionales. En términos simples, mi intención era hacer explícito cómo el hecho de poner el corazón de uno mismo (la capacidad de amar) en sus esfuerzos proporciona un cambio cualitativo y relacional del investigador con los temas de Estudios Internacionales y con los individuos detrás de los estudios internacionales, revelando un mundo más humano. Por tanto, la pregunta de investigación que formulé para orientar este trabajo fue 
“CCómo transforma el amor los discursos de los Estudios Internacionales en tres de sus disciplinas (Desarrollo, Derechos Humanos y Relaciones Internacionales) tomadas en Estudios de Paz? ¿Puedo encontrar resonancia con las críticas hechas a estas disciplinas? ¿Encuentro resonancia con "alternativas" a estas disciplinas? ¿Qué panorama se abre para la investigación por la paz después de estas transformaciones?”.

La metodología que he elegido para responder a esta pregunta fue una combinación de análisis del discurso (de las Relaciones Internacionales, Desarrollo y Derechos Humanos) con un componente transracional que comprende no sólo el contenido sino también a los individuos autores en esas disciplinas y a mí mismo como fuentes y recursos del conocimiento. Es decir, incluyo y analizo en mi investigación nuestra propia experiencia de vida, nuestros propios sentimientos e intenciones (mis propios sentimientos e intenciones y la interpretación de sentimientos e intenciones que derivo tanto de la biografía como de la obra de un autor). De esta forma puedo ejercitar así los aspectos del amor tradicionalmente ignorados dentro de las ciencias sociales, como la empatía, la bondad, la compasión, la alegría y la ecuanimidad, todos ellos aspectos del amor. Llego a la conclusión de que, de esta manera, la investigación se convierte en una forma significativa de relacionarse con los demás, acercando a las personas y creando así oportunidades concretas para hacer las paces.

Sin embargo, debido a que el amor sigue siendo un tema controvertido para la academia y también sigue siendo profundamente incomprendido en la cultura popular, al principio de esta tesis he ofrecido una definición práctica del amor, diferenciándolo de la catexis (una forma de enamoramiento) para luego proceder a una cierta arqueología del término en el Occidente, a través de su comprensión tripartita griega (Agape, Eros y Philia); la interpretación cristiana predominante (y desequilibrada) de San Agustín centrada en Eros en detrimento del equilibrio entre Ágape y Eros propuesto por San Francisco de Asís; y, 
finalmente, el desafortunado legado del romanticismo, que opuso el amor al uso de la razón y la racionalidad - a pesar de todas relevantes contribuciones sobre el tema desde las perspectivas orientales, como por ejemplo la filosofía del yoga del Hinduismo (que ve el chakra del corazón (anahata) como integración del corazón y de la mente y las cualidades del corazón en el Budismo, que dictan prácticas sobre cómo pensar y relacionarse con el mundo de manera pacífica y no violenta.

Desde este punto en adelante he proporcionado una interpretación más compleja del amor a través de la literatura contemporánea especializada. Esto ha incluido interpretaciones a partir de la psicología humanista, especialmente a través de la forma de Carl Rogers de relacionarse con sus clientes y también a través de Abraham Maslow como el pionero de la potencialidad humana en sus formas más elevadas. He incluido también los aspectos comunicativos del amor con Marshall Rosenberg, y he considerado el amor como un arte de relacionarse a través de Erich Fromm, que requiere que uno cultive y practique el amor como diligente hábito.

También he considerado una representación del amor en la filosofía, a través de los escritos de Emmanuel Levinas, Martin Buber y Gianni Vattimo. Mientras que Buber es considerado la contraparte filosófica de Carl Rogers por ver el amor como la manifestación del sagrado en el encuentro (humano), Levinas se da cuenta de que el sagrado se realiza en los rostros de los demás, viendo una expresión (de) divino en ellos. La filosofía de Vattimo, a su vez, considerará la predisposición necesaria para que se produzca tal realización del sagrado bien en el encuentro o en la observación del otro, a través de la actitud de apertura y predisposición de escuchar, aprender de los demás, la capacidad de ser humilde ante lo que surge.

Otra área de la literatura académica que analiso para ofrecer una comprensión ampliada del amor es a través de la política, a través del pensamiento de Paulo Freire, bell 
hooks y Gloria Anzaldúa. Mi intención con estas autoras ha sido el de evidenciar acciones (política) necesarias ante el sufrimiento humano, especialmente con colectivos que experimentan opresión, como hooks denuncia la situación de las mujeres negras, Freire denuncia la situación de pobreza que viven las personas analfabetas o sin educación, y Anzaldúa analiza a los mestizos invisibilizados como personas que luchan por pertenencia y que detienen potencial de integración. Lo particular de esta selección de autores es su forma de relacionarse con los colectivos de los que hablan: más allá de la denuncia de su situación y los abusos que sufren, en estos autores hay un compromiso apasionado para aliviar su sufrimiento, habiendo dedicado sus vidas a estar en diálogo con ellos y al servicio de la transformación de sus realidades.

Por último, pero no menos importante en términos de una análisis y definición general y práctica del amor, paralela a las perspectivas mencionadas arriba, destaco la interpretación practico-espiritual-filosófica budista del amor de Thich Nhat Hanh como la práctica de las cuatro cualidades nobles del corazón para los demás: bondad amorosa, compasión, alegría y ecuanimidad, que suscribo y veo presente en gran medida en los autores contemporáneos.

Siguiendo mi propia definición del amor a través de los autores y autoras mencionados, continúo la tesis evidenciando cómo los estudiosos de la paz han puntualmente conceptualizado e incorporado el amor en sus trabajos: el aspecto de la intencionalidad legítima para influir en el sistema económico de Kenneth Boulding; El enfoque compasivo de Elise Boulding en las contribuciones silenciadas a la paz desde la perspectiva de las mujeres y las lecturas alternativas de la historia tradicional, que se centra principalmente en la violencia; El compromiso de Adam Curle de aliviar el sufrimiento de las personas que experimentan conflictos violentos al participar con ellos en la transformación de "la nube negra"; La interpretación y el recuento de Paco Muñoz de la 
historia mundial marcada por la paz y las cualidades humanas positivas del altruismo, la solidaridad, la cooperación, la bondad, la ternura, la simpatía, la hospitalidad; El esfuerzo de Vicent Martínez Guzmán por reconstruir / reinterpretar los fundamentos filosóficos de la paz en Occidente, apoyándolos en experiencias empíricas de paz y, por tanto, permaneciendo abiertos y comprometidos con perspectivas alternativas y coexistentes; El trabajo de Lederach en la transformación de conflictos al destacar la propia capacidad y el potencial de las personas y su esfuerzo por buscar elementos por veces ignorados y sin embargo relevantes para la regeneración de los lazos personales y el tejido social; La comprensión de Wolfgang Dietrich del anahata para el mapeo de conflictos, que representa el uso de facultades cognitivas orientadas por el amor incondicional y la compasión; y, finalmente, la comprensión de Pierre Weil del amor como una ampliación de la conciencia que impulsa a uno mismo a la autorrealización, que tiene lugar a través del trabajo y el compromiso especialmente con los demás, superando las nociones cartesianas de individualidad.

Después de proporcionar el análisis y génesis del amor y explicitar cómo este se ha conceptualizado en los estudios de paz en la primera parte de esta tesis, procedo a una segunda parte en la que critico las principales ramas y perspectivas teóricas de las Relaciones Internacionales, del discurso del Desarrollo, y de los Derechos Humanos Internacionales. En este proceso de crítica, me guio por el hecho de que en todas y cada una de las ramas y perspectivas teóricas de estas disciplinas y sus respectivos autores hay siempre una suposición de lo que significa ser humano y se puede derivar de sus escritos y biografía sus fuerzas y voluntad de comprometerse con sus propios corazones. De esta forma puedo emitir una mirada enternecedora aunque firme sobre sus interpretaciones de mundo, derivando así conocimiento crítico combinado con el establecimiento de un vínculo y relación con los autores de los Estudios Internacionales a través de sus ideas, aunque estas 
ideas no sean suficientes como para cambiar las relaciones humanas tal y como se considera necesario en los estudios de paz. De este modo, ejercito el aspecto humano de los estudios internacionales y evidencio una manera de establecer el tipo de relación no-violenta que se fomenta en los estudios de paz.

En las vertientes teóricas de Relaciones Internacionales, estos son los aspectos centrales que he destacado en cada de ellas:

- Dentro del idealismo, el deseo de forjar una sociedad perfecta e idear mecanismos de manejo de conflictos están directamente asociados con el rechazo (y negación) de la capacidad humana de hacer uso de la violencia, mientras que dentro del realismo, está la aceptación de nuestra propia oscuridad lo que conduce a una resignación que no ve nada más que eso. El behaviorismo, siguiendo el aspecto central del idealismo de idear mecanismos para gestionar la naturaleza humana, se centra en empíricamente determinar comportamientos arraigados y consistentes asumiendo un automatismo innegablemente cuantitativo, ahistórico y nofilosófico, que conduce a una desconexión con la vida humana concreta. Mientras tanto, la Escuela Inglesa se centra en el papel de la ley y de las normas para equilibrar el realismo y el idealismo, que surge de un uso pragmático y utilitario de la política y de las personas en la búsqueda del interés propio que puede degenerar en egocentrismo.

- La perspectiva de la Economía Política en las RI representa la influencia de supuestos económicos abstractos en la política, que dieron paso a que una ideología gobiernara (ignorara) las relaciones humanas, con el marxismo luchando contra el abuso de la clase trabajadora y el neoliberalismo alimentando la desigualdad. Con ello, el neorrealismo, tomando el creciente 
papel de la economía en los asuntos mundiales, aboga por el uso de la economía como fuente de poder combinado con las fuerzas militares para la obtención de influencia y protagonismo. Ya la Escuela Crítica de las Relaciones Internacionales considera el enfoque del neorrealismo como inmoral, siendo influenciada por la filosofía marxistas de la Escuela de Frankfurt.

- Dentro de la influencia de la filosofía en las RRII, es a través de los ecos del posmodernismo que las teorías post-positivistas dentro de las RI prestarán atención a aquellos excluidos de los debates sobre el poder y la gran narrativa de los relatos modernos centrados en el Estado. Mientras tanto, el constructivismo aparece como una nueva corriente teórica dentro del de las RRII, centrándose en la fuerza de voluntad para intervenir y remodelar el orden y producir "nuevos" hechos sociales que influyen en el debate internacional. De manera similar, tanto el feminismo como el poscolonialismo se enfocan en resaltar y abordar la ceguera histórica hacia la violencia sufrida y la experiencia de los excluidos de la política de poder: las mujeres, los queer y los colonizados.

Con respecto al discurso de Desarrollo, destaco el miedo como elemento central y profundamente arraigado en la economía, en cuanto disciplina de la que deriva el Desarrollo. Es este miedo el que conduce a la percibir la necesidad de acumulación de riqueza como forma de protección contra la miseria y que paulatinamente justifica la codicia. Ese es particularmente el caso de la tradición liberal de Smith y Ricardo. Sin embargo, la respuesta keynesiana al liberalismo clásico no ha ido mucho más allá, teniendo en cuenta su ansiedad por el control sobre los flujos de capital para frenar su inseguridad sobre posibles problemas macroeconómicos, lo que eventualmente ha conducido al 
establecimiento de una agenda y praxis económica internacional a través de la creación de instituciones financieras internacionales como el Banco Mundial, el FMI y el Acuerdo General sobre Comercio y Aranceles (GATT).

Bajo esta bandera de modernización aparentemente beneficiosa, y defendido por la Teoría del Crecimiento, el Desarrollo fue acuñado en la Doctrina Truman como un concepto clave para el bienestar, que ha servido especialmente como disuasión de la URSS y su influencia con el Comunismo. Independientemente de esta polarización de ideas, con la crisis económica de los años 70 y los procesos de descolonización, no hubo dentro del bloque capitalista suficiente cohesión como para evitar una respuesta neoliberal por parte de los países capitalistas dominantes - sobretodo EE. UU. e Reino Unido, lo que acabó por estimular y, finalmente, consagrar el individualismo y el egoísmo a nivel nacional e individual. A partir de la fuerza de esta respuesta neoliberal, a nivel internacional se ha procedido a la implementación del Consenso de Washington como régimen económico, que luego se ha podido comprobar perjudicial para el bienestar de las personas y que de hecho ha generado aún más pobreza, vulnerabilidad, desigualdad y, según los teóricos de la dependencia, una dependencia vinculante.

Aún así, desde su aparecimiento en la Doctrina Truman hasta finales del siglo XX, el concepto de desarrollo no había sido suficientemente cuestionado, permitiendo que estuviera presente en todas las políticas nacionales e iniciativas intervencionistas como el desarrollo social, desarrollo rural, desarrollo sostenible y desarrollo humano. Todas ellas formas de abordar la vida humana que terminan por uniformizarlas en estándares basados en la vida del Norte Global ajenas a la diversidad humana, culminando en Iniciativas Globales como los bien intencionados Objetivos de Desarrollo del Milenio (ODM) que, por supuesto demuestran preocupación con la calidad de vida humana, pero de una manera paternalista y por lo tanto problemática. 
Como una facultad que promueve el compromiso y la relación con los demás seres humanos y la transformación de sus dificultades, en lugar de centrarse en determinar las necesidades de las personas, cómo deben conducir su vida y qué deben cambiar, el acto de amor requiere que conozcamos y celebremos a las personas en sus propios contextos y perspectivas y estemos abiertos a apoyarles y trabajar juntos en sus desafíos. En la práctica, esto significaría aprender y trabajar para reconocer las múltiples formas de vivir, organizarse y relacionarse existentes en el mundo, sus contextos y la cultura a que pertenecen, involucrándose en ellas y en los conflictos que surjan. Esta ha sido la actitud que llevó a los críticos del desarrollo a frenar y denunciar el malestar y daño generado por el proyecto del desarrollo. La crítica al desarrollo se ha basado mayoritariamente en los escritos de Ivan Illich, las elocuentes voces de Wolfgang Sachs y Arturo Escobar, y en la búsqueda por alternativas de Gustavo Esteva. En un momento en el cual los impactos medioambientales generados por un estilo de vida "desarrollado y modernizado" nos están conduciendo un punto de no-regeneración para varios ecosistemas, como se ha demostrado en The Limits to Growth (2004) y se observa a través del cambio climático y calentamiento global, las perspectivas del buen vivir, la ecología profunda, y el enfoque ecofeminista del campesinado de subsistencia, evidencian una gran sintonía con la actitud del amor de empatía, compasión, bondad y ecuanimidad, al ver el valor intrínseco en formas múltiples de socialización y relación localizadas, contextuales, culturalmente vinculadas en harmonía con el medioambiente y otras formas de vida no-humanas, especialmente aquellas que apuntan a la regeneración ambiental y social, yendo más allá de la sostenibilidad, en comparación a un estilo de vida desarrollado y modernizado.

En términos del discurso internacional de derechos humanos, a primera vista, sostener una perspectiva que salvaguarda la dignidad y la vida humana puede parecer absolutamente coherente con una actitud compasiva y comprometida por los demás y sus 
vidas. Al final, demuestro que el discurso de los Derechos Humanos surgió en el marco de las Naciones Unidas (dentro de la entonces llamada Comisión de Derechos Humanos), con el objetivo de crear y hacer una política guiada por el respeto a la vida y diversidad humana, desarrollando planes de prevención contra el sufrimiento humano, especialmente el sufrimiento derivado violencia generalizada vivida durante la Segunda Guerra Mundial. Este discurso internacional de los derechos humanos fue concebido con una gran preocupación por las diferencias culturales, como lo demuestra el estudio realizado por la UNESCO capitaneado por Jacques Maritain. Pero, resulta que en un foro multilateral como lo es la ONU, el debate sobre la naturaleza ideológica de ciertos grupos de derechos humanos y los poderes vinculantes que podrían tener los Pactos de Derechos Humanos subsiguientes podría afectar mucho el equilibrio internacional de poder y, por ello mismo, los derechos humanos en cuanto discurso por la dignidad humana se han convertido en herramienta política durante de la Guerra Fría.

Al mismo tiempo, debido al creciente atractivo del discurso de los derechos humanos y los reclamos generalizados de su (ab)uso, he evidenciado varias críticas con relación al mismo: sus supuestos de universalidad y prevalencia como única forma de entender la dignidad humana; su énfasis esencialista en un individuo sustantivo en detrimento de las concepciones del yo que no pueden disociarse de agrupaciones; su antropocentrismo; su legalismo y ejecución mediante punición; sus estándares de género; y su preferencia por la abstracción normativa ante la diferencia (la crítica desde el ubuntu). Finalmente, he destacado que la búsqueda por coherencia con un concepto del amor, como un impulso para relacionarnos con los demás y para reducir el sufrimiento humano, alimenta los mecanismos disponibles para prevenir la violencia y salvaguardar los derechos humanos, pero también reafirma la capacidad y el desafío de responder al sufrimiento en sus especificidades, exigiendo una genuina apertura para entender las formas culturalmente 
diversas de relacionarse y abordar los conflictos y fortalecer la dignidad humana, entendiendo así que la observación y el respeto de los derechos humanos es un proceso que exige un compromiso que requiere, por veces, despojarse incluso de los derechos humanos como única manera de concebir la dignidad humana.

Finalmente, con la ayuda de un método de abordaje de problemas centrada en el proceso conocido como "interacción centrada en el tema", he podido identificar, en una crítica particular a las Relaciones Internacionales, en una crítica particular al Desarrollo y en una crítica a los Derechos Humanos, 3 habilidades que son de gran importancia para una mirada a los asuntos mundiales discutidos dentro de los Estudios Internacionales e incorporados los Estudios de la Paz: apertura, conciencia (awareness) y presencia.

A mi ver, la apertura, que surge del reconocimiento e interés espontáneo por el otro, promueve el impulso para explorar nuestra relación con los demás; la conciencia (awareness), que surge del reconocimiento más profundo de nuestra interrelación y complejidad, invita a comprender con propiedad esta interrelación; y, finalmente, la presencia reafirma el compromiso con la interacción con el otro.

La exploración de estas habilidades reafirma (como diría Trungpa) la bondad humana básica, a la vez que permite operar un cambio del contenido de los Estudios Internacionales en los Estudios de Paz a través de un enfoque, en la práctica, fenomenológico y humanista, dando "un mayor propósito al arte de pensar" (como diría Lewis Gordon): el de convivir y relacionarse con los demás. Así, la investigación y enseñanza de los estudios de paz que surge de esto, es necesariamente una que acerca a las personas, dando sentido al befriending de Curle; está marcado por la ética del cuidado de Comins y Gilligan, por la congruencia, empatía y aceptación de Rogers; ejercita la quietud, humildad y percepción sutil como propuesta por Lederach, y honra nuestro potencial 
humano, como el que propone Koppensteiner en su facilitación "elicitiva”, explorando nuestras competencias para aliviar el sufrimiento humano.

Así, la integración del amor en los estudios de paz da forma a un conocimiento crítico que enfatiza el aspecto relacional en los contextos educativos, tanto en la docencia como en la investigación, sin dejar de abordar críticamente la limitación de la producción intelectual generada hasta el momento en los estudios internacionales de la cual que se deriva los estudios de paz. El amor en los estudios de paz son una forma de hacer con que la disciplina sea relevante para todos sus co-participantes, explorando el potencial de un entorno social genuinamente enriquecedor. Finalmente, el amor en los estudios de paz es para mí, la exacta creación del entorno social, profesional e intelectual compasivo e inspirador que me ha costado experimentar y que, de ahora adelante, me gustaría promover. 


\section{List of References}

ABRAM, D. (2011) Becoming Animal. New York: Vintage Books.

ACHARYA, A. AND BUZAN, B. (2010) Non-Western international relations theory: perspectives on and beyond Asia. London: Routledge.

ALCOFF, L. AND MENDIETA, E. (2000) Thinking from the underside of history: Enrique Dussel's Philosophy of liberation. Lanham: Rowman \& Littlefield Publishers.

ANDERSON, B.R.O. (2016) Imagined communities : reflections on the origin and spread of nationalism. London: Verso.

ANZALDÚA, G. (2007) Borderlands : the new mestiza = La frontera. 3rd ed. San Francisco: Aunt Lute Books.

ANZALDÚA, G AND MORAGA, A. (2015) This bridge called my back: writings by radical women of color. New York: Kitchen Table Press.

ASHLEY, R. K. (1988) 'Untying the Sovereign State: A Double Reading of the Anarchy Problematique', Millennium: Journal of International Studies, 17(2), pp. 227-262.

BADIOU, A. AND TRUONG, N. (2009) Eloge de l'amour. Paris: Flammarion.

BEITZ, C. (2003) 'What Human Rights Means', Daedalus, 132(1), pp. 36-46.

. (2009) The Idea of human rights. New York: Oxford University Press.

BENJAMIN, W. AND ARENDT, H. (1968) Illuminations. New York: Schoken.

BENNETT, H. (2017) 'Love', Stanford Encyclopedia of Philosophy. Stanford University. Available at: https://plato.stanford.edu/archives/fall2017/entries/love/ (Accessed: 6 February 2019).

BESSEL, R. (2017) 'Post-war Societies', 1914-1918-online. International Encyclopedia of the First World War. Freie Universität Berlin. 
BIGO, D. AND WALKeR, R. B. J. (2007) 'Political Sociology and the Problem of the International', Millennium: Journal of International Studies. Sage Publications, 35(3), pp. $725-739$.

BIZERRA, C. (2010) The Indigenous Decolonial Concept of 'Buen Vivir' in Latin America. Available at: https://www.indybay.org/newsitems/2010/02/28/18639072.php (Accessed: 5 March 2019).

BOUlDing, E. (2000) Cultures of peace: the hidden side of history. Syracuse, N.Y.: Syracuse University Press.

. (1976) The underside of history: a view of women through time. Boulder: Westview Press.

BOULDING, E. AND IKEDA, D. (2010) Into full flower: making peace cultures happen. Cambridge, Mass.: Dialogue Path Press.

BOULDING, K. E. (1963) Conflict and defense: a general theory. New York: Harper Torchbooks.

. (1976) The economy of love and fear; a preface to grants economics. 2nd edn. Belmont: Wadsworth Pub. Co. . (1978) Stable peace. Austin: University of Texas Press.

BROWN, C. AND AINLEY, K. (2005) Understanding international relations. Basingstoke: Palgrave Macmillan.

BRUNDTLAND, G. (1987) Report of the World Commission on Environment and Development: Our Common Future. New York. Available at: http://www.undocuments.net/our-common-future.pdf.

BRUSSAT, F. AND BRUSSAT, M. A. (no date) Living Spiritual Teachers Project Leonardo Boff, Spirituality \& Practice: Resources for Spiritual Journeys. Available at: https://www.spiritualityandpractice.com/explorations/teachers/view/11 (Accessed: 11 March 2019).

BUBer, M. AND KAUfmAnN, W. (1996) I and Thou. 1st Touchs. New York: Charles Scribner's Sons. 
BULL, H. (2012) The anarchical society: a study of order in world politics. 4th ed. $/$. Basingstoke: Palgrave Macmillan.

BUSH, G. (2002) The national security strategy of the United States of America. Washington: Executive Office of the President.

BUTLER, J. (2015) ‘+Humans. El futur de la nostra espècie'. Barcelona: Centre de Cultura Contemporània de Barcelona.

. (2015) 'The Ward-Phillips Lecture'. Notre Dame, Indiana.

BUZAN, T. AND BUZAN, B. (2010) The mind map book. London: BBC Books.

CARR, E. (1946) The twenty years' Crisis, 1919-1939 an introduction to the study of international relations. London: Macmillan.

CHAMBERS, R. (1984) Rural development : putting the last first. Harlow : Longman.

CLARK, D. A. (2006) The Elgar Companion to Development Studies. Edited by D. A. Clark. Northampton: Edward Elgar Publishing.

CMIEL, K. (2004) 'The Recent History of Human Rights', The American Historical Review. Oxford University Press, 109(1), pp. 117-135.

COMINS MINGOL, I. (2009) Filosofía del cuidar : una propuesta coeducativa para la paz. Barcelona : Icaria.

CONAMEDIC (2017) Nossas emoções nascem no coração ou no cérebro? Professora Doutora Elisa Harumi Kozasa. Brazil: Congresso Nacional de Medicina Integrativa e Comportamental On-line. Available at: https://youtu.be/jMbIwMQ2m5E.

CONSEJO INDÍGENA DE CENTROAMERICA (2020) Principios. Available at: http://www.consejocica.org/principios-del-buen-vivir/

COX, R. W. (1981) 'Social Forces, States and World Orders: Beyond International Relations Theory', Millennium: Journal of International Studies. Sage Publications, 10(2), pp. 126155.

CURLE, A. (2006) The fragile voice of love. Charlbury, England: Jon Carpenter Pub.

CUlLINAN, C. (2019). Nature Rights. In KOTHARI, A. ET AL. (2019) Pluriverse: a postdevelopment dictionary. Delhi, India. Tulika Books. 
DE VOGEL, C. J. (1981) 'Greek Cosmic Love and the Christian Love of God: Boethius, Dionysius the Areopagite and the Author of the Fourth Gospel', in Vigiliae Christianae. Brill, 35(1), pp. 57-81.

DEPARTMENT OF STATES OF THE UNITED STATES (1944) 'Proceedings and Documents of the United Nations Monetary and Financial Conference', in. Bretton Woods, New Hampshire. Available at: https://fraser.stlouisfed.org/title/430/item/7569 (Accessed: 25 February 2019).

DESCARTES, R. (1934) The philosophical works of Descartes. London: Cambridge University Press.

DIETRICH, W. (2011) The Palgrave international handbook of peace studies : a cultural perspective. New York: Palgrave Macmillan.

. (1997) A call for many peaces. Stadtschlaining Austria: Peace Center Burg Schlaining.

. (2018) Elicitive Conflict Mapping. London: Palgrave Macmillan UK.

. (2013) Elicitive Conflict Transformation and the Transrational Shift in Peace Politics. London: Palgrave Macmillan UK.

DIETRICH, W. AND KOPPENSTEINER, N. (2012) Interpretations of peace in history and culture. Houndsmills: Palgrave Macmillan.

DOMÍNGUEZ MARTÍN, R. AND CARIA, S. (2014) 'La ideología del Buen Vivir: la metamorfosis de una alternativa al desarrollo en desarrollo de toda la vida.', Pre-textos para el debate, n. 2 (2014). Universidad Andina Simón Bolívar. Available at: https://repositorio.unican.es/xmlui/handle/10902/9829 (Accessed: 17 October 2019).

DOS SAntos, T. (1970) 'The Structure of Dependence', The American Economic Review. American Economic Association, 60(2), pp. 231-236.

EARTH CHARTER INTERNATIONAL SECRETARIAT (2000) The Earth Charter. San José Costa Rica: Earth Charter Secretariat Earth Council.

ECHAVARRÍA ALVAREZ, J., INGRUBER, D. AND KOPPENSTEINER, N. (2018) Transrational resonances : echoes to the many peaces. Cham: Palgrave Macmillan. 
EMON, A. M., ELLIS, M. S. AND GLAHN, B. (2012) Islamic law and international human rights law. Oxford: Oxford University Press.

ENGEL, C. C., J. (2004) 'Post-War Syndromes: Illustrating the Impact of the Social Psyche on Notions of Risk, Responsibility, Reason, and Remedy', Journal of the American Academy of Psychoanalysis and Dynamic Psychiatry, Tomo 32, N, pp. 321-34, discussion $335-43$.

ENLOE, C. H. (2000) Bananas, beaches and bases : making feminist sense of international politics. Berkeley California; London: University of California Press.

ESCOBAR, A. (1995) Encountering development: the making and unmaking of the Third World. Princeton, N.J.: Princeon University Press.

. (2006) 'Post-Development', in Clark, D. A. (ed.) The Elgar Companion to Development Studies. Northampton: Edward Elgar Publishing.

. (1992) 'Imagining a Post-Development Era? Critical Thought, Development and Social Movements' in Social Text. Duke University Press, (31/32), p. 20. Available at: https://www.jstor.org/stable/466217?origin=crossref.

ESTEVA, G. (2009) 'Más allá del desarrollo: la buena vida', América Latina en Movimiento, June. Available at: https://www.alainet.org/sites/default/files/alai445w.pdf.

EUROPEAN GRADUATE SCHOOL (2015) bell hooks- Biography. Available at: http://www.egs.edu/library/bell-hooks/biography/ (Accessed: 27 October 2015).

FANON, F., SARTRE, J.-P. AND FARRINGTON, C. (1965) The wretched of the earth. New York: Grove Press.

FERBER, M. (2010) Romanticism : a very short introduction. Oxford: Oxford University Press.

FLYNN, T. (2013) 'Jean-Paul Sartre', The Stanford Encyclopedia of Philosophy. Edited by E. N. Zalta. Available at: https://plato.stanford.edu/cgibin/encyclopedia/archinfo.cgi?entry=sartre (Accessed: 6 July 2020).

FOOD AND AGRICULTURE ORGANIZATION OF THE UNITED NATIONS. (2012) FAO Statistical Yearbook 2013 - World Food and Agriculture. Rome: FAO. 
FORAStelli, F. (2013) 'Peace Profile: Vicent Martínez Guzmán', in Peace Review. Taylor \& Francis Group, 25(3), pp. 439-446. Available at: http://www.tandfonline.com/doi/abs/10.1080/10402659.2013.816573.

FREIRE, P. (2005) Pedagogy of the oppressed. 30th anniv. New York; London: Continuum. FRIEDMAN, M. S. (2002) Martin Buber : the life of dialogue. London: Routledge. FRIEDMAN, T. L. (2007) The world is flat: a brief history of the twenty-first century. New York: Picador/Farrar, Straus and Giroux.

FROMM, E. (1995) The Art of Loving. London: Thorsons.

GADE, C. B. N. (2011) 'The historical development of the written discourses on Ubuntu', South African Journal of Philosophy = Suid-Afrikaanse Tydskrif vir Wysbegeerte, 30(3). . (2012) 'What is Ubuntu? Different Interpretations among South Africans of African Descent', South African Journal of Philosophy. Philosophical Society for Southern Africa, 31(3), pp. 484-503.

GAltung, J. (1996) Peace by peaceful means: peace and conflict, development and civilization. Thousand Oaks Calif.: International Peace Research Institute.

GALTUNG, J. AND FISCHER, D. (2013) Johan Galtung: pioneer of peace research. Heidelberg; Dordrecht: Springer.

GAUNT, S. AND KAY, S. (1999) The troubadours : an introduction. Cambridge: Cambridge University Press. Available at: https://www.worldcat.org/title/troubadours-anintroduction/oclc/883719705\&referer=brief_results (Accessed: 12 August 2019).

GIDDENS, A. (1991) As Consequências da modernidade. São Paulo: Unesp.

GILLIGAN, C. (1993) In a different voice: psychological theory and women's development. Cambridge, Massachussetts: Harvard University Press.

GILPIN, R. AND GILPIN, J. M. (2001) Global political economy: understanding the international economic order. Princeton University Press.

GORDON, L.R. (2006) Disciplinary decadence: living thought in trying times. London: Routledge. 
GROTIUS, H. AND CAMPBELL, A. C. (2017) On the law of war and peace. Altenmünster: Jazzybee Verlag.

GRZYBOwSKI, C. (2019) Biocivilization. In Kothari, A. et al. (2019) Pluriverse: a postdevelopment dictionary. Delhi, India. Tulika Books.

HAAS, M. (2014) International human rights: a comprehensive introduction. New York: Routledge.

HACKe, C. AND PUGLIERIN, J. (2007) 'John H. Herz: Balancing Utopia and Reality', in International Relations. 21(3), pp. 367-382. Sage Publications. London, England. Available at: http://journals.sagepub.com/doi/10.1177/0047117807080218.

HAINES, M. (2019) 'The Population of Europe: The Demographic Transition and After', Encyclopedia of European Social History. Available at: https://www.encyclopedia.com/international/encyclopedias-almanacs-transcripts-andmaps/population-europe-demographic-transition-and-after (Accessed: 20 August 2019).

HALPERIN, D. M. (2019) 'Queer Love', Critical Inquiry. University of Chicago PressChicago, IL, 45(2), pp. 396-419.

HART, T., NELSON, P. L. AND PUHAKKA, K. (2000) Transpersonal knowing : exploring the horizon of consciousness. Albany N.Y.: State University of New York Press.

HATHAWAY, M. AND BOFF, L. (2009) The Tao of liberation: exploring the ecology of transformation. Maryknoll N.Y.: Orbis Books.

HELD, D. AND MCGREW, A. G. (2003) The global transformations reader : an introduction to the globalization debate. Cambridge: Polity Press.

HERZ, J. H. (1950) 'Idealist Internationalism and the Security Dilemma', World Politics, 2(02), pp. 157-180. Available at: http://www.journals.cambridge.org/abstract_S0043887100000253. HOOKS, bell (2010) Teaching critical thinking : practical wisdom. London: Routledge. . (1990) Ain't I a woman: Black women and feminism. London: South End Press. (2001) All about love : new visions. Perennial.

IgnAtiefF, M. (2003) 'The American Empire; The Burden', The New York Times, January. 
ILLICH, I. (1990) Tools for conviviality. New York : Marion Boyars.

. (1973) Deschooling Society. Italy: Kkien Publisher International.

INAYATUllah, N. (2011) Autobiographical international relations: I, IR. New York: Routledge.

INTERNATIONAL SOCIOLOGICAL ASSOCIATION (no date) Immanuel Wallerstein, ISA Past Presidents. Available at: https://www.isa-sociology.org/en/about-isa/history-of-isa/isapast-presidents/list-of-presidents/immanuel-wallerstein/ (Accessed: 25 February 2019).

INTERNATIONAL STUDIES ASSOCIATION (2019) About ISA. Available at: https://www.isanet.org/ISA/About-ISA/History (Accessed: 7 February 2019).

ISAIA, A. C. (2012) 'Umbanda, Intelectuais e Nacionalismo no Brasil', Fênix-Revista de História e Estudos Culturais, 9(3).

ISHAY, M. (2008) The history of human rights : from ancient times to the globalization era. Berkeley: University of California Press.

JACKSON, R. H. AND SØRENSEN, G. (2010) Introduction to international relations : theories and approaches. Oxford: Oxford University Press.

JIMÉNEZ ARENAS, J. M. AND MUÑOZ, F. A. (2012) La Paz, partera de la historia. Granada: Universidad de Granada.

JOANNA MACY (2019) Joanna Macy And Her Work. Available at: https://www.joannamacy.net/main\#work (Accessed: 5 November 2019).

KALDOR, M. (1999) New and old wars: organized violence in a global era. Stanford: Stanford University Press.

KALlER-DIETRICH, M. (2011) 'Peaces, a Gift of Grace, Turned into Modern Horror: Ivan Illich Visionary of the Twentieth Century', in DIETRICH, W. et al. (eds) The Palgrave international handbook of peace studies : a cultural perspective. New York: Palgrave Macmillan, pp. XXIX, 625.

KANT, I. (2010) Perpetual Peace: A Philosophical Sketch. Syracuse: Slought Foundation; Syracuse University Humanities Center.

KAY, C. (2008) 'Reflections on Latin American Rural Studies in the Neoliberal Globalization Period: A New Rurality?', in Development and Change, 39(6), pp. 915-943. 
KEATING, A. (2014) Anzaldua, Gloria E. (1942-2004), American National Biography. Oxford University Press. Available at: http://www.anb.org/view/10.1093/anb/9780198606697.001.0001/anb-9780198606697-e1603593 (Accessed: 12 March 2019).

KEEGAN, J. (1989) The Second World War. London: Random House.

KiRSCHEnBaum, H. (2004) 'Carl Rogers's Life and Work: An Assessment on the 100th Anniversary of His Birth' in Journal of Counseling \& Development. John Wiley \& Sons, Ltd, 82(1), pp. 116-124..

KLADI, V. M. (2009) 'Pierre Weil e o psicodrama no Brasil', in Revista Brasileira de Psicodrama. Federação Brasileira de Psicodrama, 17(1). Available at: http://pepsic.bvsalud.org/scielo.php?script=sci_arttext\&pid=S0104-53932009000100015 (Accessed: 7 February 2019).

KOPPENSTEINER, N. (2018) 'Transrational Methods of Peace Research: The Researcher as (Re)source', in Transrational Resonances. Echoes to the Many Peaces. Basingstoke: Springer International Publishing, pp. 59-81.

KOTHARI, A. ET AL. (2019) Pluriverse: a post-development dictionary. Delhi, India. Tulika Books.

KRATOCHWIL, F. V. (1991) Rules, norms, and decisions : on the conditions of practical and legal reasoning in international relations and domestic affairs. Cambridge. Cambridge University Press.

LALNILAWMA (2009) 'Rural Development Framework of an NGO', International Journal of Rural Management, 5(1), pp. 49-72. Available at: http://journals.sagepub.com/doi/10.1177/097300520900500103.

LAURELL, A. C. (2000) 'Structural Adjustment and the Globalization of Social Policy in Latin America', International Sociology, 15(2), pp. 306-325.

LEDERACH, J. P. (1995) Preparing for peace: conflict transformation across cultures. Syracuse: Syracuse University Press.

. (2005) The Moral imagination: the art and soul of building peace. Oxford [etc.] : Oxford University Press. 
. (2003) The little book of conflict transformation. Syracuse: Syracuse University.

LEDERACH, J. P. AND LEDERACH, A. J. (2010) When blood and bones cry out: journeys through the soundscape of healing and reconciliation. St Lucia: University of Queensland Press.

LENIN, V. I. (1999) Imperialism : the highest stage of capitalism. Sydney: Resistance Books.

LÉVINAS, E. (2011) Otherwise than Being, or, Beyond Essence. Pittsburgh: Duquesne University Press.

LÉVINAS, E. AND LINGIS, A. (2011) Totality and Infinity : an essay on exteriority. Pittsburgh: Duquesne University Press.

LÉVINAS, E. ET AL. (2008) Emmanuel Levinas : basic philosophical writings. Bloomington: Indiana University Press.

LINKLATER, A. (1998) The transformation of political community: ethical foundations of the Post-Westphalian era. Polity Press.

LINKLATER, A. AND LONDON SCHOOL OF ECONOMICS AND POLITICAL SCIENCE. (1990) Men and citizens in the theory of international relations. 2nd ed. Basingstoke; London: Macmillan in association with the London School of Economics and Political Science.

LOY, D. (2003) The great awakening: a Buddhist social theory. Boston: Wisdom Publications.

MACKINNON, C. A. (1987) Feminism unmodified: discourses on life and law. Cambridge Massachusetts: Harvard University Press.

MACY, J. AND YOUNG BROWN, M. (2014) Coming back to life : the updated guide to the Work that reconnects. electronic. Gabriola Island (British Columbia): New Society Publishers.

MARINUCCI, M. (2010) 'Knowledge as Kennenlernen: Subjectivity, Pluralism, and Intimacy', Social Epistemology. Routledge, 24(4), pp. 301-311.

MARTÍ I PUIG, S. (2010) 'The Emergence of Indigenous Movements in Latin America and Their Impact on the Latin American Political Scene' in Latin American Perspectives. SAGE PublicationsSage CA: Los Angeles, CA, 37(6), pp. 74-92.

MARTÍNEZ GUZMÁN, V. (2005) 'Filosofia e investigação para a paz' in Revista crítica de ciencias sociais. Centro de Estudos Sociais da Universidade de Coimbra, (71), pp. 43-62. 
. (2001) Filosofía para hacer las paces. Barcelona: Icaria.

. (1997) Kant : la paz perpetua, doscientos años después. València: Nau llibres. . (2005) Podemos hacer las paces: reflexiones éticas tras el 11-S y el 11-M. Bilbao: Desclée de Brouwer.

MASLOw, A. H. (2013) Toward a Psychology of Being. Lanham: Start Publishing LLC.

MCCRATY, R. (2015) Science of The Heart Exploring the Role of the Heart in Human Performance Volume 2. Boulder Creek: HeartMath Institute.

MEADOWS, D., RANDER, J. AND MEADOWS, D. (2014) Limits to growth: the 30-year update. White River Junction: Chelsea Green Publishing.

MEARsheimer, J. J. (2001) The Tragedy of Great Power Politics. Kindle Edi. New York London: W. W. Norton \& Company.

MENOCAL, M. R. (1985) 'Pride and Prejudice in Medieval Studies: European and Oriental' in Hispanic Review, 53(1), p. 61. doi: 10.2307/474171.

MERRILL, C. (2008) Carl Rogers and Martin Buber in Dialogue: The Meeting of Divergent Paths, The Person-Centered Journal. Springfield.

MIDGLEY, J. (1995) Social development: the developmental perspective in social welfare. London : Sage.

MIES, M. AND BENNHOLDT-THOMSEN, V. (1999) The subsistence perspective: beyond the globalised economy. New York: Zed Books.

Mignolo, W. (2011) The Darker Side of Western Modernity: Global Futures, Decolonial Options. Durham; London: Duke University Press.

. (1995) The Darker Side of the Renaissance: Literacy, Territoriality, and Colonization. Ann Arbor: University of Michigan Press.

Mohamed ALI, H. (2013) The Abject Lover of the Courtly Love Era, The Southeast Asian Journal of English Language Studies.

MOLOneY, B. (2013) Francis of Assisi and his Canticle of Brother Sun reassessed. New York: Palgrave Macmillan. 
MORGAN, W. J. AND GUILHERME, A. (2013) 'Buber and Education: Dialogue as conflict resolution. ' in Peace Review. San Francisco: Taylor and Francis, 1, p. 192.

MORgenthau, H. J. AND THOMPSON, K. W. (1997) Politics among nations : the struggle for power and peace. Beijing: Peking University Press.

MOYN, S. (2010) The last utopia : human rights in history. Cambridge Mass: Belknap Press of Harvard University Press.

MUÑOZ, F. A. 1953- (2001) La paz imperfecta. Granada: Universidad de Granada.

MUÑOZ, F. A. AND LÓPEZ MARTÍNEZ, M. (2000) Historia de la paz: tiempos, espacios y actores. Granada: Universidad de Granada.

NAESS, A. (1973) 'The shallow and the deep, long-range ecology movement. A summary' in Inquiry. Taylor \& Francis Group, 16(1-4), pp. 95-100.

NELSON, C. AND GROSSBERG, L. (1988) Marxism and the interpretation of culture. Chicago: University of Illinois Press.

NHAT Hanh, T. (1992) Peace is Every Step: The Path of Mindfulness in Everyday Life. New York: Bantan Books.

. (2004) True love: a practice for awakening the heart. Boston: Shambhala Publications.

. (2001) Anger : wisdom for cooling the flames. New York: Riverhead Books.

NOGUEIRA, J. P. AND MESSARI, N. (2005) Teoria das relações internacionais : [correntes e debates]. Rio de Janeiro: Elsevier.

NYE, J. S. AND KeOHANE, R. O. (1971) 'Transnational Relations and World Politics: An Introduction' in International Organization, 25(3), pp. 329-349. Available at: www.jstor.org/stable/2706043. (Accessed: 8 February 2019).

. (1971) 'Transnational Relations and World Politics: A Conclusion', in International Organization, 25(3), pp. 721-748. Available at: www.jstor.org/stable/2706066 (Accessed: 8 February 2019).

NYGREN, A. (1937) Agape and Eros : a study of the Christian idea of love. London: SPCK. 
ODORISIO, D. M. (2014) 'The Alchemical Heart: A Jungian Approach to the Heart Center in the Upanisads and in Eastern Christian Prayer' in International Journal of Transpersonal Studies, 33(1), pp. 27-38.

ODUOR, R. M. J. (2014) 'A Critical Review of Leonhard Praeg's A Report on Ubuntu' in Thought and Practice: A Journal of the Philosophical Association of Kenya (PAK), 6(2), pp. 75-90.

OFFICE OF THE HIGH COMMISSIONER FOR HUMAN RIGHTS (1996) Fact Sheet No.2 (Rev.1), The International Bill of Human Rights. Geneva. Available at: https://www.ohchr.org/Documents/Publications/FactSheet2Rev.1en.pdf.

ONUF, N. G. (2002) 'Institutions, Intentions and International Relations', Review of International Studies, 28(2), p. $18 . \quad$ Available at: https://www.jstor.org/stable/20097790?seq=1\#metadata_info_tab_contents (Accessed: 12 February 2019).

(2012) World of Our Making: Rules and Rule in Social Theory and International Relations. London and New York: Routledge.

OUTLAW JR., L. T. (2017) 'Africana Philosophy' in The Stanford Encyclopedia of Philosophy. Summer 201. Stanford University. Available at: https://plato.stanford.edu/archives/sum2017/entries/africana/ (Accessed: 11 March 2019). PEET, R. AND HARTWICK, E. R. (1999) Theories of development. Guilford Press.

PLUM VILLAGE (2019) Thich Nhat Hanh. Available at: https://plumvillage.org/about/thichnhat-hanh/biography/ (Accessed: 6 February 2019).

PRAEG, L. (2014) A report on Ubuntu. Scottsville: University of KwaZulu-Natal Press. PROST, A. (2014) 'War Losses', 1914-1918-online. International Encyclopedia of the First World War (WW1). Freie Universität Berlin. doi: 10.15463/ie1418.10271.

QuiJano, A. (2007) 'Coloniality and Modernity/Rationality' in Cultural Studies, 21(2-3), pp. $168-178$. Available at:

https://www.tandfonline.com/doi/full/10.1080/09502380601164353 (Accessed: 15 February 2019). 
RAMJI-NOGALES, J. (2014) 'Undocumented Migrants and the Failures of Universal Individualism' in Vanderbilt journal of transnational law, 47(3), pp. 699-763.

RICH, A. (2003) 'Notes towards a politics of location', in Lewis, R. and Mills, S. (eds) Feminist Postcolonial Theory a Reader. Edinburgh: Edinburgh University Press, pp. 2942.

RICHMOND, O. P. (2008) Peace in international relations. New York: Routledge.

ROGERS, C. R. (1977) On Personal Power: Inner Strength and its Revolutionary Impact. London: Constable.

ROSENBERG, M. (2002) 'See Me Beautiful - Live Compassionately Album'. The Center For Nonviolent Communication.

. (2005) Nonviolent communication : a language of life. 2nd edition. Encinitas California: PuddleDancer Press.

SACHS, W. (2010) The development dictionary : a guide to knowledge as power. London: Zed Books.

SAID, E. W. (1979) Orientalism. New York: Vintage Books.

SAINT AUGUSTINE (2002) The Confessions of Saint Augustine. Available at: https://www.gutenberg.org/files/3296/3296-h/3296-h.htm (Accessed: 6 February 2019).

SAKYONG MIPHAM (2012) How Society Thinks About Itself Does Matter. http://www.sakyongmedia.com. Available at: https://youtu.be/zXaBWdJrsJk (Accessed: 11 March 2019).

SANTOS, B. DE S. (2013) Se Deus fosse um ativista dos direitos humanos. São Paulo: Cortez Editora.

. (2016) Epistemologies of the South: justice against epistemicide. London: Routledge.

SARDAR, Z. (1999) 'Development and the Location of Eurocentrism', in Munck, R. and O'Hearn, D. (eds) Critical development theory : contributions to a new paradigm. New York: Zed, p. 217.

SCHOuten, P. (2012) Theory Talk \#49: John Mearsheimer on Power as the Currency of International Relations, Disciplining US Foreign Policy, and Being an Independent 
Variable,

Talks.

Available

at:

https://dl.dropboxusercontent.com/u/30572320/Theory

Talks/Talks-pdf/Theory

Talk49_Mearsheimer.pdf(Accessed: 8 February 2019). . (2009) Theory Talk \#37: Robert Cox on World Orders, Historical Change, and the Purpose of Theory in International Relations., Theory Talks. Available at: http://www.theorytalks.org/2010/03/theory-talk-37.html (Accessed: 8 February 2019).

. (2015) Theory Talk \#70: 'Nicholas Onuf on the Evolution of Social Constructivism, Turns in IR, and a Discipline of Our Making, Theory Talks. Available at: http://www.theory-talks.org/2015/07/theory-talk-70.html (Accessed: 12 February 2019).

SEN, A. (2004) 'Foreword', in Fukuda-Parr, S., Shiva Kumar, A. K., and United Nations Development Programme. Human Development Report Office. (eds) Readings in Human Development : concepts, measures and policies for a development paradigm. 2nd ed. New York: Oxford University Press, p. 395.

SESSIONS, G. (1995) Deep ecology for the twenty-first century. Boston: Shambhala. Shields, C. (2016) 'Aristotle', The Stanford Encyclopedia of Philosophy. Winter 201. Metaphysics Research Lab, Stanford University. Available at: https://plato.stanford.edu/entries/aristotle/.

SHIVA, V. (1997) 'Feminist ecology is the answer', Herizons 11 (4).

SINGER, J. D. (1961) 'The Level-of-Analysis Problem in International Relations', World Politics. Cambridge University Press, 14(01), pp. 77-92. Available at: http://www.journals.cambridge.org/abstract_S0043887100010303 (Accessed: 7 February 2019).

. (1961) 'From Deterrence to Disarmament', International Journal, 16(4), p. 307.

Available at: http://www.jstor.org/stable/10.2307/40198748?origin=crossref.

SINNIGE, T. G. (1995) 'Cornelia Johanna De Vogel (1905-1986)', A History of Women Philosophers: Volume IV: Contemporary Women Philosophers. Edited by M. E. Waithe. Dordrecht: Springer Netherlands.

SMith, A., CANNAN, E. AND STIGLER, G. J. (George J. (1976) An inquiry into the nature and causes of the wealth of nations. Chicago: University of Chicago Press. 
SOROKIN, P. A. (1954). The Ways and power of love, types, factors and techniques of moral transformation. Boston, Beacon Press.

SPIElmanN, J. (2014) 'What is TCI?', in Schneider-Landolf, M., Spielmann, J., and Zitterbarth, W. (eds) Handbook of Theme-Centered Interaction (TCI). Göttingen: Vandenhoeck \& Ruprecht, pp. 14-15.

SYLVESTER, C. (1994) Feminist theory and international relations in a postmodern era. Cambridge: Cambridge University Press.

. (2002) Feminist international relations : an unfinished journey. Cambridge:

Cambridge University Press.

TAO OF LiBERATION (2009) About Mark Hathaway and Leonardo Boff. Available at: http://www.taoofliberation.com/authors.html (Accessed: 11 March 2019).

THE CENTER FOR NONVIOLENT COMMUNICATION (2019) What is Nonviolent Communication? Available at: https://www.cnvc.org/learn-nvc/what-is-nvc (Accessed: 6 February 2019).

THE CORRELATES OF WAR PROJECT (2019) History. Available at: http://www.correlatesofwar.org/history (Accessed: 7 February 2019).

THE GREEN INTERVIEW (2009) Vandana Shiva Against Genetically-Modified Foods. Available at: https://thegreeninterview.com/interview/shiva-vandana/ (Accessed: 5 March 2019).

THE HAMPTON JOHN PETERS HUMPHREY FOUNDATION (no date) Biography John Peters Humphrey: Father of the Modern Human Rights System. Available at: http://www.humphreyhampton.org/biography.html (Accessed: 5 March 2019).

THE RUTH COHN INSTITUTE FOR TCI - INTERNATIONAL (2020) History of TCI. Available at: https://www.ruth-cohn-institute.org/history-of-tci.html (Accessed: 13 August 2020).

THE SCHOOL OF LIFE (2019) Political Theory: John Rawls, The Book of Life.

THE UNITED NATIONS ENTITY FOR GENDER EQUALITY AND THE EMPOWERMENT OF WOMEN (2019) Convention on the Elimination of All Forms of Discrimination against Women. Available at: http://www.un.org/womenwatch/daw/cedaw/ (Accessed: 11 March 2019). THUCYDIDES. (2007) The History of the Peloponnesian War. Eastbourne: Gardners Books. 
TICKNER, J. A. (1997) 'You Just Don't Understand: Troubled Engagements between Feminists and IR Theorists', International Studies Quarterly, 41(4), pp. 611-632. Available at: https://www.jstor.org/stable/2600855?seq=1\#metadata_info_tab_contents (Accessed: 12 February 2019).

TORTOSA BlASCO, J. M. (1995) 'Pasión Por La Paz - Entrevista con Johan Galtung', Revista internacional de filosofía política. Universidad Nacional de Educación a Distancia. Departamento de Filosofía y Filosofía Moral, (5), pp. 153-168.

TRUMAn, H. S. (1999) Inaugural Address, The American Presidency Project. Edited by J. T. Woolley. Santa Barbara: University of California. Available at: https://www.presidency.ucsb.edu/documents/inaugural-address-4 (Accessed: 25 February 2019).

TRUNGPA, c. (2001) Crazy wisdom. 1. ed. Boston: Shambhala.

TRUNGPA, c., BAKER, j. and CASPER, m. (2002) Cutting through spiritual materialism. Boston: Shambhala.

UNESCO (1949) Human rights: Comments and interpretations: a symposium. Edited by United Nations Educational Scientific and Cultural Organization. Paris.

UNESCO CHAIR FOR PEACE STUDIES (2014) Elicitive Conflict Mapping Online. Available at: https://www.uibk.ac.at/peacestudies/research/ecm/introduction/ (Accessed: 7 February 2019).

UNITED NATIONS (1945) Charter of the United Nations. San Francisco. Available at: https://www.refworld.org/docid/3ae6b3930.html (Accessed: 5 March 2019).

(1973) Report of the United Nations Conference on the Human Environment.

New York. Available at: https://documents-dds-
ny.un.org/doc/UNDOC/GEN/NL7/300/05/img/NL730005.pdf?OpenElement.

(2019) History of the Document. Available at: http://www.un.org/en/sections/universal-declaration/history-document/ (Accessed: 5 March 2019).

UNITED NATIONS DEVELOMENT PROGRAM (no date) Millennium Development Goals. Available at: https://www.undp.org/content/undp/en/home/sdgoverview/mdg_goals.html (Accessed: 25 February 2019). 
. (no date) About Human Development What is human development? Available at: http://hdr.undp.org/en/humandev (Accessed: 25 February 2019).

UNITED NATIONS ECONOMIC AND SOCIAL COUNCIL (1948) Union of Soviet Socialist Republics: Substitute for New Article of the Draft International Declaration on Human Rights (E/CN.4/135). Available at:

http://www.un.org/en/ga/search/view_doc.asp?symbol=E/CN.4/135.

UNITED NATIONS GENERAL ASSEMBLy (1950) Draft International Covenant on Humans Rights and Measures of Implementation: Future Work of the Commission on Human Rights (Resolution $421-V$ Section E). New York. Available at: https://documents-ddsny.un.org/doc/RESOLUTION/GEN/NR0/060/19/IMG/NR006019.pdf?OpenElement.

UNITED NATIONS GENERAL ASSEMBLY (2004) 'Report of the Committee on the Elimination of Discrimination against Women', Fifty-nint.

UNITED NATIONS HUMAN RIGHTS COUNCIL (2019) Brief historic overview of the Commission on Human Rights, Human Rights Commission Archives. Available at: https://www.ohchr.org/EN/HRBodies/CHR/Pages/Background.aspx (Accessed: 5 March 2019).

VASAK, K. (1977) 'A 30-year struggle The sustained efforts to give force of law to the Universal Declaration of Human Rights', The UNESCO Courier, November, p. 35.

VASAK, K. AND ALSTON, P. (1982) The International dimensions of human rights. Paris: Greenwood Press. Available at: https://unesdoc.unesco.org/ark:/48223/pf0000056230.

VAtTimo, G., ROVATTI, P. A. AND CARRAVetTA, P. (2012) Weak Thought. Albany: State University of New York Press.

VOLKAN, V.D. (2014) Psychoanalysis, International Relations, and Diplomacy: a Sourcebook on Large-Group Psychology. London: Karnac Books.

WALKER, R. B. J. (1993) Inside/outside: international relations as political theory. Cambridge University Press.

- (1999) 'The Hierarchicalization of Political Community', Review of International Studies, 25(1), pp. 151-156. Available at: https://www-jstororg.proxy1.lib.uwo.ca/stable/20097583?pqorigsite=summon\&seq=1\#metadata_info_tab_contents (Accessed: 8 February 2019). 
WALlersteIN, I. M. (1979) The capitalist world-economy. Cambridge: Cambridge University Press.

WALTZ, K. N. (2001) Man, the state, and war: a theoretical analysis. New York: Columbia University Press.

WEBBER, J. (2018) Rethinking existentialism, Rethinking Existentialism. Oxford: Oxford University Press. doi: 10.1093/oso/9780198735908.001.0001.

WEIL, P. (no date) Pierre Weil Biographic Summary - Preparation of the Peace educator. Available at: http://pierreweil.pro.br/1/Bio-12-USA.htm (Accessed: 12 March 2019).

WEIL, P. AND UNESCO (1994) The art of living in peace: towards a new peace consciousness. Findhorn: Findhorn Press.

WENAR, L. (2017) 'John Rawls', The Stanford Encyclopedia of Philosophy. Spring 201.

Stanford University. Available at:

https://plato.stanford.edu/archives/spr2017/entries/rawls/ (Accessed: 11 March 2019).

WENDT, A. (1992) 'Anarchy is what States Make of it: The Social Construction of Power Politics', International Organization, 46(2), pp. 391-425. Available at: https://www.jstor.org/stable/2706858?seq=1\#metadata_info_tab_contents (Accessed: 12 February 2019).

WIGHT, M. et al. (1996) International theory: the three traditions. Leicester University Press.

WILBER, K. (1995) Sex, ecology, spirituality: the spirit of evolution. Boston; London: Shambhala.Wisdom Publications (2019) David R. Loy. Available at: https://www.wisdompubs.org/author/david-r-loy (Accessed: 11 March 2019).

Woodhouse, T. (2006) 'Obituary: Adam Curle | World news | The Guardian', The Guardian, 4 October, p. 1. Available at: https://www.theguardian.com/news/2006/oct/04/guardianobituaries.religion. . (2010) 'Adam Curle: Conciliador radical y precursor dels estudis per la pau', Journal of Conflictology. Journal of Conflictology, 1(1).

WOODHOUSE, T. AND LEDERACH, J. P. (2017) Adam Curle: radical peacemaker. Stroud: Hawthorn Press. 
WORLD COMMISSION ON ENVIRONMENT AND DEVELOPMENT. (1987) Our common future. Edited by V. Hauff. Oxford University Press. 